\title{
Fragmentation of information procurement
}

\section{from large-area forest inventory and the link to the international forest regime-complex}

\author{
DISSERTATION \\ to attain the doctoral degree (Ph.D.) \\ of the Faculty of Forest Sciences and Forest Ecology \\ Georg-August-Universität Göttingen
}

submitted by

Almut Niebuhr

born on 31.08.1985 in Hoya

Göttingen, November, 2018 
Disclaimer: The views and opinions expressed herein are those of the author and do not necessarily reflect the official policy or position of any institution. Examples of analysis performed within this thesis are only examples. They should not be utilized in real-world analytic products as they are based only on very limited and dated open source information. Assumptions made within the analysis are not reflective of the position of any government entity.

1. Supervisor, Referee and Examiner:

2. Referee and Examiner

3. Examiner
Prof. Dr. Christoph Kleinn

Prof. Dr. Max Krott

Prof. Dr. Georg Winkel

Date of oral examination: $\quad$ 07.11.2018 
"Politics is a battle of ideas; in the course of a healthy debate, we'll prioritize different goals, and the different means of reaching them. But without some common baseline of facts; without a willingness to admit new information, and concede that your opponent is making a fair point, and that science and reason matter, we'll keep talking past each other, making common ground and compromise impossible."

(Barack Hussein Obama II, $44^{\text {th }}$ President of the United States, farewell address January 11, 2017 Chicago) 


\section{Acknowledgements}

This thesis would not have been possible without some special people that have crossed my way during the course of working and writing this thesis:

First of all, I would like to thank my supervisor Prof. Dr. Christoph Kleinn from the Chair of Forest Inventory and Remote Sensing for his inexhaustible support over so many years, his gentle guidance and for sharing his tremendous knowledge with me. He granted me the special opportunity to study in an inspiring and fruitful environment and incited my enthusiasm for the opportunities provided by forest inventory and monitoring.

I would also like to extend my deepest thanks to my second supervisor Prof. Dr. Max Krott from the Chair of Chair of Forest and Nature Conservation Policy for providing this opportunity and for offering his limited time and his indispensable knowledge for an extensive review. Together with Prof. Dr. Christoph Kleinn he was essentially involved in scoping the research idea and placing it on a profound fundament trough finalizing the enormous task of project proposal preparation and funding acquisition with DFG. He framed the background idea of this thesis and set the question of forest information in the political context.

Special thanks also go to my third examiner, Prof. Dr. Georg Winkel from the European Forest Institute in Bonn. He was the leader of a sister project of this thesis and his academic work has inspired many parts of this thesis. Not least for this reason I am very grateful that, despite his tight schedule as Head of the EFI Bonn Office and Resilience Programme, he found the time to travel to Göttingen and to serve as examiner during this thesis' disputation.

I am also thankful to Dr. Lukas Giessen from the Chair of Chair of Forest and Nature Conservation Policy at the University of Göttingen, for inspiring talks and our joint field research throughout the beginning of research. Through these discussions and travels he helped me a lot to better understand the world of political science.

I also owe gratitude to Dr. Douglas Evans from the European Topic Centre on Biological Diversity, to Friedrich Schmitz from BMEL and to Dr. Frank Vassen from the EC DG Environment for reading and improving the last chapter of my thesis. Their contributions were essential and their dedication to improving my work through reading and commenting was more than what I could have expected. 
Special thanks for providing support through information, advice or ideas also go to Dr. Sebastian Schnell and Dr. Sven Adler from SLU, to Dr. Axel Buschmann from BfN, Dr. Brad Smith from USDA Forest Service, Dorota Radziwiłł from GIOS Poland, Dr. Roman Michalak from FAO and many others.

I also wish to thank my colleagues and friends at the Chair of Forest Inventory and Remote Sensing for spending such valuable and formative years with me: Dr. Lutz Fehrmann, Dr. Hans Fuchs, M.Sc.Yanti Sarodja, Dr. Dian Melati, Dr. Henning Aberle, M.Sc. Collins B. Kukunda, Dr. César Pérez Cruzado, Dr. Haijun Yang, Dr. Philip Beckschäfer, Dr. Nils Nölke, M.Sc. Dengkui Mo, Dr. Philip Mundhenk, Dr. Rainer Schulz, Dr. Dominik Seidel, Dr. Xiaolu Tang, M.Sc. Ramon Trucios-Caciano, Dr. Mauricio Vega-Araya, M.Sc. Wanda Graf, M.Sc. Edwine Setia Purnama, M.Sc. Kira Urban, M.Sc. Sabine Schreiner and Silvia Wagner.

My warmest thanks go to Suman for his trust in me and his inexhaustible encouragement. You showed honest interest and never got tired of reviewing the language of yet another chapter of my thesis. You are a source of inspiration and I wish to thank you for that!

My heartfelt thanks go to my parents whose love and trust is endless. You are always there in everything I do. 
This research was mainly funded through Deutsche Forschungsgemeinschaft (DFG). The study was conducted as a subproject of the joint research project "Fragmentation of the international forest regime-complex" (PAK 813). 


\section{Summary}

If preserved and managed wisely, forests have the potential to be extremely diverse and valuable ecosystems that generate a multitude of benefits for a healthy global climate, the environment and human livelihoods. It is, in the end, such multitude of ecosystem services that have made forests an important component of a new "green economy" that markets the ecological capital of forests on global food-, timber- and carbon markets and turns them to economic assets. It is not least for that reason why today, it is generally understood that forest ecosystems have to be preserved through forest policies that effectively regulate forest management. Only then, the ecological and economic benefits of forests can be preserved such as to guarantee sustained provision for today and for future generations. Yet, for the purpose of making such important decisions, forest policy-makers need reliable scientific information. The UN Conventions on the topics of biodiversity (CBD), climate change (UNFCCC), degradation (UNCCD) and air pollution (CLRTAP), and the reporting obligations they impose on member states mirror that requirement. Yet, many benefits provided by forests are difficult to measure, not least because they are connoted by socioeconomic backgrounds and charged by ideologies. From a purely scientific perspective, i.e. neutral and void from ideologies or social values, they are therefore difficult to assess and interpret. This relates specifically to assets provided by biodiversity such as genetic resources, scenic beauty or abstract knowledge intrinsic to biotic systems that may be used in sciences such as biotechnology and pharmacy. Such values have to be defined and defended by representatives of public interests, i.e. by elected politicians and their respective administrative bodies. The first objective of this study is to identify such components of biodiversity that are relevant for policy-makers.

For this purpose, this thesis analyses biodiversity reporting processes and their data requirements at three different jurisdictional levels: Ranging from (1) Global (UN-CBD) to (2) European (EC-Habitats Directive) and (3) national reporting processes. To identify national data requirements, the study further analyses data sources that national authorities deemed to be relevant for meeting the aforementioned EU- and UN obligations. The analysis looks at three case-study countries: Germany, Poland and Sweden. However, language barriers meant that the Polish case-study remained restricted towards the analysis of UN reports. The 2010 parliamentary discourse on the amendment of the German forest act is further taken as a case-study for the relevance of forest information in political discourse and decision-making. An outlook eventually proposes ideas or starting points for future research 
such as to improve the quantification of variables that are difficult to measure and to report more comprehensively to the political aspects of biodiversity as an integral part of "sustainable forest management".

Even though this thesis regards the provision of policy relevant information as a scientific responsibility, it also has to be recognized that the involvement in the political arena of policy-making may imply certain risks for scientists. As Guldin (2003) note, the involvement of scientists in political questions may create perceptions of advocacy and thus poses a risk to scientific credibility. Some authors have even introduced the notion of the "politicization of science" (Krott, 2012; Krott et al., 2014; Pregernig, 2007) where information generation and selection is inherently biased towards hot topics of political interest (Hellström, 2000 quoted by Janse, 2008). The assumption is that policy-makers accept biased information to support sub-optimal decisions that are in the interest of a selective group of powerful stakeholders, but to the disadvantage of the majority (Krott, 2012, 2013). In the face of continued forest destruction and the inability of stakeholders to combat such destruction by compromise and an international forest convention, some authors, even speak of a "fragmented", "politically wanted", "ineffective" or "failed" forest "regime-complex "(Humphreys, 2006, 2009; Chaytor, 2001; Dimitrov, 2005; Dimitrov et al., 2007; Rayner et al., 2010). Such a "fragmented" regime-complex is, as some argue, supported by the selective use, manipulation or intentional ignorance of scientific evidence (Hertin et al., 2009; Krott, 2012; Pregernig, 2007).

This thesis argues that when attributing political bias to either side of the policy-science interface, it is important to make a clear distinction between the responsibilities of "science" and "policy-making". It is argued that either science or policy-makers may be perceived as politically biased only, when they undermine democratic systems by violating two basic principles that justify the existence of science and policy-making respectively. For scientists that primary principle is "transparency", i.e. verifiability, of information generation processes through the scientific community. For policy makers the primary principle is "transparency" of the decision-making process itself. These assumptions base on Krott's (2012) theory of "unverified information", which assumes that "unverified information", i.e. information that is neither verifiable nor transparent, allows political motivations to skew or bias results towards a politically favored result.

Based on that theoretical concept the second objective of this thesis is to make scientists aware of the risks of political bias within data provision- and decision making processes, and to provide recommendations as how to avoid such risks. For analytic purposes, "risk of 
political bias" was identified by verifying two assumptions: (1) "political motivations" (i.e. political objectives that could motivate stakeholders to come to biased results) and (2) "nontransparency" of data acquisition or decision making processes (i.e. processes that allows political objectives to tacitly bias results). These assumptions are identified in 3 case studies where each is illustrative for different stages of the science-policy interface, ranging from scientific data generation to political decision-making: (1) the 2010 parliamentary discourse on the amendment in the national forest act of Germany represents a national case study on risks of bias in political responsibilities of decision-making. Subsequently, two following case studies represent scientific responsibilities of monitoring and reporting forest status from (2) the national level under reporting obligations of the EC Habitats Directive, to (3) the international level under reporting obligations under the United Nations CBD.

Results on the parliamentary process eventually showed that policy makers tended to select and interpreted information such that they supported either utilitarian or environmentalist objectives, depending on party-membership and the interest of their respective groups of voters. However, apart from a few exceptions, the quoted evidence and conclusions made were largely transparent. Unverified information in contrast, tended to raise criticism and generally failed to convince opponents and did not contribute to consent. Then, in the second part of analysis, which looked at scientific responsibilities of data generation, the execution of such scientific tasks showed to be largely transparent. That transparency then provided little options of political interests to tacitly influence any stage of the data generation process, be it measurement, analysis or data compilation and reporting. This applied especially to assessments made by National Forest Inventories, which typically focus on forest resources that are easy to quantify (e.g. timber volume and increment) and common enough to be assessed by sampling (e.g. specific tree-species rather than species of the ground vegetation or mosses, lichen, fungi and species of fauna). Ecosystem services ${ }^{1}$ and resources provided by biodiversity $^{2}$ and (forest) ecosystems ${ }^{3}$ (as defined by CBD, 1992) in contrast were more

\footnotetext{
1 "Ecosystem services are the benefits people obtain from ecosystems. These include provisioning services such as food and water; regulating services such as flood and disease control; cultural services such as spiritual, recreational, and cultural benefits; and supporting services, such as nutrient cycling, that maintain the conditions for life on Earth." (Millennium Ecosystem Assessment, 2005)

2 "Biological diversity" means the variability among living organisms from all sources including, inter alia, terrestrial, marine and other aquatic ecosystems and the ecological complexes of which they are part; this includes diversity within species, between species and of ecosystems." (Article 2 in CBD, 1992)

3 "Ecosystem" means a dynamic complex of plant, animal and micro-organism communities and their non-living environment interacting as a functional unit." (Article 2 in CBD, 1992)
} 
difficult to measure. In such cases reporting obligations were generally vague enough to allow member states to specify those components of biodiversity that they deem to be most relevant in national or site-specific contexts. Even though national reports and the selection of respective definitions and analytic methods proved to be generally transparent, the underlying field measurements and attributes that field experts chose to select were not always completely clear. This is no problem per-se, and we may assume that results are impartial if the assessors' personal objectives were not at odds with monitoring results. However results indicated that in few cases, assessors did have responsibilities that could possibly be at odds with monitoring results. Following the argumentation of political theory, this conflict might be (mis-) perceived as a risk to scientific credibility. To address that issue, and by using the Swedish National Forest Inventory as a role model, an outlook proposes possible options of harmonising and redistributing measurement responsibilities in very specific cases such as to avoid conflict of interest and to remove any remaining ambiguity that could possibly allow such interests to steer the outcomes.

The applicability of such recommendations has, however, clear limitations. When reading this thesis and interpreting its findings, it is important to always bear in mind that conclusions drawn are based on a theoretical concept and very limited evidence to verify or measure the certainty of conclusions. The thesis thus had to rely on a few interviews, publically available reports, legal mandates and other publications, all of which are very unlikely to capture the complete picture of the political interests at stake. It is also nearly impossible to capture all the different sources of forest information used or available in forest policy contexts. Therefore, neither the conclusions on political motivations, nor those on the (non-)transparency of datause make any claim to be complete, accurate or precise. Finally, even if non-transparency of forest information had served political interests, it is impossible to confirm that stakeholders really exploited such options of steering or biasing results towards a favoured outcome. The present study therefore exclusively identifies risks, yet it does not make any claim about the (statistical) certainty of its results and conclusions. 


\section{Zusammenfassung}

Werden Wälder hinreichend geschützt und bewusst bewirtschaftet, so können sie extrem vielfältige und wertvolle Ökosysteme bereitstellen, die gleichzeitig auch eine Vielzahl von Leistungen für ein gesundes globales Klima, die Umwelt und für die Lebensgrundlage des Menschen erbringen. Letztlich sind es gerade solche Ökosystemdienstleistungen, die Wälder zu einem wichtigen Teil der neuen „grünen Ökonomie“ gemacht haben, worin globale Lebensmittel-, Holz- und Klimamärkte das ökologische Kapital der Wälder vermarkten. Auch deshalb ist heute generell bekannt, dass Waldökosysteme durch geeignete Regulierung der Waldbewirtschaftung und durch effektive Forstpolitik geschützt werden müssen. Nur so kann das ökologische und ökonomische Potential der Waldökosysteme für heutige und für zukünftige Generationen, also nachhaltig, bereitgestellt werden. Für den Zweck solcher wichtigen forstpolitischen Entscheidungen brauchen Politiker jedoch verlässliche Informationen aus der Wissenschaft. Die UN Konventionen zu den sektoralen Themen Biodiversität (CBD), Klimawandel (UNFCCC), Degradierung (UNCCD) und Luftverschmutzung (CLRTAP), sowie die Berichtspflichten, die solche Konventionen ihren Mitgliedstaaten auferlegen, sind Ausdruck dieses Informationsbedarfs. Allerdings sind viele Leistungen der Wälder nur schwer messbar, auch weil sie ideell aufgeladen sind und weil sie sozio-ökonomischen Wertvorstellungen entsprechen müssen, die nur im Kontext gesellschaftlicher Hintergründe definiert werden können. Rein wissenschaftlich, also neutral und frei von sozialen Wertvorstellungen, sind sie daher kaum messbar. Das betrifft insbesondere die Vorteile und Werte die die Biodiversität bereitstellt, beispielsweise die genetische Ressourcen, landschaftliche Schönheit oder abstraktes Wissen, das biotischen Systemen innewohnt und das möglicherweise durch technische Wissenschaften wie Biotechnologie und Pharmazie nutzbar gemacht werden kann. Solche Werte müssen über Interessenvertreter der Gesellschaft, also durch gewählte Regierungen und deren Verwaltungen herausgearbeitet und vertreten werden. Ein Ziel der vorliegenden Dissertation ist es, solch politisch relevante Komponenten der Biodiversität und deren Informationsbedarf zu identifizieren.

$\mathrm{Zu}$ diesem Zweck analysiert die vorliegende Arbeit politische Berichtsprozesse und deren Datenbedarf auf drei verschiedenen Verwaltungsebenen: Von der (1) globalen(Biodiversitätskonvention der Vereinten Nationen UN-CBD), zur (2) europäischen (FloraFauna-Habitat Richtlinie der Europäischen Gemeinschaft, EG FFH Richtlinie) bis zur (3) nationalen Ebene. Um den nationalen Informationsbedarf herauszuarbeiten, analysiert die 
Studie ferner Datenquellen, die nationale Autoritäten als relevant für die Erfüllung der oben genannten EU- und UN- Berichtspflichten erachten. Diese Analyse beinhaltet Fallstudien dreier Länder: Deutschland, Schweden und Polen. Sprachbarrieren führten allerdings dazu, dass sich die polnische Fallstudie auf die UN Berichte beschränken musste. Zudem wurde der parlamentarische Diskurs von 2010 über die Novelle des Bundeswaldgesetzes als Beispiel für die Relevanz von Waldinformationen in politischen Diskursen und Entscheidungsverfahren gewählt. Ein Ausblick eröffnet zum Abschluss denkbare Ansatzpunkte für die Wissenschaft, zur besseren Quantifizierung schwer messbarer Variablen und zur umfassenderen Berichterstattung über politische Aspekte der Biodiversität als essentiellen und integrativen Teil einer ,nachhaltigen“ Waldbewirtschaftung.

Obwohl diese Arbeit die Bereitstellung von politisch relevanten Informationen als wissenschaftliche Aufgabe betrachtet, muss dennoch beachtet werden, dass die Beteiligung an politischen Prozessen und Entscheidungen durchaus Risiken für die Wissenschaft bergen kann. So gibt Guildin (2003) zu bedenken, dass die Einbindung von Wissenschaftlern in politische Fragestellungen als politische Parteilichkeit wahrgenommen werden könnte und somit ein Risiko für die Glaubwürdigkeit der Wissenschaft darstellt. Einige Autoren sprechen sogar von der „Politisierung der Wissenschaft“ (Krott, 2012; Krott et al., 2014; Pregernig, 2007) und meinen damit einen Schaffungs- und Selektionsprozess von Informationen, der inhärent politisch voreingenommen und verzerrt ist, da er sich weitestgehend einseitig an politischen Agenden und den drängendsten Fragen der Politik ausrichtet (Hellström, 2000 zitiert von Janse, 2008). Dabei ist es allgemeine Auffassung, dass Entscheidungsträger voreingenommene und verzerrte Informationen akzeptieren, um im Interesse einzelner Akteure, sub-optimale Entscheidungen zu unterstützen, die aber zum Nachteil der Mehrheit sind (Krott, 2012, 2013). Im Lichte der fortschreitenden Waldzerstörung und der Unfähigkeit von Entscheidern, diese Zerstörung durch Kompromisse und eine harmonisierte internationale Waldkonvention zu bekämpfen, sprechen manche Autoren sogar von einem „fragmentierten“, „politisch gewollten“, „ineffektiven“ oder „verfehlten“ Wald- „Regime Komplex“ (Humphreys, 2006, 2009; Chaytor, 2001; Dimitrov, 2005; Dimitrov et al., 2007; Rayner et al., 2010). Dieser "fragmentierte" Regime-Komplex sei, so die Ansicht mancher, durch die selektive Nutzung, Manipulation oder absichtliche Ignoranz wissenschaftlicher Erkenntnisse unterstützt (Hertin et al., 2009; Krott, 2012; Pregernig, 2007).

Die vorliegende Dissertation vertritt die Ansicht, dass man bei solchen Zuschreibungen politischer Voreingenommenheit, klar zwischen den Aufgaben der „Wissenschaft“ als solcher 
und der ,politischen Entscheidungsfindung“ unterscheiden muss. Es wird argumentiert, dass für die jeweiligen Seiten im Grenzbereich von Politik und Wissenschaft nur dann ein Risiko für politische Voreingenommenheit oder Verzerrung (,risk of political bias“) besteht, wenn die jeweiligen Seiten zwei grundlegende Prinzipien untergraben, die ihre Existenz in demokratischen Systemen legitimieren. Für Wissenschaftler ist dieses grundlegende Prinzip primär die „Transparenz“, d.h. die Verifizierbarkeit des Schaffungsprozesses von Informationen durch die wissenschaftliche Gemeinschaft. Für politische Entscheider hingegen ist das primäre Prinzip die „Transparenz“ des Entscheidungsfindungsprozesses selbst. Diese Annahme basiert auf Krotts (2012) Theorie über „,nicht verifizierbare Informationen“, welche davon ausgeht, dass „nicht verifizierbare Informationen“, d.h. intransparente Informationen, politischen Interessen Vorschub geben, indem sie die Verzerrung von Ergebnissen in Richtung politisch gewollter Ergebnisse ermöglichen.

Basierend auf diesem theoretischen Konzept, ist das zweite Ziel der vorliegenden Dissertation, bei Wissenschaftlern ein Bewusstsein über solche Risiken politischer Verzerrungen (,risk of political bias“") zu wecken. Die Aufmerksamkeit gilt dabei sowohl „wissenschaftlichen“ Prozessen, wie der Bereitstellung und Generierung von Informationen, als auch politischen Aufgabenbereichen, wie der Interpretation und Entscheidungsfindung. Letztlich will die Dissertation somit auch Vorschläge für die Vermeidung entsprechender Risiken erarbeiten. Für analytische Zwecke wurde das Risiko politischer Verzerrungen durch Verifizierung zweier grundlegender Annahmen ermittelt: (1) das Vorliegen ,politischer Motivationen“ (d.h. politische Ziele, die Interessenvertreter motivieren könnten, auf Ergebnisse Einfluss zu nehmen) und (2) „Intransparenz“ der Datenakquise, bzw. der Entscheidungsprozesse (d.h. Prozesse im wissenschaftlichen, bzw. politischen Aufgabenbereich, die es ermöglichen, Ergebnisse stillschweigend entsprechend spezifischer Interessen und Ziele zu verzerren). Beide Annahmen werden jeweils anhand von 3 Fallstudien untersucht, die repräsentativ für die verschiedenen Etappen des Wissenschafts-Politik Dialogs sind, beginnend mit der „wissenschaftlichen“ Aufgabe der Datenerhebung und Bereitstellung, bis hin zur "politischen" Aufgabe der Entscheidungsfindung. (1) Dabei stellt der parlamentarische Diskurs von 2010 über die Novelle des deutschen Bundeswaldgesetzes exemplarisch eine nationale Fallstudie über die Risiken politischer Verzerrung im Aufgabenbereich der Entscheidungsfindung dar. Die beiden darauf folgenden Fallstudien beleuchten wissenschaftliche Aufgabenbereiche der Datenerhebung und Bereitstellung im Waldbereich, beginnend mit (2) den nationalen Berichtspflichten unter der EG FFH Richtlinie 
und dann überleitend $\mathrm{zu}$ den (3) internationalen Verpflichtungen unter der Biodiversitätskonvention (CBD) der Vereinten Nationen.

Im Ergebnis zeigte der parlamentarische Diskurs schließlich, dass Entscheider abhängig von Parteizugehörigkeit und den entsprechenden Interessen der jeweiligen Wählerschaft, Informationen tendenziell dahingehend selektierten und interpretierten, dass sie entweder eher utilitaristische oder umweltbezogene Ziele forcierten. Obwohl die im Parlament zitierten Nachweise und Schlussfolgerungen teilweise intransparent waren, blieben sie dennoch weitgehend transparent. Nicht verifizierbare Informationen warfen hingegen Kritik auf und waren generell nicht in der Lage, Vertreter gegenläufiger Meinungen zu überzeugen und einen Konsens herbeizuführen.

Im folgenden zweiten Ergebnisteil der Analyse, der sich mit dem wissenschaftlichen Aufgabenbereich der Datenerhebung befasste, stellte sich die Durchführung solcher "wissenschaftlichen" Aufgaben als größtenteils transparent heraus. Diese Transparenz eröffnete letztlich nur wenige Möglichkeiten zur versteckten politischen Einflussnahme auf die entsprechenden Kaskaden der Datenakquise, seien es die Messverfahren, die Analyse oder die Zusammenstellung in der Berichterstattung. Dies traf insbesondere auf nationale Waldinventuren zu, die sich generell auf Ökosystemdienstleistungen konzentrieren die leicht zu quantifizieren sind (z.B. Holzvolumen und Zuwachs) und die häufig genug sind, um in Stichprobenverfahren erfasst zu werden (z.B. bestimmte Baumarten im Gegensatz zu Arten der Bodenvegetation wie Moose oder Flechten, Pilze und Tierarten). Durch Biodiversität ${ }^{4}$ und (Wald-) Ökosysteme ${ }^{5}$ bereitgestellte Ressourcen und Ökosystemdienstleistungen ${ }^{6}$ (im Sinne der CBD-Definition) waren hingegen schwer zu messen. Daher blieben entsprechende Berichtspflichten generell so vage, dass die Mitgliedstaaten die Möglichkeit hatten, individuelle Komponenten der Biodiversität entsprechend ihrer Relevanz in den jeweiligen

\footnotetext{
${ }^{4}$ „Biologische Vielfalt [kurz Biodiversität] ist die Variabilität unter lebenden Organismen jeglicher Herkunft, darunter unter anderem Land-, Meeres- und sonstige aquatische Ökosysteme und die ökologischen Komplexe, zu denen sie gehören; dies umfasst die Vielfalt innerhalb der Arten und zwischen den Arten sowie die Vielfalt der Ökosysteme. (Übersetzung von Artikel 2 der CBD, 1992 gemäß des deutschen Übersetzung der EG Verordnung Nr.1946/2003)

5 "Ökosystem" ist eine funktionelle dynamische Einheit aus Pflanzen-, Tier- und Mikrobengemeinschaften und ihrer nicht lebenden Umwelt (Übersetzung von Artikel 2 der CBD, 1992 gemäß des deutschen Übersetzung einer Vorlage der Europäischen Kommission in: KOM(2007)605)

6 "Ökosystemdienstleistungen" beschreiben Vorteile, die Menschen aus ökologischen Systemen beziehen. Diese schließen ein: Bereitstellende Dienstleistungen wie Nahrung und Wasser; regulierende Dienstleistungen wie die Kontrolle von Überflutungen und Krankheiten; kulturelle Dienstleistungen wie spirituelle, erhohlungrelevante und kulturelle Vorteile; sowie unterstützende Dienstleistungen des Nährstoffkreislaufes, welche die Lebensbedingungen auf der Erde aufrechterhalten. (Übersetzung der Autorin von: Artikel 2 der CBD, 1992)
} 
nationalen oder lokalen Kontexten zu definieren. Obwohl sich die Selektion von Definitionen und Analysemethoden nationaler Berichte dabei im Allgemeinen als transparent herausstellte, waren in einigen Fällen, die zugrundeliegenden Inventurmethoden und Variablen, die ein Feldbiologe für seine Aufnahmen und Messungen wählte, nicht immer uneingeschränkt transparent. Das muss generell noch kein Problem sein und man könnte annehmen, dass die Ergebnisse dennoch objektiv sind, wenn man davon ausginge, dass persönliche Interessen nicht im Wiederspruch zu den erzielten Ergebnissen stünden. Jedoch deuten Ergebnisse darauf hin, dass Gutachter in einigen Fällen Aufgaben hatten, die im Konflikt mit Monitoring Ergebnissen stehen könnten. Entsprechend der oben beschriebenen Theorie aus der Politikwissenschaft, könnte dieser Konflikt unter Umständen als ein Risiko für wissenschaftliche Glaubwürdigkeit (miss-) verstanden werden. Um dieses Thema anzugehen, versucht die vorliegende Dissertation im Ausblick und am Beispiel der schwedischen Nationalen Waldinventur, denkbare Ansätze für eine mögliche Harmonisierung von Messverfahren und eine Neuausrichtung von Mandaten vorzulegen. Interessenkonflikte, zweideutige Vorgaben und das damit verbundene Risiko für verdeckte und interessengerichtete, d.h. politische Einflussnahme durch die Selektion spezifischer Methoden könnten so möglicherweise vermieden werden.

Die Anwendbarkeit solcher Vorschläge hat jedoch klare Grenzen. Bei der Lektüre dieser Dissertation und der Interpretation ihrer Ergebnisse muss stets beachtet werden, dass Vorschläge und Schlussfolgerungen auf einer theoretischen Argumentation beruhen und nur auf eine sehr begrenzte Evidenzbasis zurückgreifen konnten, bei der die Unsicherheiten in Bezug auf die Richtigkeit der erzielten Ergebnisse nicht messbar und daher unbekannt ist. So konnte sich die Dissertation ausschließlich auf wenige Interviews, öffentlich verfügbare Berichte, Gesetzestexte, Mandate und andere Publikationen zu stützen. Wobei diese Quellen aller Wahrscheinlichkeit nach nicht in der Lage gewesen sein konnten, ein allumfassendes Bild aller beteiligten politischen Interessen zu vermitteln. Zudem ist es auch schwierig, alle in politischen Kontexten verfügbaren und verwendeten Waldinformationen vollständig zu ermitteln. Daher stellen weder die Schlussfolgerungen über politische Motivationen, noch jene über die (In-)Transparenz der politischen Informationsquellen einen Anspruch auf Vollständig- oder Richtigkeit. Auch wenn Intransparenz von Waldinformationen politischen Interessen theoretisch genützt hätten, lässt sich letztendlich unmöglich feststellen, ob Interessenvertreter die Möglichkeit versteckter politischer Einflussnahme tatsächlich genutzt haben, um "wissenschaftliche" Daten in Richtung eines politisch gewollten Ergebnisses zu lenken oder zu verzerren. Die vorliegende Studie identifiziert daher ausschließlich Risiken 
und macht keine Annahmen über die (statistische) Sicherheit der erzielten Ergebnisse und Schlussfolgerungen. 


\section{Table of Contents}

Chapter 1: Introduction and Objectives - The role of forest information in an international forest policy regime

1.1 Historical overview of major forest policies and the rise of monitoring programmes on Sustainable Forest Management (SFM)

1.1.1 Early concepts of Sustainable Forest Management (SFM) and the development of

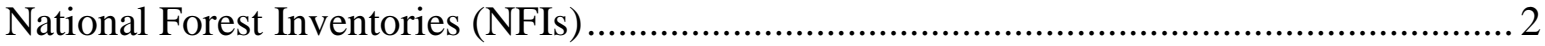

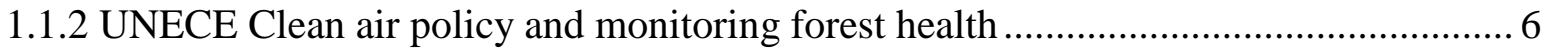

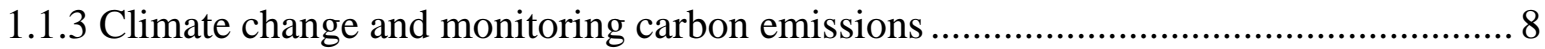

1.1.4 EC Habitats Directive and monitoring forest habitats .......................................... 10

1.1.5 The Convention on Biological Diversity and its reporting programmes.................... 12

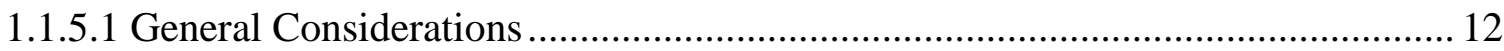

1.1.5.2 The European Biodiversity Indicator Initiative under CBD ............................... 14

1.1.5.3 The Global Biodiversity Indicator Initiative under CBD …............................... 15

1.1.6 A non-legally binding forest policy and the Pan-European Criteria and Indicator Initiative

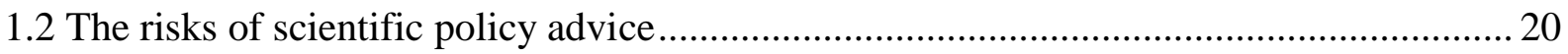

1.3 Theories on locating political bias in the science-policy-interface ................................ 23

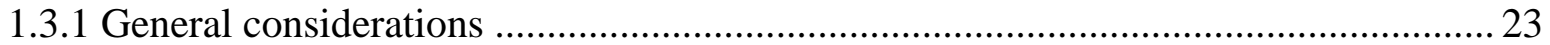

1.3.2 Gaps in democratic decision making - Political bias in the policy domain.................24

1.3.3 Gaps in scientific credibility - Political bias in the scientific domain .......................25

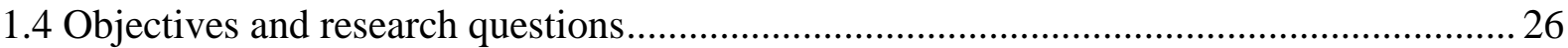

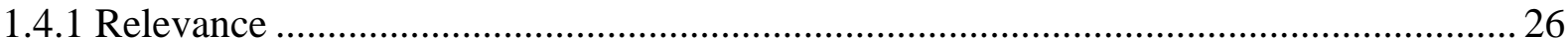

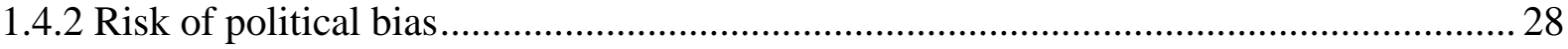

Chapter 2: Methods - Analysing information relevance and the risk of politically biased information in the international forest policy regime

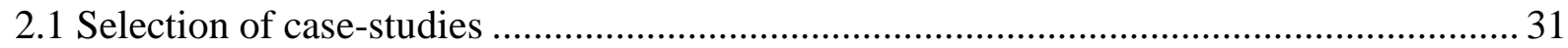

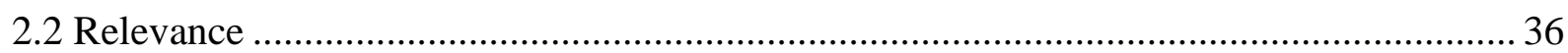


2.2.1 General considerations on measuring "relevance" and the method of guided literature research

2.2.2 Defining "data sources" and assessing political relevance of the three components:

"attributes", "quality" and "providers".

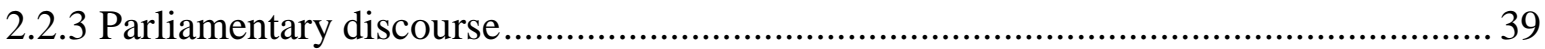

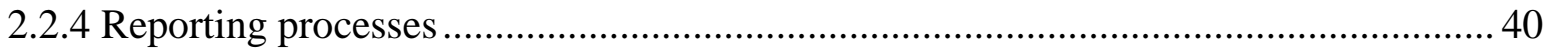

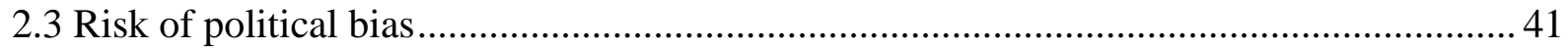

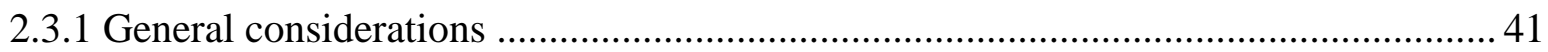

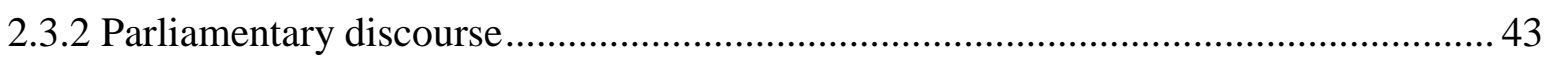

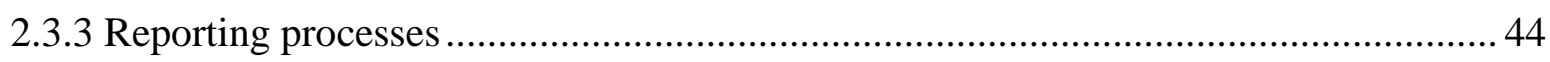

Chapter 3: Case Study - Fragmentaion in the political discourse

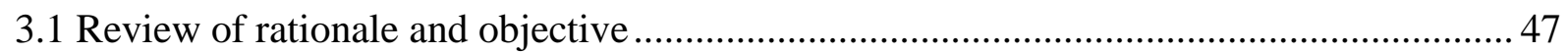

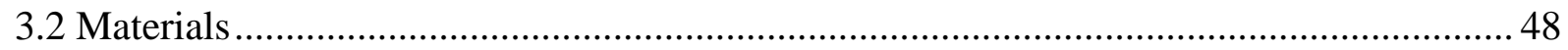

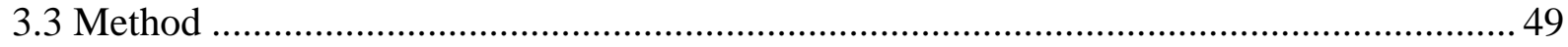

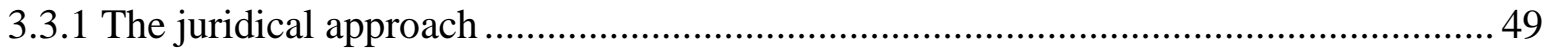

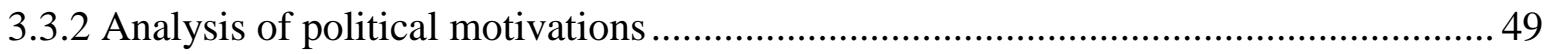

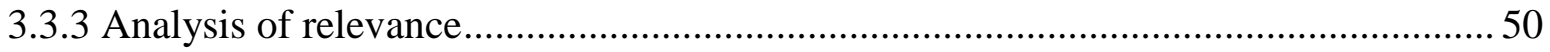

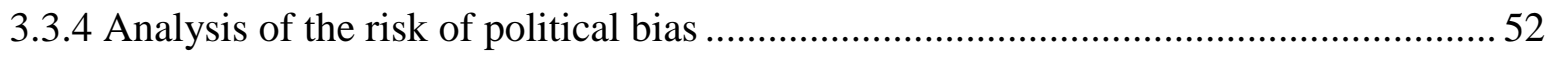

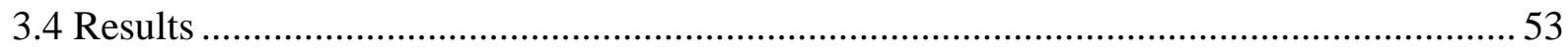

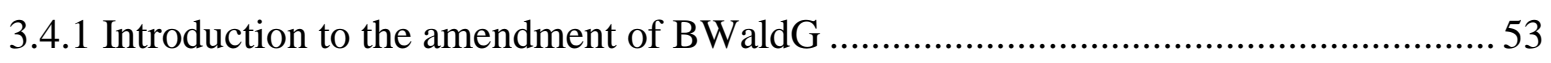

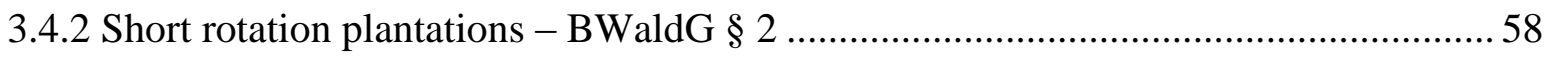

3.4.2.1 Overview of discourse history and political motivations ................................. 58

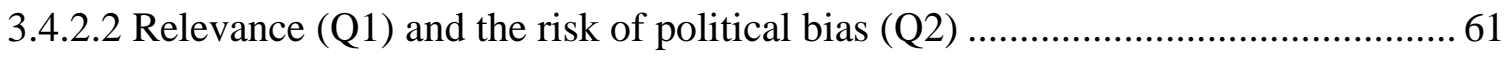

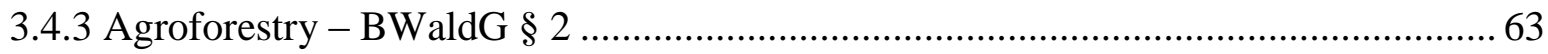

3.4.3.1 Overview of discourse history and political motivations .................................. 63

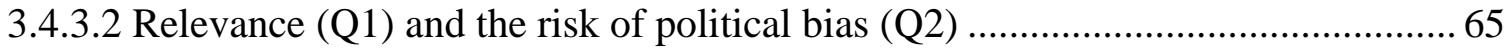

3.4.4 Harmonisation with European IACS database - BWaldG $\S 2$................................. 66

3.4.4.1 Overview of discourse history and political objectives ........................................6 66 
3.4.4.2 Relevance (Q1) and the risk of political bias (Q2)

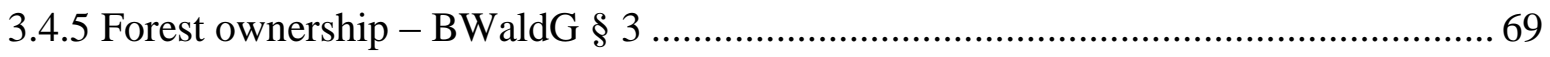

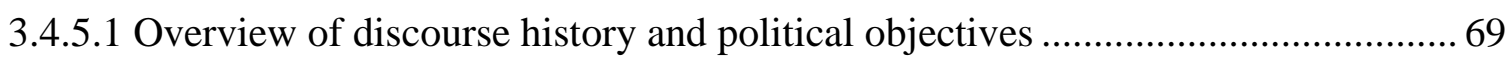

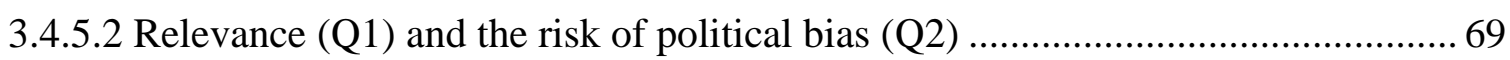

3.4.6 Economic rights of "private forestry associations" - BWaldG $\S \S 37$ and 40 ........... 71

3.4.6.1 Overview of discourse history and political objectives ................................... 71

3.4.6.2 Relevance (Q1) and the risk of political bias (Q2) .......................................... 72

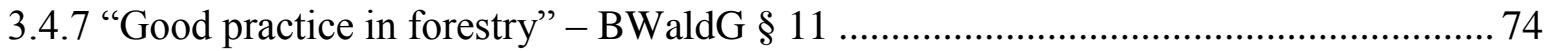

3.4.7.1 Overview of discourse history and political objectives .................................... 74

3.4.7.2 Relevance (Q1) and the risk of political bias (Q2) ......................................... 77

3.4.8 The NFI mandate and international reporting obligations- BWaldG $\S 41 \mathrm{a} \ldots \ldots \ldots \ldots \ldots . . . . . .82$

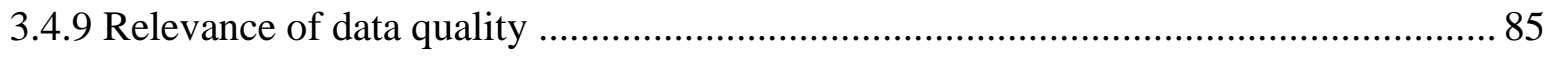

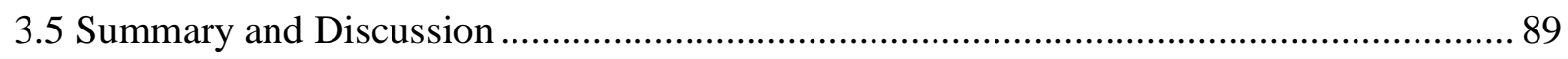

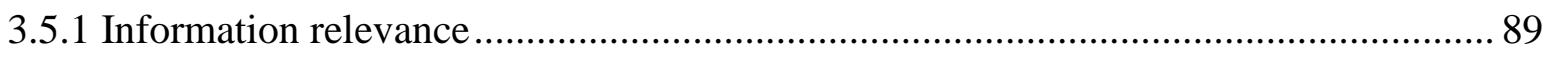

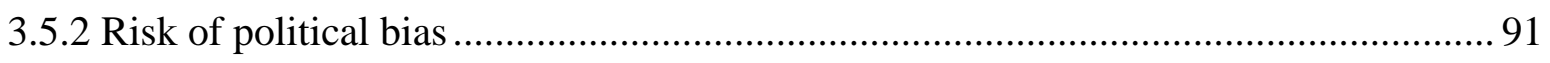

Chapter 4: Case Study - Fragmentation in national reports to the European Commission

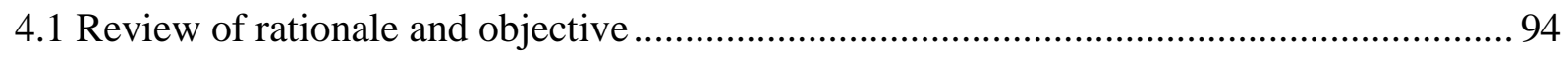

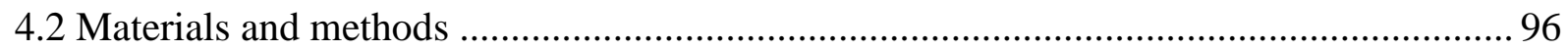

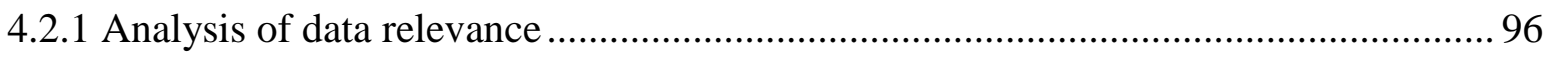

4.2.2 Analysing risk of political bias and the (non-) transparency of data......................... 99

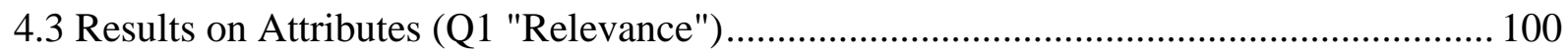

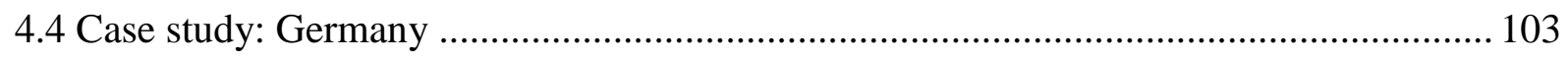

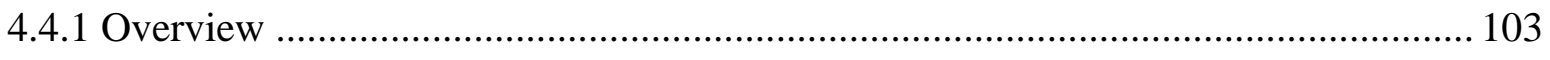

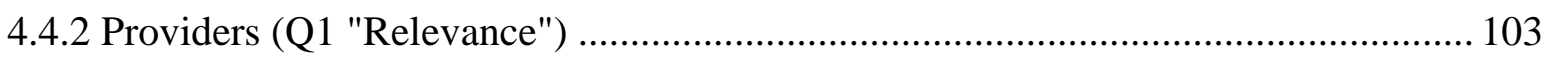

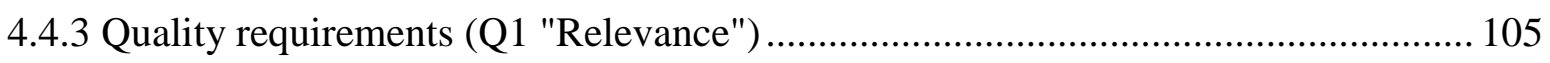

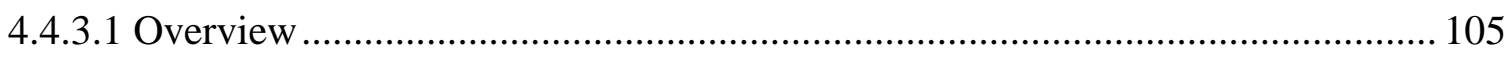

4.4.3.2 Reporting "Habitat area" and "Range" ............................................................. 105

4.4.3.3 Reporting "Specific structures and functions" ................................................. 110 


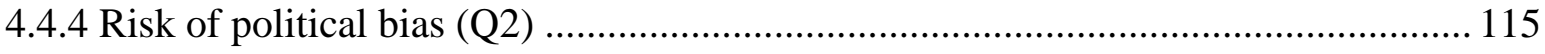

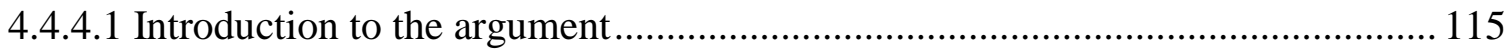

4.4.4.2 Scientific motivation and benefit of transparency ......................................... 115

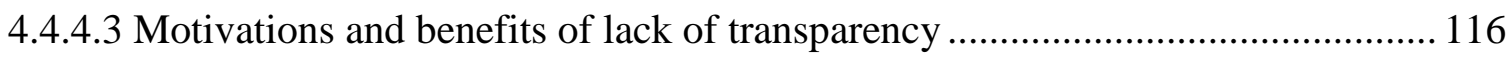

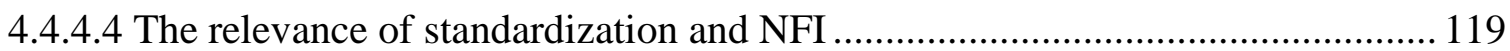

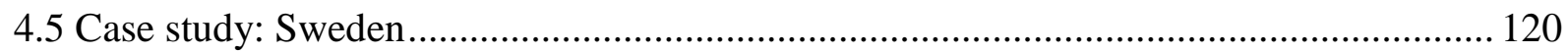

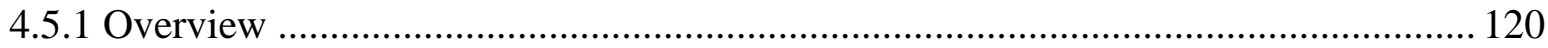

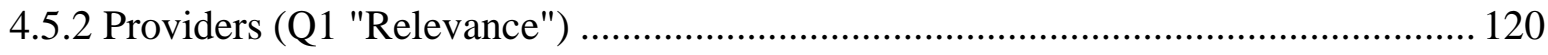

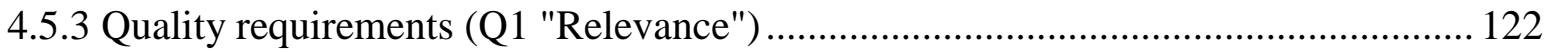

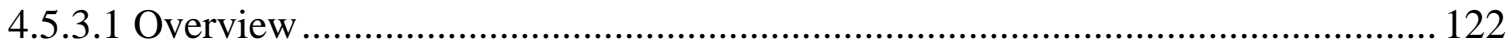

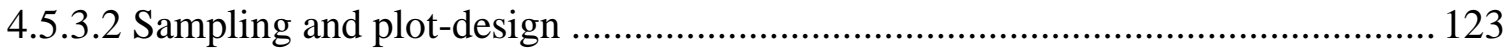

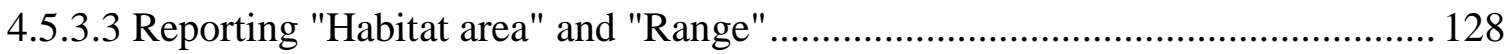

4.5.3.4 Reporting the "Conservation status"-index of "Habitat area" and "Range" ....... 130

4.5.3.5 Reporting "Threats and pressures", "Specific structures and functions", and

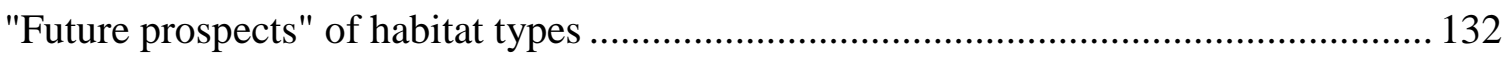

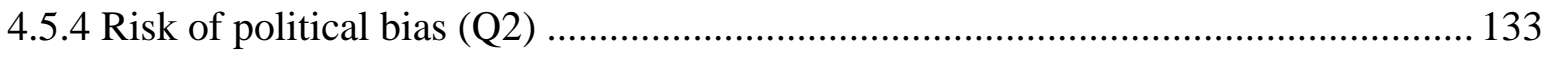

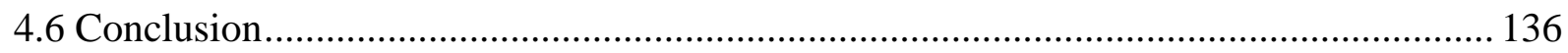

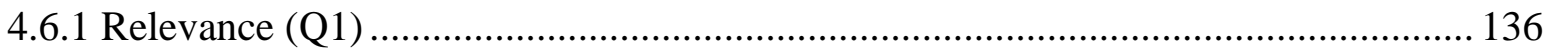

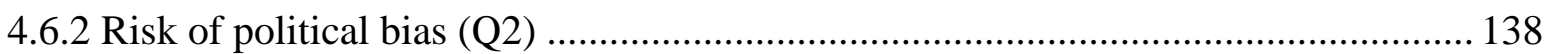

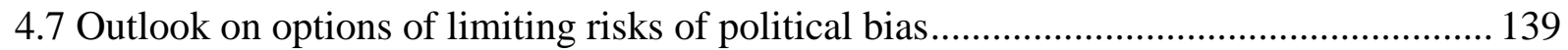

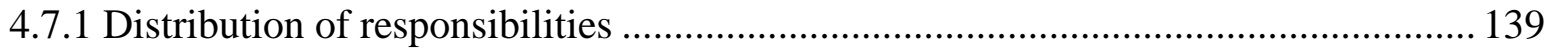

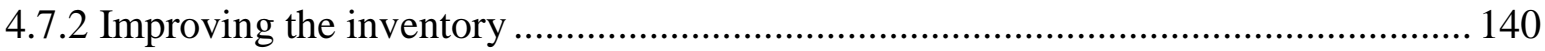

Chapter 5: Case Study - Fragmentation in EC- and UN reports to the Secretariat of the United $\underline{\text { Nations' Convention on Biological Diversity }}$

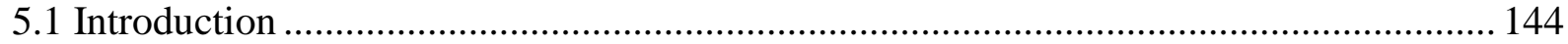

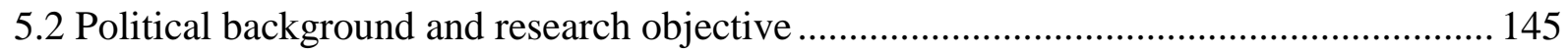

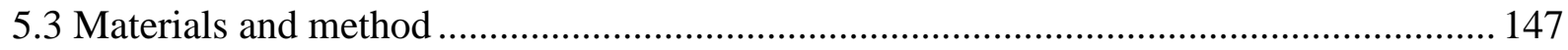


5.4.1 UN-Target 5: Reducing loss of natural habitats and forest areas

5.4.2 UN-Target 7: Sustainable forest management.

5.5 Risk of political bias (Q2)

5.6 Conclusion

5.7 Outlook on options to improving the inventory

5.7.1 Relationships and building trust

5.7.2 Inventory design

Chapter 6: Synthesis and Summary of Discussions - Improving inventories for politically $\underline{\text { relevant and scientifically credible information }}$

6.1 General considerations 166

6.2 Data requirements and options to improve inventory designs 167

6.2.1 General overview on the policy background 167

6.2.2 Assessing causal agents and threats to forest status 170

6.2.3 Assessing rare species and ecosystems 172

6.2.4 Meeting data quality standards 176

6.2.5 Streamlining inventories to meet quality requirements

6.2.6 Data presentation and communication 188

6.3 The risk of political bias and options to protect scientific credibility 193

Annex I: The 20 Aichi targets as defined by the global strategic plan for Biodiversity 20112020 (UNEP/CBD/COP decision X/2 (2010)) 202

Annex II: Indicators of the Initiative "Streamlining European Biodiversity Indicators" (SEBI)

Annex III: Pan-European Criteria and Indicators from 7th Ministerial Conference of Forest Europe in Madrid, 2015 205

Annex IV: Policy-targets on "Sustainable Forest Management" by UNFF. 207

Annex V: Criteria of Good Practice in forest management after Winkel and Volz (2003) ... 208 Annex VI: Materials for Analysis of National Reporting Processes under Habitats Directive Article 17. 
Annex VII: German data requirements when reporting under Habitats Directive.

Annex VIII: Swedish data requirements when reporting under Habitats Directive.

Literature . 


\section{List of Abbreviations}

AHTEG Ad Hoc Technical Expert Group

BBS

Breeding Bird Survey of the United Kingdom

BCE

Butterfly Conservation Europe (Non-Governmental Organization)

$\mathrm{BfN}$

Bundesamt für Naturschutz, Federal Agency for Nature Conservation

BGB1.

Bürgerliches Gesetz Blatt, German civil law gazette

$\mathrm{BImA}$

Bundesanstalt für Immobilienaufgaben, Institute for Federal Real Estate

BISE

Biodiversity Information System for Europe

BLE

Bundesanstalt für Landwirtschaft und Ernährung, German Federal Agency for Agriculture and Food

BMBF Bundesministerium für Bildung und Forschung, German Ministry for Education and Research

BMEL Bundesministerium für Ernährung und Landwirtschaft, Federal Ministry for Food (previously and Agriculture

BMELV)

BMELV Bundesministerium für Ernährung, Landwirtschaft and Verbraucherschutz, Federal (now BMEL) Ministry for Food, Agriculture and Consumer Protection

BMFG Polish Bureau for Forest Management and Geodesy, Biuro Urzadzania Lasu i Geodezji Leśnej

BMUB (now Bundesministerium für Umwelt, Naturschutz (Bau) und Reaktorsicherheit, Federal

BMU) Ministry for the Environment, Nature Conservation, (Building) and Nuclear Safety

BMWi Bundesministerium für Wirtschaft und Energie, Federal Ministry of Economics and Technology

BNatSchG Bundesnaturschutzgesetz, Federal Nature Conservation Act of Germany

BWaldG Bundeswaldgesetz, Federal Forest Act of Germany

BZE Bodenzustandserhebung, National Forest Soil Inventory (variables after manuals in: Wellbrock et al. (2006))

CAP European Common Agricultural Policy

CBD Convention on Biological Diversity

CDU/CSU Christlich Demokratische Union/Christlich Soziale Union in Bayern (coalition of conservative parties in North- and South-Germany)

cf. compare

Ch. Chapter 


\begin{tabular}{|c|c|}
\hline CLC & Corine Land Cover \\
\hline CLTRAP & Convention on Long-Range Transboundary Air Pollution \\
\hline $\mathrm{COP}$ & Conference of Parties \\
\hline COST & Cooperation in Science and Technology \\
\hline $\mathrm{CPF}$ & Collaborative Partnership on Forests \\
\hline DDA & $\begin{array}{l}\text { Dachverband Deutscher Avifaunisten, German umbrella organisation of } \\
\text { ornithologists }\end{array}$ \\
\hline $\mathrm{DE}$ & Germany \\
\hline DG Env. & Directorate General Environment of the European Commission \\
\hline DIP & $\begin{array}{l}\text { Dokumentations- und Informationssystem für Parlamentarische Vorgänge, } \\
\text { Parliamentary Material Information System }\end{array}$ \\
\hline DLR & Deutsches Zentrum für Luft und Raumfahrt, German Aerospace Center \\
\hline DNA & Deoxyribonucleic acid \\
\hline DVL & $\begin{array}{l}\text { Deutscher Verband für Landschaftspflege e.V., German Association for Landscape } \\
\text { Management }\end{array}$ \\
\hline DWD & Deutscher Wetterdienst, German Weather Service \\
\hline EBCC & European Bird Census Council \\
\hline $\mathrm{EC}$ & European Commission \\
\hline ECOSOC & United Nations Economic and Social Council \\
\hline EEA & European Environment Agency \\
\hline EIONET/ROD & European Environment Information and Observation Network with its Reporting \\
\hline & Obligations Database \\
\hline ENGO & Environmental Non-Governmental Organisation \\
\hline ERFAD & European Agricultural Fund for Rural Development \\
\hline $\mathrm{ETC} / \mathrm{BD}$ & European Topic Centre on Biological Diversity \\
\hline ETM+ & Enhanced Thematic Mapper \\
\hline EU & European Union \\
\hline FAO & Food and Agricultural Organization of the United Nations \\
\hline FDP & Freie Demokratische Partei, liberal political party in Germany \\
\hline $\mathrm{FE}$ & $\begin{array}{l}\text { Forest Europe (Ministerial Conference, political forum of European Ministers on } \\
\text { forestry) }\end{array}$ \\
\hline FRA & Forest Resource Assessment \\
\hline FSC & Forest Stewardship Council \\
\hline GBO & Global Biodiversity Outlook \\
\hline
\end{tabular}




$\begin{array}{ll}\text { GBOL } & \text { German Barcode of Life } \\ \text { GDOS } & \text { Generalna Dyrekcja Ochrony Środowiska, Polish General Directorate of } \\ & \text { Environmental Protection } \\ \text { GDP } & \text { Gross Domestic Product } \\ \text { GHG } & \text { Greenhouse gas } \\ \text { GIOS } & \text { Polish Inspectorate of Environmental Protection (Governmental Agency) } \\ \text { Grüne } & \text { The Greens (green political party in Germany) } \\ \text { HIG } & \text { University of Gävle } \\ \text { IACS } & \text { Integrated Administration and Control System database } \\ \text { iBOL } & \text { International Barcode of Life } \\ \text { ICP Forests } & \text { International Co-operative Programme on Assessment and Monitoring of Air } \\ & \text { Pollution Effects on Forests } \\ \text { IPCC } & \text { Intergovernmental Panel on Climate Change } \\ \text { IUCN } & \text { International Union of Conservation of Nature } \\ \text { JRC } & \text { Joint Research Centre }\end{array}$

LANA Länder Arbeitsgruppe Naturschutz, conference of representatives of conservation agencies

Level I European forest health inventory on a $16 \times 16$ grid of permanent sample plots (UNECE ICP Forests Programme Co-ordinating Centre, 2016)

Level II European forest health inventory on a subsample of a 16 x 16 grid of permanent sample plots, more intensive and experimental measurements (UNECE ICP Forests Programme Co-ordinating Centre, 2016)

LfU Bayerisches Landesamt für Umwelt, Bavarian Environment Agency

LIFE+ $\quad$ Financial Instrument for the Environment

Linke The Left (democratic socialist and left-wing political party in Germany)

LULUCF Land Use, Land-Use Change and Forestry

LWF Bayerische Landesanstalt für Wald und Forstwirtschaft, State Agency of Bavaria for Forestry and Silviculture

LwK Landwirtschaftskammer Niedersachsen, Lower Saxony Chamber of Agriculture M\&R Monitoring and Reporting

MCPFE Ministerial Conference on the Protection of Forests in Europe (now: Forest Europe)

MMR Monitoring Mechanism Regulation

MODIS Moderate Resolution Imaging Spectroradiometer

MOTH Demonstration of an Integrated North-European system for Monitoring Terrestrial 
Habitats

MRV Monitoring Reporting and Verification

n.d. No date

NABU Nature And Biodiversity Conservation Union (Non-Governmental Organisation)

NASA National Aeronautics and Space Administration

NDC Nationally Determined Contribution (national targets required by Paris Agreement, Article 4, paragraph 2)

NDVI Normalised Difference Vegetation Index

NFI II (2) Second National Forest Inventory (BMELV, 2000)

NFI III (3) Third National Forest Inventory (BMELV, 2014)

NGO Non-Governmental Organization

NILS National Inventory of Landscapes in Sweden

NLWKN Niedersächsischer Landesbetrieb für Wasserwirtschaft, Küsten- und Naturschutz, Lower-Saxony's Environment Agency

OTOP Ogólnopolskie Towarzystwo Ochrony Ptaków, Polish Society for the Protection of Birds

p.m. $\quad$ Printed matter, Drucksache

PEFC Programme for the Endorsement of Forest Certification schemes (Non-Governmental Organisation)

PL Poland

POP Persistent Organic Pollutant

R\&D project Research and Development project

SAR Synthetic Aperture Radar

SE Sweden

SEBI Streamlining European Biodiversity Indicators

SEPA Swedish Environmental Protection Agency

SFM Sustainable Forest Management

SK Ständortskarteringen, Swedish National Survey of Forest Soils and Vegetation

SLU Sveriges Lantbruksuniversitet, Swedish University of Agricultural Sciences

SOF Sveriges Ornitologiska Förening, Swedish Ornithological Society (SOF)

SPD Sozialdemokratische Partei Deutschlands (social-democratic political party in Germany)

SRP Short Rotation Plantation

SRU Sachverständigen Rat für Umweltfragen, German Advisory Council on the 
Environment

StMELF Bayerisches Staatsministerium für Ernährung, Landwirtschaft und Forsten, Bavarian State-Ministry of Food, Agriculture and Forestry

TI

Thünen Institut, Federal Research Institute for Rural Areas, Forestry and Fisheries

TOM Polish Association for Butterfly Conservation

UBA Umweltbundesamt, German Environment Agency

UFZ Helmholz-Zentrum für Umweltforschung, Helmholtz Centre for Environmental Research

UNCCD United Nations Convention to Combat Desertification

UNCED United Nations Conference on Environment and Development

UNECE United Nations Economic Commission for Europe

UNFCCC United Nations Framework Convention on Climate Change

UNFF United Nations Forum on Forests

VOC Volatile Organic Compounds

VwV Verwaltungsvorschrift, Administrative Regulation

WZE Waldzustandserhebung, National Forest Health Inventory (variables after manuals in: Wellbrock et al. (2006)) 


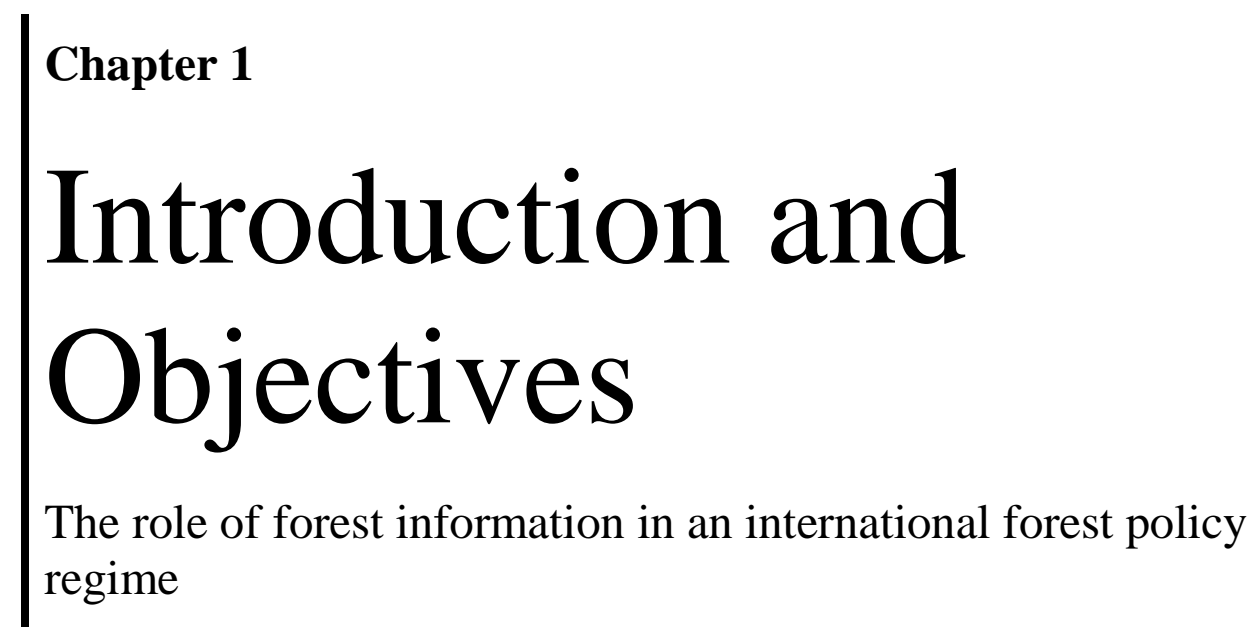




\subsection{Historical overview of major forest policies and the rise of monitoring programmes on Sustainable Forest Management (SFM)}

\subsubsection{Early concepts of Sustainable Forest Management (SFM) and the development of National Forest Inventories (NFIs)}

Worldwide, forests are an important component of ecosystems and a green economy that uses such systems as a resource to provide for human livelihoods and well-being. Not least, and in spite of different interpretations and measurements methods, most large-area estimates agree that forests cover about a third of the global mainland (cf. Hansen et al., 2013 ${ }^{7} ; 30.6 \%$ in FAO, 2016 ${ }^{8} ; 29.68 \%$ in Matthews, $1982^{9}$ ). According to FAO (2014a) statistics, such areas provide direct employment in the forestry sector (forestry and logging activities, sawnwood and wood-based panel production, pulp and paper production) for about 13.2 million people worldwide. Considering also other dependencies such as food, woodfuel for cooking and cash generated in sectors indirectly related to forestry, the FAO expects nearly 1.6 billion people, or 25 percent of the world's population, to be depended on forests for their living (FAO, 2013).

As a result, livelihoods and the state of economic development depends, to a large extent, on forest-based products and services. Let alone the direct contribution of the pulp- and paper industry, the wood and furniture industry, and forestry activities were estimated to contribute 0,9 percent to the global Gross Domestic Product (GDP) in 2011 (FAO, 2014b). This figure might seem to be low on first sight, but it would be much higher if statistics included multiplier effects in the production chain and cross-sectoral benefits. Yet, it is not only formal use within the forestry sector and its related industries (printing and publishing, energy, building and housing) that contributes to human well-being, also informal uses and benefits derived from forest resources are expected to have a large effect on livelihoods and economies (FAO, 2014a; Costanza et al., 1997; Balmford et al., 2002; Millennium Ecosystem Assessment, 2005). Examples are non-marketed subsistence-based activities and uses of nonwood forest products (e.g. food for people, fodder for animals, medicine). Also important

\footnotetext{
7 "Lands dominated by trees with a per cent canopy cover $>60 \%$ and height exceeding $5 \mathrm{~m} . "$

8 "Land spanning more than 0.5 hectares with trees higher than 5 meters and a canopy cover of more than 10 percent, or trees able to reach these thresholds in situ. It does not include land that is predominantly under agricultural or urban land use." plus explanatory notes in: FAO (2016)

${ }^{9}$ Matthews (1982) adopts UNESCO (1937) definition: "Closed Forest: Formed by trees at least $5 \mathrm{~m}$ tall with their crowns interlocking. In reproductive stage or as immature secondary growth temporarily less than $5 \mathrm{~m}$ tall, but individuals of scapose life form, i.e. real trees, no shrubs. In subpolar conditions, the limit may be only $3 \mathrm{~m}$, in tropical ones 8 or $10 \mathrm{~m} . "$
} 
ecosystem services ${ }^{10}$ such as air purification, water filtration, erosion control, mitigation of climate change and provision of genetic resources have been attributed to forests (de Groot et al., 2002; Gilbert and Janssen, 1997; Costanza et al., 1997, FAO, 2014c). Such benefits and resources are, however, difficult to estimate because they are difficult to measure and quantify in monetary terms. They are therefore often hidden from national statistics, the public eye and the agenda of global policy makers, who generally see the benefits of sustainable forest management more within the sustained production of timber-based-resources and the (measureable) increase in GDP. Assessing the large thematic range of difficult-to measure benefits therefore challenges the limits of science and of large-area resource inventories in forests.

The original idea of sustainable forest management, which later lead to multi-purpose forest inventories, is often attributed to 1713 when a German forester, Hans Carl von Carlowitz, formulated the first principles. His ideas are valid until today and have been reformulated in section 11, subsection 1 of first German forest act ( $111(1), \mathrm{BWaldG})$ : "In the framework of its purpose, forest should be managed properly and sustainably." (BGBl. I S. 1037). Yet at Carlowitz' time, the growing population was much more dependent on timber products than today, where we have a larger range of industrial materials and energy resources available. Instead, in Carlowitz' time, the expanding cities and the mining, salt and glass industries in Germany, as well as emergent trade to overseas and the growing fleet of trade ships in Holland, England and France had devoured remaining forest stocks and lead to severe shortness of wood. During his journeys Carlowitz witnessed the relentless depletion of timber stocks in European forests. He recognized that these processes will slow down economic and, eventually, human development. He was one of the first who responded to these issues and stipulated the need for better planning and regulation of forest management instead of mere exploitation. In his „Sylvicultura oeconomica", which was published in 1713 (Carlowitz, 1713), he advised foresters to replant trees and to limit harvests so as to allow them to regrow in time. He also advised the people of his time not to waste but to use timber products wisely. However, while he founded the discipline of silviculture, he did not give indications of how to monitor its sustainability.

\footnotetext{
${ }^{10}$ Ecosystem services, as defined by the Millennium Ecosystem Assessment $(2005)^{10}$, must be distinguished from more easy-to measure "environmental services" (WTO, 1998) which are provided through human activities and targeted towards the protection of ecosystems and their functioning (e.g. sewage treatment, refuse disposal, cleaning exhaust gases, nature and landscape protection).
} 
Carlowitz' ideas were influential long after his death and they have been developed and extended ever since. They lead to the establishment of training courses for foresters and the establishment of forestry as a research topic in the Universities of Tharandt near Dresden, in Eberswalde, in Freiburg and in Hannoversch Münden which is nowadays part of the University of Göttingen. In the wake of more rigorous planning of forest management in the 19th century it became clear that such planning required quantitative assessments in forests: the first stand-level inventories and maps documented the status and change of forests, of growing stocks and of structural components such as regeneration and tree species. Among the earliest of such measurements that have been documented are those of 1812 and 1817 in Saxony near Dresden (Seiler, 2012).

After the two world-wars, Germany and other countries in Europe and worldwide suffered another phase of shortness of wood. During the 1970's, the industrial boom, problems of air pollution and acid rain aggravated the situation. Especially forest degradation with defoliation and high mortality rates expanded the previously more timber-focused perspective towards environmental concerns of forest health (Sanders et al., 2016).

\section{$\S 1$ Purpose of the Act}

The purpose of this Act is

1. to conserve forests due to their economic benefits (productive function) and their importance for the environment, in particular the constant services rendered by forests, to preserve the ecosystem, for the climate, clean air, soil fertility, water supply, to sustain the landscape, agriculture, infrastructure, and the recreation of the population (protective and recreational functions), to expand them, wherever possible, and to ensure their proper management on a sustainable basis.

(translated by the author from $\S 1$ BWaldG $1^{\text {st }}$ version published on May $2^{\text {nd }}, 1975$ by: BGBl. 1975 I S. 1037)

Box 1. The adoption of the idea of SFM in the $1^{\text {st }}$ version of the German Forest Act of 1975

In 1975, the new environmental awareness lead to the passage of first German forest act (BWaldG). It adopted Carlowitz' ideas of sustainable forest management and extended the traditional idea of sustained timber production by new aspects of environmental conservation. As a consequence, formally, sustainable forest management (SFM) was not only devoted towards harvestable volumes anymore, but it also embraced ecological and social forest 
functions such as the regulation of the climate, water balance, prevention of air pollution, maintenance of soil fertility and recreation (cf. Box 1).

In order to measure the success of such practices and associated policies, forest reports became an important tool. Thus, by section 40, paragraph 3 the federal forest act of 1975 (BWaldG) recognized the importance of forest data for that purpose and provided a mandate to assess the success of state subsidies to the forestry sector. It firstly demanded a national report to the parliament (Bundestag) with information on the state and development of the forest sector and the condition of protective and recreational functions of forests. That section did not yet include a mandate for a national-level inventory. But instead, the forest report focussed on economic statistics which were to be compiled from individual data provided by the forest management units (cf. Box 2).

\section{§ 40 Subsidies}

"(3) In the report as per $\S 4$ of the agriculture act published on September $5^{\text {th }}, 1955$ (BGB1 I S. 565), and based on economic developments of the states' forest administration and on statistics of the forest management unit, the federal government reports to the German Bundestag on the situation and development and on the structure of the forest sector within the federal territory, as well as on the measures required for the support of the forest sector [note by the author: here, "support of the forest sector" refers to subsidies]. This report also extends to the [economic] burdens from protective- and recreational functions."

(translated by the author from $\S 1$ BWaldG $1^{\text {st }}$ version published on May $2^{\text {nd }}, 1975$ by: BGBl. 1975 I S. 1037)

Box 2. First mandate for forest reports and predecessor of forest inventory mandates by the German Forest Act as published in 1975 (BGB1. I S. 1037)

A mandate for a nationally harmonized inventory was enacted 9 years later in 1984 by the first amendment of the national forest act (BGB1. I S. 1034). The new law wanted "to provide a general overview of large-range forest condition and productivity" ( $\$ 41 \mathrm{a})$. That section shows that at this time, the purpose of the National Forest Inventory (NFI) was still more targeted towards economic considerations in terms of harvestable timber and to national policy-making. The first national inventory of the Federal Republic of Germany followed 
these requirements. On a $4 \times 4 \mathrm{~km}$ grid, the first sample-based forest inventory in the old western states of Germany measured mainly variables of economic concern, such as forest area and growing stock (BMEL, 1986). The observations show that neither the inventory, nor its mandate did yet embrace the new legal understanding of SFM aiming as well at the provision of ecological and social forest functions and services. These enhancements followed 35 years later, when in 2010 the amendment of the national forest act (BGB1. I, 2010 S. 1050) extended the mandate and paved the way for a new inventory protocol. Since 2012, the third NFI included new variables for improved assessments of areas with protective, recreational and ecosystem functions (BMELV, 2014). A more detailed elaboration on these political and technical developments follows later in Chapters 2 and 3 of this thesis.

\subsubsection{UNECE Clean air policy and monitoring forest health}

Parallel to the German development of a national forest policy and the implementation of a legal mandate for a NFI in the late 70s and early 80 s, the public outcry about acid rain and the predicted consequences of eutrophication on forest health, together with the new environmental awareness and a concern of air-pollution effects on human health triggered changes in international policy-making. It gave rise to international reporting obligations on forest health and biodiversity. In 1979, in Geneva, 51 UNECE member states signed a cleanair policy, the "Convention on Long-Range-Transboundary Air Pollution" (CLRTAP) which entered into force in 1983. Though it had been initiated as a platform for negotiations on voluntary emission targets, it gradually evolved into a Convention with legally binding emission reduction targets (UNECE, 2017). Focussing, initially, on emissions of sulphur oxides (Helsinki Protocol on the Reduction of Sulphur Emissions or their Transboundary Fluxes by at least 30 per cent) and then on compounds of nitrate (1988 Sofia Protocol concerning the Control of Emissions of Nitrogen Oxides or their Transboundary Fluxes), the convention initially focussed on issues of acidification. Later, the parties of CLTRAP negotiations recognised that policies on forest health must also take account of photochemical oxidant products. They thus included emission targets towards the reduction of Volatile Organic Compounds (VOCs) (1991 Geneva Protocol concerning the Control of Emissions of Volatile Organic Compounds). Heavy metals and Persistent Organic Pollutant (POP), as well as fine particulate matter (1999 Gothenburg Protocol to Abate Acidification, Eutrophication and Ground-level Ozone) were added more recently to provide a more holistic picture of pollutants affecting forest health and vitality. 
It is to note that it was forest health and an implicit concern of pollution effects on human health, that were the primary initiators and drivers for 1980s negotiations on the CLTRAP's emission targets. Though the convention covered also active and highly active greenhouse gasses $\left(\mathrm{CO}_{2}, \mathrm{Ch}_{4}, \mathrm{~N}_{2} \mathrm{O}, \mathrm{NO}_{\mathrm{x}}, \mathrm{CO}, \mathrm{NMVOCs}\right.$ and $\left.\mathrm{SO}_{2}\right)$ issues of climate change were addressed and reinforced some years later by more climate-specific mitigation policies, the 1994 UNFCCC, the 1997 Kyoto Protocol and the 2015 Paris Agreement (Ch. 1.1.3).

As for CLTRAP and its clean air policies, the political recognition and the mandatory nature of regulations significantly contributed to the impact of monitoring regulations on inventory programmes. Policy-makers recognized that the success or failure of implementation of policy targets must best be monitored and evaluated along scientific standards. Hence, within the framework of CLTRAP in 1983 (Michel et al., 2014), the UNECE member states established the International Co-operative Programme on Assessment and Monitoring of Air Pollution Effects on Forests (ICP Forests) as a platform for inventory research. It has established the first Pan-European inventory and monitoring programme in 1986 (Sanders et al., 2016). On a $16 \times 16 \mathrm{~km}$ grid of permanent sample-plots (Level I), and a subsample of more intensive monitoring (Level II), the inventory now provides measurements on forest growth and biodiversity, including species of woody plants, ground vegetation, mosses and lichen (UNECE ICP Forests Programme Co-ordinating Centre, 2016). In combination with emission records and variables on defoliation, foliage discoloration and litterfall, the assessments provide information on forest ecosystem health and vitality, as well as on underlying threats. These additional variables comprising biotic and abiotic agents, such as pests and diseases or chemical and physical disturbances, and the assessment of their effects on forest health are probably most important as they identify dangerous human activities that may be addressed actively by policy making.

Also continuity of measurements was, and still is an advantage. In Germany and the other member states, the monitoring programme runs under permanent ministerial funding and temporary but regularly renewed co-financing of the European Commission (first: "Forest Focus", i.e. Regulation (EC) No 2152/2003, then: "LIFE+", i.e. Financial Instrument for the Environment). It was therefore possible to establish a permanent monitoring scheme with forest condition reports presenting results annually (reports available online: http://icpforests.net/page/icp-forests-technical-report).

These advantages had been acknowledged on the political level, following a 1990 meeting of "Pan-European" ministers (including Russia and European nations) in Strasbourg, the 
inventory had gained international recognition. In spite of the relatively low resolution of sample grid when compared to the NFIs of European states, the greatest advantage of the PanEuropean inventory was its ability to provide harmonized, i.e. comparable data on a crossnational level and on a continuous basis. Also their capacities to statistically model environmental cause-effect relationships and to identify the strongest drivers of environmental change have been recognized by European policy-makers (MCPFE, 1990).

Subsequent European harmonisation initiatives such as those funded under the "European Cooperation in Science and Technology" (COST Action E43 2004-2008, cf. www.metla.fi/eu/cost/e43/)) which aimed at harmonising existing and future NFIs did not achieve a comparable political recognition. At least, they were not endorsed as default data providers to Pan-European or UNECE Forest Resource Assessments.

The situation was different for data from the Pan-European forest health inventory which has been chosen a default dataset for the FAO forest resource assessment (indicators "Deposition of air pollutants", "Soil condition" and "Defoliation") (UNECE ICP Forests Programme Coordinating Centre, 2016). The foundation for the inventory was laid in 1990, in Strasbourg. Here, the Pan-European member states which are also represented by the Ministerial Conference on the Protection of Forests in Europe (MCPFE) adopted Resolution S1 (MCPFE, 1990). It commits countries to introduce the ICP Forests-inventory design as a standard data source for international reporting obligations beyond its original purpose of clean-air monitoring. Such obligation include the European and the Global forest resources reports ("State of Europe's Forests", "Global Forest Resource Assessment" - FRA) from the United Nations Food and Agricultural Organization (FAO/UNECE). The political relevance of the Pan-European forest health inventory programme increased further after MCPFE resolutions have recognized not only environmental problems of forest pollution, but also the threats evolving from climate change and loss of biodiversity.

\subsubsection{Climate change and monitoring carbon emissions}

Among others, the political recognition of climate change by MCPFE helped to prepare subsequent political commitments (Thomas, 1996) at the United Nations Conference on Environment and Development (UNCED) in Rio de Janeiro in 1992, also referred to as "Rio 92" or the "Earth Summit". At that summit, the United Nations Framework Convention on 
Climate Change (UNFCCC ${ }^{11}$ ) opened for signature, and became effective in 1994. It committed countries to protect the climate and to stabilise greenhouse gas emissions at 1990 levels by 2000. In 1998 the Kyoto Protocol ${ }^{12}$ established tougher goals when, industrialised states including Germany, Poland and Sweden, all of which have a strong forestry sector, committed to reduce, by 2020 , their greenhouse gas emissions by specific and individually defined target-values compared to 1990 baseline levels. The Paris Agreement of $2015^{13}$ is the successor of the Kyoto Protocol after its expiry in 2020 and formulates the 2030 target to keep the increase of the global average temperature to well below $2^{\circ} \mathrm{C}$ above pre-industrial levels (Article 2). In addressing that target, for the first time, the developing world is not anymore acting in isolation. Instead, also developing countries have committed to contribute to climate targets via so-called "nationally determined contributions" (NDCs in Articles 3 and 4, Paris Agreement). The world has thus made a significant step towards addressing climate change in a more cooperative approach.

In the earlier course of the described policy-making process towards the adoption of Kyoto Protocol, targets did not initially account for forests to contribute to climate goals and to serve as carbon sinks, but following negotiations and improvements, political emission reduction targets have been constantly reviewed and extended to address the causal link between forest management activities and their effects on aspired climate goals. The need to monitor achievements of the management strategies towards the defined emission reduction targets, led the European Commission to establish a tool for monitoring reporting and verification (MRV) of greenhouse gas emissions (GHG) with a legally-binding character, the 1993 "greenhouse gas monitoring mechanism regulation" (GHG MMR) (Council Decision 93/389/EEC). The purpose of the new mechanism was to make member states' monitoring and reporting programmes comply with clearly defined statistical standards defined by the Intergovernmental Panel on Climate Change (IPCC) (available online at: https://www.ipccnggip.iges.or.jp/public/index.html), such as to guarantee "timeliness, completeness, accuracy, consistency, comparability and transparency of reporting by the Community [the EU] and its Member States to the UNFCCC Secretariat" (Article 1d in: 2003/0029/COD). In 2013, following a legislative proposal of the Commission and agreement by the Council and the European Parliament, the MMR (Regulation (EU) No 525/2013) significantly enhanced technical data quality requirements, including for instance estimates on emissions and

\footnotetext{
${ }^{11}$ UNFCCC legal citation: 1771 UNTS 107; S. Treaty Doc No. 102-38; U.N. Doc. A/AC.237/18 (Part II)/Add.1; 31 ILM 849 (1992)

${ }^{12}$ Kyoto Protocol legal citation: UN Doc FCCC/CP/1997/7/Add.1, Dec. 10, 1997; 37 ILM 22 (1998)

${ }^{13}$ Adoption of the Paris Agreement legal citation: FCCC/CP/2015/10/Add.1
} 
removals from land use, land-use change and forestry (LULUCF in Art.7(1)d of the MMR). The MMR will expire after the end of the 2020 commitment period of the Kyoto Protocol, meaning that under the Paris Agreement and its 2030 target, maintenance of internationally standardised LULUCF accounting rules requires political action on a recast of a comparable mechanism for monitoring and reporting greenhouse gas emissions beyond the 2020 horizon. Policy makers have accepted the need for action, meaning that the relevant legislative process on amended monitoring and reporting regulations has started in 2016 (cf. European Commission Procedure 2016/0230/COD) and was still ongoing by the time of writing this thesis (December, 2017).

The installation of these international MRV regulations reflects the increased political expectations towards scientific monitoring programmes at the European level and also laid the foundation for national improvements of German NFIs. In 2008, following the start of the first commitment period of the Kyoto Protocol of UNFCCC and the requirement to include emissions from human-induced afforestation, reforestation and deforestation in carbon balancing (Kyoto Protocol Article 3, paragraph 3), also the German government officially recognised forests as carbon sinks. This acceptance has led to the alignment of Germany's NFI-reporting cycle to the first commitment period of the Kyoto Protocol and UNFCCC. Thus for the first time, consistent and nationally harmonised re-measurements allowed the observation of trends of afforestation and reforestation towards meeting emission targets. In subsequent years, the political recognition even led to further extensions when in 2010, the amendment of the national forest act formally endorsed the NFI as a cornerstone for monitoring carbon sinks. In response, the 2013 inventory (NFI III) included additional variables on land-use and land-use change. It further improved volume functions and streamlined measurements of live trees and dead-wood to UNFCCC requirements.

\subsubsection{EC Habitats Directive and monitoring forest habitats}

In the aftermath of the public wake-up call for a new environmental awareness and the publication of the first "Red List" of endangered species in the 60s and 70s, the adoption of two landmark biodiversity policies paved the way to further extension of national inventory mandates and programmes. The Berne convention (Treaty No. 104) and the Birds-Directive (Council Directive 79/409/EEC) of 1979 were both introduced as the predecessors of the common European biodiversity policy, generally referred to as "Natura 2000". 
Natura 2000 is a European network of protected forest- and non-forest habitat types, so-called "habitats of community interest" with legally binding management regulations. For better readability, in this thesis, I will refer to those habitats as "European-", or "EU habitats". They are further defined and listed by Annex I of the "Council Directive 92/43/EEC of 21 May 1992 on the conservation of natural habitats and of wild fauna and flora". The document is commonly referred to as the "Habitats Directive" and was signed at the United Nations Conference on Environment and Development (UNCED) in Rio de Janeiro in 1992, also referred to as "Rio 92" or the "Earth Summit". The directive aims to "promote the maintenance of biodiversity, taking account of economic, social, cultural and regional requirements" and thus "makes a contribution to the general objective of sustainable development" (Section B, Habitats Directive, 1992). The directive further defines "conservation status" of European forest habitats as a general indicator of environmental health and policy performance. The target is achieved when national monitoring and reporting programmes classify the categorical index as "favourable". For the purpose of measuring that achievement, Article 17 (Habitats Directive) obliges member states to monitor progress on a landscape-scale approach. It includes forest and non-forest habitat types in the nine predefined "biogeographical regions": Alpine, Atlantic, Black Sea, Boreal, Continental, Macaronesian, Mediterranean, Pannonian and Steppic. The respective habitat types are defined in Annex I of the directive and are to be monitored on a 6-year basis.

This obligation is legally binding and member states have therefore responded to this obligation by a variety of monitoring programmes. To suffice requirements, Germany initially used only sub-national, i.e. state- or Länder-specific monitoring programmes. These were combined with a federal programme administered by the Federal Agency for Nature Conservation $(\mathrm{BfN})$. Both provided detailed information on the area and condition of habitat types, but they did neither cover all areas of Germany, nor did they allow nation-wide estimates (cf. results in Chapter 4). Thus, in 2006 the DeCOVER project was initiated as a research project funded by the Federal Ministry of Economics and Technology (BMWi) via the German Aerospace Center (DLR) (Buck, 2012, and Keil et al., 2010). On 4 selected test sites, it explored the applicability of remote sensing data for monitoring of protected habitat types under the NATURA 2000 framework. It combined optimal satellite image layer from the European CORINE Land-Cover (CLC) project (made up of SPOT 4, SPOT 5 and IRS-P6 satellites images) with the up-to-date remote sensing satellite systems RapidEye and TerraSAR-X. However, the outcomes were obviously not convincing enough to suffice political requirements. At least, until today, the project has not become operational for 
administrative reporting purposes. Instead, after the end of the project in 2012, sample-based inventory data moved again into political focus. The newly amended German Forest Act of 2010 extended the mandate of the NFI to assess EU habitat types from 2012, and to support reporting obligations under Habitats Directive (BMELV, 2014). More details on this topic will follow in Chapter 3 which explores the national political backgrounds of NFI amendments.

\subsubsection{The Convention on Biological Diversity and its reporting programmes}

\subsubsection{General Considerations}

Data reported under Habitats Directive does not only inform policy-makers at the European level, but it is entwined with policy negotiations on the international level as well. In fact, the Habitats Directive is only one component of international biodiversity policy. As such it represents the European contribution towards the implementation of an overarching, global biodiversity policy, the United Nations Convention on Biological Diversity (CBD) of 1992.

Both agreements, the regional Habitats Directive and the global CBD were opened for signature at the Earth Summit in Rio de Janeiro 1992. Following the calls of Environmental Non-Governmental Organisations (ENGOs) to combat the loss of biodiversity by an international biodiversity agreement (Raustialia, 1997), the CBD entered into force in 1993 and has now been signed by 168 states. Based on intensive negotiations between ENGOs who sought to publicize information on biodiversity loss and states who feared economic losses (Raustialia, 1997), the CBD formulated three linked objectives: "the conservation of biodiversity", "the promotion of its sustainable use" and "the equitable sharing of benefits" (Article 1, CBD, 1992). It further required member states and the European Union to translate these objectives into European- and national biodiversity strategies (Article 6a, CBD, 1992)

In line with the implementation of such strategies, the global targets were specified and amended several times. Most recent changes come from the tenth meeting of the CBD Conference of Parties (CBD/COP), held from 18 to 29 October 2010 in Nagoya, Aichi Prefecture, Japan. Here policy-makers updated the global Strategic Plan for Biodiversity 2011-2020 (UNEP/CBD/COP decision X/2, 2010) and adopted the so-called 20 "Aichi targets" (cf. Annex I). 
The expectations are high because UN policies affect multiple decision-making scales and CBD negotiations needed to account for and integrate interests of many different stakeholders at both, national and international jurisdictions. Thus, beyond the requirement of meeting expectations of global policy-makers such as ENGOs and existing global policies on sustainable development and climate change, the global Aichi-targets also needed to integrate national biodiversity policies and the new European targets of the 2011 EU Biodiversity Strategy to 2020 (COM(2011) 244 final).

The policy also had implications for national and international monitoring programmes because the successful implementation of agreed targets needed a mandate that enforced the measurement of compliance. Thus, CBD member states designed a new obligation that committed its members to monitor "through sampling and other techniques" (Article 7, CBD, 1992) the progress towards the respective biodiversity objectives. These policy-making- and reporting obligations applied to all members of the CBD. Reporting was therefore relevant to the individual member states, but also to the European Union, which forms as a separate member entity.

For the purpose of fulfilling that obligation and for the development of a harmonised reporting framework, the EU and the UNCBD have each mandated two distinct initiatives to develop principally two sets of indicators: The global "Ad Hoc Technical Expert Group" (AHTEG) on Indicators for the Strategic Plan for Biodiversity 2011-2020, which was mandated by the CBD's member states (cf. UNEP/CBD/COP decision X/7, 2010), and the regional initiative "Streamlining European Biodiversity Indicators" (SEBI) which works on behalf of the European Union.

It is to note that the respective reporting tools are not directly comparable to the MRVinstrument of carbon reporting (Ch. 1.1.3). The reason is that neither CBD, nor its following indicator initiative included statistical standards and precision requirements comparable to those developed under the IPCC framework. Instead of designing new statistical methods, the biodiversity indicator initiatives focussed on utilising existing methodologies and indicator programmes. More details on the origin of the European and global indicator initiatives and the development of the two distinct European and Global datasets follow below in the next two sub-sections. 


\subsubsection{The European Biodiversity Indicator Initiative under CBD}

The idea of a European indicator programme developed in response to the CBD's obligation to monitor policy achievement. A complex national and international policy background defined the political targets to be monitored and thus expanded expectations towards the indicator programme. Eventually, the political targets to be evaluated did not only include those of CBD but also national and regional ones. The background is that CBD required the translation of the CBD targets into national and regional biodiversity strategies and action plans. The EU responded to this obligation by its 1998 Biodiversity Strategy (COM 1998/42). The strategy was later complemented by amendments in 2011 (COM 2011/244) and by 4 sector specific Biodiversity Action Plans in 2001(COM 2001/162), covering issues of conservation of natural resources, agriculture, fisheries, and economic and development cooperation.

In subsequent decisions, targets of the Biodiversity Action Plans influenced other policy development processes. In effect, biodiversity reporting became relevant to policy issues beyond aspects of biodiversity. At the 2001 Gothenburg summit for instance, the EC biodiversity targets added an environmental dimension to the sustainable development negotiations and resulted in the headline objective to "halt the loss of biodiversity by 2010 " as formulated by the EU sustainable development strategy (COM 2001/264). The acceptance of biodiversity as a component of sustainable development and its multitude of environmental, economic and social targets eventually expanded the scope of policy targets to be monitored and, simultaneously, the expectations towards European biodiversity inventories.

This expansion of political expectations started with the sustainable development strategy, which obliged the European Commission to "establish a system of biodiversity indicators by 2003". Later and in response, the "Kiev Resolution on Biodiversity" (ECE/CEP/108) at the fifth Ministerial Conference Environment for Europe (Kiev, Ukraine, 2003) reinforced the objective to implement "by 2008, an operational and coherent European programme on biodiversity monitoring and reporting". This monitoring commitment initiated the formulation of political data requirements and the development of policy-effectiveness indicators for reporting purposes.

In 2004, by the multi-stakeholder agreement "Message from Malahide", delegates from 22 EU-Member States, 1 non-Member State (Norway), conservation agencies and nongovernmental organizations, and representatives of key economic sectors including agriculture, forestry, fisheries and industry agreed upon the first set of headline biodiversity 
indicators to monitor progress to 2010 EU biodiversity commitments as formulated by the CBD 1992. These policies with all their different expectations formed the mandate of the European indicator programme.

However, the problem with potentially available data sources was that several member states had already developed very different indicators and monitoring programmes. These were originally designed for other national- and sector-specific targets of various political agreements (e.g. national biodiversity strategies, forest reports to national governments, UNClimate Conventions). Data sources were therefore neither comparable, nor compatible at the European level. To overcome these problems and to harmonize assessment methods, in 2005, the European Commission initiated the project "Streamlining European Biodiversity Indicators" (SEBI). The objective was to develop a European set of biodiversity indicators that may utilise the existing datasets (EEA, 2007) and serve data requirements of both, the EU Biodiversity Strategy and the CBD. Under the umbrella of the European Environment Agency (EEA), the following discussions included 120 experts (ten Brink, 2010) with representatives from existing monitoring programmes, from national governments, ENGOs, the European Commission and the EEA. The definition of indicators, attributes and thresholds therefore depended upon both, (1) agreement among the participating stakeholders and (2) availability of data sources. The motivation was to harmonise assessment methods, to avoid duplications and to limit inventory- and monitoring burden.

By 2014 the SEBI database eventually comprised 26 indicators (Annex II), which are managed by EEA and are publically available on the Biodiversity Information System for Europe (BISE). Out of those indicators, 10 referred to forest areas and were potentially relevant for forest inventories. Among others, they comprise biodiversity data from national (NFI, national inventories of EU-Habitats) and international inventories and mapping programmes (EEA, EC database on Article 17 reports).

\subsubsection{The Global Biodiversity Indicator Initiative under CBD}

The following section describes how the previously described set of European indicators influenced the following indicator initiative under the CBD's Conference of Parties (COP). The global recognition started with the first set of European biodiversity indicators and the "Message from Malahide" 2004. Even though these indicators were mainly developed on the background of European policy issues, the CBD endorsed them for global targets in the same year (UNEP/CBD/COP decision VII/30, 2004). This recognition initiated the foundation of a 
global set of indicators. Same as the European Commission's SEBI initiative, the CBD Conference of Parties (COP) wanted to support harmonised reporting to global biodiversity targets by a common mechanism. Eventually, under supervision of the "United Nations Environment Programme" with the ENGO "World Conservation Monitoring Centre" (UNEPWCMC) the "Biodiversity Indicators Partnership" (BIP) came into being and held its first meeting in 2005 .

On the global level, the effectiveness of biodiversity policy is now measured using an amended BIP. This new initiative had been re-established following the failure to meet the global 2010 targets and the need to measure policy achievement to a new 2020 Horizon. Thus, since UNEP/CBD/COP decision X/7 at its 10th meeting (COP 10) in 2010, the biodiversity indicator partnership (BIP) has been renamed the "Ad Hoc Technical Expert Group" (AHTEG) on Indicators for the Strategic Plan for Biodiversity 2011-2020.

The new initiative further amended the indicators' attributes and baselines. These definitions were influenced by the CBD but also by data sources provided via related policies. In 2008 for instance, at its $9^{\text {th }}$ meeting in Bonn, the CBD COP endorsed targets on sustainable forest management as defined by the "United Nations Forum on Forests" (UNFF) and invited UNCBD members to cooperate with the UNFF secretariat and other members of the "Collaborative Partnership on Forest" (CPF) for the purposes of data exchange (UNEP/CBD/COP decision IX/5, 2008). That decision eventually increased the political recognition of forests and the sustainable management of its resources for the overall objective of halting the loss of biodiversity.

With the invitation to share knowledge on SFM, data of UNFF and other members of the CPF became relevant to biodiversity reporting as well. This included evidence from national(NFIs) and Pan-European forest inventories (ICP Forests) as reported to Forest Europe/UNECE/FAO datasets. In Chapter 4, I will show that the same inventories were also used in the European SEBI initiative, indicating an increased political recognition of forest inventory data in two political domains: biodiversity and sustainable forest management.

\subsubsection{A non-legally binding forest policy and the Pan-European Criteria and Indicator Initiative}

Until today the abovementioned interpretations of sustainable forest management in terms of sustained 1) Productivity, 2) Maintenance of biological diversity, 3) Mitigation of climate change and 4) Pollution, remained enshrined into separate political agreements and policies 
under CBD, FCCC and CLTRAP. Humphreys (2006) describes such a forest regime as multicentric and "fragmented". To further emphasise that multi-centric and fragmented nature a regime that is characterised by a complex of very different and sometimes opposing objectives, Rayner et al. (2010) have later proposed the notion of a "forest regime complex". This term is opposed to a uni-centric forest regime where policy making is streamlined to pursue a singular legally binding political goal.

Though UN-secretariats of CBD, FCCC and CLTRAP aim for cooperation and started initiatives to streamline definitions and foster data exchange under the Collaborative Partnership on Forests (CPF), there is yet no consent on a comprehensive, legally binding definition of sustainable forest management that may provide the basis for obligatory monitoring and reporting mandates. As a result, a harmonised indicator framework with legally binding monitoring and reporting responsibilities has not been designed yet. Data rather comes from fragmented sources of individual monitoring and reporting processes. In the following, I will explain the political developments and indicator processes that influenced current reporting programmes on sustainable forest management (SFM)

(A) Sustaining the multiple roles and functions of all types of forests, forest lands and woodlands;

(B) Enhancing the protection, sustainable management and conservation of all forests, and the greening of degraded areas, through forest rehabilitation, afforestation, reforestation and other means of rehabilitation;

(C) Promoting efficient utilization and assessment to recover the full valuation of the goods and services provided by forests, forestlands and woodlands;

(D) Establishing and/or strengthening capacities for the planning, assessment and systematic observation of forests and related programmes, projects and activities, including commercial trade and processes;

Box 3. Objectives of Chapter 11 "Combating Deforestation" of Agenda 21 (in: United Nations, 1992b)

First ambitions of harmonizing definitions of SFM globally started in Rio 1992 with the adoption of Chapter 11 of Agenda 21 (United Nations 1992b) and the "Non-legally binding authoritative statement of principles for a global consensus on the management, conservation and sustainable development of all types of forests" (United Nations, 1992a). The agreement 
was important for fostering a new international concept of sustainable forest management because it firstly acknowledged the multiple ecological, economic and social functions of forests and combined objectives to protect forest-based resources and services together with their sustainable utilisation (Box 3).

Also European policy makers recognized the need for thematically inclusive objectives. Thus, in 1993, in Helsinki, member states of the Pan-European Ministerial Conference on the Protection of Forests in Europe (MCPFE), now renamed as "Forest Europe", proposed a first set of general management guidelines, thus providing a first agreement on a definition of sustainable forest management. This definition, however, was not precise enough to allow a translation into measureable variables. Thus, in 1994, an expert committee proposed a core set of 6 criteria and 27 quantitative indicators for sustainable forest management in Europe (MCPFE, 2001). Subsequently, data collection was arranged to be covered by the UNECE/FAO Temperate and Boreal Forest Resources Assessment 2000 (TBFRA 2000). Until today FAO collects data on behalf of Forest Europe (previously MCPFE) and at the Third Ministerial Conference in Lisbon in 1998 the MCPFE reported on the status of SFM in Europe using the pan-European criteria and indicators. At that conference, reported results were agreed to be useful for monitoring SFM and the ministers responsible for forests endorsed the 6 criteria and associated indicators by signing Lisbon Resolution L2 (MCPFE, 2001). In the course of harmonizing the European definitions with those of other continents and with the UNECE Conventions (e.g. UN-CBD, UN-FCCC, UN-ECE-CLRTAP) the set of Pan-European Indicators was constantly reviewed and modified in the next years. The final catalogue comprised 7 criteria and 34 associated indicators for SFM, which were officially endorsed by the 7th Ministerial Conference in Madrid 2015 (Annex III).

Parallel to the described development of a new monitoring and reporting framework, major political changes increased the political relevance of the MCPFE indicator framework in 2007. The "Non-Legally Binding Instrument on All Types of Forests" (in 2015 renamed the "United Nations Forest Instrument" by E/CN.18/2015/L.2/Rev.1, paragraph III (8)) was adopted by the Member States of the United Nations (UN) (ECOSOC resolution 2007/40) and defined the concept of SFM by the "4 Global Objectives on Forests" in its Section IV and the "seven thematic elements on sustainable forest management" in Section V (ECOSOC resolution 2007/40) (cf. Annex IV). The seven thematic elements were structured around the pan-European indicators of MCPFE (Annex III). In the framework of revision of the UN 2020 targets and establishment of the 2030 Agenda, in 2017, the first ever "UN Strategic Plan for 
Forests" extended these seven thematic elements to 19 "indicative thematic areas for action" specifying sustainable forest management under the 6 "Global Forest Goals" (UN, 2016). The 6 "Global Forest Goals" and their "Indicative thematic areas for action" were principally meant as an extension to the "4 Global Objectives of Forests" to address more comprehensively the issue of sustainable forests management by including additional targets of the Rio Conventions (UN-CBD, UNFCCC, UNCCD). National inventory data used within assessments of these processes has therefore become fundamental for global discussions on legally binding management standards on forests. But, as long as there is still no agreement on such a new convention, member states are not obliged to create particular mandates and inventory programmes to serve the proposed definitions of SFM. Instead they may choose data from the pool of existing monitoring programmes provided under existing conventions. The MCPFE indicator initiative and the UN Strategic Plan for Forests therefore has no direct legal effect on inventory programmes, but vice versa NFIs may continue to indirectly influence discourses on sustainable forest management standards by informing public discourse and policy makers (cf. Figure 1). Chapter 3 will show how such information has influenced political perceptions, and which kinds of data sources have moved issues of biodiversity conservation into political focus recently.

\begin{tabular}{|c|c|c|c|}
\hline \multicolumn{4}{|c|}{$\begin{array}{c}\text { Sustainable forest management } \\
\text { (with political agreements and 4 core-topics) }\end{array}$} \\
\hline $\begin{array}{c}\text { Lorest areas only } \\
\text { UNFF } \\
\text { (voluntary) }\end{array}$ & $\begin{array}{c}\text { Landscape-scale (in- and outside forest areas) } \\
\text { UNFCCC/ Kyoto } \\
\text { Protocol } \\
\text { (obligatory) }\end{array}$ & $\begin{array}{c}\text { PNECE/CLRTAP } \\
\text { (obligatory) }\end{array}$ & $\begin{array}{c}\text { Biodiversity } \\
\text { UNCBD } \\
\text { (obligatory) } \\
\text { EC-Natura 2000 } \\
\text { (obligatory) }\end{array}$ \\
\hline & \multicolumn{4}{|c|}{ Inventory data and other sources } \\
\hline
\end{tabular}

Figure 1. Policies on SFM and data exchange between their monitoring instruments (arrows show data exchange, grey shade highlights biodiversity concerns as an emerging topic of policy interest) 


\subsection{The risks of scientific policy advice}

The previous sections showed that, formally, the provision of information is highly relevant for informing political agreements. In an ideal scenario, where the objective is to come to "well-informed" decisions such information shall not only be politically relevant but also scientifically sound. However, as soon as inventory specialists and other scientists seek to provide politically relevant data and engage into political questions, they are faced with another problem: Issues of credibility. As shown in the following sections, such issues evolve from the involvement into the political domain and the use or instrumentalisation of scientific information by politicians.

The basic problem is that two diametrically opposed principles meet at the interface of political data use and scientific data generation: (1) "political interest" and (2) "scientific neutrality". Neutrality is the basis of credibility and requires scientific independence and absence of ideologies or political values. Political interests on the other hand are inherently value-laden. Thus, politicians are elected, i.e. legitimated, for their representation of subjective values and the inherent democratic understanding that these values lead to decisions that are in best interest of the majority (Krott, 2012).

As soon as scientist now enter a value-laden political discourse by providing information that supports a specific decision or policy, they become, perhaps unknowingly, supporters or advocates of a political agenda (Guldin, 2003; Mills and Clark, 2001). O'Brien (1993) and Shannon et al. (1996) believe that scientists cannot avoid such advocacy. Others even make it an ethical responsibility, where scientists shall inform decision-makers to support better decisions in the interest of society as a whole (McCoy, 1992; Barry and Oelschlaeger, 1996). Due to such involvement of scientists into political questions and societal values, some authors criticize "the illusion of 'neutral' and 'objective' analysis" (Hertin et al., 2009), i.e. bias of data generation due to selective focus of research on hot topics of political or societal interest (Hellström, 2000 quoted by Janse, 2008).

Some authors take a stronger stand against the so-called "politicization of science" (Krott, 2012; Krott et al., 2014; Pregernig, 2007). They generally do not support the idea that advocacy is a societal responsibility of science, but they believe that advocacy benefits only specific groups of stakeholders. In that theory, powerful political actors are believed to actively and intentionally influence research output or to select information for specific political interests (Krott, 2012; Haas, 2004). In that theory political power is a major driver (Krott, 2012; Krott et al., 2014). Because power and interests are assumed to be properties of 
specific groups, political influence and data selection may lead to sub-optimal decisions, i.e. decisions that are not in the interest of the majority but only for a selective group of powerful stakeholders. In such cases, lobbies and decision-makers instrumentalise data to support a specific pre-defined argument or decision (Risse, 2004; Hertin et al., 2009; Krott, 2012; Pregernig, 2007). This is in contrast to well-informed or science-based decision making, where evidence would come first (Dietz, 2003; Failing and Gregory, 2003; Keeney and Gregory, 2005; Arnold et al., 2014b).

Due to such potential political influence on data selection and interpretation, some authors refer to rationalist ideas of decision making as "naive" (Hertin, 2009; Haas, 2004). They postulate that the assumption of a best-practice approach in decision-making, i.e. a linear transfer of data that leads to optimal decision outcomes in the best interest of environment and society is unrealistic and "never works" in practice (Krott, 2012, p. 39). The argument is that political interests are much stronger than scientific standards (Krott, 2012). Such theories assume that actors accept sub-optimal decisions in order to enforce own interests and to establish political power (Krott, 2012, 2013). Some authors, even speak of a "politically wanted", "ineffective" or "failed" forest regime (Humphreys, 2006, 2009; Chaytor, 2001; Dimitrov, 2005; Dimitrov et al., 2007) which is, some argue, supported by the selective use, manipulation or intentional ignorance of scientific evidence (Hertin et al., 2009; Krott, 2012; Pregernig, 2007).

This thesis refers to such data procurement, where information is used selectively and instrumentalised or biased to support political interests of selective groups of stakeholders, as "fragmented". In this thesis, that terminology will be essential for the analysis of the forest regime. That regime has previously been described as a "fragmented forest regime complex" (cf. Chapter 1.1.6) because the absence of singular legally-binding forest convention means that policy making is focused on different and sometimes opposing policy objectives of stakeholder groups that seek to enforce individual political interests under the sectoral conventions launched in Rio 1992 (e.g. UNFCCC, UNCBD, UNCCD) and the older Convention on Long-range Transboundary Air Pollution of 1981 (CLTRAP). The extent to which this assumption applies to specific examples of data acquisition processes under policymaking and reporting processes will be questioned by this thesis.

For inventory specialists, the risk with abovementioned political instrumentalisation of science is that politicians avoid liability and responsibility for sub-optimal decision-outcomes. According to Krott (2012), politicians rather refer to their trust in scientific evidence, thus 
making scientists responsible. They say that they cannot challenge scientific evidence and that made decisions were unavoidable (Krott, 2012). Yet, they do disguise the fact that they selected loyal scientists and results (Krott, 2012) which were then interpreted and presented in a way to produce politically favoured conclusions and decisions (Hertin et al. 2009; Krott, 2012; Pregernig, 2007). Such theories suggest that such sort of scientific information is often politically biased, not credible and useless for solving real-world problems. As a consequence, the political use of information can turn to a real threat putting credibility and legitimacy of the scientific community at risk.

This risk of being perceived as biased advocates of some political agenda exists specifically for governmental research agencies, which are usually responsible for national-level forest inventories. The problem lies within the political affiliation and monetary dependency on ministries whose decisions are assumed to be usually more the result of advocacy than of rational problem-solving (Arnold et al., 2014a). In the German context, Winkel et al. (2011) identify two ministries and two interests that together, co-define the framework of forest policy: In that theory, the "Federal Ministry for Food and Agriculture" (BMEL) represents utilitarian interests of the forestry sector, whereas the "Federal Ministry for the Environment, Nature Conservation and Nuclear Safety" (BMU) represents values of biodiversity conservation (Winkel et al. 2011). The common issue area of forestry then implies that ministries, state agencies and their inventory programmes compete for responsibility in order to increase budget, influence and power within the government (Giessen et al., 2014; Niskanen, 1971; Peters, 2010; Krott, 1990). In forestry, an example for such a common issue area is the optimal way of managing forests sustainably. Giessen et al. (2014) and Winkel et al. (2011) have identified the underlying political problems that hindered agreement on management standards. According to their argumentation, the political problem lies within different values and ideologies of competing bureaucratic agencies. They found that utilitarian bureaucracies of BMEL were too much focused on the sustained production of timber, whereas conservation bureaucracies of BMU were more interested in maintaining ecosystem functioning. Many authors believe that such institutional competition of conflicting interests leads to political instrumentalisation of scientists (Winkel et al, 2011; Krott, 2012) and their information (Weible, 2007; Sabatier, 1988). In this context many authors have referred to the "politicization of science" (Weingart, 1982; Pielke, 2004, 2005 2007; Sarewitz et al., 2017) or, more specifically, the "politicization of forestry" (Krott, 2012). In such a political framework, biased conclusions are assumed to impede well-informed decisions and effective policy making, an observation that has also been illustrated by the extensive body of research 
on the failed implementation of forest management standards within an international legally binding instrument on all types of forests (Humphreys, 2006, 2009; Dimitrov, 2005; Dimitrov et al., 2007).

\subsection{Theories on locating political bias in the science-policy-interface}

\subsubsection{General considerations}

The question is where to find political bias that leads to sub-optimal decisions in the policyscience interface. Is it in the domain of scientific responsibilities or in the domain of forest policy-making? To make that distinction it is crucial to distinguish the distribution of respective responsibilities as illustrated in Figure 2. Accordingly, scientists are mainly engaged in data measurement and analysis, while politicians interpret such information for specific purposes of decision-making. In this process, when either scientists or policy-makers violate their codes of good practice in executing their responsibilities, then we can speak of "sub-optimal" decisions. The standards are described in the following two sub-sections (Chapters 1.3.2 and 1.3.3) and may be summarized as 1) scientific credibility of information and 2) democratic decision-making. Both terms basically describe the respective standards that legitimate the existence of scientific- and governmental institutions.

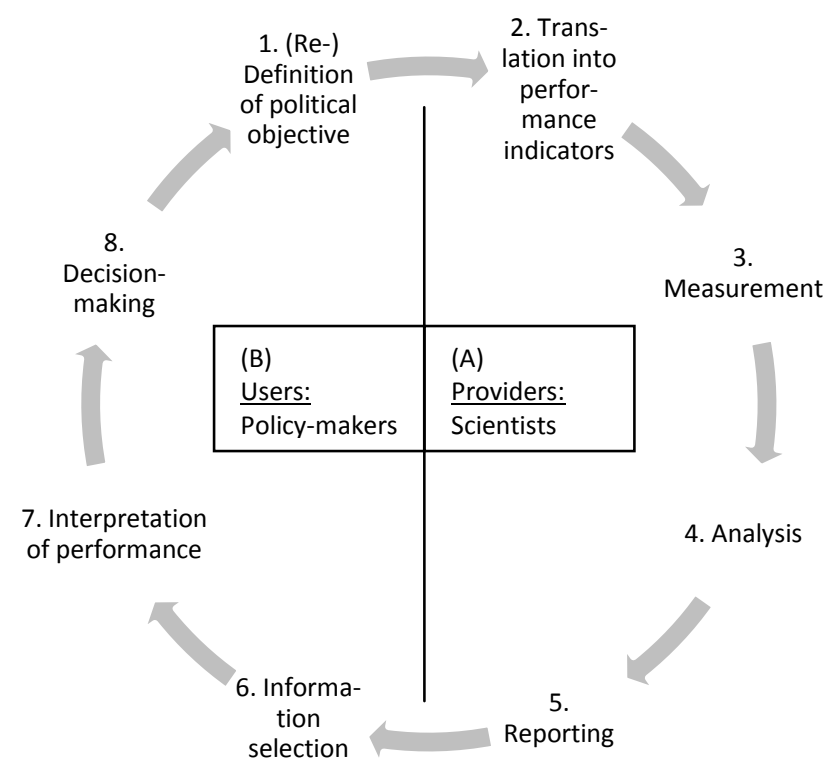

Figure 2. Responsibilities in the science-policy interface. The figure ascribes responsibilities based on primary occupation. Overlap and cooperation between the two stakeholder groups is possible, especially in borderline scenarios described by phases 2 and 5. (modified from: 
Hammond et al., 1999; Janse, 2006; Ascough II et al., 2008; Marcot et al., 2012; Moore, 2012)

\subsubsection{Gaps in democratic decision making - Political bias in the policy domain}

Policy-makers are commonly understood to receive legitimacy by a democratic understanding that objectives and decisions are shared and supported by the majority (Krott, 2012). In such a democratic system all stakeholders participate in the formulation of values and desired outcomes, the so-called "optimal state". In a similar context Pielke (2007) gives the hypothetical example of avoiding casualties of a rapidly approaching hurricane. Saving lives thus defines the democratic decision-making objective. It is then the motivation for choosing all evidence that may help to minimize casualties. On the other hand, in an undemocratic system, informal objectives of powerful stakeholders may lead to politically biased generation of knowledge and sub-optimal decisions. In the above example, such objectives may lead to a hurricane-risk assessment selectively focused on city districts of a politically influential minority. The generated knowledge may then result in the sub-optimal decision of evacuating only selected areas. The effect would be higher casualties in the majority of other districts. In such a hypothetical example policy-makers hide the fact that data selection and decision making was biased towards interests of a specific group. In this study, I refer to those decisions that are based on hidden political interests as "ill-informed" and to the background evidence as "politically biased". Policy makers then violate the rule of democratic decision making for personal benefit which formally undermines their own legitimacy.

Political theory assumes that, in order to formally protect legitimacy, policy makers seek to disguise informal objectives and the fact that information and decision making were driven by political interests and power instead of democratic consent (Krott, 2012). For this purpose, policy makers have two options: Either they falsely interpret scientific evidence in such a way that it supports a politically favoured argument or decision, or alternatively, they select specific kinds of data acquisition methods that allow political interests to bias the assessment result. The latter option relates to methods of measurement and analysis and lies within the scientific domain of responsibilities. Such scientific responsibilities will be analysed separately in Chapters 4 and 5. The other option is to bias decisions, i.e. to make interpretations in favour of specific political interests. Such potential sources of bias within the domain of political responsibilities will be analysed before in Chapter 3 . 
Political science suggests a tool for analysing the risk of such bias in the political domain. As described by Krott et al. (2014), non-transparent or "unverified knowledge" (p.6) is open to political ambitions to influence, manipulate or bias scientific evidence (Krott, 2012, p.37). This might be the case when governments make claims about forest facts without having supporting evidence, then such claims are not verifiable and therefore non-transparent. In the hurricane risk assessment, an example would be a bold political statement claiming that the evacuation was a success without having, nor presenting supporting evidence.

Such sources of bias are not only discussed in political research but they have also been pointed out by decision science which focuses more on optimizing decision-making by mathematical modeling using input data from forest inventory and economics. Thus Keeney and Gregory (2005) raise the concern that "an attribute that is not direct may be preferred by decision makers because of their desire to hide controversial implications of their choices or to present potentially troubling or controversial information in the most favorable light". Here, the problem is seen within the selection of attributes (i.e. variables) that do not directly measure the officially endorsed objective of a policy. An example of such bias arises when governments try to prove the success of hurricane evacuation efforts by making use of the attribute "number of rescue workers" but fail to provide information about the total number of people successfully rescued from the destroyed areas.

In all such hypothetical cases, the political claims and conclusion were made on either incomplete or fully absent evidence. Conclusions are, therefore, non-transparent and difficult or impossible to verify. Following Krott's (2012) theory, we may infer that then, there is the risk of other factors like hidden sources, believes or interests to informally bias the political interpretation. Though such bias originates from politics it can still be harmful for the reputation of scientists, if their evidence is misused as an excuse to justify political action. Guldin (2003) already showed that in such cases, scientists may be perceived as advocates of a political agenda. The blame of badly-informed decisions thus goes to scientists, even though they were not directly involved in the decision-making process.

\subsubsection{Gaps in scientific credibility - Political bias in the scientific domain}

The second option of political influence, i.e. the selection of assessment methods that allows tacit political influence on the research output lies within the domain of scientific responsibilities. Some authors have therefore attributed political bias to the scientific community. They argue that scientific results are often politically biased because they are dependent on politicians who offer funding only to suitable topics (Krott, 1989, quoted by 
Krott, 2012, p. 37) and because politicians selectively consult "loyal" scientists only (Pregernig, 2007, quoted by Krott, 2012, p. 37). According to Krott (2012, p.37) the political intention is hiding unwanted or "dangerous" information. In the example of a hurricane-risk assessment, information on the sample frame (wealthy city districts) may be dangerous, because it could empower critical voices and thus puts at risk the favored decision of saving only rich people's lives. Following that theory, it was beneficial for policy makers to select information that disguised evidence.

In fact, science may contribute to political bias if it violates its own principles. This is most of all transparency of methods, both prior and during assessments (e.g. unambiguous inventory protocols and methods of analysis) and following the presentation of results (e.g. referencing and reporting methods). Non-transparent methods do neither allow validation of results, nor the assessment of statistical bias. Hence non-transparent methods may disguise politically biased methods of data generation. In the hypothetical hurricane example, a non-transparent risk assessment could for instance hide the sample frame, i.e. the wealthy city district. Then data could be politically instrumentalised as illusory evidence pretending that policy action was in the best interest of the community.

\subsection{Objectives and research questions}

\subsubsection{Relevance}

In Chapter 1.1, historical experience showed that several stakeholder groups with an interest into forests (ENGOs, governments, environment agencies) have influenced public perception about forest issues, as much as the formulation of international policies and objectives. As a result, today's policy targets represent a political compromise between the different competing political positions.

To solve these political conflicts on forest management by well-informed decisions, "scientifically sound" evidence that is suitable to measure achievement and to inform discourse is invaluable. The interdisciplinary process of identifying relevant political objectives and translating them into scientifically sound policy performance indicators is however a challenge (Marcot et al., 2012; Niemeijer et al., 2008; Failing et al., 2003), especially when policy targets are not specifically defined and do not allow direct translation into measurements (e.g. Which variables identify "sustainably managed" forest areas? or: Which variables identify "natural" forest areas?). In Chapter 1.1, history has shown that this was particularly the case where policies addressed fuzzy issues that may be understood in 
various ways. Concerning topics such as biodiversity (under UN CBD, Habitats Directive) and sustainable forest management (under UNFF), policy makers were often unsure about their strategic goals or they had very different opinions which meant that lack of compromise and absence of clearly formulated and agreed definitions hindered consent on targeted attributes and threshold values. In such cases policy makers usually agreed on vague policy targets which are difficult to measure by statistically-based inventory programmes.

The first objective of this thesis research was to support future inventories and monitoring programmes by identifying data needs at two stages of the science-policy interface as illustrated in Figure 2:
(A) Monitoring and reporting
(B) Interpretation and decision making

Table 1 shows that at both stages, three questions were interesting from an inventory perspective.

(1) What were the required attributes?

(2) What were the required quality characteristics?

(3) Which authorities were the most trusted data providers?

These questions are essential to better understand the current value of information for forest related decision making processes and to identify options to improve measurement methods, sampling- and assessment designs. More details and definitions on the abovementioned points (A, B and 1,2,3) will follow later, in the description of methods (Chapter 2).

Table 1. Research objective 1 - Answering the question of data relevance (the letters "A" and "B" refer to the bipolar process described in Figure 2)

\begin{tabular}{|l|l|}
\hline & Q 1 Relevance \\
\hline $\begin{array}{l}\text { (A) } \\
\text { Monitoring and reporting }\end{array}$ & $\begin{array}{l}\text { 1. Attributes } \\
\text { 2. Quality } \\
\text { 3. Providers }\end{array}$ \\
\hline $\begin{array}{l}\text { (B) } \\
\text { Interpretation and decision- } \\
\text { making }\end{array}$ & $\begin{array}{l}\text { 1. Attributes } \\
\text { 2. Quality } \\
\text { 3. Providers }\end{array}$ \\
\hline
\end{tabular}




\subsubsection{Risk of political bias}

History on forest policy and the development of indicator processes further teaches that formally, scientific information is in high demand (cf. Chapter 1.1). Yet, Chapter 1.2 has shown two scenarios where scientific engagement in the political domain may be perceived as political advocacy, thus posing a serious threat to credibility:

(1) If policy-makers instrumentalise scientific ideas to support a political agenda, then scientists may unknowingly become political advocates, even though the origins of political bias lay within the political domain.

(2) Whereas in another scenario, if scientists actively influence research output to support a favored political argument, then the origin of political bias lies within the scientific domain and scientists knowingly become advocates. Either case scenario may be harmful to scientific reputation.

The second objective of this study was to make scientists aware of the associated risks, at the two stages of the political decision making process:

(A) Monitoring and reporting processes (mainly a scientific responsibility)

(B) Interpretation and decision making processes (mainly a political responsibility)

Table 2 shows that at both stages, the research objective was to test the theory of political bias by analysing 2 conditions:

1. Political motivations and

2. Lack of transparency

The analysis of the two conditions verifies if political motivations exist and if non-transparent assessment methods could possibly allow them to tacitly influence assessment results.

Further addressing the question of a risk of political bias at both stages of the monitoring and decision-making process, i.e. during science-based monitoring and reporting, and during political interpretation, in this study, my analysis shall eventually help to locate the origin, thus answering the question if bias may be attributed to the scientific, or rather to the political community. The objective here is not to blame the respective disciplines but to identify issues that may limit credibility and legitimacy of both, politics and science. Pointing out these 
issues, this thesis seeks to contribute to making the science-policy interface more transparent and support well-informed and democratic decision-making processes.

Table 2. Research objective 2 - Answering the question of political bias

\begin{tabular}{|l|l|}
\hline & $\begin{array}{l}\text { Q 2 Risk of political bias } \\
\text { (confirmed under 2 } \\
\text { conditions) }\end{array}$ \\
\hline $\begin{array}{l}\text { (A) } \\
\text { Monitoring and reporting }\end{array}$ & $\begin{array}{l}\text { 1. Political motivation } \\
\text { 2. Lack of transparency }\end{array}$ \\
\hline $\begin{array}{l}\text { (B) } \\
\text { Interpretation and decision- } \\
\text { making }\end{array}$ & $\begin{array}{l}\text { 1. Political motivation } \\
\text { 2. Lack of transparency }\end{array}$ \\
\hline
\end{tabular}




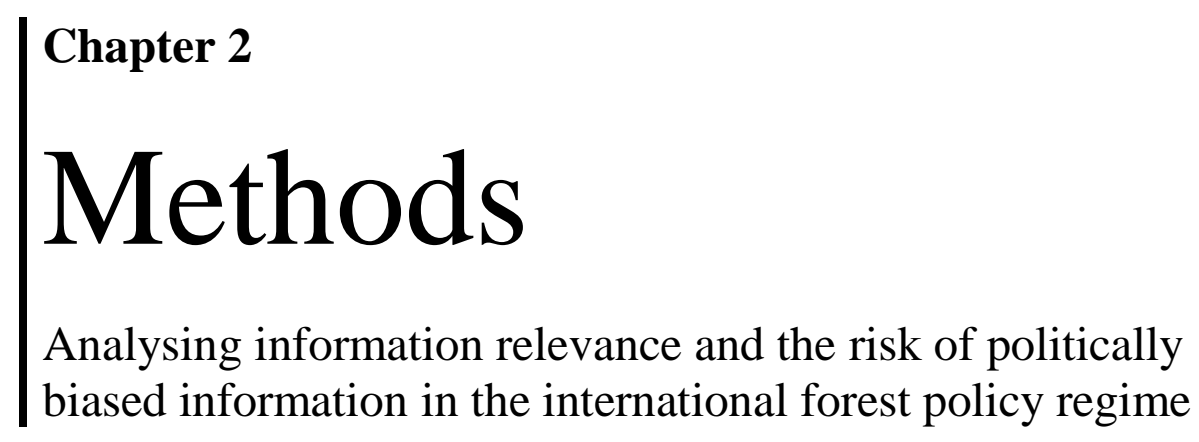




\subsection{Selection of case-studies}

As explained as a part of my research objectives and shown in Table 3, this study looks at the relevance (Q 1) and potential bias (Q 2) of forest information. The analysis addresses three different spatial scales that coincide with the hierarchy of the international forest policy regime: The "Global", the "European" and the "National". Europe was chosen as a regional example because the idea of global reporting and policy processes, specifically the UN-FAO criteria and indicators for sustainable forest management, originated in Europe's MCPFE. I further select 3 countries for case studies at the national level: Germany, Poland and Sweden. The reason is that from a political perspective, all of them are subject to similar international forest management regulations and reporting commitments under UN- and EC policies (UNFF, UNCBD, UNFCCC, EC Habitats Directive). From an environmental perspective, with an estimated forest cover of about 30 percent, Germany (32.8\%) and Poland (30.8\%) are further comparable to most of the other European member states. Sweden in contrast stands out from most of the other EU-member states because it has a comparably large forest cover (68.4\%) (Forest Europe, 2015) and it covers the mostly inaccessible boreal biogeographical region (ETC/BD, 2006) which might host forest areas that are not easily reached for ground-based measurements. Due to the importance of forestry in Sweden that is combined with the challenges of sparse infrastructure and inaccessible terrains, especially in the boreal regions (Angelstam et al., 2004), we might expect that forest monitoring programmes are advanced and well developed in order to better meet the information needs of forest policy. The strong research focus of forest monitoring authorities leads to similar conclusions (cf. list of publications in: SLU, 2017). The Swedish case study therefore seeks to derive ideas on how to improve inventory programmes in other countries to better meet political information demand. As shown by Table 3, each of the described national case studies is selected for different chapters of this thesis:

Chapter 3 analyses national decision-making processes by example of a German case-study. The analysis looks at the parliamentary discourse on the amendment of the National Forest Act (BWaldG) in 2010. A national discourse is selected because it is often national policies and experiences of member states that act as a role model (UNCSD, 2012) and thus lay the foundation for wider political discourse on larger-scale policy agreements on the global level. The German discourse on the national forest-act was of such global relevance because it sought to enforce international policies of major importance for the international forest policy regime complex, specifically those of UNFF and it endeavours to implement legally binding management standards. But also other recent political ambitions regarding biodiversity 
conservation and carbon-sequestration under UNCBD and UNFCCC (cf. Chapter 1.1) were part of the discussions. Beyond the aspect of global forest policy, the German discourse was also of major significance from the perspective of scientific information generation, the reason being that politicians did not only seek to implement the above-mentioned policies, but they also worked towards the extension of the national monitoring mandate such as to lay the foundation for informing future policies. Finally, a practical advantage of selecting the German discourse as a case-study was its comprehensive documentation which allowed an all-inclusive analysis of political backgrounds, regarding today's forest policy and monitoring mandates. A similarly comprehensive documentation of political discourses on recent topics of the global forest policy regime could not be found elsewhere in policy-processes on other spatial scales. For that reason, this study selects only a national, no European or global, example as a case study for political information selection and potential risks of political bias (Table 3).

Regarding the organisation of chapters, and coinciding with the top-down order of precedence in Table 3, the German case will be subject to analysis first. The reason is that the other case studies and their findings on European and global monitoring processes can be understood best as a result of the German parliamentary discourse and its decision on the new monitoring mandate.

Then, within the second and third case studies (Chapters 4 and 5), I analysed information requirements and potential sources of bias in international monitoring and reporting processes. For this purpose I selected national, European and global reports submitted under two obligations: Article 17 of the European Habitats Directive, and Article 7 of the UNCBD.

The two reporting obligations under the European Habitats Directive and UN-CBD were selected as examples for politically influential reporting process, because both these policies formulate legally binding policy targets. This means that, legally, they form a contract where parties agree and commit themselves to common goals. The legal implications of such binding polices on the mandate and the political importance of forest inventories become evident by the excursus presented in Box 4. It describes the process of international treatymaking and the domestic obligations resulting from such treaties. Using the example of the prosecution of Germany by the European Commission and the Ruling of the European Court of Justice, the excursus further illustrates the legal consequences of infringement and the power of scientific information for enforcement of international law. 
The example shows that for the purpose of enforcing international agreements by legal measures, it is, crucial to have precise and accurate information that allows assessment of compliance and enforcement of international law (e.g. inventories of Annex I habitats and inventories of their respective national protection status). Members of the EU Habitats Directive and the CBD have therefore agreed to legally binding reporting obligations. Monitoring programmes and inventories used in such reporting processes are therefore highly relevant from a political perspective, and also to my thesis.

This is somewhat opposed to data reported by FAO under the global FRA. The reporting framework has been set up in order to inform ongoing discussions on the necessity of international legally binding management regulations for SFM (cf. Chapter 1 on history). SFM is currently defined by the non-legally-binding "forest instrument" and the C\&I- process of FAO, but the parties of the UNFF have not yet agreed to translate the SFM definition into a legally-binding set of management rules . The reporting process of FAO is thus important for future discussions, but as the rules are not yet mandatory, states are not obliged to issue monitoring mandates and they may even choose not to report at all. In such a case of absent or incomplete reports it would be impossible for my study to answer the two questions that were defined in Chapter 1, namely: (1) politically relevant sources and (2) the risk of political bias within these sources.

Table 3. Research structure. At the left, the table shows the stages of the data generation- and decision-making processes. The top-row heads the selected case studies and the research questions addressing each of the respective stages.

\begin{tabular}{|c|c|c|c|c|c|}
\hline & & Case study & Q 1 Relevance & $\begin{array}{l}\text { Q } 2 \text { Risk of political bias } \\
\text { (confirmed under } 2 \\
\text { conditions) }\end{array}$ & \\
\hline $\begin{array}{l}\text { Interpretation } \\
\text { and decision- } \\
\text { making }\end{array}$ & National & German parliament & \multirow{4}{*}{$\begin{array}{l}\text { 1. Attributes } \\
\text { 2. Quality } \\
\text { 3. Providers }\end{array}$} & \multirow{4}{*}{$\begin{array}{l}\text { 1. Political motivation } \\
\text { 2. Non-transparency }\end{array}$} & Chapter 3 \\
\hline \multirow[t]{3}{*}{$\begin{array}{l}\text { Monitoring and } \\
\text { reporting }\end{array}$} & National & $\begin{array}{l}\text { Article } 17 \text { Habitats } \\
\text { Directive } \\
\text { (reports by SE, DE) }\end{array}$ & & & Chapter 4 \\
\hline & Europe & $\begin{array}{l}\text { UN-CBD } \\
\text { (report by EC) }\end{array}$ & & & Chapter 5 \\
\hline & Global & $\begin{array}{l}\text { UN-CBD } \\
\text { (report by UN) }\end{array}$ & & & \\
\hline
\end{tabular}


The UN treaty making process follows the regulations laid down by Articles 10 and 18 of the Vienna Convention on the Law of Treaties (1969). It stipulates that the parties of a consortium initially sign the document to express their common goals, that they are generally willing to comply with the agreements and that they plan to continue the treaty-making process. Then, the ratification is an international act whereby every individual state agrees to be bound to that treaty and its regulations (ratification procedure laid down in: Arts.2 (1) (b), 14 (1) and 16, Vienna Convention on the Law of Treaties 1969; or cf. also: UN, 2018).

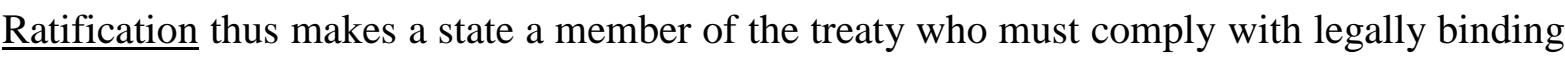
obligations. After the ratification process the ratifying institution allows parties a timeframe to seek domestic approval and to translate international agreements into national legislation. Failing to give domestic effect to that treaty or to violate its regulations would mean a breach of contract which usually leads to measures of justice such as penalty payments imposed by the European Commission.

This has happened to Germany in 2001, when the European Court of Justice ruled that Germany did not comply to its obligations of Habitats Directive Article 4 (1), subparagraphs $1-2$, when it failed to report, within the prescribed period, a complete list of sites with information on the area of Annex I-habitats that shall be protected under Article 1 of that directive. Germany, however, defended the validity of its actions by appealing to its margin of discretion when identifying and selecting sites for inclusion in the list (a right granted by Article 4(1) of and Annex III to the directive). The European Court of Justice acknowledged that argument but it ruled that within the process of identification and selection of sited to be reported "only criteria of a scientific nature may guide the choice of the sites to be proposed" and that "the sites proposed must provide a geographical cover which is homogeneous and representative of the entire territory of each Member State" (European Court of Justice, judgment of 11. 9. 2001 - CASE C-71/99, paragraph 20).

According to the judges, Germany violated that rule due to two reasons: (1) by the deadline of submission, the German list did not cover its full territory because some of the Federal States refused to report, (2) Criteria for site selection were too vague and did not match the criteria defined by the BfN handbook "Das europäische Schutzgebietssystem Natura 2000" $(\text { Ssymank, 1998) })^{14}$.

\footnotetext{
14 "The Commission states that it instituted the present proceedings with a view to securing a declaration that the German national list was manifestly inadequate, and that such inadequacy far exceeded the margin of discretion conferred on Member States. Such inadequacy is evident with regard to the situation existing when the period set in the reasoned opinion expired, and even though the German authorities have, since then,
} 
Box 4. Excursus on the treaty making process, legal implications and the importance of scientific information by example of the ruling of the European Court of Justice on 11. 9. 2001 - CASE C-71/99

Besides choosing only such legally binding forest polices as case studies, I further decided to select policies with a focus on biodiversity. The reason is that biodiversity assessments are technically challenging and fairly new in forests, where traditionally, inventories have been more targeted towards the assessment of economically tradable resources. A prominent example are volume-based estimates of timber stocks and carbon sequestration, both tradable, either on the timber- or the carbon market (cf. Ch. 1). Measurement of data on the relatively new topic of biodiversity is however, challenging for NFIs. Analysis of new political reporting obligations on biodiversity in forests may thus provide up-to date information on what kind of evidence is moving into political focus recently and how to solve the emerging technical and political challenges.

Finally the topic of biodiversity is also interesting from a policy research perspective because ideas on biodiversity conservation are often laden with ideological values and political controversies. Any option to instrumentalise such data politically, i.e. to select data or skew results towards a politically favoured outcome could therefore be enticing for policy-makers. As shown in Table 3, column Q 2, such discussions on the risks of political bias will form the second analytic part this thesis.

forwarded several other lists of sites, the infringements of which they stand accused still persist. The Commission submits in this connection that a comparison between the proposals of the German authorities and the scientific data provided by those authorities, in particular the manual entitled 'Das europäische Schutzgebietssystem Natura 2000' edited by the Bundesamt für Naturschutz (Federal Office for Nature Protection) amply demonstrates the true nature of those infringements. The German national list does not therefore, in the Commission's opinion, satisfy the criteria referred to in Article 4(1) of the directive, read in conjunction with Annex III thereto." (European Court of Justice judgment of 11. 9. 2001 - CASE C71/99,paragraph 21) 


\subsection{Relevance}

\subsubsection{General considerations on measuring "relevance" and the method of}

guided literature research

I have already mentioned the first research objective which was to identify political data requirements. True requirements are however difficult to identify and this is a challenge for the definition of research methods. Common methods are to directly question selected members of a sampled population about their needs, either by expert interview (Hickey et al., 2005; Runge et al., 2011) or by a standardised questionnaire (Janse, 2006, 2008; Hickey et al., 2007). Both methods are problematic, especially when interviewees are also stakeholders within political settings. Then, political interests may lead to answers that are incomplete (Armstrong and Overton, 1977) or not completely honest (Holbrook et al., 2003). If asked for data requirements for instance, the data user could try to present himself a good decision maker by falsely claiming that he had very high expectations, even though he actually favoured cheaper data with less precise information. In such cases, it would become extremely difficult to distinguish the truth from the lie.

To exclude such error, I develop a novel approach as an alternative to qualitative or quantitative interviews. I analyse the characteristics of data that was actually being demanded by an obligation (receiver's requirements, mostly political community) or used within the reporting process (provider's requirements, mostly scientific community). My analysis follows the assumption that data was reported only when it was relevant, i.e. when it was regarded good enough to meet minimum requirements. It should be noted however, that such requirements can be difficult to satisfy. If data is not available at a given precision level, then reporting processes may use lower-quality information instead. Data-use is then a compromise between the receiver's requirements and availability. Yet, we may assume that data-use reflects at least the minimum requirements. Compared to expert-interviews, the method's biggest advantage is a largely unbiased reflection of true political requirements. This is especially the case in politically sensible topics such as quality standards and decision making. To my knowledge no study has ever used such an approach to quantify the political impact of monitoring programmes.

In order to acquire the relevant materials and documents on the national data providers and their variables and inventory methods, I make a guided literature research. In my approach, I start with the documented political information as a key-document. In the case-study on the 
parliamentary discourse (Chapter 3), such key documents include plenary statements or assumptions about forest facts. In the case studies on national (Chapter 4), European and UNreports (Chapter 5) the respective reports are taken as key-sources. These provide references to other sources and eventually allow inferences on background methods of data analyses and measurements. More information and detailed descriptions of the types of consulted documents follow later (Chapters 2.2.2-2.2.4). Below, I introduce these sections by an explanation of how the issue of "data relevance" is defined for the purpose of this study.

\subsubsection{Defining "data sources" and assessing political relevance of the three components: "attributes", "quality" and "providers"}

Data sources may be defined in many different ways. It is possible to refer to a "data source" as an inventory as a whole, such as an NFI, forest soil inventory and forest health inventory. However, if we look at the composition and set-up of such programmes then it makes sense to use a definition that reflects that composition. Generally speaking, it is not sufficient to refer to the data source as the providing authority only. The reason is that data might be provided by one individual authority, yet there are usually many different variables available, where each is assessed by different methods and with different levels of accuracy and precision. To account for this diversified nature of a "data source", my thesis differentiates three different components that may also be of different relevance to policy-makers:

(1) the attribute of a variable,

(2) data quality and

(3) providers.

When analysing the relevance of these components, then politically relevant "attributes" are identified by definitions of legal monitoring mandates, reporting guidelines and inventory manuals. The second component of requirements, i.e. data quality, is defined in a more general sense than in statistical terms. It is seen as any type of data characteristic or content that might explain choice of information. Such a broader perspective is important, because stakeholders, especially political ones who do not have statistical training, may have a very different understanding of quality requirements than statisticians. The third component to be analysed, the politically preferred data providers, are identified as the authorities that 
contributed to a given source: ranging from those involved in measurements, to those doing analysis and report compilation.

Table 4 shows that the three components are to be assessed at two stages of the decisionmaking process: (A) technical monitoring and reporting, and (B) political interpretation and decision making. The difference of materials available at each of these stages is, however, a methodological challenge: Reporting processes are mainly documented by reporting formats and guideline documents. Using the method of guided literature research these key-documents therefore allow direct reference to attributes and technical quality requirements, while political discourse was more often of a qualitative nature. Documents such as stenographic records and parliamentary publications reflected the argumentative discourse but they rarely provided direct reference to technical requirements. In order to overcome this issue and to actually provide insights into technical data needs my analysis needs to adapt its methodology accordingly. The following sub-sections provide a brief overview of material and methods used within the individual case-studies.

Table 4. Research structure for assessment of relevance of information (research question 1). At the left, the table shows the stages of the data generation- and decision-making processes. They are in the order of this work's analysis (first B then A). The right columns show the selected case studies and the 3 criteria assessing data relevance at each of the respective stages.

\begin{tabular}{|l|l|l|l|l|}
\hline \multicolumn{2}{|l|}{} & Case study & Q 1 Relevance & \\
\hline $\begin{array}{l}\text { Interpretation } \\
\text { and decision- } \\
\text { making }\end{array}$ & National & German parliament & & Chapter 3 \\
\cline { 1 - 3 } $\begin{array}{l}\text { Monitoring and } \\
\text { reporting }\end{array}$ & National & $\begin{array}{l}\text { Article 17 Habitats } \\
\text { Directive } \\
\text { (reports by SE, DE) }\end{array}$ & $\begin{array}{l}\text { 1. Attributes } \\
\text { 2. Quality }\end{array}$ & 3. Providers \\
\cline { 2 - 3 } & Europe & $\begin{array}{l}\text { UN-CBD } \\
\text { (report by EC) }\end{array}$ & Chapter 5 \\
\cline { 2 - 3 } & Global & $\begin{array}{l}\text { UN-CBD } \\
\text { (report by UN) }\end{array}$ & \\
\hline
\end{tabular}




\subsubsection{Parliamentary discourse}

Data requirements of national-level decision making processes are evident from the parliamentary discourse on the 2010 amendment of the national forest act of Germany (BWaldG). The discourse is documented by the Parliamentary Material Information System (DIP) of the German Bundestag (Federal Assembly) which lists all official documents by legislative process. The documents include "letters of enquiry to the government" and "governmental responses", "plenary protocols" and so-called "printed matters" (p.m.). In combination, they provide a comprehensive overview of what has been discussed in- and outside the plenary sessions. Plenary protocols further include direct speech and descriptions of emotional reactions, which allows accurate conclusions on the politically perceived relevance and trustworthiness of information. These described expressions provide the unique opportunity to study the user's objectives and the role of political consent or dissent in data choice.

Using these documents as key-references, I first elaborate the political arguments, objectives and conflicts in discourse. I then quantify politically required attributes and variables by the statements and supporting evidence on forest facts that supported these objectives. Finally, the parliamentary decisions made in the end of discourse allow conclusions on those data characteristics that successfully enforced political arguments and eventually convinced the parliament.

Table 4 shows that quality requirements are the second criterion to be analysed when looking at the political relevance of data. Quality needs in terms of statistical accuracy and precision were not mentioned in the parliamentary discourse. For this reason, I identify quality requirements by: technical measurement methods of quoted evidence (such as sampling design) and by the level to which a given reference had been aggregated and condensed. Figure 3 shows an example where such different levels of data aggregation might either be measured variables (tree height in meters), results of analysis algorithms (volume growing stock per ha) or condensed interpretations ("Germany has high timber resources"). Characterising each quoted evidence by its respective level of aggregation and condensation eventually helps to identify the type of presentation that was most relevant, understandable or trustworthy policy-makers.

Data providers are to be elicited in a third step. They were either evident from the quotation itself or from other references elsewhere in the parliamentary documents. As I will show, 
identifying providers comprehensively was often a challenge, especially when parliamentarians did not refer to an inventory authority but to summarising reports. In these cases, using the method of guided literature research, I retrace the chain of data generation: back from the parliamentary statement, to the documented source, its different stages of analysis, and its original measurements. This method provides a comprehensive overview on all providers and authorities involved in the data generation process.

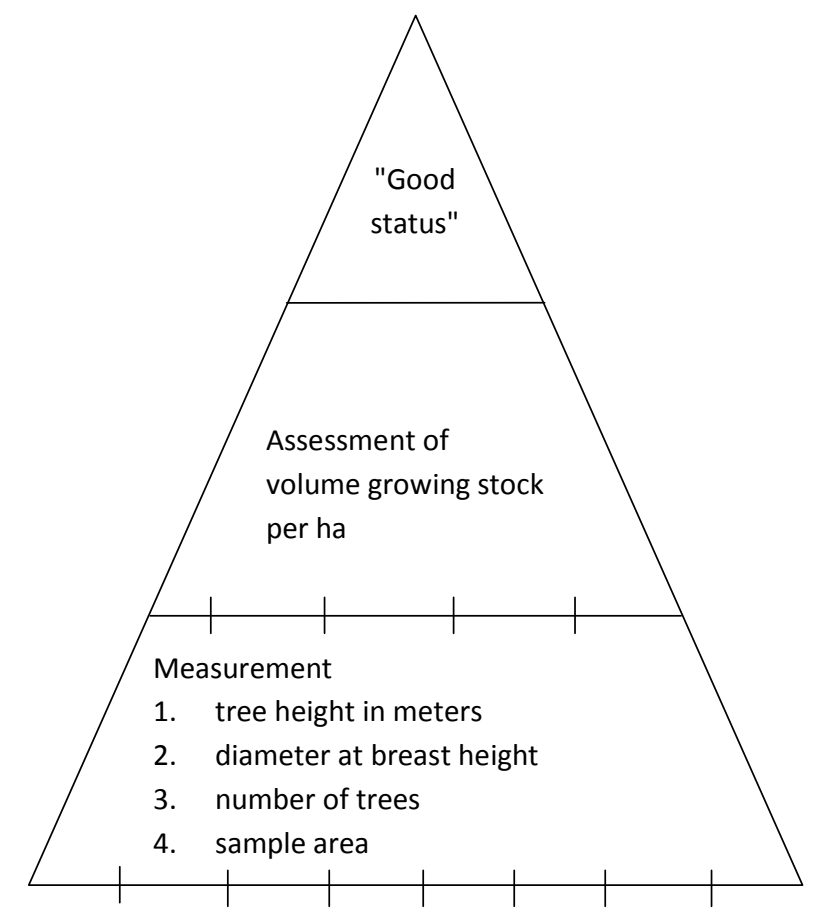

\section{Interpretation (qualitative)}

Policy performance by comparison against

a target value or interest

Analysis (quantitative)

Assessment algorithms

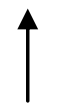

Measurements (quantitative)

Variables, plot- and sampling design

Figure 3. Level of aggregation of information as a quality characteristics in political discourse

\subsubsection{Reporting processes}

For case studies on national and international reporting processes, data requirements are acquired from different key-documents. In Germany and Sweden political data needs become evident from national reports, monitoring guidelines, data compilation algorithms and fieldmanuals. These documents are mainly available via the European Environment Agency's online "European Environment Information and Observation Network" (EIONET) with its Reporting Obligations Database (ROD), a platform for data-exchange between providers and users. A similar database is used to acquire key-reports for the case study on the European 
Commission. The $5^{\text {th }}$ European biodiversity report to the UNCBD is published in the format of a digital online database within the Biodiversity Information System for Europe (BISE, 2017). In both databases, upload is restricted to reporting authorities and therefore authenticity and timeliness of my background materials is guaranteed. As for the UN biodiversity report under UN-CBD obligations, data was being published as a printed version only, the " $4^{\text {th }}$ Global Biodiversity Outlook" (GBO4) by Leadley et al. (2014). Within these documents, I identify and quantify political data requirements using the number of different cells to be filled out in the respective report forms.

The extractable information of key-documents however is mainly restricted towards politically required attributes and variables, without information on technical requirements regarding data quality and assessment methods. Comprehensive acquisition of all relevant quality criteria and providers, including information on national monitoring methods is eventually a challenge, especially because many different authorities were involved into the process, ranging from those compiling the report, to those doing analysis and measurements. For a more comprehensive overview, I therefore use again the method of guided literature research. In this method, I use the final national report as a key document. That document then directs me towards methods of data analysis, the original input variables and field-based measurements. If evident from the background materials, I then identify quality requirements from achieved measures of precision. Alternatively, national monitoring and reporting methods are an implicit source of technical quality standards at 3 levels: 1) Measurement methods, 2) Sampling and plot design and 3) Analysis algorithms. The third criterion to be assessed in the present study, i.e. the policy relevant "data providers", is analysed at all stages of the reporting process, ranging from field measurements, assessment methods, to report compilation.

\subsection{Risk of political bias}

\subsubsection{General considerations}

I mentioned before that the second research target of this thesis was to identify the risk of political bias. As shown in Table 5, this analysis differentiated two different domains: the domain of science, which comprises monitoring and reporting responsibilities at the European and the Global levels, and the domain of policy-making which comprised interpretations in the decision making process of a parliamentary discourse. 
The selection of analytical tools follows political theory (Krott, 2012; Krott et al., 2014; Pregernig, 2007; Hertin et al., 2009; Haas, 2004; Pielke, 2007) as presented in Chapters 1.2 and 1.3. In that theory, the general assumption was that political interests motivate policymakers and/or scientist to select non-transparent methods that allow tacit, i.e. hidden bias of assessment results towards a favoured outcome.

Consequently, as shown in Table 5, risk of political bias bases on two conditions:

1) "Political motivations" (rather than scientific ones)

2) "Lack of transparency" (rather than transparency)

My method wants to validate these two assumptions in a step-by-step approach. First, I identify motivations of actors involved in monitoring and decision-making. This also includes a discussion on political motivations and an analysis identifying potential conflicts between political motivations and scientific responsibilities. In a second step, I evaluate if nontransparent assessment methods really allowed these political motivations to influence, i.e. bias, assessment results towards a politically favoured outcome.

Table 5. Research structure for assessment of the risk of political bias (research question 2). At the left, the table shows the stages of the data generation- and decision-making processes. They are in the order of this work's analysis (first B then A). The right columns show the selected case studies and the 2 instruments assessing risk of political bias at each of the respective stages.

\begin{tabular}{|c|c|c|c|c|}
\hline & & Case study & $\begin{array}{l}\text { Q } 2 \text { Risk of political bias } \\
\text { (confirmed under } 2 \\
\text { conditions) }\end{array}$ & \\
\hline $\begin{array}{l}\text { Interpretation } \\
\text { and decision- } \\
\text { making }\end{array}$ & National & German parliament & \multirow{4}{*}{$\begin{array}{l}\text { 1. Political motivation } \\
\text { 2. Non-transparency }\end{array}$} & Chapter 3 \\
\hline \multirow[t]{3}{*}{$\begin{array}{l}\text { Monitoring and } \\
\text { reporting }\end{array}$} & National & $\begin{array}{l}\text { Article } 17 \text { Habitats } \\
\text { Directive } \\
\text { (reports by SE, DE) }\end{array}$ & & Chapter 4 \\
\hline & Europe & $\begin{array}{l}\text { UN-CBD } \\
\text { (report by EC) }\end{array}$ & & \multirow[t]{2}{*}{ Chapter 5} \\
\hline & Global & $\begin{array}{l}\text { UN-CBD } \\
\text { (report by UN) }\end{array}$ & & \\
\hline
\end{tabular}


It is to note that my analysis validates only assumptions of a theoretical concept. As such it assumes that stakeholders may possibly exploit options of influence if it servers their benefit. Yet, if these options were actually used remains difficult to prove, especially because I can only derive assumptions on political motivations (e.g. via stakeholder responsibilities) but I cannot ascertain the precision of my predictions. In fact, it is difficult to look into people's heads and certainty is difficult to reach in variable and fuzzy subjects such as human motivations that are difficult to measure and predict. The same is true for the many components influencing human ambitions, such as political culture (Hellström, 2000), and traits of the individual such as intuition (Khatri et al., 2000) and emotion (Sayegh et al. 2004). The first analytic assumption, i.e. political motivation is therefore an elusive concept that is difficult to grasp by standardized and quantitative methods. Therefore, my analysis may identify only few of the many components that might possibly explain stakeholder motivations. Indeed, other than strengthening oneselves political position or reputation, more positive motivations such as ideologies and an honest interest in scientific evidence and well informed decision-making may also shape data selection. A discussion of these more positive motivations will therefore complement the results of the respective case-studies.

As shown in Table 5, the second criterion to be analysed was the political utilisation of nontransparent information. The assumption is that low quality standards such as non-transparent assessment rules may come from the political motivation to hide unwanted information or to influence data in different ways. It is to note that also this string of argumentation does not always provide the full picture. Lack of transparency would only provide theoretical options of tacit influence, if policy makers really used such options, remains difficult to prove. Alternatively, absence of better quality data or practical difficulties to implement samplebased and standardised inventory designs could also explain choice of non-transparent assessment methods. Eventually, this study cannot make any certain and robust statements on political bias. Instead, it identifies risks of political influence and warns scientists of the associated threats to credibility.

\subsubsection{Parliamentary discourse}

In the case study on the German parliament I analyse the risk of political bias by initially identifying motivations of the political parties. Analysis is based on records of the spoken or written discourse. Herein I differentiate two different kinds of motivations: (1) explicit objectives voiced openly during the parliamentary discourse and (2) implicit, i.e. tacit 
objectives which are not openly voiced, but which become evident by the practical consequences of decisions. I study these consequences by juridical methods, i.e. I explain how politically favoured decisions affected other legal acts that regulate real-world problems. These regulations are interesting because they may benefit certain groups that lobby for political influence, such as the timber sector, or biodiversity conservation groups. The advantage of assessing these implicit consequences of decisions is that it eventually allows very precise conclusions about political motivations, whereas openly voiced objectives could merely be a political means of disguising the truth.

In a consecutive step, I assess the extent to which non-transparent interpretations actually allowed these political motivations to influence decisions. At this stage, interpretations are assumed to be non-transparent when a statement about forest facts is found to be without verifiable evidence. In such a case the statement would merely be an unconfirmed assumption. This could turn to a real problem in democratic decision-making processes because the public may not verify such assumptions. It then becomes impossible to make own interpretations or to join the democratic discourse as to what would have been an optimal decision. My analysis thus seeks to contribute knowledge to the status of democracy in decision-making processes.

\subsubsection{Reporting processes}

When I assessing the risk of political bias in the monitoring and reporting process, I use the same analytic tools as I have done previously in the parliamentary discourse:

1) Political motivations and

2) Lack of transparency.

Yet, the background materials are different and I slightly change the methodology of quantifying gaps in the provision of transparent information such as to allow analysis of the background materials. The materials were acquired from international reporting processes according to the methodology of guided literature research described in Chapter 2.2.4 and comprise official national reports of Germany and Sweden as well as European and UNreports. These documents cover information on data acquisition and inventory methods of actors involved in all stages of monitoring and reporting process: From measurements, to assessment methods and report compilation. 
In an initial step, I identify motivations of those involved in technical data acquisition and analysis. That analysis observes involved stakeholders, their scientific activity and their administrative responsibilities. The advantage of identifying motivations via responsibilities is the ability to discover hidden interests that are not openly voiced but that become evident from the practical consequences. Again, the intention is to identify responsibilities and interests that could come into conflict with scientific and transparent methods of data acquisition.

In a subsequent step, I assess the extent to which non-transparent data acquisition methods allowed these political motivations to influence reports. I quantify the extent by the number values submitted in each national report.

Methods are assumed to be non-transparent in two cases: 1) assessment rules are absent, or 2) rules are vaguely defined. Vague rules include for instance sampling designs that do not define the exact location and size of a sample plot. Vague rules also include measurements of variables without a definition of scale or indicators that do not have a threshold value to indicate the measurement target. In such cases, different interpretations were theoretically possible. There was at least an option for stakeholders to select those sample locations, scales or threshold values that provide preferred output results. By comparing my previous evidence on political motivations with the options of political influence, I can eventually conclude if there was a theoretical risk of political motivations to influence results. 
Chapter 3

Case Study

Fragmentation in the political discourse 


\subsection{Review of rationale and objective}

The 2010 amendment of the Federal Forest Act was probably one of the most important political discourses on national forest policy in Germany, because it sought to implement major international agreements of the international forest regime-complex (Habitats Directive, CBD, UNFCCC and UNFF), into legally binding regulations (cf. Ch. 1.1.6). In this chapter, I therefore took the parliamentary discourse as a case-study of political data use and decisionmaking. Table 6 shows that, same as for all other case studies of this thesis, also this chapter looked at two research questions:

(Q1) The relevance of forest information with respect to: 1) attributes, 2) quality and 3) most trusted providers.

(Q2) The risk of political bias was verified by two analytic tools: 1) political motivations and 2) transparency of information (Table 6).

Table 6. Research questions to be answered in this thesis (the part to be analysed in this chapter is highlighted by bold frame)

\begin{tabular}{|c|c|c|c|c|c|}
\hline & & Case study & Q 1 Relevance & $\begin{array}{l}\text { Q } 2 \text { Risk of political bias } \\
\text { (confirmed under } 2 \\
\text { conditions) }\end{array}$ & \\
\hline $\begin{array}{l}\text { Interpretation } \\
\text { and decision- } \\
\text { making }\end{array}$ & National & German parliament & $\begin{array}{l}\text { 1. Attributes } \\
\text { 2. Quality } \\
\text { 3. Providers }\end{array}$ & $\begin{array}{l}\text { 1. Political motivation } \\
\text { 2. Non-transparency }\end{array}$ & Chapter 3 \\
\hline \multirow[t]{3}{*}{$\begin{array}{l}\text { Monitoring and } \\
\text { reporting }\end{array}$} & National & $\begin{array}{l}\text { Article } 17 \text { Habitats } \\
\text { Directive } \\
\text { (reports by SE, DE) }\end{array}$ & $\begin{array}{l}\text { 1. Attributes } \\
\text { 2. Quality } \\
\text { 3. Providers }\end{array}$ & $\begin{array}{l}\text { 1. Political motivation } \\
\text { 2. Non-transparency }\end{array}$ & Chapter 4 \\
\hline & Europe & $\begin{array}{l}\text { UN-CBD } \\
\text { (report by EC) }\end{array}$ & $\begin{array}{l}\text { 1. Attributes } \\
\text { 2. Quality } \\
\text { 3. Providers }\end{array}$ & $\begin{array}{l}\text { 1. Political motivation } \\
\text { 2. Non-transparency }\end{array}$ & \multirow[t]{2}{*}{ Chapter 5} \\
\hline & Global & $\begin{array}{l}\text { UN-CBD } \\
\text { (report by UN) }\end{array}$ & $\begin{array}{l}\text { 1. Attributes } \\
\text { 2. Quality } \\
\text { 3. Providers }\end{array}$ & $\begin{array}{l}\text { 1. Political motivation } \\
\text { 2. Non-transparency }\end{array}$ & \\
\hline
\end{tabular}




\subsection{Materials}

The available documents of the legislative procedure are source for reconstructing and analysing the parliamentary process. These were readily accessible from the Parliamentary Material Information System (DIP) of the German Bundestag (Federal Assembly) which lists all official documents by legislative process. The documents include "letters of enquiry to the government" and "governmental responses", "plenary protocols" and so-called "printed matters" (p.m.). Letters of enquiry come from political parties or other stakeholders. They may request information on the status of policy implementation or they may request for reasons of a specific policy. The government then reports by so-called "governmental responses". "Plenary protocols" contain stenographic reports on each parliamentary discussion. These protocols are in the form of direct speech, including emotional reactions such as laughter and other spontaneous reactions. For my analysis, the major benefit of such spontaneous and usually uncontrolled reactions was that they provided the unique opportunity to study the policy-makers' true and unfiltered opinions and believes. It thus provided most accurate evidence whether a member of parliament personally viewed an opponents claim or information on forest facts as reliable and trustworthy.

Besides the enquiries to the government, its responses and the plenary protocols, a further source of information comprised printed matters. These are official documents explaining parliamentary decisions and the political reasons for such decisions. They provide the opportunity to study political backgrounds that were known to parliamentarians but not discussed during plenary sessions. Finally, it is to note that, in order to make sure that my evidence reflected the current situation, it was important to select only documents with a specific reference date. Hence, I used laws and definitions as valid during the course of the legal dispute (reference date mostly 2010). These laws partly differ from those valid at the time of writing and publishing of this thesis.

For analytic purposes, the documents will be arranged in the chronological order of parliamentary disputes: Formally, in Germany, the legislative process starts with a legal draft that needs to run through all stages of the legislative process before enactment. The submission of legal drafts is regulated in Article 76 of the Federal Constitution (Grundgesetz). It allows the Cabinet of Germany, the Bundesrat (Federal Council) and the members of the German Bundestag (Federal Assembly), to submit draft acts. If a member of parliament plans to make a submission, the draft needs a support of at least $5 \%$ of the parliament members. Then, the Bundestag has to discuss the draft in a regulated legislative procedure. 
Alternatively, members of parliament may request the Cabinet to submit a draft act. This was the case in the amendment of the Federal Forest Act.

As required by constitution, these draft acts were read and discussed three times in parliament. During that process, members made recommendations and requests regarding amendments. Eventually, on the third reading, the parliament took a vote, where the draft got a support of more than $51 \%$ of the parliamentary members. It had thus crossed the minimum threshold for passing parliament and being submitted to Bundesrat (Federal Council) (Thurich, 2011). At Bundesrat, an assembly of representatives of the States' governments (comprised of: State- or Resort Ministers, Senators or Secretaries of State) agreed on the new law which became effective after signature of the Federal President in 2010. Political discourse, arguments and data used within that legislative process was a valuable source for analysing and identifying political objectives, information selection and interpretation. The parliamentary database provided all relevant official documents recording the process which allows us to comprehensively describe and analyse the parliamentary discourse.

\subsection{Method}

\subsubsection{The juridical approach}

The analysis of the research questions takes a juridical approach to study political objectives, information needs and interpretations. The reason for combing two strands of research, i.e. political- and legal studies, is their close relationship in real-world policy decisions. According to Slaughter (1995) law and politics "cohabit the same conceptual space" were they define objectives and rules that "seek to manipulate" the world (p. 503). In this definition, law is seen as a form of political control. It explains why law and politics are often studied in combination to better understand how both control society, economics and the natural environment (Mattli and Slaughter, 1995; Slaughter, 1995; Ribot, 1999). Based on the idea that political objectives are eventually put down into law, this study takes the documented legislative discourse as source of political objectives, conflict and data needs.

\subsubsection{Analysis of political motivations}

In analysis, I will devote a separate chapter to the individual legal sections each. Initially, chapters start with an introduction to the respective parliamentary discourse and an overview of political objectives and motivations for data use. The intention of identifying political 
objectives is to explain how they influenced the selection of information. I differentiate two different kinds:

(1) explicit objectives voiced openly during the parliamentary discourse and

(2) implicit, i.e. tacit objectives which are not openly voiced, but which become evident by decisions' practical consequences.

I studied these implicit consequences by juridical methods, i.e. I explained how politically favoured decisions affected other legal acts that regulate real-world problems. This analysis required an extensive review of the Federal Forest Act, its implications on other laws and the combined effect on real-world problems such as conservation obligations and the distribution of agricultural funds under the European Common Agricultural Policy (CAP).

These regulations may benefit certain groups of interest that lobby for political influence, such as the timber sector, or biodiversity conservation groups. Their interest and their implicit influence on policy decisions are most interesting from a political-research point of view because they may reveal true political motivations, whereas openly voiced objectives could merely be a political means of disguising the truth.

\subsubsection{Analysis of relevance}

In a second and more analytical step, I analysed political objectives regarding conflicts and I assessed the role of information when trying to solve those conflicts. That analysis is very interesting because it provides the unique opportunity to study the users' objectives and the role of political consent and dissent in data choice.

Analysis differentiated three components of data requirements:

1) attributes,

2) quality and

3) providers.

Using the documented discourse in- and outside plenary sessions, I quantified attributes by the number of different oral or written statements about forest facts and by the number of new attributes formally required under the definitions of the new law.

Quality requirements were the second criterion to be analysed. Yet, the parliamentary discourse did not reveal any evidence on technical quality standards as they are traditionally 
used by statisticians, such as spatial and temporary resolution or any other measurements of precision and accuracy. Quality needs were therefore identified by two methods: characteristics of measurement (such as sampling design) of quoted evidence and the level to which a given reference had been aggregated and condensed. Figure 4 illustrates the different levels. At the lowest, the quotations might be measured variables (tree height in meters), or at the higher levels, they might be results of analysis algorithms (volume growing stock by tree) or interpretations ("Germany has high timber resources"). Each quotation was categorised in either of these categories. The number of parliamentary decisions influenced by a certain category then measured the categories' relevance. Quantifying quality requirements in such way eventually helped to identify the level of data aggregation and presentation that was most relevant, understandable or trustworthy for policy-makers.

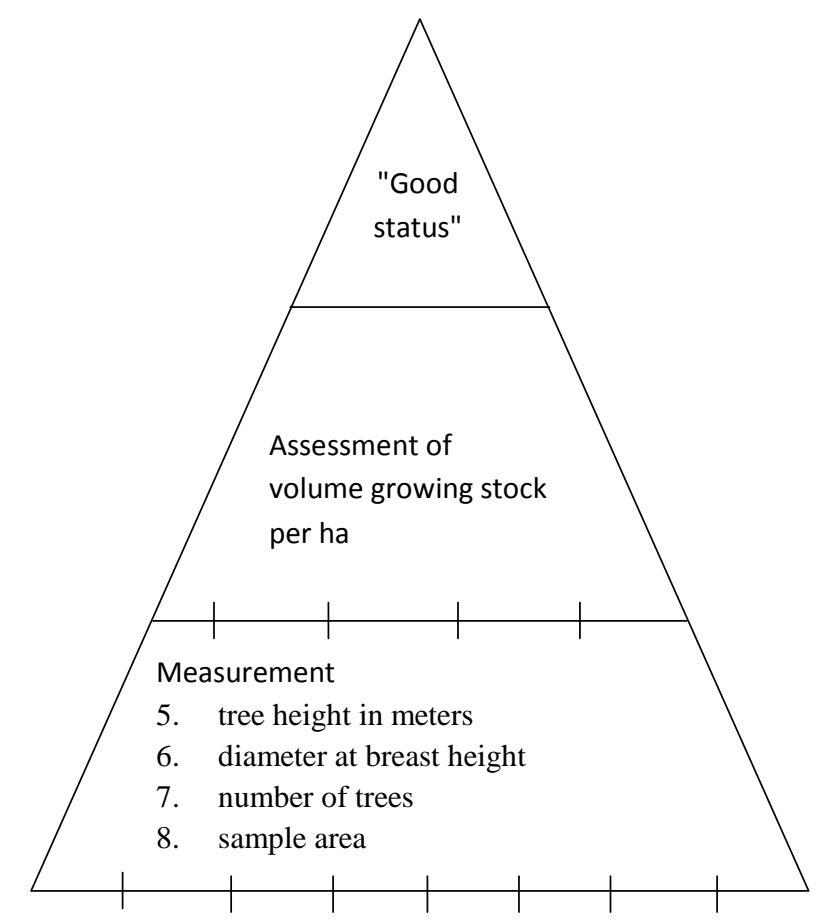

\section{Interpretation (qualitative)}

Policy performance by comparison against

some target value

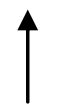

Analysis (quantitative)

Assessment algorithms

Measurements (quantitative)

Variables, plot- and sampling design

Figure 4. Levels of aggregating information.

Having analysed the first two components of data relevance, i.e. the required (1) attributes and (2) levels of data quality, analysis of the third component identified the most trusted providers, or so-called "epistemic actors" in the science-policy interface (cf. Haas, 1992). They were either evident from the quotations themselves or from other references elsewhere in the parliamentary report. Identifying providers was often a challenge, especially when parliamentarians did not directly refer to an inventory authority but to sources that allow only 
indirect inferences on background (field-) measurements. Reports for instance often compile, analyse and interpret information from various inventories and providers. In these cases, I retraced the chain of data generation back to its original sources: from the parliamentary statement, to the documented source, its different stages of analysis, and its original measurements. This method provided a comprehensive overview on all providers and authorities involved in the data generation process.

\subsubsection{Analysis of the risk of political bias}

While the outcomes on data relevance (research objective 1) relate to the side of data providers, analysis of the second research objective shall focus on the risk of political bias in political interpretations at the users-side. It bases on political theory presented in Chapters 1.2 and 1.3 which assumed that policy makers tacitly select information and bias interpretations in favour of political interests (Krott, 2012; Krott et al. 2014; Pregernig, 2007; Hertin et al., 2009; Haas, 2004; Pielke, 2007). As I have explained in Chapter 1.4.2, this theory shall be tested by confirming two conditions:

\section{1) Political motivations}

2) Non-transparent evidence, i.e. partial or absent evidence

The first component, political motivations were assessed in an introductory chapter to each topic of discourse. They follow the methodology presented above in section 3.3.2 and include (1) explicit objectives voiced openly during the parliamentary discourse and (2) implicit, i.e. tacit objectives which are not openly voiced, but which become evident by decisions' practical consequences. I quantified the second component, i.e. non-transparent evidence, by the number of unverified forest facts.

If these two conditions were confirmed, then the interpretation was assumed to be not verifiable and hidden believes or interests had a possible chance to influenced conclusions. Such findings are important because lack of verifiable evidence may undermine an equallyinformed discourse, where opponents may verify and challenge assumptions and thus join a democratic discourse on what would have been an optimal decision. 


\subsection{Results}

\subsubsection{Introduction to the amendment of BWaldG}

Before analysis of the political discourse, it is instrumental to introduce the object of discussion first. The following therefore presents the Federal Forest Act (BWaldG) and specifies changes on inventory-relevant sections. For that purpose I compared the different drafts, ranging from the original version, valid from 27.07.1984, to the first draft of an amendment proposed on 03.04.09 and and the final version enacted on 06.08.2010 (Table 7). Such temporal comparison was important because my analysis explained the political arguments made at each of the successive stages of the legal amendment. The following briefly describes the amended sections as illustrated in Table 7 and explains legal implications.

The first amendment is to be found in BWaldG, Section 2, Subsection 1 (§ 2(1)). It specified legally accepted criteria of the definition of forest areas. They included measureable components such as "coverage of forest plants", "clear-cut" or "thinned out areas", as well as examples of forest-related functions of areas connected to forests such as: "forest roads", "protective strip", "grasslands inside forests" and "browsing areas". These definitions remained unchanged, but the new version of $\S 2(2)$ added three land use classes that describe non-forest areas. These include:

1. Short rotation plantations: "areas with rotation period of up to 20 years",

2. Agroforestry: "areas with tree cover simultaneously serving cultivation of agricultural products",

3. Agriculture: Streamlining the definition of agricultural areas with the IACS database.

Another amendment in Section 3 (§ 3) redefined forest ownership. As before, it still differentiated 3 classes: The first class, "state forest" is under management regulations of federation and states. The other two classes, (2) "communal forest" (Körperschaftswald) and (3) "private forest", were not under state authority. Yet, the amendment in Subsection 2 removed forests under ownership of Anstalten des öffentlichen Rechts (public-law institutions) from the second category "communal forest" and shifted them to state authority. The legal implication was an extension of the influence of federation and states to additional forest areas. 
Section 11, BWaldG added criteria of "good practice" in forest management. The newly included Subsection 2 extended the existing requirements of afforestation and reforestation by obligations to "sufficiently" account for:

"1. forest functions as an archive of natural- and cultural history and

2. with regard to public parks, gardens and burial-grounds, the preservation of monuments."

The legal implication was that forest management remained largely unregulated, only if operations affected protected areas, protected species or their habitats then additional restrictions applied under various rules of BNatSchG.

Section 37 (2) and Section 40 (1), BWaldG defined responsibilities and economic rights of private forestry associations (Forstwirtschaftliche Vereinigungen) on the timber market. Sentence 4 of $\S 37$ (2) extended these rights towards "marketing and sales of the members' products", thus removing market constraints regarding cartel regulations of $\S 40$ (1).

Section 41a, BWaldG had the highest impact on forest inventory. It defined the mandate, the purpose and some principle targets of field measurements. As shown in Table 7, the amendment introduced as new elements:

(1) The requirement of data generation for legally-binding reporting obligations of the international community (UN-Habitats Directive, UNCBD, UNFCCC)

(2) A 10 year inventory cycle with mid-term carbon inventories

(3) The mandate to the federal ministry for forestry and agriculture (BMEL) for forest health- and forest soil inventories.

This amendment extended the mandate of NFI with the political intention to extend the knowledge-base as required for the implementation of international forest policy (e.g. WC Habitats Directive, UNCBD, UNFCCC, Kyoto Protocol). 
Table 7. The amendment of the Federal Forest Act (BWaldG) - original text

\begin{tabular}{|c|c|c|}
\hline $\begin{array}{l}\text { Ursprünglich } \\
\text { in der vom } 27.07 .1984 \text { bis zum } 06.08 .2010 \\
\text { geltenden Fassung } \\
\text { (BGBI. I S.1037 und 1037) }\end{array}$ & $\begin{array}{l}\text { 1. Entwurf vom } 03.04 .09 \\
(45 / 09 B)\end{array}$ & $\begin{array}{l}\text { 2. Entwurf (17/2184) vom } 16.06 .2010 \\
\text { und geändertes Gesetz in der ab dem } \\
06.08 .2010 \text { geltenden Fassung (BGBI. I S. } \\
\text { 1050) }\end{array}$ \\
\hline \multicolumn{3}{|l|}{$\S 2$ Wald } \\
\hline \multicolumn{3}{|c|}{$\begin{array}{l}\text { (1) Wald im Sinne dieses Gesetzes ist jede mit Forstpflanzen bestockte Grundfläche. Als Wald gelten auch kahlgeschlagene oder verlichtete } \\
\text { Grundflächen, Waldwege, Waldeinteilungs- und Sicherungsstreifen, Waldblößen und Lichtungen, Waldwiesen, Wildäsungsplätze, } \\
\text { Holzlagerplätze sowie weitere mit dem Wald verbundene und ihm dienende Flächen. }\end{array}$} \\
\hline \multicolumn{3}{|l|}{ (2) } \\
\hline & Kein Wald im Sinne dieses Gesetzes sind & Kein Wald im Sinne dieses Gesetzes sind_ \\
\hline & $\begin{array}{l}\text { 1. Flächen, die bei einer Umtriebszeit } \\
\text { von bis zu } 20 \text { Jahren mit } \\
\text { (Kurzumtriebsplantagen), }\end{array}$ & $\begin{array}{l}\text { 1. Grundflächen auf denen Baumarten mit } \\
\text { dem Ziel baldiger Holzentnahme } \\
\text { angepflanzt werden und deren Bestände } \\
\text { eine Umtriebszeit von nicht länger als } 20 \\
\text { Jahren haben (Kurzumtriebsplantagen), }\end{array}$ \\
\hline & $\begin{array}{l}\text { 2. Flächen mit Baumbestand, die } \\
\text { gleichzeitig dem Anbau } \\
\text { landwirtschaftlicher Produkte dienen } \\
\text { (agroforstliche Nutzung), und }\end{array}$ & $\begin{array}{l}\text { 2. Flächen mit Baumbestand, die gleichzeitig } \\
\text { dem Anbau landwirtschaftlicher Produkte } \\
\text { dienen (agroforstliche Nutzung), }\end{array}$ \\
\hline & & $\begin{array}{l}\text { 3. mit Forstpflanzen bestockte Flächen, die } \\
\text { am 6. August } 2010 \text { in dem in } \S 3 \text { Satz } \\
1 \text { der InVeKoS-Verordnung vom 3. } \\
\text { Dezember 2004 (BGBI. I S. 3194), die zuletzt } \\
\text { durch Artikel 2 der Verordnung vom 7. Mai } \\
2010 \text { (eBAnz AT51 2010 V1) geändert } \\
\text { worden ist, bezeichneten } \\
\text { Flächenidentifizierungssystem als } \\
\text { landwirtschaftliche Flächen erfasst sind, } \\
\text { solange deren landwirtschaftliche Nutzung } \\
\text { andauert und } \\
\end{array}$ \\
\hline $\begin{array}{l}\text { In der Flur oder im bebauten Gebiet gelegene } \\
\text { kleinere Flächen, die mit einzelnen } \\
\text { Baumgruppen, Baumreihen oder mit Hecken } \\
\text { bestockt sind oder als Baumschulen verwendet } \\
\text { werden,-sind nicht Wald im Sinne dieses } \\
\text { Gesetzes. }\end{array}$ & $\begin{array}{l}\text { 3. in der Flur oder im bebauten Gebiet } \\
\text { gelegene kleinere Flächen, die mit } \\
\text { einzelnen Baumgruppen, Baumreihen } \\
\text { oder mit Hecken bestockt sind oder als } \\
\text { Baumschulen verwendet werden. }\end{array}$ & $\begin{array}{l}\text { 4. in der Flur oder im bebauten Gebiet } \\
\text { gelegene kleinere Flächen, die mit einzelnen } \\
\text { Baumgruppen, Baumreihen oder mit } \\
\text { Hecken bestockt sind oder als Baumschulen } \\
\text { verwendet werden. }\end{array}$ \\
\hline \multicolumn{3}{|l|}{ § 3 Waldeigentumsarten } \\
\hline $\begin{array}{l}\text { (1) Staatswald im Sinne dieses Gesetzes ist } \\
\text { Wald, der im Alleineigentum des Bundes oder } \\
\text { eines Landes steht, sowie Wald im Miteigentum } \\
\text { eines Landes, soweit er nach landesrechtlichen } \\
\text { Vorschriften als Staatswald angesehen wird. }\end{array}$ & & $\begin{array}{l}\text { (1) Staatswald im Sinne dieses Gesetzes ist } \\
\text { Wald, der im Alleineigentum des Bundes, } \\
\text { eines Landes oder einer Anstalt oder } \\
\text { Stiftung des öffentlichen Rechts steht, sowie } \\
\text { Wald im Miteigentum eines Landes, soweit } \\
\text { er nach landesrechtlichen Vorschriften als } \\
\text { Staatswald angesehen wird. }\end{array}$ \\
\hline $\begin{array}{l}\text { (2) Körperschaftswald im Sinne dieses Gesetzes } \\
\text { ist Wald, der im Alleineigentum der } \\
\text { Gemeinden, der Gemeindeverbände, der } \\
\text { Zweckverbände sowie sonstiger } \\
\text { Körperschaften, Anstalten und Stiftungen des } \\
\text { öffentlichen Rechts steht; ausgenommen ist der } \\
\text { Wald von Religionsgemeinschaften und deren } \\
\text { Einrichtungen, sowie von Realverbänden, } \\
\text { Hauberggenossenschaften, } \\
\text { Markgenossenschaften, Gehöferschaften und } \\
\text { ähnlichen Gemeinschaften } \\
\text { (Gemeinschaftsforsten), soweit er nicht nach } \\
\text { landesrechtlichen Vorschriften als } \\
\text { Körperschaftswald angesehen wird. }\end{array}$ & & $\begin{array}{l}\text { (2) Körperschaftswald im Sinne dieses } \\
\text { Gesetzes ist Wald, der im Alleineigentum } \\
\text { der Gemeinden, der Gemeindeverbände, } \\
\text { der Zweckverbände sowie sonstiger } \\
\text { Körperschaften des öffentlichen Rechts } \\
\text { steht; ausgenommen ist der Wald von } \\
\text { Religionsgemeinschaften und deren } \\
\text { Einrichtungen, sowie von Realverbänden, } \\
\text { Hauberggenossenschaften, } \\
\text { Markgenossenschaften, Gehöferschaften } \\
\text { und ähnlichen Gemeinschaften } \\
\text { (Gemeinschaftsforsten), soweit er nicht } \\
\text { nach landesrechtlichen Vorschriften als } \\
\text { Körperschaftswald angesehen wird. }\end{array}$ \\
\hline \multicolumn{3}{|c|}{ 3) Privatwald im Sinne dieses Gesetzes ist Wald, der weder Staatswald noch Körperschaftswald ist. } \\
\hline \multicolumn{3}{|l|}{$\S 37$ Begriffe und Aufgabe } \\
\hline \multicolumn{3}{|c|}{$\begin{array}{l}\text { (1) Forstwirtschaftliche Vereinigungen sind privatrechtliche Zusammenschlüsse von anerkannten Forstbetriebsgemeinschaften, } \\
\text { Forstbetriebsverbänden oder nach Landesrecht gebildeten Waldwirtschaftsgenossenschaften oder ähnlichen Zusammenschlüssen } \\
\text { einschließlich der Gemeinschaftsforsten zu dem ausschließlichen Zweck, auf die Anpassung der forstwirtschaftlichen Erzeugung und des } \\
\text { Absatzes von Forsterzeugnissen an die Erfordernisse des Marktes hinzuwirken. }\end{array}$} \\
\hline
\end{tabular}


1. Unterrichtung und Beratung der Mitglieder sowie Beteiligung an der forstlichen Rahmenplanung;

2. Koordinierung des Absatzes;

3. marktgerechte Aufbereitung und Lagerung der Erzeugnisse;

\begin{tabular}{|l|l|l|}
\hline & & $\underline{4 . \text { Vermarktung der Erzeugnisse der }}$ \\
\hline $\begin{array}{l}\text { 4. Beschaffung und Einsatz von Maschinen und } \\
\text { Geräten }\end{array}$ & & $\begin{array}{l}\text { 5. Beschaffung und Einsatz von Maschinen } \\
\text { und Geräten }\end{array}$ \\
\hline
\end{tabular}

\section{§ 40 Befreiung von Vorschriften des Gesetzes gegen Wettbewerbsbeschränkungen}

(1) $§ 1$ des Gesetzes gegen

Wettbewerbsbeschränkungen findet keine

Anwendung auf Beschlüsse von Vereinigungen

forstwirtschaftlicher Erzeugerbetriebe, von

anerkannten Forstbetriebsgemeinschaften und

von Forstbetriebsverbänden, soweit sie die

forstwirtschaftliche Erzeugung und den Absatz

von Forsterzeugnissen betreffen. Das gleiche

gilt für die nach Landesrecht gebildeten

öffentlich-rechtlichen

Waldwirtschaftsgenossenschaften und ähnliche

Zusammenschlüsse in der Forstwirtschaft,

sofern sie einen wesentlichen Wettbewerb auf

dem Holzmarkt bestehen lassen.
(1) § 1 des Gesetzes gegen

Wettbewerbsbeschränkungen findet keine

Anwendung auf Beschlüsse von

Vereinigungen forstwirtschaftlicher

Erzeugerbetriebe, von anerkannten

Forstbetriebsgemeinschaften, von

Forstbetriebsverbänden und von

forstwirtschaftlichen Vereinigungen, soweit

sie die forstwirtschaftliche Erzeugung und

den Absatz von Forsterzeugnissen

betreffen. Das gleiche gilt für die nach

Landesrecht gebildeten öffentlich-

rechtlichen

Waldwirtschaftsgenossenschaften und

ähnliche Zusammenschlüsse in der

Forstwirtschaft, sofern sie einen

wesentlichen Wettbewerb auf dem

Holzmarkt bestehen lassen.

(2) Eine anerkannte Forstwirtschaftliche Vereinigung im Sinne dieses Gesetzes darf ihre Mitglieder bei der Preisbildung beraten und zu diesem Zweck gegenüber ihren Mitgliedern Preisempfehlungen aussprechen.

(3) Im Übrigen bleiben die Vorschriften des Gesetzes gegen Wettbewerbsbeschränkungen unberührt.

(4) Als Vereinigungen forstwirtschaftlicher Erzeugerbetriebe sind Waldwirtschaftsgemeinschaften, Waldwirtschaftsgenossenschaften, Forstverbände, Eigentumsgenossenschaften und ähnliche Vereinigungen anzusehen, deren Wirkungskreis nicht wesentlich über das Gebiet einer Gemarkung oder einer Gemeinde hinausgeht und die zur gemeinschaftlichen Durchführung forstbetrieblicher Maßnahmen gebildet werden oder gebildet worden sind.

\section{§ 11 Bewirtschaftung des Waldes}

(1) Der Wald soll im Rahmen seiner Zweckbestimmung ordnungsgemäß und nachhaltig bewirtschaftet werden. Durch Landesgesetz ist mindestens die Verpflichtung für alle Waldbesitzer zu regeln, kahlgeschlagene Waldflächen oder verlichtete Waldbestände in angemessener Frist

1. wieder aufzuforsten oder

2. zu ergänzen, soweit die natürliche Wiederbestockung unvollständig bleibt,

falls nicht die Umwandlung in eine andere Nutzungsart genehmigt worden oder sonst zulässig ist.

\begin{tabular}{|c|c|}
\hline & $\begin{array}{l}\text { 2) Bei der Bewirtschaftung sollen } \\
\text { 1. die Funktion des Waldes als Archiv der } \\
\text { Natur- und Kulturgeschichte sowie } \\
\text { 2. im Falle von Parkanlagen, Gartenanlagen } \\
\text { und Friedhofsanlagen die } \\
\text { denkmalpflegerischen Belange } \\
\text { angemessen berücksichtigt werden. }\end{array}$ \\
\hline § 41 a Bundeswaldinventur & § 41 a Walderhebungen \\
\hline $\begin{array}{l}\text { (1) Zur Erfüllung der Aufgaben dieses Gesetzes } \\
\text { ist eine auf das gesamte Bundesgebiet } \\
\text { bezogene forstliche Großrauminventur auf } \\
\text { Stichprobenbasis (Bundeswaldinventur) } \\
\text { durchzuführen. Sie soll einen Gesamtüberblick } \\
\text { über die großräumigen Waldverhältnisse und } \\
\text { forstlichen Produktionsmöglichkeiten liefern. } \\
\text { Die hierzu erforderlichen Messungen und } \\
\text { Beschreibungen des Waldzustandes } \\
\text { (Grunddaten) sind nach einem einheitlichen } \\
\text { Verfahren vorzunehmen. Bei Bedarf ist die } \\
\text { Inventurzuwiederholen. }\end{array}$ & $\begin{array}{l}\text { (1) Zur Erfüllung der Aufgaben dieses } \\
\text { Gesetzes sowie zur Durchführung von } \\
\text { Rechtsakten der Europäischen Union oder } \\
\text { völkerrechtlich verbindlicher Vereinbarungen } \\
\text { im Anwendungsbereich dieses Gesetzes ist } \\
\text { vorbehaltlich des Absatzes } 3 \text { alle zehn Jahre } \\
\text { eine auf das gesamte Bundesgebiet bezogene } \\
\text { forstliche Großrauminventur auf } \\
\text { Stichprobenbasis (Bundeswaldinventur) } \\
\text { durchzuführen. Sie soll einen } \\
\text { Gesamtüberblick über die großräumigen } \\
\text { Waldverhältnisse und forstlichen } \\
\text { Produktionsmöglichkeiten liefern. Die hierzu } \\
\text { erforderlichen Messungen und } \\
\text { Beschreibungen des Waldzustandes } \\
\text { (Grunddaten) sind nach einem einheitlichen } \\
\text { Verfahren vorzunehmen. Dabei ist auf die } \\
\text { Verwertbarkeit der Grunddaten auch im }\end{array}$ \\
\hline
\end{tabular}




\begin{tabular}{|c|c|}
\hline & $\begin{array}{l}\text { Rahmen der Beobachtung nach } \S 6 \\
\text { Bundesnaturschutzgesetz zu achten. }\end{array}$ \\
\hline \multicolumn{2}{|c|}{$\begin{array}{l}\text { (2) Die Länder erheben die in Absatz } 1 \text { genannten Grunddaten; das Bundesministerium für Ernährung, Landwirtschaft und } \\
\text { Verbraucherschutz stellt sie zusammen und wertet sie aus. }\end{array}$} \\
\hline & $\begin{array}{l}\text { (3) Zur Erfüllung von Berichtspflichten, die auf } \\
\text { Grund verbindlicher völkerrechtlicher } \\
\text { Vereinbarungen zum Schutz des Klimas } \\
\text { bestehen, erhebt das Bundesministerium für } \\
\text { Ernährung, Landwirtschaft und } \\
\text { Verbraucherschutz soweit erforderlich in den } \\
\text { Jahren zwischen zwei Bundeswaldinventuren } \\
\text { Daten zum Kohlenstoffvorrat im Wald. }\end{array}$ \\
\hline $\begin{array}{l}\text { (3) Die mit der Vorbereitung und Durchführung } \\
\text { der Bundeswaldinventurbeauftragten } \\
\text { Personen sind berechtigt, zur Erfüllung ihres } \\
\text { Auftrages Grundstücke zu betreten sowie die } \\
\text { erforderlichen nvarbeiten auf diesen } \\
\text { Grundstücken durchzuführen. }\end{array}$ & $\begin{array}{l}\text { (4) Die mit der Vorbereitung und } \\
\text { Durchführung der in den Absätzen 1,3 und in } \\
\text { Rechtsverordnungen nach Absatz } 6 \\
\text { genannten forstlichen Erhebungen } \\
\text { beauftragten Personen sind berechtigt, zur } \\
\text { Erfüllung ihres Auftrages Grundstücke zu } \\
\text { betreten sowie die erforderlichen } \\
\text { Datenerhebungen und Probenahmen auf } \\
\text { diesen Grundstücken durchzuführen. }\end{array}$ \\
\hline \multirow[t]{2}{*}{$\begin{array}{l}\text { (4) Das Bundesministerium für Ernährung, } \\
\text { Landwirtschaft und Verbraucherschutz wird } \\
\text { ermächtigt, durch Rechtsverordnung mit } \\
\text { Zustimmung des Bundesrates den Zeitpunkt der } \\
\text { Bundeswaldinventur zu bestimmen sowie } \\
\text { nähere Vorschriften über das Aath Abstz } 1 \\
\text { anzuwendende Stichprobenverfahren und die } \\
\text { zu ermittelnden Grunddaten zu erlassen. }\end{array}$} & $\begin{array}{l}\text { (5) Das Bundesministerium für Ernährung, } \\
\text { Landwirtschaft und Verbraucherschutz wird } \\
\text { ermächtigt, durch Rechtsverordnung mit } \\
\text { Zustimmung des Bundesrates nähere } \\
\text { Vorschriften über das für die } \\
\text { Bundeswaldinventur anzuwendende } \\
\text { Stichprobenverfahren und die zu } \\
\text { ermittelnden Grunddaten zu erlassen. }\end{array}$ \\
\hline & 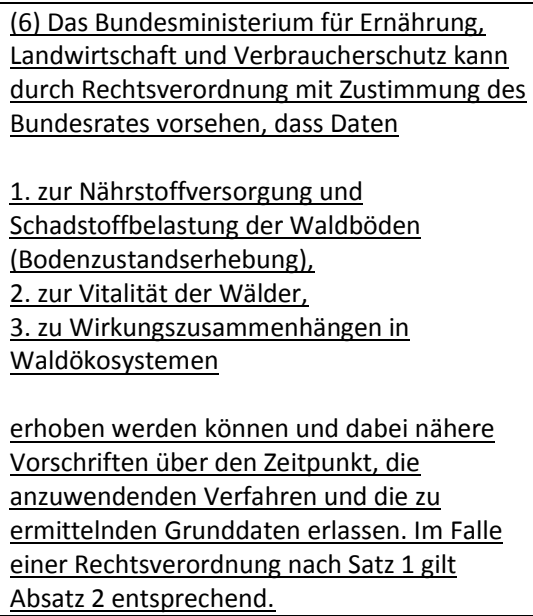 \\
\hline
\end{tabular}




\subsubsection{Short rotation plantations - BWaldG $\S 2$}

\subsubsection{Overview of discourse history and political motivations}

The first of the described amendments to be analysed in this section is the definition of short rotation plantations in $\S 2$, BWaldG. As announced, I introduce my analysis by a chronological overview of the discourse history. I will point-out explicit, i.e. openly voiced objectives, and implicit ones, i.e. objectives which become evident from legal consequences of a preferred decision (cf. Ch. 3.3.2). Such kind of evidence will help to better understand the political backgrounds and to answer the two research questions: (Q1) the perceived relevance of information when solving political conflicts and (Q2) the risk of political bias.

In 24.03.2010, by amendment of $\S 2$, the Bundesrat decided to bring the exclusion of "short rotation plantations" into parliamentary discussion. It supported the decision by a conflict of short-rotation plantations with other legal regulations of "sustainable forest management" (p.m. 45/09 B p.3). One of such legal regulation is certainly the protection of biodiversity as one important component of discussions on sustainable forest management. In this opinion, specifically Greens and SPD followed recommendations of a nature conservation organisation, the NABU. In 2004, a NABU consultant recommended the exclusion of short rotation plantations from the legal "forest area" definition because short rotation plantations were expected to provide higher biodiversity gains compared to other, more intensive agricultural management practices (cf. Heinrich, 2004, p.7). Even though the quoted referee admitted that there was no reliable information on biodiversity effects (Box 7), Greens and SPD took them for granted and thus supported short-rotation plantations in spite of partially absent information.

The motivation was to subject the establishment of short-rotation plantations on forest areas under the same legal and administrative restrictions as those already applied for deforestation measures. This means that under the new law, the establishment of short-rotation plantations on forested areas was legally defined as deforestation and it was therefore an "intervention in nature and landscape" under the rules of $\S 14$ and $\S 15$ Federal Nature Conservation Act (BNatSchG). The rules demand so-called "compensation" measures (Ausgleichsmaßnahmen). A possible example is afforestation nearby a deforested site. If such "compensation" measures are not feasible, a second option is "substitution" (Ersatz). It substitutes loss of ecosystem values by enhancement of existing values and functions. An example could be restoring 
wetland functions in substitution to loss of water storage within a deforested site. A third option is "substitution payment". All three alternatives either required purchase of land or different forms of expenses for compensation measures. In any case, they result in a monetary burden to the intervening actors. The new law thus deterred investors from the establishment of short rotation plantations inside forest. This may have been a desired effect and political motivation of the Greens and SPD.

Similar as these parties, the governing centre-right coalition agreed to the exclusion of "short rotation plantations", but their primary motivation was different. Rather than discouraging investors from establishing new plantations, they wanted to de-regulate forest management on short rotation plantations and strengthen timber extraction by removing plantations from the protection of forest law: Previously, $\S 11 \mathrm{BWaldG}$ protected forests by the requirement of managing forest "properly and sustainably". The specification of that requirement by obligatory management regulations of "good practice" was under discussion at the same time. From the coalition's perspective, the problem was that the management standards would have further restricted the exploitation of forests. The centre-right parties hence demanded the exclusion of plantations from these rules, thus strengthening the timber sector, specifically in the alpine regions of Bavaria were the new law removed privately owned forested mountain pastures from the protection of the forest act (Christel Happach-Kasan-FDP, plenary protocol 17/49, cf. Box 5). The argument was that "traditional" agro-forestry regimes were seen as an important resource for timber extraction. Forest information played an important role at this stage. Since the previous legislative period, the liberals of FDP supported such arguments by NFI results (cf. Box 6). 
"The exclusion of sparsely forested mountain pastures in the alpine region follows on Bavarian request. In order to ensure the traditional management regime, we have found a reasonable solution that aims at persistent agricultural use of the relevant areas. In case of abandoning agricultural use and increasingly dense stands, the areas would convert to forest. The implementation of the Alpine Convention is enforced by that clarification. Protection forests are no agriculturally used areas and therefore, they are not affected by this regulation" (translated by the author)

"Die Herausnahme der licht bewaldeten Bergalmen im Alpenraum erfolgte auf bayrischen Wunsch. Um die traditionelle Bewirtschaftungsform zu gewährleisten, haben wir einen vernünftigen Weg gefunden, der sich an einer fortdauernden landwirtschaftlichen Nutzung der betroffenen Flächen orientiert. Bei Aufgabe der landwirtschaftlichen Nutzung und zunehmender Bestockung werden diese Almen zu Wald. Die Umsetzung der Alpenkonvention wird durch diese Klarstellung gestärkt. Schutzwälder sind keine landwirtschaftlich genutzten Flächen und daher von der Regelung nicht betroffen." (original text in German)

Source: Christel Happach-Kasan (FDP), 17.06.2010. Plenary protocol 17/49, p. 5162

Box 5. FDP - support of the timber market

"According to results of the national forest inventory, Germany uses only about $60 \%$ of yearly wood increments. Especially private forests have accumulated large stocks of $354 \mathrm{~m}^{3} / \mathrm{h}$. One reason is relatively high costs for the provision of wood products, when compared to sales revenues. $A$ successful implementation of the national Timber Charta must mobilize these potentials" (translated by the author)

"Nach den Ergebnissen der Bundeswaldinventur wird in Deutschland nur ein Anteil von etwa 60 Prozent des in jedem Jahr nachwachsenden Holzes genutzt. Insbesondere im Kleinprivatwald sind in den letzten Jahren mit $354 \mathrm{~m}^{3}$ pro Hektar sehr hohe Hektarvorräte aufgebaut worden. Eine Ursache dafür sind die im Vergleich zu den erzielten Verkaufserlösen beim Industrie- und Stammholz hohen Kosten für die Bereitstellung von Holz. Eine erfolgreiche Umsetzung der Charta für Holz muss diese Potenziale mobilisieren." (original text in German)

Source: Dr. Christel Happach-Kasan (FDP), Hans-Michael Goldmann (FDP), Dr. Karl Addicks (FDP), other Members of Parliament and the FDP Group, 17.07.2006. Governmental reply to a letter of enquiry: p.m. 16/2235, p. 1 )

Box 6. FDP - support of timber extraction in private forests

The coalition also emphasized "increasing demand of wood for renewable energies" (Alois Gering CDU/CSU, p.m. 17/49), thus interpreting results from the "Cluster-study Forest and Wood". However, the quoted study specifically highlighted the fact that available data did not allow any reliable national-level estimates on the sector of renewable energies (Mrosek et al., 2005, p.6). By making conclusions in spite of incomplete information, the parliamentary statement misinterpreted the study's information. 
Based on the consultation of a NABU expert, the coalition partners further assumed that short-rotation plantations provided ecological benefits because "species diversity is significantly higher" than in corn-plantations (Christel Happach-Kasan, plenary protocols: $17 / 49$, p. $5162 ; 17 / 43$ p. 4327). This statement refers to a study presented by a NABU consultant (Box 7). In that study, Bielefeldt et al. (2008) compared biodiversity effects in agricultural areas with those in short rotation plantations. However, the consulted source did not provide nation-wide estimates of areas affected by positive biodiversity affects on short rotation plantations and on (other) agriculturally managed areas. Eventually, assumptions on national biodiversity effects, as made in parliament, were not plausible to the opposition: the Greens denied a causal relationship claiming that "short rotation plantations [were] nothing else than monocultures of forest species on cropland." (Cornelia Behm, plenary protocol: 17/43, p. 4329).

"From a biodiversity perspective, short rotation might represent enrichment in poorly forested, barren landscapes with predominately arable farming. Here the establishment of SRP [note by the author: Short Rotation Plantation] contributes to a structuring the landscape and creates habitats and stepping-stones for plant species. In SRP the diversity of plants is, however, smaller than in nearnatural forests. For the purpose of comparisons to grassland use reliable background-research is missing so far, especially on poplar plantations." (translated by the author)

"Kurzumtriebsplantagen können aus Sicht der Biodiversität eine Bereicherung in waldarmen, ausgeräumten Landschaften mit überwiegend ackerbaulicher Nutzung darstellen. Hier trägt die Anlage von KUP zu einer Strukturierung der Landschaft bei und schafft Lebensräume und Trittsteine für Pflanzenarten. Die Pflanzendiversität in KUP verglichen mit naturnahen Wäldern ist jedoch geringer. Für einen Vergleich zur Grünlandnutzung fehlen bisher noch belastbare Grundlagenuntersuchungen in Deutschland, insbesondere in Pappelplantagen." (original text in German)

Source: Bielefeldt, J; Bolte, A; Busch, G; Dohrenbusch, A; Kroiher, F; Lamersdorf, N; Schulz, U; Stoll, B (2008) p.14

Box 7. NABU study giving policy advice

\subsubsection{Relevance $(Q 1)$ and the risk of political bias $(Q 2)$}

Relevant to the discourse on short rotation plantations was information from the ministry's forest report (BMEL, 2009), its cluster study on the forestry sector, and a NABU-funded casestudy. The respectively consulted attributes and providers are shown in Table 8. These types of sources were further different in terms of quality: Ministry information on forest area and growing stock based on national-level NFI estimates. These figures remained undisputed in 
parliament. However, the NABU-information interpreted biodiversity effects using only case study-data without such national level estimates. The same applied to the cluster-studies' assumptions on future demands of the renewable energies sector. These interpretations were disputed. That observation is very important from the perspective of forest inventory because it provides evidence on quality requirements. Though statistical values of precision and accuracy were never quoted in the parliamentary process, the acceptance of NFI-based knowledge indicates that national-level estimates made political arguments more powerful than arguments quoting case-studies.

The basic problem of the discursive conflict was that none of the consulted studies was in position to provide national-level area estimates on the subject of discussion: the "short rotation plantations". The lack of verifiable national-level area estimates eventually resulted in different interpretations, depending on the politically favoured argument. Political motivations thus influenced, i.e. biased interpretations towards a preferred conclusion, while at the same time, the lack of evidence did not allow verification of respective claims. We may assume that availability of area estimates of short rotation plantations would had contributed towards a more objective discourse.

In response to these requirements, in 2012, the third NFI did not fully harmonise its forest definition with the legal one. Thus, it still includes short-rotation-plantations under its definition of forest areas (BMELV, 2014). Yet, a separate variable on short rotation plantations allows estimation of such areas and distinguishes them from areas under forestry use (BMELV, 2014). Based on such data, it would thus become possible to derive separated figures for the individual management effects on such areas, especially regarding two important political targets that framed discussions on SFM and its criteria on "good practice in forest management", namely: biodiversity and (wood) resource provision. 
Table 8. $\S 2$ "Short rotation plantations" - Information relevance and transparency of interpretations. (The table presents political parties that contributed to the parliamentary discourse. Politically "relevant" information is quantified by the sources consulted in parliament. "Non-transparent" information is characterised by parliamentary statements without supporting evidence.)

\begin{tabular}{|c|c|c|c|c|c|c|}
\hline & \multicolumn{4}{|l|}{ Q 1 Relevance } & \multicolumn{2}{|c|}{$\begin{array}{l}\text { Q } 2 \text { Risk of political bias } \\
\text { (confirmed under } 2 \text { conditions) }\end{array}$} \\
\hline \multirow[t]{3}{*}{ Political parties } & \multirow{3}{*}{$\begin{array}{l}\text { Attribute } \\
\text { (by statement or argument about } \\
\text { forest facts) }\end{array}$} & \multicolumn{3}{|c|}{ Provider $^{1}$ and Quality ${ }^{2}$} & Lack of & Political motivation \\
\hline & & $\begin{array}{l}\text { NFI } 2002 \\
\text { (with } \\
\text { spatial } \\
\text { estimates) }\end{array}$ & $\begin{array}{l}\text { Case studies } \\
\text { (without } \\
\text { spatial } \\
\text { estimates) }\end{array}$ & $\begin{array}{l}\text { No } \\
\text { data }\end{array}$ & $\begin{array}{l}\text { Assumption without } \\
\text { evidence }\end{array}$ & $\begin{array}{l}\text { Evident from } \\
\text { discourse ( explicit) } \\
\text { or consequences } \\
\text { (implicit) }\end{array}$ \\
\hline & & TI, BMEL & NABU & & & \\
\hline $\begin{array}{l}\text { SPD, Greens and } \\
\text { Linke }\end{array}$ & $\begin{array}{l}\text { Area short rotation plantation } \\
\text { (ha) } \\
\text { "Biodiversity" indicators }\end{array}$ & & $\mathrm{x}$ & $x$ & $x$ & $\begin{array}{l}\text { Deter establishment } \\
\text { of short rotation } \\
\text { plantations }\end{array}$ \\
\hline CDU/CSU, FDP & $\begin{array}{l}\text { Area short rotation plantation } \\
\text { (ha) } \\
\text { "Biodiversity" indicators } \\
\text { Exploitation of growing stock } \\
\left(\mathrm{m}^{3} / \mathrm{ha}\right) \\
\text { Yearly increment of growing } \\
\text { stocks }\left(\mathrm{m}^{3} / \mathrm{yr}\right)\end{array}$ & $x$ & $\mathrm{x}$ & $x$ & $x$ & $\begin{array}{l}\text { De-regulate forestry } \\
\text { on short rotation } \\
\text { plantations }\end{array}$ \\
\hline
\end{tabular}

BMEL Bundesministerium für Ernährung und Landwirtschaft (Federal Ministry for Food and Agriculture)

NABU Nature And Biodiversity Conservation Union (Non-Governmental Organisation)

NFI National Forest Inventory

TI Thünen Institute (Federal Research Institute for Rural Areas, Forestry and Fisheries)

$1 \quad$ Provider is the provisioning authority

2 Data quality is indicated by the assessment methods: "National Inventory" and "Case Study".

\subsubsection{Agroforestry - BWaldG $\S 2$}

\subsubsection{Overview of discourse history and political motivations}

Another parliamentary decision that is important to the present study was the exclusion of areas under agroforestry-use from the definition of forest areas in $\S 2$ sentence 2 BWaldG. As above, I will again introduce the discourse and study the political background objectives using the parliamentary argumentations and practical implications of the legal amendment.

The political discourse started with the submission of the draft act of the Bundesrat on 24.03.2010 (p.m. 17/1220). CDU/CSU and FDP supported the idea by economic arguments similar to those used for short rotation plantations: They wanted exclusion to allow continued use of agroforestry systems, particularly in the interests of Bavarian mountain pasture farmers. That type of management was under threat by another topic under discussion: the 
"good practice criteria" of sustainable forest management. If these were to be implemented successfully, and if mountain pasture-management stayed within the forest definition, then areas with sufficient tree cover would have been regulated by a tight set of management rules, thus limiting maximum allowable wood-extractions. The coalition wanted agroforestry areas to be exempted from these rules.

The Greens and SPD however denied their consent after a meeting of the agriculture-board. They believed that a certain form of agroforestry, "forested mountain pasture", largely qualifies for a specific protection status: "Schutzwald" ("protection forest") (Petra Crone, SPD, in: plenary protocol 17/49). These areas should remain under forest definition, because forest status was the basic requirement for the following protection regulations under federal and state laws:

That regulation says that on legally designated "Schutzwald" areas, management needs to adhere to more restrictions than management on other forest land. In Bavaria for instance, the establishment of the following management infrastructures requires special governmental consent: landings (Holzlagerplätze), forest tracks (Waldwege), firebreaks and forest aisles (Waldeinteilungs- und Sicherungsstreifen), temporarily unstocked lands and clearings, (Waldblößen), feeding grounds for game and forest glades (Waldwiesen und Lichtungen) (cf. Article 9 BayWaldG, 2005). The general purpose of protecting forests from these infrastructures was to limit timber harvests and to maintain ecosystem functions of forests such as erosion- and flooding-control, as well as wind protection. Under legal regulation, all forest-areas providing such functions had a potential of being protected under Schutzwaldstatus.

Greens and SPD wanted to maintain such legal protection of specific areas: The protection of areas with wooded pastures, i.e. wooded areas with agroforestry-use, by a legal Schutzwaldstatus should avoid intensification of timber extraction. They assumed that without such protection, the areas would be gradually thinned out, and soon disqualify for forest status. The governing coalition however believed in the opposite when they claimed that Schutzwald areas will not be deforested under the new law because they were assumed to be "not agriculturally managed" (Happach-Kasan, FDP, in: Plenary Protocol 17/49) and the party believed the areas did not overlap with "mountain pastures". 


\subsubsection{Relevance $(Q 1)$ and the risk of political bias $(Q 2)$}

The conflict in the above discourse on agroforestry in Schutzwald areas lay within the different political motivations and the respective definitions of Schutzwald, where each definition may lead to purposeful data-choice and interpretations (Table 9): The opposition defined Schutzwald as areas providing protective functions. These areas may include open spaces with sparse canopy cover and agroforestry-use, such as forest pastures, that do not necessarily qualify as forest under NFI. But the coalition defined Schutzwald by legal designation status. According to Bavarian state-law (Article 9 and 10, BayWaldG) these may cover only areas defined as forest under NFI. Thus depending on the chosen definition, parties assumed different effects of agroforestry management on NFI forest cover estimates: the opposition assumed forest cover loss, while the governing coalition believed there would be no changes.

Eventually, no party was in the position to provide background data supporting individual claims on the spatial extent and overlap of areas with (1) Schutzwald-designation (2) pastoral management practices, (3) forest status and (4) provision of protective functions. The document under consultation, the BMEL forest report (2009), did not provide such figures. The lack of evidence eventually allowed conclusions that were biased towards the political motivations: The opposition claimed there would be deforestation, a conclusion that supported the motivation of protection, while the governing coalition believed there would be no deforestation, a conclusion that supported the political motivation of not protecting the areas and continuing agroforestry-use. Yet no party was in the position to verify respective claims (Table 9). We may conclude that interpretations were politically biased and availability of up-to-date and precise NFI estimates would have brought the discourse to a more objective and evidence-based level.

In 2012, the third NFI responded to these requirements and included areas designated as protective forests as an additional variable which now allows assessment of (2) forest coverage on these areas. Yet, it still does not measure pastoral management practices (forest cover $\leq 50 \%$ ) and (4) provision of protective-functions. 
Table 9. § 2 "Agroforestry" - Information relevance and transparency of interpretations. (The table presents political parties that contributed to the parliamentary discourse. Politically "relevant" information is characterised by the sources consulted in parliament. "Nontransparent" information is characterized by parliamentary statements without supporting evidence.)

\begin{tabular}{|c|c|c|c|c|c|}
\hline \multirow{3}{*}{$\begin{array}{l}\text { Political } \\
\text { parties }\end{array}$} & \multicolumn{3}{|l|}{ Q1 Relevance } & \multicolumn{2}{|c|}{$\begin{array}{l}\text { Q } 2 \text { Risk of political bias } \\
\text { (confirmed under } 2 \text { conditions) }\end{array}$} \\
\hline & \multirow{2}{*}{$\begin{array}{l}\text { Attribute } \\
\text { (by statement or argument about forest } \\
\text { facts) }\end{array}$} & \multicolumn{2}{|c|}{ Provider $^{1}$ and Quality ${ }^{2}$} & \multirow{2}{*}{$\begin{array}{l}\text { Lack of transparency } \\
\text { Assumption without } \\
\text { evidence }\end{array}$} & \multirow{2}{*}{$\begin{array}{l}\text { Political motivation } \\
\text { Evident from discourse } \\
\text { (explicit or implicit) }\end{array}$} \\
\hline & & $\begin{array}{l}\text { NFI } 2002 \\
\text { (with } \\
\text { spatial } \\
\text { estimates) } \\
\text { Tl BMEL }\end{array}$ & No data & & \\
\hline $\begin{array}{l}\text { SPD, Greens, } \\
\text { Linke }\end{array}$ & $\begin{array}{l}\text { Forest area change (ha) } \\
\text { "Protective forest" = Areas with } \\
\text { protective functions (ha) } \\
\text { Areas with mountain pasture } \\
\text { management (ha) }\end{array}$ & $x$ & $\begin{array}{l}x \\
x\end{array}$ & $\begin{array}{l}x \\
x\end{array}$ & $\begin{array}{l}\text { Keep forested mountain } \\
\text { pastures with "protective } \\
\text { functions" under } \\
\text { regulation of BWaldG }\end{array}$ \\
\hline CDU/CSU, FDP & $\begin{array}{l}\text { Forest area change (ha) } \\
\text { Exploitation of growing stock }\left(\mathrm{m}^{3} / \mathrm{ha}\right) \\
\text { "Protective forest" = Areas designated as } \\
\text { protective forest (ha) } \\
\text { Pastoral management practices (forest } \\
\text { cover } \leq 50 \% \text { ) (ha) }\end{array}$ & $\begin{array}{ll}\mathrm{x} \\
\mathrm{x}\end{array}$ & $x$ & $x$ & $\begin{array}{l}\text { De-regulate agroforestry } \\
\text { on mountain pastures }\end{array}$ \\
\hline
\end{tabular}

BMEL Bundesministerium für Ernährung und Landwirtschaft (Federal Ministry for Food and Agriculture)

NFI National Forest Inventory

TI Thünen Institute (Federal Research Institute for Rural Areas, Forestry and Fisheries)

$1 \quad$ Provider is the provisioning authority

2 Data quality is indicated by the assessment methods and the availability of statistical area estimates.

\subsubsection{Harmonisation with European IACS database - BWaldG $\S 2$}

\subsubsection{Overview of discourse history and political objectives}

The parliament did not only discuss the exclusion of agroforestry from the forest area definition. It also harmonised the legal delineation of agricultural and forest areas with the "Integrated Administration and Control System database" (IACS database).

To better understand the political backgrounds, I will again introduce by analysis of political motivations. Yet, this time, in contrast to previously analysed discourses, there was neither conflict nor argument in parliament. For this reason I point-out only implicit objectives, i.e. objectives that do not become evident from the discourse but from practical consequences. To understand these consequences a description of the database and its purpose is instrumental: 
IACS is a land use cadastre controlling implementation of the European Common Agricultural Policy reform of 1992. The system, including European level land use definitions, was introduced by decree of the European Commission (Council regulations: (EC) $73 / 2009$, (EC) 1122/2009). The purpose of the database was to identify areas that may qualify for European funding of "sustainable management" in agriculture or forestry, i.e. for measures defined under the "European Agricultural Fund for Rural Development" (EAFRD) of the "European Common Agricultural Policy" (CAP).

The practical effect and political motivation of legally harmonising that database with the national forest definition was that farmers could not claim funds on land legally defined as forest-land, and vice versa foresters could not claim funds on areas defined as agricultural areas. Harmonisation of forest definitions thus avoided confusion and facilitated administrative processes regarding distribution of subsides to the forestry sectors.

\subsubsection{Relevance $(Q 1)$ and the risk of political bias $(Q 2)$}

As the above objectives show, there was a general consent on the need to harmonise definitions in the new Federal Forest Act. Due to consent there was no discourse, which implies that there was no risk to argue or to politically instrumentalize data. Yet there is evidence on the other research question, i.e. information relevance:

The legal change on the new forest areas definition implicitly triggered such data needs. After harmonisation of definitions, some of the data on EAFRD-expenditures for management practices on specific land use types, might be provided by NFI information (forest areas) or by the IACS database (agricultural land use types and areas supported by EARFD expenditures). It would be wrong, however, to conclude that there was a political requirement for statistical measures of precision or accuracy. The reason is that one important source of information, the IACS land use information, does not use random and nationally harmonised sampling techniques. It rather relies on the assumption that state authorities and land owners register land use information correctly and comprehensively. The relevant inventory methods are defined by "Guidance for on-the-spot checks (OTSC) and area measurement 2014" (EC, 2014a, DSCG/2014/32). This guidance document demands the generation of maps on different cropping systems by agricultural field-parcel and owner. Owners are supposed to register land use information for their properties which is sometimes cross-checked by visual interpretation of aerial photography, topographic maps, and site-based checks of management practices on a yearly basis (decree (EC) 1122/2009, EC, 2007, Landratsamt Rhein - Neckar - 
Kreis, 2010). It is obvious that if NFI would be harmonised to that database it could potentially provide more science-based evidence than the current practice of "on the spot checks" (Table 10). For this purpose the NFI required additional variables on:

1. short rotation plantations,

2. pastoral management practices (forest cover $\leq 50 \%$ ).

Then, the inventory could be used to monitor or cross-check land use information for the IACS-database and thus contribute to more effective distribution of EU-funds. As described before (Ch. 3.4.3.2), the third NFI responded to these data requirements.

Table 10. $\S 2$ Harmonisation of forest definition with IACS database - Information relevance and transparency of interpretations. (The table presents political parties that contributed to the parliamentary discourse. Politically "relevant" information is characterised by data needs resulting from the redefinition of forest-relevant terms. "Non-transparent" information is quantified by parliamentary statements without supporting evidence.)

\begin{tabular}{|c|c|c|c|c|c|}
\hline \multirow{4}{*}{$\begin{array}{l}\text { Political } \\
\text { parties }\end{array}$} & \multicolumn{3}{|l|}{ Q 1 Relevance } & \multicolumn{2}{|c|}{$\begin{array}{l}\text { Q } 2 \text { Risk of political bias } \\
\text { (confirmed under } 2 \text { conditions) }\end{array}$} \\
\hline & \multirow{3}{*}{$\begin{array}{l}\text { Attribute } \\
\text { (required under new law) }\end{array}$} & \multicolumn{2}{|c|}{ Potential Providers $^{1}$ and Quality ${ }^{2}$} & Lack of transparency & Political motivation \\
\hline & & $\begin{array}{l}\text { NFI } 2002 \\
\text { (with spatial } \\
\text { estimates) }\end{array}$ & $\begin{array}{l}\text { IACS } \\
\text { (without } \\
\text { spatial } \\
\text { estimates) }\end{array}$ & $\begin{array}{l}\text { Assumption without } \\
\text { evidence }\end{array}$ & $\begin{array}{l}\text { Evident from discourse } \\
\text { (explicit or implicit) }\end{array}$ \\
\hline & & TI, BMEL & StMELF, EC & & \\
\hline $\begin{array}{l}\text { SPD, Greens, } \\
\text { Linke, } \\
\text { CDU/CSU, } \\
\text { FDP }\end{array}$ & $\begin{array}{l}\text { Agricultural funding }(€) \\
\text { Forest area (ha) } \\
\text { Agricultural areas (ha) } \\
\text { Area short rotation plantation (ha) } \\
\text { Pastoral management practices } \\
\text { (forest cover } \leq 50 \% \text { ) (ha) }\end{array}$ & $\begin{array}{l}x \\
\text { (harmonisation } \\
\text { needed) } \\
\text { (harmonisation } \\
\text { needed) }\end{array}$ & $\begin{array}{l}\mathrm{x} \\
\mathrm{x} \\
\mathrm{x} \\
\mathrm{x}\end{array}$ & & $\begin{array}{l}\text { Facilitating the funding } \\
\text { of "sustainable" } \\
\text { agricultural- and forestry } \\
\text { practices under ERFAD }\end{array}$ \\
\hline
\end{tabular}

BMEL Bundesministerium für Ernährung und Landwirtschaft (Federal Ministry for Food and Agriculture)

EC European Commission

ERFAD European Agricultural Fund for Rural Development

IACS Integrated Administration and Control System database

NFI National Forest Inventory

StMELF Bavarian State-Ministry of Food, Agriculture and Forestry

TI Thünen Institut (Federal Research Institute for Rural Areas, Forestry and Fisheries)

$1 \quad$ Provider is the provisioning authority

2 Data quality is indicated by the assessment methods and the availability of statistical area estimates. 


\subsubsection{Forest ownership - BWaldG $\S 3$}

\subsubsection{Overview of discourse history and political objectives}

The political discourse did not only result in a new forest definition. Another amendment in $\S 3$ re-organises the definition of forest ownership. Again, there was no parliamentary argumentation and the political motivation for changing the legal regulation became evident only implicitly via the practical consequences describes below.

In the amended law, areas administered by Anstalten des öffentlichen Rechts (public-law institutions), were newly categorised as state forest, instead of Körperschaftswald (communal forest). The change was initiated by recommendation of the agriculture-board (p.m. 17/2184) and had been mutually accepted by all parties throughout the legislative process. The background was the ongoing reorganisation of forest administrations: Federal- and some State administrations (Bundesforstverwaltung and Landesforstverwaltungen) have reorganised themselves to Anstalten des öffentlichen Rechts (public-law institution). In effect, without changing $\S 3$, forest areas under these administrations would have been converted to communal forest, which are not under authority of the BWaldG. There was mutual consent to avoid this transfer and to keep Federal- or State-administered areas under management regulations of the BWaldG and sub-national laws.

\subsubsection{Relevance $(Q 1)$ and the risk of political bias $(Q 2)$}

Eventually, the observation of political consent affected my results in two different ways: Regarding the first research question there was no evidence of a non-transparent or biased discourse. In parliament, there was simply no controversy, nor a need to support arguments by background evidence. Yet, Table 11 shows that the new ownership definition required new types of variables. If NFI is to supply relevant ownership information in the future, it must comply with the amended ownership classification of law: forests under management of Anstalten des öffentlichen Rechts (public-law institution) should distinguish two separate classes, where a new class is required each for state forests under (1) federal- and under (2) state administration (Table 11).

Subsequently, after the amendment of the Federal Forest Act, the NFI 2012 was amended to meet the respective political data requirements. The two new official NFI 3 ownership classes were (by NFI ID in BMELV, 2014): 
34. "Communal forest under exclusive ownership or under exclusive sponsorship of the Land [State] government" [state administration, legally state forest]

35. Communal forest under ownership or under exclusive sponsorship of the national government" [federal administration, legally state forest]"

To allow comparability with previous measurements, the German NFI still keeps the areas under the meaning of the old definition of "communal forest". While the above classes are "communal forest" under NFI, legally they are "state forest". But by adding the respective area estimates to other estimates on areas of state forests under Federal and State property the inventory adjusts definitions for reporting purposes. The reorganisation of NFI-classes thus generates comparable estimates, even though legal and NFI definitions remained different.

Table 11. $\S 3$ Reorganisation of forest ownership - Information relevance and transparency of interpretations. (The table presents political parties that contributed to the parliamentary discourse. Politically "relevant" information is quantified by data needs resulting from the redefinition of forest-relevant terms. "Non-transparent" information is characterised by parliamentary statements without supporting evidence.)

\begin{tabular}{|c|c|c|c|c|c|}
\hline & & Q 1 Relevance & & $\begin{array}{l}\text { Q } 2 \text { Risk of political bi } \\
\text { (confirmed under } 2 \mathrm{co}\end{array}$ & ns) \\
\hline \multirow{3}{*}{\multicolumn{2}{|c|}{$\begin{array}{l}\text { Political } \\
\text { parties }\end{array}$}} & \multirow[t]{3}{*}{$\begin{array}{l}\text { Attribute } \\
\text { (required under new law) }\end{array}$} & $\begin{array}{l}\text { Potential } \\
\text { Providers }^{1} \text { and } \\
\text { Quality }^{2}\end{array}$ & Lack of transparency & Political motivation \\
\hline & & & $\begin{array}{l}\text { NFI } 2002 \\
\text { (with spatial } \\
\text { estimates) }\end{array}$ & \multirow[t]{2}{*}{$\begin{array}{l}\text { Assumption without } \\
\text { evidence }\end{array}$} & \multirow[t]{2}{*}{$\begin{array}{l}\text { Evident from discourse } \\
\text { (explicit or implicit) }\end{array}$} \\
\hline & & & TI, BMEL & & \\
\hline \multirow{2}{*}{\multicolumn{2}{|c|}{$\begin{array}{l}\text { SPD, Greens, } \\
\text { CDU/CSU, } \\
\text { FDP, Linke }\end{array}$}} & $\begin{array}{l}\text { 1. State forest managed by a state's public-law } \\
\text { institutions (Anstalt des öffentlichen Rechts) }\end{array}$ & $\mathrm{x}$ & & \multirow{2}{*}{$\begin{array}{l}\text { Keep Federal- or State- } \\
\text { administered areas } \\
\text { under management } \\
\text { regulations of BWaldG } \\
\text { and sub-national laws }\end{array}$} \\
\hline & & $\begin{array}{l}\text { 2. State forest managed by a national public-law } \\
\text { institution (Anstalt des öffentlichen Rechts) }\end{array}$ & $\mathrm{x}$ & & \\
\hline BMEL & \multicolumn{5}{|c|}{ Bundesministerium für Ernährung und Landwirtschaft (Federal Ministry for Food and Agriculture) } \\
\hline BWaldG & \multicolumn{5}{|c|}{ Federal Forest Act of Germany } \\
\hline $\mathrm{NFI}$ & \multicolumn{5}{|c|}{ National Forest Inventory } \\
\hline $\mathrm{TI}$ & \multicolumn{5}{|c|}{ Thünen Institut (Federal Research Institute for Rural Areas, Forestry and Fisheries) } \\
\hline 1 & \multicolumn{5}{|c|}{ Provider is the provisioning authority } \\
\hline 2 & \multicolumn{5}{|c|}{ Data quality is indicated by the assessment methods and the availability of statistical area estimates. } \\
\hline
\end{tabular}




\subsubsection{Economic rights of "private forestry associations" - BWaldG $\$ \$ 37$ and 40}

\subsubsection{Overview of discourse history and political objectives}

Another outcome of the policy discourse were the amendments in $\S \S 37$ and 40. The following section will present the political backgrounds and explain how motivations affected (Q1) data selection and (Q2) interpretation.

Political motivations become evident from the practical implications: The legal amendments strengthened economic rights of public and private members organised in "private forestry associations" (Forstwirtschaftliche Vereinigungen). Under $\S 37$ (2), they were now allowed to market own timber products and legal cartel regulations on trade restraints did not apply anymore according to $\S 40$ (1). The new law thus supported private forest owners if they were organised in bigger associations. We conclude that a possible implicit motivation of policymakers could be the economic empowerment of these smallholders.

This observation was openly confirmed by explicit arguments voiced in discourse. Such indications were first made by the draft act of the Bundesrat, which initiated that parliamentary discourse in 24.03.2010. The text explained that the background for the amendment of $\S 37$ was increasing completion on the timber market (plenary protocol 45/09 B). To stay competitive on the timber market, forest owners had developed a tendency towards forming ever bigger private forestry associations (plenary protocol 45/09 B). But cartel regulation of the former forest act did not allow them to market products in such big associations. Parliamentary members saw an economic problem in these market restraints. The political motivation behind new sales-rights was therefore the support and better development of smallholders organised in large ownership structures. These associations should eventually increase the competitiveness of members, specifically of small private forest owners (p.m. 17/1220). Similar arguments had already been raised during the amendment of $\S 2$, where parties wanted more harvest in private forests in order to work towards complying with the national Timber Charta and to support the renewable energiessector. Chapter 3.4.2.1 showed that liberals of FDP supported these objectives by NFI results (Box 6).

Responding to these arguments at Bundesrat, the agriculture-board continued support of private forest owners and proposed a draft act that removed trade restraints. Also during the 
second and third reading at parliament (plenary protocol 17/43), the minister of LowerSaxony, Astrid Grotelüschen (SPD), highlighted interests of the regional and private forest owners who should be a market partner on "equal footing with forest industry". She supported the argument claiming that $70 \%$ of forest owners of non-state forest with average sizes of 12.8 ha have already organised themselves in 108 associations and that they depend of sales as timber was their mayor source of income (plenary protocol 17/43, p. 4324). Though she did not refer to any explicit source, these figures were most likely to come from the organisation overseeing, advising and registering private forest owners in Lower-Saxony, the Landwirtschaftkammer Niedersachsen. Every private forest owner is legally obliged to be member of that organisation, so that one may conclude that information on the number of forest owners was reliable and complete.

Also the coalition of CDU/CSU and FDP wanted to "empower forest owners on the timer market" where competition was growing bigger (Alois Gering CDU/CSU, in: plenary protocol 17/43, p. 4330). In view of the growing stocks in private forests as estimated by the NFI and published by the BMEL forest report 2009, also the opposition of Linke supported arguments to "mobilise timber resources" and to "remove pressure from other forest areas" (Dr. Kirsten Tackmann, in: plenary protocol 17/43, p. 4328). Greens and SPD had no comments on this section.

\subsubsection{Relevance $(Q 1)$ and the risk of political bias (Q2)}

Same as in previously observed situations of political consent, only few sources were quoted in support of political motivations and no assumption was made without basis. As shown in Table 12, I conclude that there was no evidence of non-transparent or biased interpretations.

Yet, we do have evidence on the other topic of research, i.e. data relevance. The recognition of the importance of timber resources from "private forestry associations" required reorganisation of variables on ownership structures. That information should ideally measure ownership according to the legal classification of ownership associations. The law allows 3 possible types of private forestry associations (legal definition in Table 7): There can be associations of (1) private forest owners (Genossenschaft = cooperation), of (2) State-property members, and of (3) Federal property members. In any case, even under Federal or Stateownership, the association legally forms a private entity. In response to these requirements the third NFI included 3 new ownership classifications describing the 3 possible options of private forestry associations. Listed by NFI ID (BMELV, 2014), these are: 
43. "Cooperative forest assigned to private forest

44. Private forest under exclusive ownership or under exclusive sponsorship of the State government

45. Private forest under exclusive ownership or under exclusive sponsorship of the Federal government"

Table 12. $\S \S 40,37$ Strengthening economic rights - Information relevance and transparency of interpretations. (The table presents political parties that contributed to the parliamentary discourse. Politically "relevant" information is characterised by the sources consulted in parliament. "Non-transparent" information is quantified by parliamentary statements without supporting evidence.)

\begin{tabular}{|c|c|c|c|c|c|c|}
\hline \multirow{4}{*}{$\begin{array}{l}\text { Political } \\
\text { parties }\end{array}$} & \multicolumn{4}{|l|}{ Q 1 Relevance } & \multicolumn{2}{|c|}{$\begin{array}{l}\text { Q } 2 \text { Risk of political bias } \\
\text { (confirmed under } 2 \text { conditions) }\end{array}$} \\
\hline & \multirow{3}{*}{$\begin{array}{l}\text { Attribute } \\
\text { (by statement about forest fact or required under } \\
\text { new law) }\end{array}$} & \multicolumn{3}{|c|}{ (Potential) Providers ${ }^{1}$ and Quality ${ }^{2}$} & \multirow{3}{*}{$\begin{array}{l}\begin{array}{l}\text { Lack of } \\
\text { transparency }\end{array} \\
\text { Assumption } \\
\text { without } \\
\text { evidence) }\end{array}$} & \multirow{3}{*}{$\begin{array}{l}\begin{array}{l}\text { Political } \\
\text { motivation }\end{array} \\
\text { Evident } \\
\text { from } \\
\text { discourse } \\
\text { (explicit or } \\
\text { implicit) }\end{array}$} \\
\hline & & $\begin{array}{l}\text { NFI } 2002 \\
\text { (with } \\
\text { spatial } \\
\text { estimates) }\end{array}$ & $\begin{array}{l}\text { Private } \\
\text { owners } \\
\text { cadastre } \\
\text { (without } \\
\text { spatial } \\
\text { estimates) }\end{array}$ & No data & & \\
\hline & & TI, BMEL & $\begin{array}{l}\text { Länder, } \\
\text { Lwk }\end{array}$ & & & \\
\hline $\begin{array}{l}\text { SPD and } \\
\text { Greens }\end{array}$ & & & & & & $\begin{array}{l}\text { Support } \\
\text { small-scale }\end{array}$ \\
\hline $\begin{array}{l}\text { CDU/CSU } \\
\text { and FDP }\end{array}$ & $\begin{array}{l}\text { Percent of non-state forest owners (average size of } \\
12.8 \mathrm{ha} \text { ) organised in private forestry associations } \\
\text { Forest area under private ownership (ha) } \\
\text { Private forest areas managed by associations of } \\
\text { private forest owners (Genossenschaft = } \\
\text { cooperation) } \\
\text { Private forest areas managed by associations of } \\
\text { state-property members } \\
\text { Private forest areas managed by associations of } \\
\text { federal property members } \\
\text { Yearly increment of growing stocks ( } \mathrm{m}^{3} / \mathrm{yr} \text { ) } \\
\text { Exploitation of growing stock }\left(\mathrm{m}^{3}\right)\end{array}$ & $\mathrm{x}$ & $\mathrm{x}$ & $x$ & & $\begin{array}{l}\text { forest } \\
\text { owners } \\
\text { organised } \\
\text { in larger } \\
\text { associations }\end{array}$ \\
\hline DIVIEL & \multicolumn{6}{|c|}{ Bundesministerium für Ernährung und Landwirtschaft (Federal Ministry for Food and Agriculture) } \\
\hline Länder & \multicolumn{6}{|c|}{ Federal States of Germany } \\
\hline LwK & \multicolumn{6}{|l|}{ Landwirtschaftkammer Niedersachsen } \\
\hline $\mathrm{NFI}$ & \multicolumn{6}{|l|}{ National Forest Inventory } \\
\hline $\mathrm{TI}$ & \multicolumn{6}{|c|}{ Thünen Institut (Federal Research Institute for Rural Areas, Forestry and Fisheries) } \\
\hline 1 & \multicolumn{6}{|c|}{ Provider is the provisioning authority } \\
\hline 2 & \multicolumn{6}{|c|}{ Data quality is indicated by the assessment methods and the availability of statistical area estimates. } \\
\hline
\end{tabular}




\subsection{7 “Good practice in forestry”-BWaldG $\S 11$}

\subsubsection{Overview of discourse history and political objectives}

Probably the most relevant topic to forest policy was the parliamentary discussion on the introduction of legally-binding standards of good practice in forest management in $\S 11$, BWaldG. As I did in the previous chapters, I first introduce the political discourse and elaborate motivations that led to the legal amendment. In subsequent analysis these background motivations shall explain the two main topics of research, i.e. (1) data relevance and (2) the risk of political bias within interpretations.

As I have shown in the introductory part of this thesis (Ch. 1.1.6), the discussion of legally binding management standards did not start in German parliament. It was in discussion globally since 1992 when the United Nations Conference on Environment and Development adopted the Forest Principles and the Agenda 21 in Rio de Janeiro. These agreements were not yet legally binding. In order to change this situation, since its establishment by the United Nations Economic and Social Council (ECOSOC) in 2000, the United Nations Forum on Forests (UNFF) had strived towards the implementation of legally binding standards ever since. Many criteria and indicator processes such those of the Forest Europe "Report on sustainable forest management in Europe" and United Nations Food and Agricultural Organisation's (FAO) "Global Forest Resources Assessment" (Global FRA) were initiated or refined in the wake of that discourse. Yet the measurement of political achievements was difficult because there was neither a legally binding definition nor an explicit mandate formulating monitoring requirements.

In Germany the idea of setting minimum requirements of "good practice in forestry" came to parliamentary attention by an environmental report to the government which was submitted by the German Advisory Council on the Environment (SRU) on 14.03. 2000 (p.m. 14/3363): The representatives of SRU recommended the definition of minimum requirements for "good practice in forestry" and to integrate interests of forestry and nature conservation (Box 7). The purpose was to better distinguish voluntary management practices from obligatory ones and improve legal certainty about the applicability of other legal regulations such as those on "intervention in nature and landscape" ( $\S 14,15$ Federal Nature Conservation Act) (SRU, 2000, p. 72). In response and by request of the Federal Agency of Nature Conservation (BfN), Winkel and Volz (2003) developed a list comprising 17 criteria of "good practice in forestry" (cf. Annex V). The scientific definition of these criteria was based on a literature review and 
on expert-workshops assessing the environmental effect of different forest management practices.

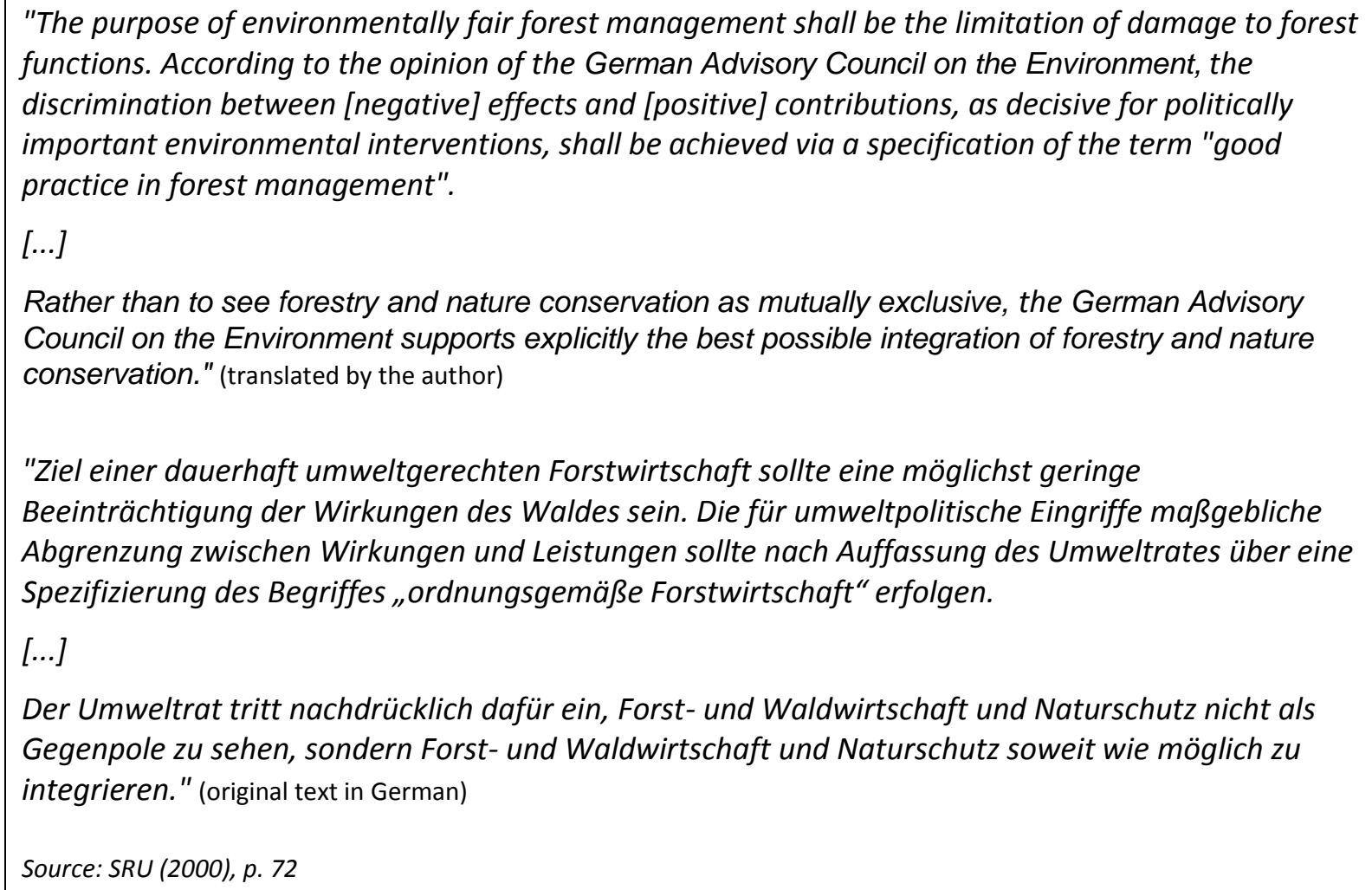

Der Umweltrat tritt nachdrücklich dafür ein, Forst- und Waldwirtschaft und Naturschutz nicht als Gegenpole zu sehen, sondern Forst- und Waldwirtschaft und Naturschutz soweit wie möglich zu integrieren." (original text in German)

Source: $\operatorname{SRU}(2000)$, p. 72

Box 7. SRU policy advice to a legally-binding implementation of standards of good practice

These recommendations entered the parliamentary discourse in 2004. Bundestag members from centre-left SPD and Greens demanded a legal amendment including the definition of standards of "good practice in forestry" (p.m. 15/4516). The political motivation was to enforce nature conservation interests as formulated by the objective of "near-natural forest management" under the coalition contract of then-governing centre-left SPD and Greens (p.m. 15/4516).

However, in the following two legislative periods under politically more conservative coalitions of CDU/SPD and CDU/FDP, the introduction of management standards failed to receive the required majority and in 2010, the Bundesrat decided that introduction of management standards was unnecessary because management regulations under $\S 11$ would be enough to "adequately" regulate forest management (p.m. 45/09B). Only after 
recommendation of the agricultural board, $\S 11$ partly extended the existing requirements of afforestation and reforestation by obligations to "sufficiently account for":

"1. forest functions as an archive of natural- and cultural history and

2. with regard to public parks, gardens and burial-grounds, the preservation of monuments."

The formulation of the above criteria was fairly general, and did not mention any specific management requirements or indicator variables that could have served the measurement of "good practice" in forest management. Also in other sections of the legal amendment, there were no explicit minimum requirements. The practical effects of such indistinct definitions on forest management provide indication on the question of political motivations:

Vague definitions had the (probably desired) effect that forestry operations remained largely unrestricted as long as they complied with the rules of the Federal Nature Conservation Act and did not affect protected species or their habitats. It is to note, however, that Länder may implement additional rules of good practice by state-laws. Still, on the federal level, the rather broad definition of the new forest act, even clear-cut areas would sometimes qualify as "good practice", if reforested and if rotation was more than 20 years (BWaldG $\S 2$ ). The same holds true for building forest roads, forestry access tracks or heavy-impact management practices involving disturbance such as soil compaction, tillage or melioration. By vague definitions the law eventually maintained the status quo of low state regulation and enforced economically oriented forest management practices and interests of the forestry sector. These observations indicate that the economic support of the timber sector, via deregulation was an implicit political motivation for the definition of "good practice" in BWaldG $\S 11$.

Another probably desired effect of rejecting legally binding management standards was to limit monetary burden of the state. Under the Nature Conservation Act BNatSchG $\S 68$, forest owners may claim compensation payments for legal restrictions when economic loss is similar to "expropriation" (Enteignung). An example is limited income due to restrictions of harvests or due to a ban on dead-wood extraction. Up until now, such regulations apply only to some protected areas, but if $\S 11$ defined them "good practice", the restrictions would become legally binding on all German forest lands. In effect, compensation payments under the Nature Conservation Act BNatSchG $\S 68$ would have applied on larger areas and caused a severe monetary burden to the State. To illustrate these burdens, Thoroe et al. (2003), summarised potential payments that would have resulted from legally binding management 
standards (e.g. $7 €-145 €$ per biotope tree). The prospect of such burden probably deterred the conservative politicians from implementing these management standards.

\subsubsection{Relevance $(Q 1)$ and the risk of political bias $(Q 2)$}

Having described political motivation of the respective parties, the following elaborates if these motivations explain (Q1) relevance of information and if (Q2) non-transparent, i.e. unverifiable sources allowed these motivations to bias decision-making.

Regarding the question of relevance, the initiation of policy discourse by recommendations of SRU indicates the political acceptance and relevance of qualitative policy advice. The discourse further shows that political motivations, which were either more in favour of regulation and conservation, or in favour of economic interests led to very different interpretations and data needs:

While CDU/CSU and FDP followed the interpretation of the BMEL forest report 2009 and looked at "good practice" as those measures that:

a) maintain forest area and

b) maintain areas under certification schemes,

Greens and SPD followed SRU recommendations and interpreted "good practice" differently as:

a) the implementation of "good practice" management standards suggested by Winkel and Volz (2003) and

b) the achievement of a "near-natural forest state", i.e. a state of forests that fulfils the "favourable" standards as defined by EU Habitats Directive.

Table 13 shows that depending on these different views, the choice, i.e. relevance of inventory-based evidence, and the interpretation of such evidence varied significantly. The centre-right coalition argued that Germany's forest cover of $31 \%$, certified forest areas of $70 \%$ (PEFC, FSC and Naturland) and the relatively low loss of bird species were an adequate proof of the sustainability of forest management. They concluded that forestry does not require additional regulations.

The opposition of SPD and Greens, in contrast, interpreted that the current forest management be unsustainable, specifically regarding the 17 management standards defined as "good 
practice in forest management" by the BfN publication in Winkel and Volz (2003). They supported their arguments by evidence published in the national forest report (BMELV, 2009): NFI estimates on forest cover, age and dead-wood, as well as data from the German Weather Service (DWD). Other data was provided by the forest health-monitoring from the EU-wide ICP-Forests Level II programme. Altogether, this evidence led to the conclusion that current management practices in combination with "extreme" weather conditions and air pollution would aggravate problems of "extensive" forest damage and further limit extent of old forests and dead-wood stocks.

Yet, the quoted sources provided evidence on only some of the targeted achievements. This observation points to the second research question: the risk of political bias as a result of nontransparent, i.e. unverifiable evidence. Verifiable evidence included NFI data on "deadwood decomposition stages" ("good practice" criterion 9) and "age structure" (criterion 7). Yet, other aspects of good practice remained without proof: The consulted BMEL-national forest report, did not provide information on variables such as utilisation of "eyrie trees" (criterion 8), "fertilisation" (criterion 16) or the "introduction of genetically modified organisms" (criterion 13). For this reason the overall statement on the positive status of good practice was without basis and merely an assumption. Referring to the research questions, we may infer that interpretations, especially those of the opposition, remained non-transparent. For this reason Table 13 shows that interpretations carried a risk of being politically biased towards the respective motivations.

There were indications that the lack of verifiable evidence from commonly quoted - and probably trusted sources - such as the NFI and others limited perceived trustworthiness of political conclusions. For this reason, the lack of evidence prompted a CDU/CSU member to the spontaneous interruption: "How does [ecosystem] stress express itself inside forests?" (plenary protocol 17/43) The question remained without reply. That notion can be seen as typical for the parliamentary discourse where lack of mutually accepted evidence hindered consent. Eventually, it was impossible for the parliament to comprehensively judge the necessity of binding management regulations. Lack of convincing and mutually accepted evidence eventually resulted in the rejection of opposition-supported quality standards. This observation indicates that there was a risk of politically biased interpretations, but they were met with suspicion and did not necessarily enforce the arguments.

Since 2012, the third NFI had addressed some of these data gaps. Table 14 shows the criteria of good practice defined by Winkel and Volz (2003) and relates them to the number of NFI 
variables measuring the respective aspects. Information that is not assessed by the NFI such as "soil tilling" (Criterion 5), "use of pesticides, herbicides and wood preservatives inside forest" (Criterion 11) and "fertilisation" (Criterion 16) are already available via the national inventories on forest health (WZE) and forest soils (BZE). On a 4 x $4 \mathrm{~km}$ grid the inventories measure pesticides, herbicides and fertilisation and compare them to the chemical composition of soils (cf. manuals in: Wellbrock et al., 2006). The inventories further measures variables on soil tilling activities (Criterion 5) and analysis thus allows inferences on the foresters' compliance with good practice criterion No. 5. If we look at Table 14 and further compare the definitions of good practice standards (Annex V) with provisions of data via national genetic inventory of BLE, then we see that also the remaining criteria were matched by available sources. Criterion 9 "integrative nature conservation in forestry" required measurement of threatened tree species, and compliance with the ban in accordance to Criterion 13 required evidence on genetically modified trees. Such information was available via the national genetic inventory conducted under the umbrella of the German Federal Agency for Agriculture and Food (BLE). On a small number of experimental plots, it provided information on the area of plantations with genetically modified trees, genetic conservation, genetic hybridisation and the abundance of rare tree species (Janßen et al., 2014). 
Table 13. $\S 11$ Implementation of management standards - Information relevance and transparency of interpretations. (Politically "relevant" information quantified by the sources consulted in parliament. "Non-transparent" information quantified by parliamentary statements without supporting evidence.)

\begin{tabular}{|c|c|c|c|c|c|c|c|c|c|c|}
\hline \multirow{4}{*}{$\begin{array}{l}\text { Political } \\
\text { parties }\end{array}$} & \multicolumn{8}{|l|}{ Relevance } & \multicolumn{2}{|c|}{$\begin{array}{l}\text { Risk of political bias } \\
\text { (confirmed under } 2 \\
\text { conditions }\end{array}$} \\
\hline & \multirow[t]{3}{*}{ Data use } & \multicolumn{7}{|c|}{ 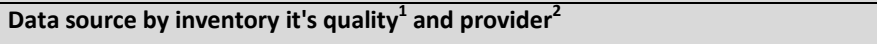 } & \multirow{2}{*}{$\begin{array}{l}\begin{array}{l}\text { Lack of } \\
\text { transpa } \\
\text { rency }\end{array} \\
\text { Assump } \\
\text { tion } \\
\text { without } \\
\text { evidenc } \\
\text { e }\end{array}$} & \multirow{2}{*}{$\begin{array}{l}\text { Political } \\
\text { motivat } \\
\text { ion }\end{array}$} \\
\hline & & $\begin{array}{l}\text { NFI } \\
2002 \\
\text { (with } \\
\text { spatial } \\
\text { estimat } \\
\text { es) }\end{array}$ & $\begin{array}{l}\text { Red List } \\
\text { (withou } \\
\text { t spatial } \\
\text { estimat } \\
\text { es) }\end{array}$ & $\begin{array}{l}\text { Level II } \\
\text { (with } \\
\text { spatial } \\
\text { estimat } \\
\text { es) }\end{array}$ & $\begin{array}{l}\text { Climate } \\
\text { Data } \\
\text { Center } \\
\text { (with } \\
\text { spatial } \\
\text { estimat } \\
\text { es) }\end{array}$ & $\begin{array}{l}\text { Certifi- } \\
\text { cation } \\
\text { (withou } \\
\text { t spatial } \\
\text { estimat } \\
\text { es) }\end{array}$ & $\begin{array}{l}\text { Bird } \\
\text { monito- } \\
\text { ring } \\
\text { (withou } \\
\text { t spatial } \\
\text { estimat } \\
\text { es) }\end{array}$ & No data & & \\
\hline & & $\begin{array}{l}\text { TI, } \\
\text { BMELV }\end{array}$ & $\begin{array}{l}\text { BfN, } \\
\text { IUCN }\end{array}$ & $\begin{array}{l}\text { TI, } \\
\text { BMELV }\end{array}$ & DWD & $\begin{array}{l}\text { FSC, } \\
\text { PEFC }\end{array}$ & $\begin{array}{l}\text { DDA, } \\
\text { BfN }\end{array}$ & & & \\
\hline $\begin{array}{l}\text { SPD and } \\
\text { Greens }\end{array}$ & $\begin{array}{l}\text { Implementation of } \\
\text { standards regarding } \\
\text { "good practice" in forest } \\
\text { management (17 criteria) } \\
\text { Dead-wood by } \\
\text { decomposition stage } \\
\text { Age-structure of forests } \\
\text { Number of threatened } \\
\text { vascular plants } \\
\text { Deposition in } \\
\text { precipitation (averaged } \\
\text { per year) [kg ha-1 a-1]: } \\
\text { - Sulphur SO }{ }_{4}-\mathrm{S} \\
\text { - Nitrogen NOx-N and } \\
\quad \mathrm{NH}_{4}-\mathrm{N} \\
\text { Crown transparency (\%) } \\
\text { Variability of } \\
\text { temperatures averaged by } \\
\text { year } \\
\text { Change of regional and } \\
\text { seasonal precipitation } \\
\text { patterns }\end{array}$ & 1 & 1 & 2 & 1 & & & 1 & 1 & $\begin{array}{l}\text { Regulate } \\
\text { the } \\
\text { forestry } \\
\text { sector }\end{array}$ \\
\hline \multicolumn{2}{|c|}{ Sum SPD and Greens } & 2 & 1 & 3 & 2 & & & 1 & 1 & \\
\hline $\begin{array}{l}\text { CDU/CSU, } \\
\text { FDP, } \\
\text { Linke }\end{array}$ & $\begin{array}{l}\text { Growing stock trend } \\
\left(\mathrm{m}^{3} / \mathrm{yr}\right) \\
\text { Tree species number } \\
\text { National forest cover }(\%) \\
\% \text { Area certified (ha) } \\
\text { Woodland bird indicator } \\
\text { Dead wood }\left(\mathrm{m}^{3}\right)\end{array}$ & $\begin{array}{l}1 \\
1 \\
1 \\
1 \\
1\end{array}$ & & & & 1 & 1 & & & $\begin{array}{l}\text { Maintain } \\
\text { low } \\
\text { regula- } \\
\text { tion of } \\
\text { the } \\
\text { forestry } \\
\text { sector }\end{array}$ \\
\hline Sum CDU/C & SU, FDP, Linke & 4 & & & & 1 & 1 & & & \\
\hline $\mathrm{BfN}$ & \multicolumn{10}{|c|}{ Bundesamt für Naturschutz (Federal Agency for Nature Conservation) } \\
\hline BMEL & \multicolumn{10}{|c|}{$\begin{array}{l}\text { Bundesamt fur Naturschutz (Federal Agency for Nature Conservation) } \\
\text { Bundesministerium für Ernährung und Landwirtschaft (Federal Ministry for Food and Agriculture) }\end{array}$} \\
\hline BWaldG & \multicolumn{10}{|c|}{ Federal Forest Act of Germany } \\
\hline Certification & \multicolumn{10}{|c|}{ Programme for the Endorsement of Forest Certification Schemes (PEFC), Forest Stewardship Council (FSC), Naturland } \\
\hline DDA & \multicolumn{10}{|c|}{ German umbrella organisation of ornithologists } \\
\hline DWD & \multicolumn{10}{|l|}{ German Weather Service } \\
\hline IUCN & \multicolumn{10}{|c|}{ International Union of Conservation of Nature } \\
\hline Level II & \multicolumn{10}{|c|}{$\begin{array}{l}\text { European forest health inventory on a subsample of a } 16 \text { x } 16 \text { grid of permanent sample plots (UNECE ICP Forests Programme Co- } \\
\text { ordinating Centre, 2016) }\end{array}$} \\
\hline $\mathrm{NFI}$ & \multicolumn{10}{|c|}{ National Forest Inventory } \\
\hline $\mathrm{TI}$ & \multicolumn{10}{|c|}{ Thünen Institut (Federal Research Institute for Rural Areas, Forestry and Fisheries) } \\
\hline 1 & \multicolumn{10}{|c|}{ Provider is the provisioning authority } \\
\hline 2 & \multicolumn{10}{|c|}{ Data quality is indicated by the assessment methods and the availability of statistical area estimates. } \\
\hline 3 & \multicolumn{10}{|c|}{ Information on relevant field measurements for "good practice" derived from standards defined in: Winkel and Volz (2003) } \\
\hline
\end{tabular}


Table 14. Required variables on "Good practice in forest management" and NFI provisions (in number of attributes to be observed/measured in field). Information on requirements is derived from standards of "good practice" in forest management as defined by Winkel and Volz (2003). Provisions are derived from the respective inventory manuals.

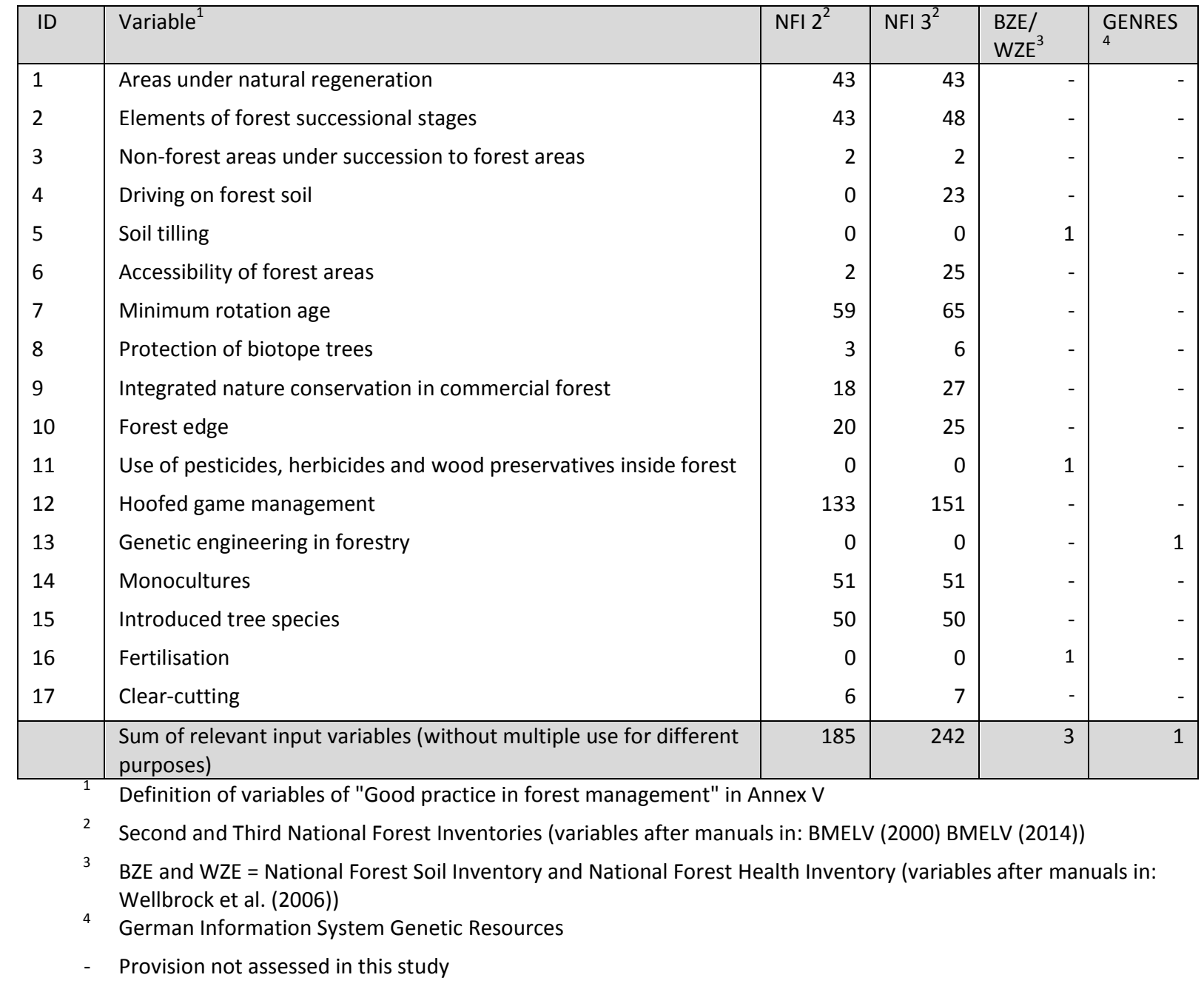




\subsubsection{The NFI mandate and international reporting obligations- BWaldG}

\section{$\S 41 a$}

The amendment of $\S 41 \mathrm{a}$ formulates the NFI mandate and seeks to satisfy the abovementioned data requirements. This section wants to explain political motivations and data needs that were background to the decision on that legal amendment. The elaboration of these background requirements shall contribute to the research question of data relevance (Q1). The second research question of political bias is irrelevant at this point because, there was neither discourse nor risk to misinterpret scientific evidence.

The data requirements were evident from Section 41a, BWaldG. It formally mandates BMEL and the NFI to monitor variables for international reporting obligations, primarily those under two different agreements:

1) the Habitats Directive (Council Directive 92/43/EEC, Article 17) and

2) the Climate Conventions (obligation of Article 7 of the Kyoto Protocol).

The respective reporting formats (Council Directive 92/43/EEC Annex D, COP of the Kyoto Protocol, 2005; and Penman et al., 2003) define attributes and quality requirements as soughtafter by the first research question (Q1). Table 15 summarises how NFI has responded to these obligations: For the purpose of compiling carbon emission reports, the so-called "National Inventory Reports" (NIR) (report in: Strogies and Gniffke, 2014), NFI assessed new variables on land use and land use change (BMELV, 2014). Improved national volume functions for the estimation of above-ground carbon stocks (Strogies and Gniffke, 2014) further amended variables on dead-wood measurements (BMELV, 2014). As an example, in the German NFI, the redefinition of the dead-wood thresholds from $20 \mathrm{~cm}$ to $10 \mathrm{~cm}$ (cf. BMELV, 2000 with BMELV, 2014) harmonised standards with the IPCC guidelines (Penman et al., 2003) for more consistent reporting under UNFCCC.

Also, additional NFI variables on indicators of habitat types, eutrophication and measurements of invasive woody plants have responded to reporting obligations on biodiversity and the so-called "conservation status" after Article 17 of the EC-Habitats Directive. Table 15 shows a summary on the number of variables measured for that specific purpose. More details on the technical details of inventory design, methods of measurement and analysis of NFI variables for that specific biodiversity reporting obligation follow later in Chapter 4. Here, results will show that the NFI did considerably enhance the knowledge base 
by scientific and transparent information that is based on science based observations rather than on expert option.

Further political motivations for the new NFI-mandate became evident from observations made in the present chapter. In Section 3.4.7, analysis showed that the absence of relevant and mutually accepted variables on "good practice" in forest management hindered consent and eventually lead to the failure of implementing legally-binding management standards. Results indicated that the objective of the new mandate was to overcome these shortcomings and inform future discussions more comprehensively. As a consequence, the new NFI of 2012 included additional variables on biodiversity (Table 14) that matched some of the criteria of "good practice in forest management" as defined by Winkel and Volz (2003).

Another motivation of extending the scientific knowledge-base was the need to monitor sites that could potentially qualify as strictly protected nature reserves as required under the $10 \%$ "wilderness target" of the National Biodiversity- and the National Forest Strategies (BMU, 2007; BMEL, 2008). Box 8 shows that the idea came to parliamentary attention on 14.03.2000 when a panel of scientists at SRU recommended better cooperation between institutions of forestry and nature conservation (SRU, 2000). Foresters and conservationists were advised to reconcile controversies, and merge administrative responsibilities. In that cooperation the forestry administration, represented by BMEL and TI should monitor the implementation of biodiversity policies such as the $10 \%$ target. SRU recommended that the NFI shall provide such information, especially those relating to the identification of potential wilderness reserves (cf. SRU, 2000).

Good experience and trust in NFI data quality could further explain the politically perceived value of NFI information. At least, this became evident from discussions prior to the parliamentary discourse. In 2007, even before the legal amendment, the decree on NFI (Bundesrat, p.m. 200/07) had already introduced the new mandate. In the course of drafting the decree, advisors to the Environment Agency (UBA) had highlighted positive experiences with the NFI and recommended its extension for carbon-emission reports (UBA, 2012). They also expected that the new NFI would improve remaining shortcomings regarding the estimation of areas of land use change and C-losses from dead wood. Eventually, the third NFI would "make possible highly precise conclusions with regard to forest land area and pertinent changes" (UBA, 2012: 522, translated by the author). In its decision, the parliament followed these recommendations from the scientific community and formally extended the NFI mandate towards reporting carbon sequestration. 
According to a calculation by BMEL (Schmitz, 2013), the extension of the NFI protocol has eventually doubled the federal spending on the third inventory (now: 6.270.000 $€$ ) as compared to the second, whereas spending of states remained almost unchanged $(15.113 .000$ $€)$. The documents do not reveal however, how or where BMEL acquired the additional financial resources. In general, for the present research, assumptions on financing were difficult to prove as monitoring costs can potentially be covered by a very complex mix of funds from Federation, States and the European Commission (e.g. Life). In addition, the available financial reports of Federal spending by BMU and BMEL do not date back to the 2002 reference date of NFI 2. Whereas those with the newer 2012 reference date (NFI 3) are available, but they do not clearly distinguish additional costs resulting from additional biodiversity variables. Lastly, considering the fact that the extended inventory mandate bases on a coalition contract where SPD and Greens highlighted the political significance of the extended monitoring mandate, we might hypothesise that the government assigned additional resources to BMEL to cover costs. It is at least unlikely to imagine that the ministry would have accepted to take over BMU monitoring responsibilities without being compensated adequately, nor that BMU, which had a much smaller budget ${ }^{15}$, to take over costs. Later discussions on the new distribution of monitoring efforts finally indicated that both, BMU and BMEL supported the new distribution of monitoring efforts by sharing "synergies" and reduction of costs (cf. Sachteleben and Behrens, 2010a). The new inventory mandate was thus most likely to be based on some sort of compromise creating a win-win situation for both of the involved ministries.

Finally, the perceived benefit of extending the NFI mandate was to reduce monitoring costs by avoided duplication of monitoring effort (Sachteleben and Behrens, 2010a). Before, BfN had been the only responsible authority for biodiversity monitoring programmes. At the same time, the NFI also assessed similar variables such as deadwood, forest structures and tree species. Authorities and BfN and TI believed that shared work effort could avoid that duplication and reduce costs (Sachteleben and Behrens, 2010a). How exactly this reduction had been achieved and how NFI contributed will be explained in Chapter 4.

\footnotetext{
${ }^{15}$ Federal spending in 2012 on resorts:

BMUB 1.590 .524 tsd. $€=0,51 \%$ of overall federal budget,

BMEL $\quad 5.280 .066$ tsd. $€=1,69 \%$ of overall federal budget

Source: Federal Finance Ministry, Federal Finance Report (2012) available online https://www.bundeshaushaltinfo.de
} 
Table 15. Data requirements of international reporting obligations after BWaldG§ 41a and NFI provisions (in number of attributes to be observed/measured in field). Information on data use is derived from reporting formats

\begin{tabular}{|l|r|}
\hline Reporting obligation (after BWaldG § 41a) & NFI 2 NFI 3 \\
\hline $\begin{array}{l}\text { Habitats Directive } \\
\text { (reporting "conservation status" after Article 17 and Annex D) }\end{array}$ & 57 \\
$\begin{array}{l}\text { UNFCCC } \\
\text { (reporting carbon emissions after COP of the Kyoto Protocol, 2005; and Penman et al., 2003) }\end{array}$ & 26 \\
\hline Sum of variables (without multiple use for different purposes) & 80 \\
\hline
\end{tabular}

"Forest management that accounts for both, issues of forestry and nature conservation, needs a differentiated designation of priority areas, for instance as absolute reserves. According to the opinion of the German Advisory Council on the Environment, the qualitative and quantitative inventory of area- and development potentials is an important conceptual basis for the purpose of designating priority areas inside forests and for such areas' spatial integration. This is just what the National Forest Inventory and the forest management units already do for aspects of wood production." (translated by the author)

"Eine Waldnutzung, die sowohl forstliche als auch naturschutzfachliche Belange adäquat berücksichtigt, bedarf der differenzierten Festlegung von Vorrangflächen beispielsweise als Totalreservate. Eine wichtige planerische Voraussetzung für die Festlegung solcher Vorrangflächen im Wald sowie deren räumliche Integration ist nach Ansicht des Umweltrates die systematische, qualitative und quantitative Erhebung der Flächen- und Entwicklungspotentiale. Dies leisten für die holzproduktionsrelevanten Aspekte der Waldbewirtschaftung unter anderem die Bundeswaldinventur sowie die Forsteinrichtungswerke." (original text in German)

Source: SRU (2000) in: p.m. 14/3363, p. 72)

Box 8. SRU policy advice to use NFI for identifying areas that qualify as strictly protected nature reserves

\subsubsection{Relevance of data quality}

The previous chapters have analysed the question of data requirements by two aspects, (1) data providers and (2) attributes of information. This chapter seeks to contribute to the third aspect that might guide information selection: (3) data quality. Statistical characterisations of data quality such as estimated precision and accuracy were not quoted in parliament. Hence it is difficult to conclude that these measures were actually policy-relevant. Yet, it is interesting to see that information generated by sample-based data assessment programmes, such as the NFI, were more successful in convincing the parliament than other sources such as case studies. We may conclude that the information derived relevance by its ability to generate large-area, i.e. estimates on the federal or the state level. 
Additional indication of data quality is the extent to which data had to be aggregated in order to "qualify" as a political data source. There essentially are 3 possible levels of data accumulation:

1. Field observations,

2. Quantitative results of analysis algorithms (e.g. estimates of the total area) and

3. Qualitative interpretations (cf. Ch. 3.3.3).

By quantifying quoted sources by their level of data accumulation, the following section assesses the relevance of such levels as a quality criterion.

The arrows in Figure 5 illustrate the flow of information between the different levels of data aggregation, from the original observations, to the eventual decision. It shows that parliamentarians never used original data to make own analysis for the purpose of a specific argument. Instead the relied on existing results from analysis that was somehow suitable to support their argumentation, even if the information was not comprehensive enough or designed to support a specific political claim. Such pre-existing information was referenced in four types of discourses, namely in discussions on short rotation-plantations and agroforestry (both $\S 2$ BWaldG), in support of good practice standards in $\S 11$, and in support of private forestry associations ( $\S \S 37,40)$. The qualitative interpretations in form of policy-advice was similarly convincing to decision-makers. Such information affected four decisions in BWaldG. An example is the SRU recommendation to implement management standards in $\S$ 11 (Chapter 3.4.7) or to extend the mandate of the NFI in $\S 41 \mathrm{a}$ (Ch. 3.4.8). Though not all of these recommendations were mutually accepted, they were credible to at least some of the parliamentarians and thus informed the political discourse.

In spite of the observed relevance of large area estimates and the political value of aggregated information, a limitation to observations on data quality criteria becomes evident when looking at those arguments that successfully triggered policy action. Figure 6 shows that in 2010, the governing centre-right coalition of CDU/CSU and FDP held the majority of seats in parliament. Table 16 shows that in all cases of conflict, information was never convincing enough to change the parties' pre-defined opinions. Instead, the pre-defined decisions preferred by the CDU/CSU/FDP coalition remained unchanged and always won the vote. It is interesting to see that evidences used in such arguments were very diverse and this diversity indicates that quality was not a major factor influencing the outcomes of decisions. 
Considerations on data quality may influence policy makers in choosing a specific variable for a specific argument. Yet, above all, political power, i.e. the number of seats (and votes), decides on policy action. Political power thus seemed to be the most important criterion in political decision making.

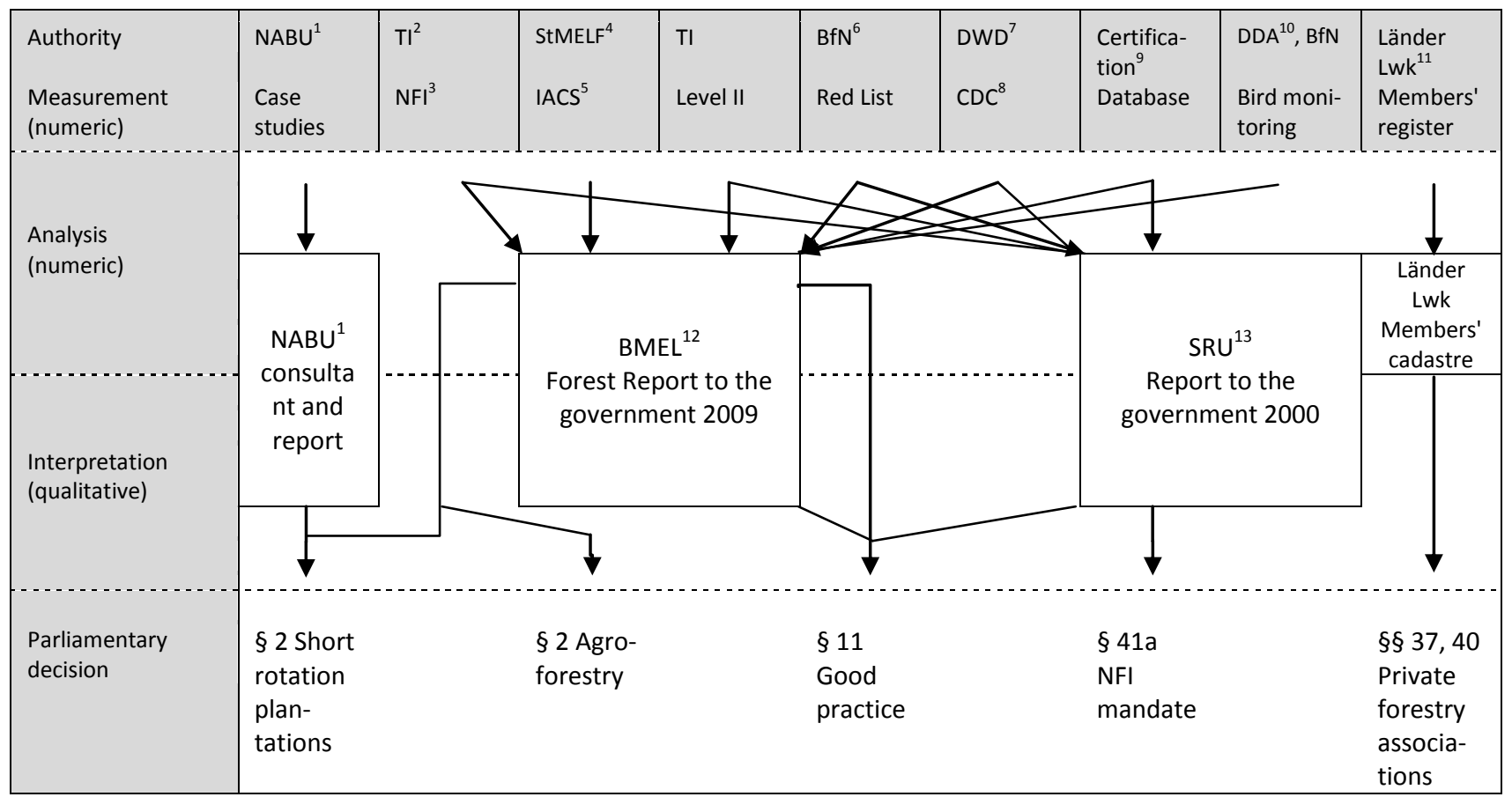

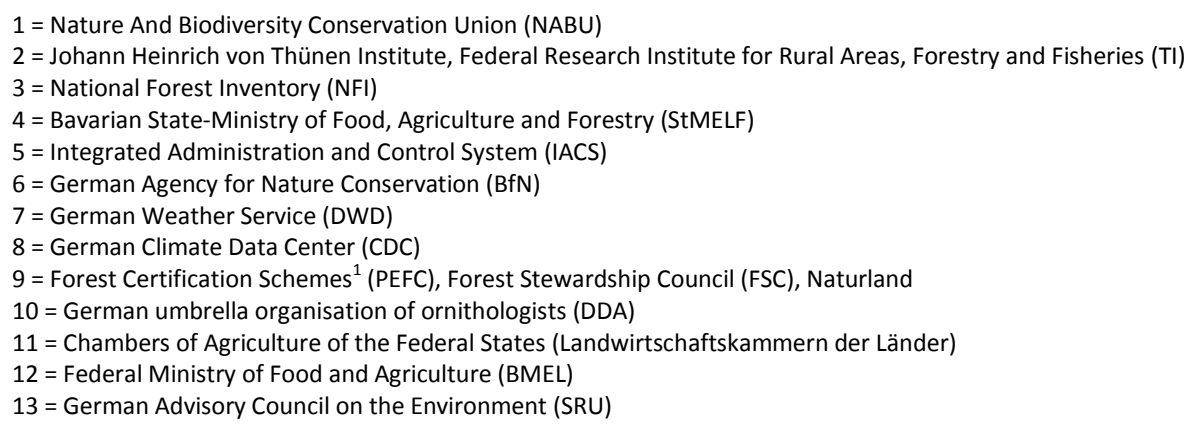

Figure 5. Parliamentary data requirements by consulted authorities and the level of data accumulation. The flow chart shows responsibilities of data aggregation and data transfer between the different authorities that have contributed to the amendment of the Federal Forest Act. Data quality is presented by the level of data accumualtion (measurement, analysis, interpretation) 


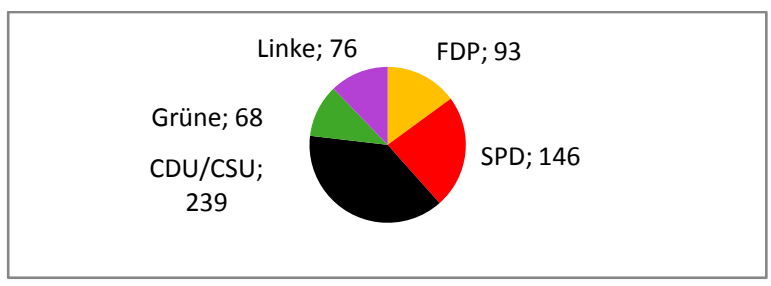

Figure 6. Distribution of seats in the 17th German Bundestag (27.10.2009 - 22.10.2013). Seats by parties after central election in 2009, total number of seats 622 (Der Bundeswahlleiter, 2015)

Table 16. Overview of political motivations, data relevance, transparency of interpretations and decisions. The table presents political parties that contributed to the parliamentary discourse. Politically "relevant" information is quantified by the sources consulted in parliament or by data needs resulting from the redefinition of forest-relevant terms. "Nontransparent" information is quantified by parliamentary statements without supporting evidence.

\begin{tabular}{|c|c|c|c|c|c|c|c|c|}
\hline \multirow[t]{3}{*}{ Topic } & \multirow{3}{*}{$\begin{array}{l}\text { Political parties } \\
\text { (seats in brackets) }\end{array}$} & \multirow[t]{3}{*}{ Political motivation } & \multicolumn{5}{|c|}{ Q 1 Relevance } & \multirow[t]{3}{*}{ Decision } \\
\hline & & & \multicolumn{2}{|c|}{$\begin{array}{l}\text { Data source by } \\
\text { quantitative references }\end{array}$} & \multicolumn{3}{|c|}{ Quality characteristics } & \\
\hline & & & $\mathrm{NFI}^{1}$ & others & $\begin{array}{l}\text { Random } \\
\text { sampling } \\
\text { and } \\
\text { national- } \\
\text { level } \\
\text { estimates }\end{array}$ & $\begin{array}{l}\text { Lack of } \\
\text { transpare } \\
\text { ncy (by } \\
\text { assumptio } \\
\mathrm{n} \text { without } \\
\text { evidence) }\end{array}$ & $\begin{array}{l}\text { Aggregati } \\
\text { on level } \\
\text { of } \\
\text { informati } \\
\text { on } \\
(\mathrm{M}, \mathrm{A}, \mathrm{I})^{2}\end{array}$ & \\
\hline \multicolumn{9}{|c|}{ § 2 "Short rotation plantations" } \\
\hline & $\begin{array}{l}\text { SPD, Greens, Linke } \\
(290)\end{array}$ & $\begin{array}{l}\text { Deter establishment of short } \\
\text { rotation plantations }\end{array}$ & 0 & 1 & - & 1 & 1 & $x$ \\
\hline & $\begin{array}{l}\text { CDU/CSU, FDP } \\
(332)\end{array}$ & $\begin{array}{l}\text { De-regulate forestry on short } \\
\text { rotation plantations }\end{array}$ & 2 & 1 & 2 & & $A, I$ & $x$ \\
\hline \multicolumn{9}{|c|}{$\S 2$ “Agroforestry" } \\
\hline & $\begin{array}{l}\text { SPD, Greens, Linke } \\
(290)\end{array}$ & $\begin{array}{l}\text { Keep agroforestry areas with } \\
\text { "protective functions" under } \\
\text { regulation of BWaldG }{ }^{3}\end{array}$ & 1 & 0 & 1 & 2 & $\mathrm{~A}$ & - \\
\hline & $\begin{array}{l}\text { CDU/CSU, FDP } \\
(332)\end{array}$ & $\begin{array}{l}\text { De-regulate agroforestry on } \\
\text { mountain pastures }\end{array}$ & 2 & 0 & 2 & 2 & $\mathrm{~A}$ & $x$ \\
\hline \multicolumn{9}{|c|}{ § 2 European IACS ${ }^{4}$ database } \\
\hline & $\begin{array}{l}\text { SPD, Greens, Linke } \\
(290)\end{array}$ & \multirow{2}{*}{$\begin{array}{l}\text { Facilitating the funding of } \\
\text { "sustainable" agricultural- and } \\
\text { forestry practices under EAFRD }\end{array}$} & \multirow[t]{2}{*}{0} & \multirow[t]{2}{*}{0} & \multirow[t]{2}{*}{-} & \multirow[t]{2}{*}{0} & \multirow[t]{2}{*}{-} & \multirow[t]{2}{*}{$x$} \\
\hline & $\begin{array}{l}\text { CDU/CSU, FDP } \\
(332)\end{array}$ & & & & & & & \\
\hline \multicolumn{9}{|c|}{ § 3 Ownership } \\
\hline & $\begin{array}{l}\text { SPD, Greens, Linke } \\
(290)\end{array}$ & \multirow{2}{*}{$\begin{array}{l}\text { Keep federal- or state- } \\
\text { administered areas under } \\
\text { management regulations of } \\
\text { BWaldG and sub-national laws }\end{array}$} & \multirow[t]{2}{*}{0} & \multirow[t]{2}{*}{0} & \multirow[t]{2}{*}{-} & \multirow[t]{2}{*}{0} & \multirow[t]{2}{*}{. } & \multirow[t]{2}{*}{$x$} \\
\hline & $\begin{array}{l}\text { CDU/CSU, FDP } \\
(332)\end{array}$ & & & & & & & \\
\hline
\end{tabular}




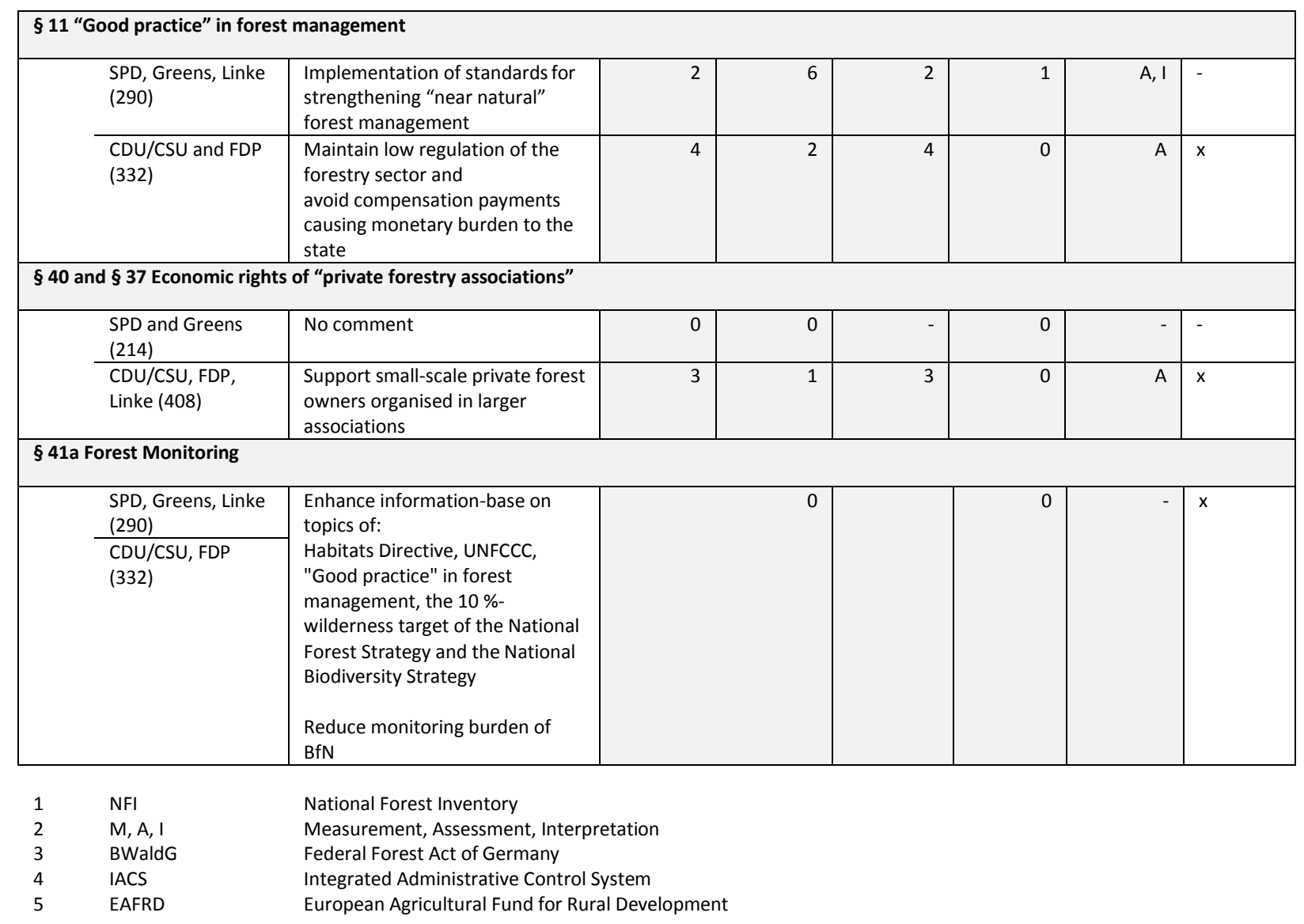

\subsection{Summary and Discussion}

\subsubsection{Information relevance}

With a case study on the political discussion of the amendment of the Federal Forest Act 2010, this chapter contributed evidence on the relevance of forest information in political decision-making-processes. I differentiated 3 components of requirements: 1) attributes, 2) providers 3) quality. I further wanted to explain those requirements by political motivations. For this purpose, I first identified motivations that were explicitly voiced in parliament. Then, in order to exclude bias from wrong assertions and overly positive self-presentation, I identified implicit motivations. These became evident from the practical consequences of favoured decisions. This analysis required an extensive review of the Federal Forest Act, its implications on other laws and the combined effect on real-world problems such as conservation obligations and the distribution of agricultural funds under the European Common Agricultural Policy (CAP). I then identified data requirements, by the kinds of attributes and data providers quoted in support of political motivations. Quality requirements were identified by two methods: the inventory methods (such as sampling design) of a quoted 
reference and the level to which a given reference had been aggregated and condensed before it was quoted in parliament.

Regarding motivations, results showed that the governing coalition of CDU/CSU and FDP was more in favour of economic interests, whereas the opposition of Greens and SPD supported environmental issues: These sector-specific motivations and arguments created very different data needs, in terms of attributes, whereas the selection of providers and quality characteristics seemed to be largely independent of such motivations: Regarding attributes, the conservative coalition of CDU/CSU and FDP tended to select and interpret evidence in favour of economic interests. The relevant attributes mainly came from the NFI and included data on "forest area" and "area under certification schemes". Here, BMEL and the Thünen Institute were the most trusted providers. The coalition interpreted these figures as a valid evidence for both: the achievement of "sustainable forest management" and the redundancy of legally binding management standards. The opposition of SPD, Greens and Linke in contrast argued in favour of environmental conservation and selected attributes measuring environmental threats such as pollution and climate-change, mainly from the forest health inventory. Same as for the opposing coalition of CDU/CSU and FDP, the Thünen Institute and BMEL were the most trusted providers.

Results further showed that political objectives and motivations did not affect quality requirements of parliamentarians. We can rather say that across all political spectra, the NFI and forest health assessments derived relevance by their ability to generate large area, i.e. national estimates. This observation was further confirmed by the NFI mandate in $\S 41 \mathrm{a}$, BWaldG, and its extension towards biodiversity assessments. Previously, as I will show in Chapter 4, biodiversity assessments could often not guarantee the application of principles of statistical sampling and allowed politically biased selection of sites. This risk was removed for at least some of the topics to be assessed, when the NFI took over the corresponding responsibilities. Such an extension of the NFI-mandate was probably expected to improve the knowledge base in decision making, especially with respect to the achievements of "good practice in forest management", the achievements of "conservation status" under the Habitats Directive and the identification and designation of wilderness reserves under the $10 \%$ target of the National Biodiversity- and the National Forest Strategies.

Another quality criterion of political relevance became evident from the level to which quoted sources had been accumulated and condensed. Existing analytic results and qualitative policy advice, both of which are at the higher levels of accumulation, were generally preferred over 
making own analysis for a specific question. This meant that information was communicated more effectively to the political community when it compiled various information sources to inform a specific issue of political interest. This indicates that in order to remain politically relevant, scientists would need to get more involved into the political arena. They need to understand political concerns and decision making problems if they want to produce not only scientifically credible but also politically relevant information.

It is important to note that the abovementioned quality criteria made a data source more likely to be selected only. Yet, it is difficult to conclude that these criteria were the only factor enforcing an argument's ability to convince the parliament. Also the number of seats played an important role, at least in all cases of conflict, the party who held the majority, won the argument.

\subsubsection{Risk of political bias}

Besides analyzing the political relevance of data, this chapter's case-study further contributed evidence on the political instrumentalisation of forest information in decision-makingprocesses. The analysis of risks of political bias based on a political theory presented in Chapters 1.2 and 1.3 which assumed that policy makers tacitly select information and bias interpretations in favour of political interests. In order to test this theory, I analysed two conditions that verified the theory: Political motivations and lack of transparency.

Results showed that though political motivations influenced data choice, there was little evidence for politically motivated bias. Analysis of data relevance showed that it was true that data was selected to serve specific interests such as those of conservation and economics (cf. Ch. 3.5.1). I have also shown that interpretations were sometimes based on unverifiable evidence which theoretically allowed policy makers to disguise unwanted evidence (cf. Krott, 2012). However such absence of evidence was generally challenged in parliament and arguments based on assumptions did not succeed in discourse. A prominent example in this respect was the rejection of management standards in $\S 11$, BWaldG. In addition to that observation, policy-makers actively addressed the problem of incomplete information by extending the NFI mandate. As a result, since 2012, the new NFI has closed many of those data gaps that I identified within the political discourse. It now includes additional variables on short-rotation plantation, protective forests and on the status of good practice in forest management. By extending the mandate with scientific information, policy-makers also 
showed intentions to remove the risk of bias and of statistical uncertainties. The parliament has thus contributed towards a better knowledge-base for future decisions. 


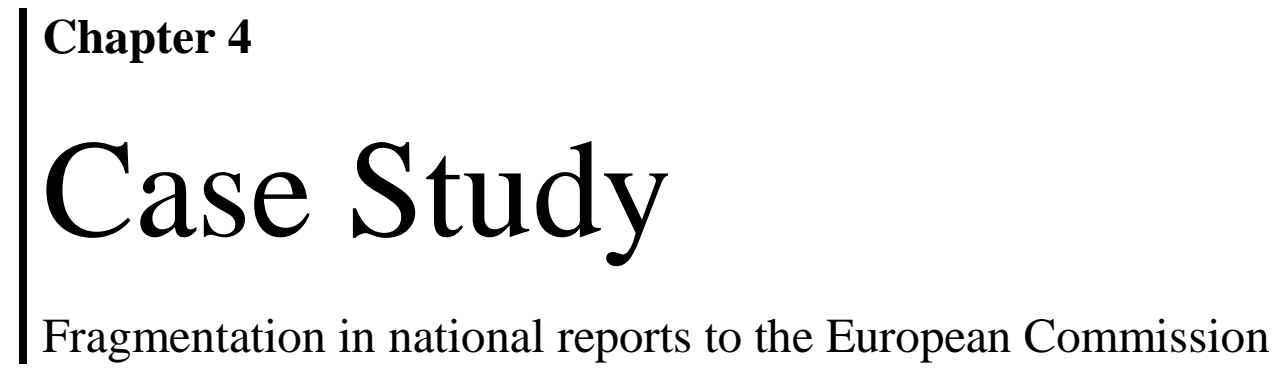




\subsection{Review of rationale and objective}

This thesis' ambition was to contribute knowledge to two research questions. They are summarised by Table 17 as:

Q1: Relevance: What are the attributes, data quality characteristics and providers required in national monitoring and reporting processes to the European Commission?

Q2: Risk of political bias: Is there a risk of political interests to bias, i.e. influence results towards a politically favoured outcome?

The objective of the first question was to shed light on the political relevance of data assessed in forest monitoring programmes (cf. Table 17, column Q1). The previous Chapter no. 3 already made such observations for the parliamentary discourse. It showed that policy makers considered the NFI a very important source of information. This was also reflected by the parliamentary decision to amend legal section $\S 41 \mathrm{a}$ which extended the NFI mandate towards reporting commitments on biodiversity under Habitats Directive (Council Directive 92/43/EEC). In the present chapter, I now want to identify the specific data requirements defined by that policy and investigate in the relative contribution of NFIs as compared to other forest monitoring programmes in Germany and Sweden.

As shown in Table 17, Column Q1 three sub-questions are interesting when we look at data relevance:

(1) Attributes: What are the names and definitions of politically required attributes?

(2) Quality: What is the data quality of the provided measurements?

(3) Providers: Who are the responsible data providers?

These questions are essential to better understand the current value and contribution of forest inventory data towards international reporting processes and to possibly identify options to adjust inventory designs such that the results serve more specifically as input to these reporting requirements. This is important considering the fact that data used for reporting obligations to the European Commission is not only relevant to assess and enforce compliance with the legally-binding obligations under Habitats Directive, but also to justify political action for "sustainable forest management" at the national (cf. Chapter 1 Topic: "good practice in forest management" and BWaldG § 11) and global levels (cf. Chapter 3 CBD- 
Aichi Target 5 "Reducing loss of natural habitats and forest areas", CBD-Aichi Target 7 "Sustainable forest management").

Table 17. Research questions to be answered this thesis (the part to be analysed in this chapter is highlighted by bold frame)

\begin{tabular}{|c|c|c|c|c|c|}
\hline & & Case study & Q 1 Relevance & $\begin{array}{l}\text { Q } 2 \text { Risk of political bias } \\
\text { (confirmed under } 2 \\
\text { conditions) }\end{array}$ & \\
\hline $\begin{array}{l}\text { Interpretation } \\
\text { and decision- } \\
\text { making }\end{array}$ & National & German parliament & $\begin{array}{l}\text { 1. Attributes } \\
\text { 2. Quality } \\
\text { 3. Providers }\end{array}$ & $\begin{array}{l}\text { 1. Political motivation } \\
\text { 2. Non-transparency }\end{array}$ & Chapter 3 \\
\hline \multirow[t]{3}{*}{$\begin{array}{l}\text { Monitoring and } \\
\text { reporting }\end{array}$} & National & $\begin{array}{l}\text { Article } 17 \text { Habitats } \\
\text { Directive } \\
\text { (reports by SE, DE) }\end{array}$ & $\begin{array}{l}\text { 1. Attributes } \\
\text { 2. Quality } \\
\text { 3. Providers }\end{array}$ & $\begin{array}{l}\text { 1. Political motivation } \\
\text { 2. Non-transparency }\end{array}$ & Chapter 4 \\
\hline & Europe & $\begin{array}{l}\text { UN-CBD } \\
\text { (report by EC) }\end{array}$ & $\begin{array}{l}\text { 1. Attributes } \\
\text { 2. Quality } \\
\text { 3. Providers }\end{array}$ & $\begin{array}{l}\text { 1. Political motivation } \\
\text { 2. Non-transparency }\end{array}$ & Chapter 5 \\
\hline & Global & $\begin{array}{l}\text { UN-CBD } \\
\text { (report by UN) }\end{array}$ & $\begin{array}{l}\text { 1. Attributes } \\
\text { 2. Quality } \\
\text { 3. Providers }\end{array}$ & $\begin{array}{l}\text { 1. Political motivation } \\
\text { 2. Non-transparency }\end{array}$ & \\
\hline
\end{tabular}

Table 17 also shows the second objective (cf. Table 17, column Q2). It was to make scientists aware of the risk of political bias within forest information. According to the political theory (Krott, 2012; Krott et al., 2014; Pregernig, 2007; Hertin et al., 2009; Haas, 2004; Pielke, 2007) that I presented previously in Section 3 of Chapter 1, such risk may evolve from the political intention to support interests and agendas by intentionally manipulating forest data towards a politically favoured result. In that theory, lack of transparency in acquisition methods was hypothesized to be a potential tool of disguising or manipulating unwanted evidence (Krott, 2012). Table 17 shows that the second research objective was to verify that theory by analysing 2 conditions: "political motivations" and "lack of transparency". In combination, the analysis of the two conditions may demonstrate if political motivations exist and if non-transparent assessment methods may possibly provide options for reporting authorities to influence assessment results or their reporting towards a politically favoured result. 


\subsection{Materials and methods}

\subsubsection{Analysis of data relevance}

As research question 1 indicated, I differentiated three components that may be relevant to policy-makers: (1) the attribute of a variable, (2) data quality and (3) providers. Now I will describe how I have assessed each of the three components. In that description, the reader may refer to Table 18. It is meant to illustrate the background materials and methods to be consulted in each of the three successive analytical steps.

Table 18. Materials and methods for analysis of research Question 1 ("Relevance"): What are the attributes, data quality characteristics and providers required in national monitoring and reporting processes to the European Commission?

\begin{tabular}{|c|c|c|c|}
\hline $\begin{array}{l}\text { Analysis of requirements } \\
\text { (by } 3 \text { components) }\end{array}$ & EU & National & Materials and Methods \\
\hline 1) Attributes & $x$ & & Obligatory data cells to be filled-out \\
\hline 2) Quality & & $\begin{array}{l}\mathrm{x} \\
\mathrm{x} \\
\mathrm{x} \\
\mathrm{x}\end{array}$ & $\begin{array}{l}\text { 1. Precision levels of reported results } \\
\text { 2. Analysis algorithms } \\
\text { 3. Sampling- and plot design } \\
\text { 4. Measurement methods }\end{array}$ \\
\hline 3) Providers & & $\begin{array}{l}\mathrm{x} \\
\mathrm{x} \\
\mathrm{x}\end{array}$ & $\begin{array}{l}\text { 1. Responsibilities regarding report } \\
\text { compilation } \\
\text { 2. Responsibilities regarding analysis } \\
\text { 3. Responsibilities regarding measurement }\end{array}$ \\
\hline
\end{tabular}

1) As shown in Table 18, analysis of politically required attributes based on the general assumption that all data defined within reporting guidelines (Evans et al., 2011, European Commission DG Env., 2013, European Commission, 2011) was politically relevant. I thus identified politically required attributes by their definitions within the EU-reporting form and quantified them by the cells to be filled out in the report (Table 18). It is important to note that these requirements were formulated at the European level, whereas quality criteria and providers were defined by national authorities (cf. Table 18).

2) Analysis of quality requirements will show that European definitions of quality standards, measurement and assessment methods were not always very specific. Instead, they allowed reporting authorities, i.e. the member states and their ministries, to define own requirements and standards. I therefore identify quality requirements 
from the providers' perspective at the national level. In that analysis, I understand data quality in a wider and more general sense than in the statistical meaning of "accuracy" and "precision". As shown in Table 18, Column 3, Points 2-4, quality characteristics could be measures of precision and accuracy, but they could also comprise other characteristics such as the measurement methods, sampling- and plot design and analysis algorithms. I identify and quantify the relevance of such characteristics by analysing values provided and published within national reports. Any value that national authorities measured or assessed by a specific technique increased the relative importance of that specific technique. For instance, if most of the variables were measured by remote sensing in a specific spatial resolution, then we may infer that reporting authorities accepted this specific resolution as acceptable or sufficient for that specific purpose of policy reporting. Remote sensing and the resolution used for a reporting purpose are then assumed to be "relevant" data quality criteria for the reporting authorities. It is to note, however, that reporting authorities might, in fact, favour higher quality data (e.g. remotely sensed images acquired at higher spatial resolution) but such preferred information was actually unavailable, difficult or impossible to measure. Then, data usage did not reflect the true data requirements and preferences but usage rather reflected a compromise between availability and requirements. Such "true" requirements are, however, difficult to elicit from national reports. Only where reporting authorities discussed the pros and cons of potential data sources and made such information publicly available, I was able to derive such "true" requirements. I will therefore complement my analysis by discussing such requirements whenever possible.

3) As shown above in Table 18, Column 1, the third component of requirements to be analysed in this study are the data providers. Reporting authorities, i.e. the national ministries, usually have a choice between different data providers, may it be universities, governmental research institutes or ENGOs (Environmental NonGovernmental Organisations). My analysis assessed which of them was the most trusted, i.e. most frequently consulted provider. Providers were assumed to be politically relevant when they contributed to the data acquisition process, be it by means of involvement in measurements, analyses or reporting (Table 18, Column 3 , Points 1-3). 
In order to acquire the relevant materials and documents about national data providers and their inventory methods, I made a guided literature research. As already mentioned in this thesis' methods (Ch. 2.2.1), the literature research started with the national report as a key source (cf. Annex V). This key document provided references to other sources such as reports of the monitoring authorities and their web-pages which then provided more information on monitoring guidelines, data compilation algorithms and field manuals. Most of such documents were available via the European Environment Agency's Reporting Obligations Database (EEA ROD, 2015). The database is a platform for data exchange between EEA and member states of a specific reporting obligation. Upload is restricted to reporting authorities and therefore guarantees authenticity and timeliness of background materials. In case of restricted access to the database, I acquired the materials directly from the responsible reporting authorities, their webpages, conference papers, project reports and publications (cf. Annex V).

Unstructured, non-quantitative face- to face interviews or telephone calls with the responsible authorities eventually helped to validate results. These interviews were non-directive interviews, which is a form of unstructured interviews, where the aim is not to acquire quantitative data using a pre-defined set of questions. Instead, by means of flexible questions that adapt to the situation, non-directive interviews generally aim to generate in-depth information on sensitive topics or on topics that are not yet well known (Jamshed, 2014; Gill et al., 2008). Non-response to interview questions did not occur in this flexible approach.

The method was useful for this study, as the complex reporting processes under Habitats Directive and the type of data compiled during closed-door reporting conferences was not readily available. Such information was more easily acquired by a flexible talk with open questions that allowed the interviewee to develop his ideas.

It might be criticised, that such a qualitative method of interviewing is prone to generate incomparable results. Yet it was not necessary to generate unbiased and comparable data at that stage of interview. Instead, comparability of my results was ensured by a structured and comparable analysis of standardised reporting formats (How many cells to be filled out in the report were measured by what kind of methods). The purpose of subsequent interviews was only to validate the accuracy of my conclusions or to acquire access to unpublished documents and reporting documents (e.g. reporting formats, algorithms, manuals, data sources or inventories used in reporting). 
It was further decided to keep the names of interviewees anonymous to protect their identity and to allow them to develop their ideas on sensible issues more openly during the interview. This idea follows observations of social research methods summarised by Opdenakker (2006) who mentioned positive effects of anonymity in interview techniques. For similar reasons, protecting the identity of interviewees is a common method in political science where well known authors and even editors often do not mention names but only refer to their institutional affiliation (cf. Böcher and Krott, 2010). In the present study however, respondents usually provided documents and references, or such references were available via the online reporting obligations database (https://rod.eionet.europa.eu). In such cases, the published documents were always the primary source of analysis. These allowed referencing according to the established scientific standards.

When analysing and evaluating the content of such documents, it is to note however that this requires specific language skills. Official documents, such as field-manuals, guidelines, reports and laws regulating national administrative processes are usually written in national language. Germany and Sweden both provided reporting manuals, guidelines and policy documents in English or German language. It was therefore possible to get a good understanding of administrational processes within these two countries. Among the many signatories of the Habitats Directive, they were thus chosen as case studies to illustrate national biodiversity reporting processes in Europe. I could not pursue a similar analysis for Poland because it provided information on administrative processes such as monitoring guidelines and manuals only in national language. Thus, initially, I had to give up the Polish case study when analysing national reporting processes under EC as described in the chapter at hand. However, in Chapter 5, it was possible to take up analysis again because reporting processes under UN were conducted by EC who provided relevant documents in English language, also for Poland. Any remaining documents from Poland, as relevant for Chapter 5, required only minimal translations which were possible to do using a dictionary.

\subsubsection{Analysing risk of political bias and the (non-) transparency of data}

The chapter on political backgrounds (Ch. 1.2-1.3) has already explained that gaps in transparency could be perceived a political tool for disguising or manipulating unwanted information in purpose of supporting a political argument or benefit. The second objective of this work was to validate that assumption. 
In that endeavour, my analysis seeks to verify the individual arguments of the described political theory (cf. Ch. 1.2 and Krott, 2010, Krott, 2012, Pregernig, 2007, Hertin et al., 2009, Haas, 2004, Pielke, 2007) in a two-step approach $\left(1^{\text {st }}\right.$ "Motivation" and $2^{\text {nd }}$ "Nontransparency" in Table 17): First, the theory assumes that in reporting processes, data selection is motivated by political interests, rather than by a rational motivation to provide science-based evidence. Validating that assumption, I identify political and science-based motivations of actors involved in data acquisition. These motivations comprise responsibilities and interests that could come into conflict with scientific and transparent information acquisition. Second, the same theory assumes that gaps in transparency are a tool to politically bias results. Therefore, in a second step, I evaluate the extent to which nontransparent assessment methods actually allow political interests to influence results. Nontransparent assessment rules for instance, may follow a political interest to disguise unwanted evidence and, in a worst case scenario, non-transparent rules may even hide evidence of political manipulation. In the assessment, methods are assumed to be transparent, when the sampling- and plot design, the measurement methods, indicator thresholds and analysis algorithms are defined unambiguously and clearly. They are therefore reproducible and verifiable by any other interested person. Conversely, data used within national reports is assumed to be non-transparent when rules are defined vaguely. Vague rules include for instance sampling designs that do not define the exact location and size of a sample plot. Vague rules also include measurements of variables without a definition of scale or indicators that do not have a threshold value to indicate the achievement of the measurement target. In such cases, different interpretations were theoretically possible. There was thus a risk for results to differ, based on factors such as training and experience. But most importantly, from the perspective of political theory described in Chapters 1.2 and 1.3, vague rules might also provide options for stakeholders to select those sample locations, scales or threshold values that provided politically preferred results.

\subsection{Results on Attributes (Q1 "Relevance")}

The following section presents results on attributes that are required by reporting guidelines of the European Commission using the example of the Habitats Directive. Article 17 of the Habitats Directive (1992) required these attribute to be measured on all areas that classify as a specific habitat type under Annex I of the Directive. Different reports then compile results by each of the individual habitat types and by the so-called "biogeographical regions" (defined in Germany as: the "Atlantic", the "Continental", and the "Alpine"; respectively defined in 
Sweden as the "Continental", the "Boreal" and the "Alpine", see for illustration Figure 7). As every member state has a different share of habitats and regions, the number of reports may differ accordingly. Thus, in Germany each attribute must be reported 33 times and Sweden compiles 35 reports.

Table 19 provides an overview of the 17 individual attributes that are required for each of these reports. Table 19 also shows how these attributes are compiled and evaluated to make a conservation status assessment. Accordingly, the assessment follows a hierarchy where numeric values are the basis for estimation of an overall conversation status index. As shown in Table 19 under the IDs 2-5, that index is compiled by another 4 indexes describing, the quality of conservation status of (1) habitat area, (2) habitat range, (3) specific structures and functions and (4) future prospects as either "favourable", "inadequate", "bad" or "unknown". However, EU regulations regarding assessment of the 17 attributes and statistical precision levels were generally vague. Neither sampling intensity, nor analysis algorithms or field measurements were defined precisely. Rather than a transparent description of inventory and assessment rules, the EU provided merely a set of guidelines, which allowed member states to define and select country-specific field measurements and analysis algorithms. In Table 19, grey shades indicate were vague assessment rules allowed reporting authorities, i.e. the national ministries, to define own assessment methods.

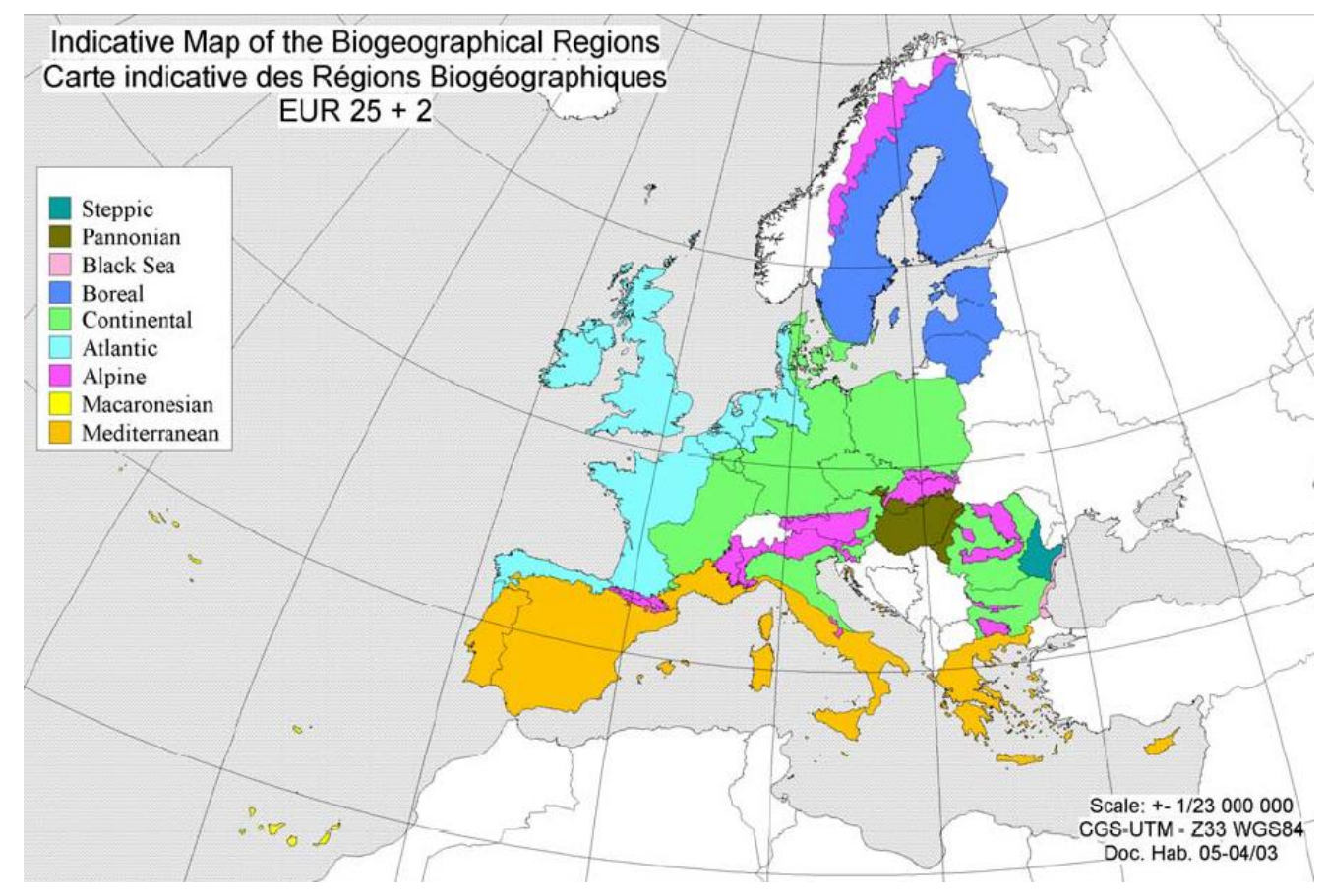

Figure 7. The European Map of Biogeographical Regions. The map shows the biogeographical regions adopted by the Habitats Committee in 2005. (source: ETC/BD, 2006) 
Table 19. 17 Attributes required by EU-habitat types and biogeographical region (ID by data-field of report under Habitats Directive Annex D).

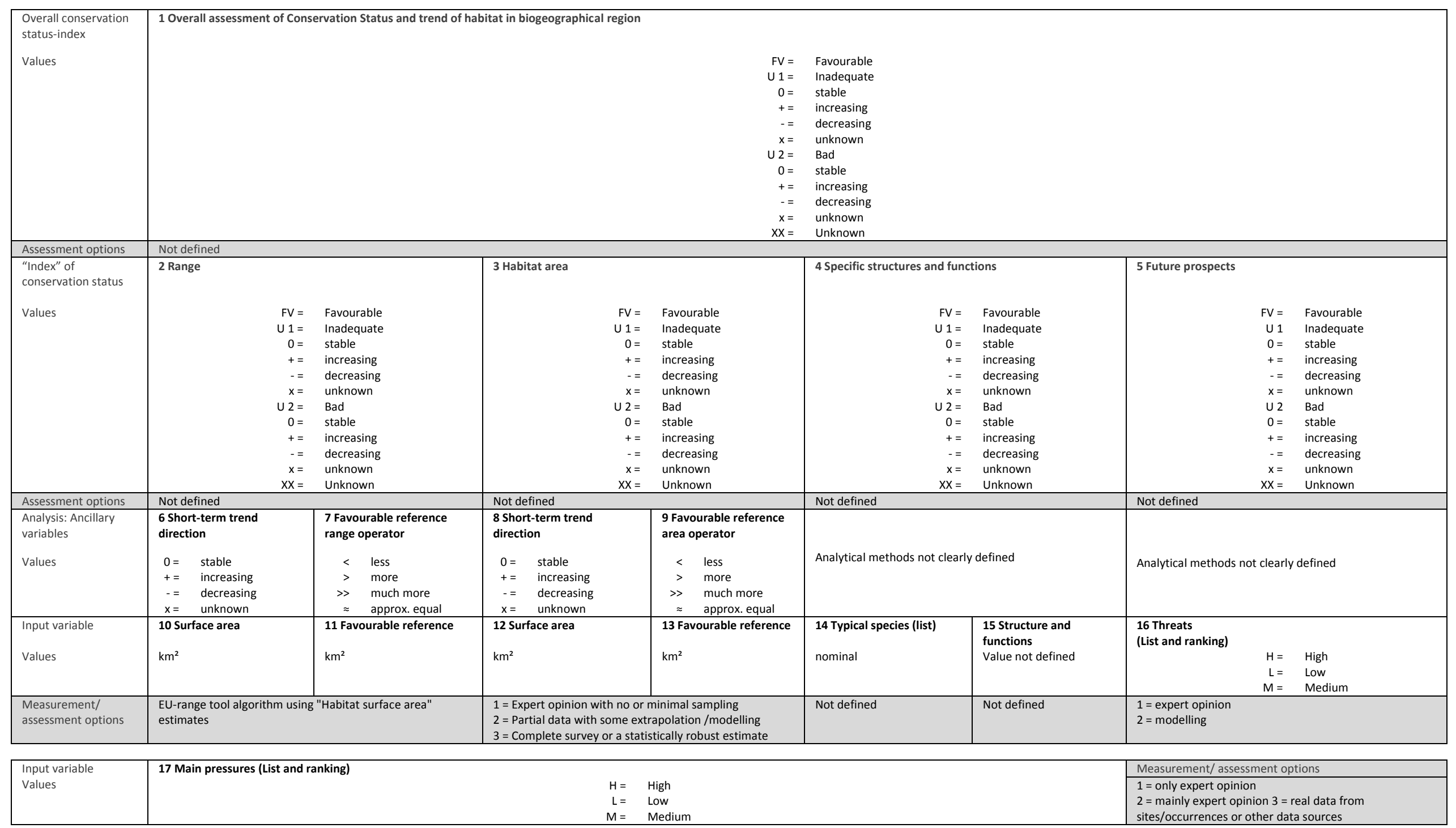




\subsection{Case study: Germany}

\subsubsection{Overview}

In order to identify national quality requirements for the case-study of Germany, the following sections describe my results on the national methods of data measurement and analysis. My method for identification of such national requirements was guided literature research to acquire those data sources and inventories that Germany used in national biodiversity reports. In that approach, I started with the national report as a key source. This key document provided references to other sources such as reports of Federal States and their web-pages which then delivered more information on data providers and their monitoring methods.

In Chapter 4.4.2, I will first present the responsible monitoring and reporting authorities of Germany. In a subsequent Chapter 4.4.3, I describe the national methods that were preferably chosen as an input to the report. In Chapter 4.4.4, a separate analysis of the providers' political motivations and their options to hide or manipulate unwanted evidence will help to evaluate where the German monitoring and reporting process is open to be perceived as politically biased.

\subsubsection{Providers (Q1 "Relevance")}

Table 20 provides an overview of German data providers and reporting authorities to the European Commission: On the top-most level, the Federal Ministry responsible for environment (BMU) compiles the national report. In that process, the Federal Agency for Nature Conservation $(\mathrm{BfN})$ serves as scientific advisor. It translates EU requirements into national monitoring and reporting guidelines. On the next-lower level, departmental research authorities of Federal States, such as the Bavarian Environment Agency (LfU), LowerSaxony's Environment Agency (NLWKN) and other government agencies coordinate monitoring programmes at the State-level (Länder-Ebene). On the lowest level of administration, the individual forest management concession, different authorities execute the field measurements ${ }^{16}$, often depending on forest ownership structure (Table 20, "forest

\footnotetext{
${ }^{16}$ Sample selection and the identification of "habitats" (protected under Habitats Directive) can happen in the framework of different programs and under authority of different administrative bodies. One example is the procedure of urban development plans (Bauleitplanung § 1 BauGB), which identifies and maps sites for construction works. The procedure also requires in the identification of valuable habitats and "compensation"
} 
owners"): In private forests, the EU habitats are usually "measured" by the states' economic chambers for agriculture (Landwirtschaftskammern) or by the States' conservation agencies (mainly biotope mapping programmes on protected areas and other selected sites), public forests under ownership of the German Federation were inventoried by the Institute for Federal Real Estate (Bundesanstalt für Immobilienaufgaben, BImA) or the German armed forces (Bundeswehr), and public forests under ownership of the Federal States are part of the stand inventory of the respective forest agencies. Monitoring of communal forests is responsibility of communal forest administrations which often contract private consultancies for that purpose.

After the amendment of section $\S 41 \mathrm{a}$, federal forest act, another ministry and thus another discipline of forest research is involved in the data acquisition process. The ministry responsible for agriculture and forestry (BMEL) compiles the national report in cooperation with the ministry responsible for environment (BMU). BMEL oversees departmental forestry research of the Thünen Institute (TI), the research authority for designing and planning the national forest inventory (NFI) programme. It translates a range of forest-policy related data needs into variables, assessment methods and algorithms. In cooperation with federal states, the Institute also coordinates the field work and the training of field teams (VwV-BWI II Drs. $52 / 00)$.

Eventually since the extension of the monitoring mandate, two different disciplines are involved in monitoring and reporting: (1) environmental conservation and (2) forestry (Table 20). Though both disciplines are principally necessary and useful for biodiversity monitoring, the sectoral monitoring and reporting authorities under BMU and BMEL seem to cooperate mainly in the process of report compilation and to some, but lesser extent, in the design and execution of inventory programmes. Each branch rather oversees own programmes and there is no nationally and institutionally harmonised set of variables and methods. Yet, the report compilation process itself is cooperative: It involved conferences with both ministries of both disciplines: Environment and Forestry (Table 20).

(Ausgleich) or "substitution" (Ersatz) for any environmental damage (§ 1a Abs. 3 BauGB, §§ 14-15 BNatSchG, Article 6 (2-4) Habitats Directive). In such cases and due to the "polluter pays principle" ( $\$ 15$ BNatSchG) economic stakeholders, i.e. "intervening parties" are usually billed for so-called "environmental assessments" ( $\$ 2$ Abs. 4 BauGB) which includes the abovementioned inventory of habitats. Local administrative bodies are also involved, but only as a supervisor (§ 4c, BNatSchG). 
Table 20. Data providers involved in Germany's national data-acquisition process when reporting to the EC.

\begin{tabular}{|c|c|c|c|}
\hline Providers' discipline & $\begin{array}{l}\text { Environmental } \\
\text { conservation }\end{array}$ & Forestry & \\
\hline $\begin{array}{l}\text { Report } \\
\text { compilation }\end{array}$ & $\begin{array}{l}\text { Ministry } \\
\text { (BMU) }\end{array}$ & $\begin{array}{l}\text { Ministry } \\
\text { (BMEL) }\end{array}$ & Policy \\
\hline Inventory Guidelines & $\begin{array}{l}\text { Federal Agency } \\
\text { (BfN) }\end{array}$ & $\mathrm{TI}$ & Science \\
\hline $\begin{array}{l}\text { Inventory methods } \\
\text { and data analysis }\end{array}$ & $\begin{array}{l}\text { States' } \\
\text { agencies }\end{array}$ & $\mathrm{TI}$ & \\
\hline Measurement & $\begin{array}{l}\text { Various, often } \\
\text { forest owners }\end{array}$ & $\begin{array}{l}\text { States' } \\
\text { agencies }\end{array}$ & \\
\hline
\end{tabular}

\subsubsection{Quality requirements (Q1 "Relevance")}

\subsubsection{Overview}

Having answered research question 1 by a description of relevant attributes and data providers, the following sections (Ch. 4.4.3.2 - 4.4.3.4) explain the quality characteristics, i.e. the statistical measures of uncertainty, the measurement and assessment methods that were regarded relevant by the national reporting authorities. In order to characterise these requirements, I identified the sources and methods of the national monitoring and reporting process by guided literature research. In that approach the national report is used as a key document and references provided within that documents directed me towards field protocols and analysis algorithms that are regarded relevant by German reporting authorities.

The following sections, I present each individual empty data-cell that member states must fill out and report to the European Commission. I further explain the respective methods of measurement and assessment, and I describe the attained quality characteristics. That approach shall allow conclusions on quality preferences of German reporting authorities.

\subsubsection{Reporting "Habitat area" and "Range"}

"Areas" and "Ranges" of habitat types are two important variables that contribute to conservation status assessments and reporting. Areas measure the spatial extent of habitats and range-calculations use the area assessments as an input to calculate the potential spatial extend of habitat areas. The German algorithm based on the EU-range tool (Mac Sharry, 
2012, Urda and Maxim, 2012a, b) and computes the potential future distribution of habitat types. Member states define the input parameters, depending on the national expectations of where habitats could spread and grow in future. In effect, different member states of the EU may come to different range calculations and incomparable results.

It is worth to note that within Germany, different Federal States contributed area assessments to the national sum. Every Federal State has a very complex system of variables, measurement methods and state-specific habitat type classification keys to identify habitat types. It was beyond the scope of this thesis to comprehensively analyse all variables and measurement methods that were used for identifying and reporting the conservation status of "areas" and "ranges" of 33 European forest habitat types within each of the 17 different Federal States of Germany. Therefore, as shown in Table 21, my analysis included only those State-programmes that contributed most to the overall national sum. To quantify this contribution, I consulted 2007 reports from the previous reporting round (cf. Sachteleben and Behrens, 2010a). The results show that due to Bavaria's large share of the total national habitat areas, my approach resulted in an overrepresentation of the Bavarian programme. This means that I analysed mostly those variables reported by the Bavarian programme $(n=18)$ and only few from the other States (reported values by States'-code: NI= 10, MV=2, BW =1, $\mathrm{BB}=1, \mathrm{ST}=1$ ) (refer also to Table 21). In addition, the study may not reflect quality standards of inventory programmes with a smaller coverage of habitat areas and a smaller contribution to the national estimate.

For the Federal States with a larger coverage of habitat types, Table 21 further shows results on relevance of transparent assessment methods. That relevance is evaluated by the respective field protocols and it is quantified by the number of habitat area indicators that were measured by transparent rules. As a result, most of the non-transparent area indicators were found in reports on "Atlantic" habitat types. An example was Lower Saxony's assessment of habitat type 9160 "Sub-Atlantic oak-hornbeam forests" (Table 21). The programe included vague definitions of area-indicators such as "dry to boggy", "half-boggy", "alkaline-rich", "medium alkaline levels", "very nutritious" and "moderate nutritious". In these defintions, precise measurements and threshold values remained obscure, because the qualitative descriptions were not always linked to references that allows precise quantification. As an example, there was an attempt to specify and quantify soil characterisitcs by indicator species. Yet the problem with such indicators was that relevant lists of species were often incomplete and thresholds vague. Thus, a threshold defined as "low proportion of moisture indicator species" 
is imprecise because it neither specifies the proportions, nor the species. Another example for ambiguous area assessments are those for "Wooded dunes in coastal areas" (2180) in Lower Saxony. Here, the protocol did not define precise distances that differentiate coastal- from inland-dunes. As a result, field teams needed to interpret the ambiguous rules and make independent choices of how to measure and assess the variables. These choices were not documented, meaning that the eventually applied measurement methods were not verifiable.

The Bavarian programme specified variables and habitat indicators most precisely (Table 21). Most of them included a (1) measureable scale and (2) a threshold value to unambiguously identify a habitat type. Further, the programme largely avoided indistinct expert assessments and analysed spatial data such as aerial- and satellite imagery by semi-automated pixel-based classification methods. These models were validated by standardised ground-based measurements (or ground-truth) to generate habitat maps with known and statistical levels of data quality (methods in: Kleinschmit et al., 2006). This observation indicates that, compared to other states, statistical measures of data quality, verifiability and transparency were most relevant to the Bavarian programme.

Table 22 summarises such data quality requirements in the 33 area assessments of all Federal States. It shows that other than the 18 habitat types assessed by the Bavarian programme, no other State-authority (Landesverwaltung) demanded random sampling or probability based inventory designs. Instead, the primary data sources were the "biotope mapping programs" of conservation agencies, where each State-administration defined separate protocols and methods. In these programmes a common measurement method was aerial Colour Infrared Imagery (Hamburg, Saxony, Saxony-Anhalt, Schleswig-Holstein, Thuringia) or Landsat-7 satellite imagery provided via the CORINE-Landcover-2000 database (all other Federal States) (BfN, 2013, Lang, 2012a). Also land-use- and elevation information from "digital topographic maps" (DTK) at a 1:10,000 scale (e.g. By, MV, ST, NI) contributed to full-cover habitat mapping. These images were typically provided spatially explicit classifications at a resolution of at least $30 \times 30 \mathrm{~m}$ (Landsat 7), whereas NFI was not designed to provide spatially explicit information for mapping small patches of land. In the reporting process, reporting authorities further chose the previous method of remote sensing because they saw advantages in the assessment of rare or linear habitat types which were not sufficiently covered by the NFI sampling grid (Sachteleben and Behrens, 2010a). Due to the observation that all of the 33 habitat area reports were measured using aerial imagery, Table 22 lists the spatial resolution as an important quality criterion in all of the 33 values reported to the EC. 
Table 22 also shows that for 15 area assessments (by habitat and biogeographical region), statistical measures of uncertainty were no relevant quality criterion. One of the reasons is that most State-programmes were unable to comply with rules of probability-based inventories when they produced maps by visual interpretation and expert assessment, rather than by rigorous standards or automated image processing. Another explanation for the absence of statistical estimates of uncertainty is that ground based measurements did not always follow rigorous statistical principles. Instead of using random designs, sites were often surveyed selectively when ENGOs or conservation agencies suspected potential occurrence of habitat types.

Only the 18 habitat assessments of the Bavarian programme were an exception and Table 22 therefore shows different qualities for the respective reports. The reason is that Bavaria harmonised methods with the design of the NFI in 2006 (LWF, 2007, Müller-Kroehling, 2016), including randomised sampling and transparent, i.e. rule-based measurements. The programme thus complied with rules of statistical sampling and allowed statistical estimation of uncertainties. 
Table 21. Transparency of habitat indicator measurements and analysis of state programmes in Germany. The figure quantifies transparency by the number of habitat area indicators that were analysed or measured by non-transparent assessment rules. The contribution to the national algorithm is quantified by coverage of habitat areas within each Federal State as reported in 2007.

\begin{tabular}{|c|c|c|c|c|c|c|}
\hline & Reports & $\begin{array}{l}\text { EU- } \\
\text { Habitat ID }\end{array}$ & $\begin{array}{l}\text { State } \\
(" \text { Land") }\end{array}$ & $\begin{array}{l}\text { Contribution } \\
\text { to national } \\
\text { algorithm in } \\
\%^{2}\end{array}$ & Transparent & $\begin{array}{l}\text { Non- } \\
\text { transparent }\end{array}$ \\
\hline \multirow{10}{*}{ 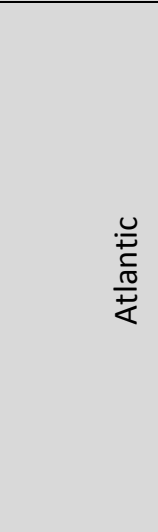 } & 1 & 2180 & $\mathrm{NI}$ & 95,24 & 4 & 16 \\
\hline & 2 & 9110 & $\mathrm{NI}$ & 44,44 & 12 & 9 \\
\hline & 3 & 9130 & $\mathrm{NI}$ & 52,38 & 6 & 10 \\
\hline & 4 & 9150 & $\mathrm{NI}$ & n.d. & 6 & 3 \\
\hline & 5 & 9160 & $\mathrm{NI}$ & 49,21 & 2 & 18 \\
\hline & 6 & 9170 & $\mathrm{NI}$ & n.d. & 8 & 22 \\
\hline & 7 & 9190 & $\mathrm{NI}$ & 46,03 & 9 & 31 \\
\hline & 8 & 91D0 & $\mathrm{NI}$ & 85,71 & 14 & 9 \\
\hline & 9 & $91 \mathrm{E0}$ & $\mathrm{NI}$ & 60,32 & 5 & 8 \\
\hline & 10 & 91F0 & $\mathrm{NI}$ & 54,94 & 3 & 4 \\
\hline \multirow{14}{*}{ 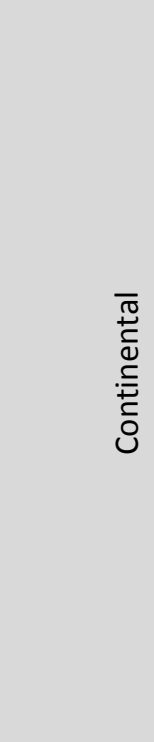 } & 11 & 2180 & MV & 99,49 & 8 & 3 \\
\hline & 12 & 9110 & BY & 18,33 & 34 & 0 \\
\hline & 13 & 9130 & BW & 19,05 & 5 & 6 \\
\hline & 14 & 9140 & BY & 57,14 & 22 & 0 \\
\hline & 15 & 9150 & BY & 26,98 & 20 & 0 \\
\hline & 16 & 9160 & BY & 15,87 & 42 & 0 \\
\hline & 17 & 9170 & BY & 30,16 & 31 & 0 \\
\hline & 18 & 9180 & BY & 30,16 & 24 & 0 \\
\hline & 19 & 9190 & BB & 41,27 & 6 & 7 \\
\hline & 20 & 91D0 & BY & 26,98 & 21 & 0 \\
\hline & 21 & 91E0 & BY & 25,40 & 35 & 0 \\
\hline & 22 & 91F0 & ST & 38,10 & 19 & 1 \\
\hline & 23 & $91 \mathrm{G} 0$ & MV & 51,90 & 12 & 2 \\
\hline & 24 & 9410 & BY & 36,51 & 42 & 0 \\
\hline & 25 & 9110 & BY & 100 & 34 & 0 \\
\hline & 26 & 9130 & BY & 100 & 42 & 0 \\
\hline & 27 & 9140 & BY & 100 & 22 & 0 \\
\hline & 28 & 9150 & BY & 100 & 19 & 0 \\
\hline 등 & 29 & 9180 & BY & 100 & 31 & 0 \\
\hline & 30 & 91D0 & BY & 100 & 21 & 0 \\
\hline & 31 & 91E0 & BY & 100 & 35 & 0 \\
\hline & 32 & 9410 & BY & 100 & 42 & 0 \\
\hline & 33 & 9420 & BY & 100 & 20 & 0 \\
\hline $\begin{array}{l}{ }^{1}=\text { Land } \text { (Feder } \\
\mathrm{BB}=\text { Brandenb } \\
\mathrm{BW}=\text { Baden } \mathrm{W} \\
\mathrm{BY}=\text { Bavaria } \\
\mathrm{MV}=\text { Mecklen } \\
\mathrm{NI}=\text { Lower Sax } \\
\text { ST = Saxony Ar }\end{array}$ & $\begin{array}{l}\text { al state) } \\
\text { urg } \\
\text { /ürttemberg } \\
\text { burg-West Pon } \\
\text { ony } \\
\text { hhalt }\end{array}$ & nerania & $\begin{array}{l}2= \\
\text { algc } \\
\text { rep } \\
\text { rep }\end{array}$ & $\begin{array}{l}\text { e states' percenta } \\
\text { thm was estimate } \\
\text { ted in the previou } \\
\text { ts published in } 20 \\
\text { no data }\end{array}$ & $\begin{array}{l}\text { ge contribution to } \\
d \text { by coverage of } \\
\text { 7) reporting period }\end{array}$ & $\begin{array}{l}\text { national } \\
\text { abitat types as } \\
\text { (2001-2006, }\end{array}$ \\
\hline
\end{tabular}


Table 22. Relevance of data quality criteria in German reports on the variables "habitat area" and "range" $\left(\mathrm{m}^{2}\right)$ in States' programmes. Data quality criteria were identified by characteristics of inventory methods. Numeric figures show how many of the 33 reported values satisfied the individual data quality requirements.

\begin{tabular}{|c|c|c|c|c|}
\hline \multicolumn{2}{|c|}{ Data quality criteria } & Relevant & Irrelevant & Total \\
\hline \multicolumn{5}{|c|}{ Measurement methods } \\
\hline & 1. Ground-based measurements & 33 & 15 & 33 \\
\hline & 2. Remote Sensing & 33 & 15 & 33 \\
\hline \multicolumn{5}{|c|}{ Statistical and analytical qualities } \\
\hline & 3. Sampling & 18 & 15 & 33 \\
\hline & 4. Spatial resolution of at least $30 \times 30 \mathrm{~m}$ & 33 & 0 & 33 \\
\hline & 5. Statistical measures of precision and accuracy & 18 & 15 & 33 \\
\hline & 6. Transparency & 18 & 15 & 33 \\
\hline
\end{tabular}

\subsubsection{Reporting "Specific structures and functions"}

Having described methods of habitat area-assessments, the following two sections present results on data quality requirements of German authorities involved in the process of monitoring and reporting the variable "forest structures and functions". The variable is an index and built from variables describing physical components of habitat areas (Evans et al., 2011, p.47) such as species composition, forest layers and habitat trees. The data sources of these variables indicated that the qualities of NFI and sample-based inventory designs had been recognized by reporting authorities. Accordingly, since 2013, the NFI is used for monitoring 18 common habitat types, whereas the 15 less common habitat types are assessed by programmes of Federal States and the Federal Republic (BfN).

Table 23 lists the most important qualities of the individual inventory programmes: under Points 1 and 2, Table 23 shows that ground-based measurements and sample size were very important for the reporting authorities. The standards were defined at a 2008 conference of representatives of conservation agencies (LANA), representatives of forest agencies of the Federal States (Forstchefkonferenz), BfN, TI, and BMEL (Meeting on March 2008 in Eltville in: Sachteleben and Behrens, 2010a). In that conference, the authorities accepted the necessity to reduce monitoring effort by sampling and to define a minimum sample size of $n=63$ per habitat type within each of the 3 "biogeographical regions" (Alpine, Continental, Analytic, cf. Ch. 4.3). The NFI satisfied that requirement for 18 forest habitat types, i.e. for 18 reported values. The remainder stayed under responsibility of BfN or conservation agencies of Federal States (Table 23). 
Table 23 also addresses additional quality requirements: while the 18 NFI authorities provided statistical estimates of precision and accuracy, these estimates were not reported for the 15 assessments of Federal States and the Federal Republic. This is, at least, indicated by an analysis of the inventory methods (Sachteleben and Behrens, 2010a). The Federal- and the States' methods were somewhat comparable to 2-phase sampling: The states reported their habitat area maps to the Federal Republic (BfN), which then randomly selected 63 habitat sites for field assessment. As I have explained in the previous section (Ch. 4.4.3.2), the statistical problem of that method is limited randomization in the initial mapping phase. That problem eventually translated into the next sampling phase. It meant that estimation was not possible and measures of precision may not be derived for the 15 assessments provided by the Federal States.

In these assessments, also the plot design was problematic from a statistical perspective. The designs used neither a fixed plot size (it was adaptive to the shape of habitats), nor statistical rules to establish an adaptive plot-design. Rather, the methods of the Federal Republic and most of the States assumed that field teams inventory the full area of a delineated habitat polygon (Sachteleben and Behrens, 2010a). Yet, from a practical perspective it may remain questionable if the field teams really measured every single component of areas with plot sizes bigger than $0.05 \mathrm{ha}-10 \mathrm{ha}$, in particular in the absence of detailed field protocols that establish a clear procedure of how to do that. The range describes the minimum sizes for the different forest habitat types. If an identified habitat crossed that threshold, then the full area needed to be inventoried. For instance, the Wooded dunes of the Atlantic, Continental and Boreal regions (ID 2180) need to be at least 0.5 ha in area to be inventoried while the naturally bigger Luzulo-Fagetum beech forests (ID 9110) needs to surpass the 10 ha-threshold (cf. Sachteleben and Behrens, 2010a). These plot sizes are generally quite big for an assessment that aims to make a complete assessment of the full plot. There was at least a reasonable risk of smaller areas being inventoried, depending on, for instance, time pressure, motivation or experience. Eventually, the selection methods were prone to the introduction of measurement errors which further complicated the analysis in the 15 assessments provided by the Federal Republic and States.

Table 23 and the more specific descriptions in Table 24 also show that BfN, NFI and State programmes not only differed with regard to sampling design and statistical measures of uncertainty. Also the extent to which they were able to comply with transparent and verifiable assessment rules was different. This conclusion is based on analysis of field protocols and 
reporting guidelines (Sachteleben et al., 2010b). Table 24 presents the more detailed results of that analysis: for that purpose, the table provides an overview of the 33 habitat assessments and shows how many of the individual input variables were measured by non-transparent rules. It shows that, regarding data quality, the NFI and the States' programmes satisfied different expectations with their area assessments: the NFI focussed on transparent assessments and contributed data in the form of verifiable measurements. Examples include "number of canopy classes", "percentage cover of forest development stages", "number of habitat trees", analysis of "volume of dead wood stocks" and observation of types of "canopy cover layers". Federation and most States in contrast needed to accept non-transparent methods and used expert opinion to assess variables such as "geological relief or floodplain structures" by arbitrary threshold values and categories such as "very well-", "well-" and "moderately developed". These definitions neither included a measurement scale, nor a precise threshold that supported classification to make it better re-producible. The measurement was therefore difficult to operationalise and the decision of the reported value was most likely to be unverifiable, i.e. an expert decision.

Table 23. Relevance of data quality criteria in German reports on the variable "Specific structures and functions" (index). Data quality criteria were identified by characteristics of inventory methods. Under the headline "relevant", numeric figures shows how many of the 33 reported values satisfied the individual data quality requirements.

\begin{tabular}{|c|c|c|c|c|}
\hline Data sources & Data quality criteria & Relevant & Irrelevant & Total \\
\hline \multicolumn{5}{|c|}{ TI and LWF (NFI) } \\
\hline & $\begin{array}{l}\text { 1. Ground-based measurement } \\
\text { 2. Sample size (at least 63) } \\
\text { 3. Statistical measures of precision and accuracy } \\
\text { 4. Transparency of methods }\end{array}$ & $\begin{array}{l}18 \\
18 \\
18 \\
18\end{array}$ & $\begin{array}{l}0 \\
0 \\
0 \\
0\end{array}$ & $\begin{array}{l}18 \\
18 \\
18 \\
18\end{array}$ \\
\hline \multicolumn{5}{|c|}{ BfN and most of the States' agencies (sample) } \\
\hline & $\begin{array}{l}\text { 1. Remote-sensing and ground-based } \\
\text { measurement } \\
\text { 2. Sample size (at least } 63 \text { ) } \\
\text { 3. Statistical measures of precision and accuracy } \\
\text { 4. Transparency of methods } \\
\text { 5. Spatial resolution at least } 30 \times 30 \mathrm{~m}\end{array}$ & $\begin{array}{r}15 \\
15 \\
0 \\
0 \\
15\end{array}$ & $\begin{array}{r}0 \\
0 \\
0 \\
15 \\
15 \\
0\end{array}$ & $\begin{array}{l}15 \\
15 \\
15 \\
15 \\
15\end{array}$ \\
\hline
\end{tabular}


Table 24. Precision requirements and transparency of methods in German reports on the variable "Specific structures and functions" (index). The table quantifies transparency/non-transparency by the number of variables that were analysed or measured by non-transparent observation protocols.

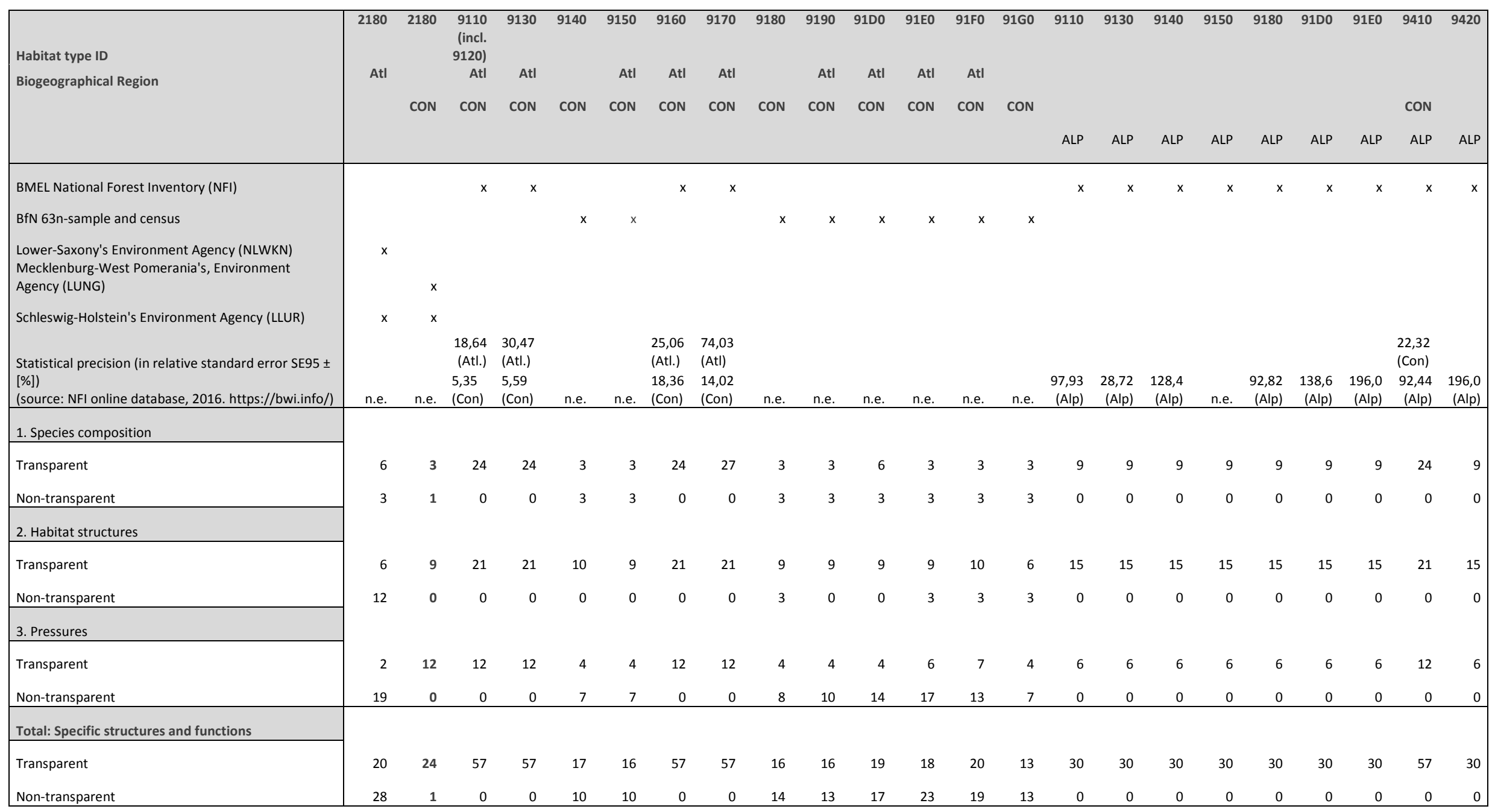




\subsubsection{Reporting the "Conservation status"-indexes}

Besides quantitative measurements of areas and structural components, for each of the 33 habitat types, the European report also required a qualitative assessment of "conservation status" for the variables "area", "range", "future prospects" and "structures and functions". "Conservation status" is an index compiled by the previously described input data and it is classified from "favourable" to "unfavourable / bad". This section describes the inventory programmes and their relevant quality characteristics.

Results of Table 25 indicated that transparency of assessments to the general public could not always be achieved. Evidence for that is that the compilation of the conservation status indexes and the final decision on their values was made by internal conferences with representatives of Federation and States. These were closed to the public and did not reveal any information on which basis the individual decisions had been made. Eventually, the NFI might be relevant only as a source of background information that is amendable by a committee decision.

In effect, NFI results may vary from the submitted report (Kroiher et al., 2017). An example for deviation of NFI and report results is the assessment of conservation status-index of structures and functions in continental Luzulo-Fagetum beech forests (Habitat ID 9110). NFI assessed conservation status as "unfavourable-bad" (NFI code C) on $4.36 \%$ of the habitat's areas, $77.74 \%$ was categorised "unfavourable-inadequate" (NFI Code B). Only $17.89 \%$ achieved a favourable status (NFI code A) (NFI database: TI, 2014). According to the "Pinneberg-Scheme", a rule based algorithm developed for summing up three different conservation status-classifications (cf. LANA, 2001; Kroiher, 2017), the assessment should had become "unfavourable-inadequate". The official report to the Commission however graded the total area as "favourable" (BfN, 2013a). It might be possible that there were good reasons for making that assessment, yet the background for that decision remain unknown to external researchers. Also the importance of other available information sources such as sample based inventories and their influence on the committee's decisions remain difficult to quantify. For these reasons, Table 25 shows a low grading of relevance for the quality criteria: "transparency" and "statistical measures of uncertainty" in all of the 33 assessments of conservation status. 
Table 25. Relevance of data quality criteria in German reports on the variable "conservation status" (index). Data quality criteria were identified by characteristics of inventory methods used in the monitoring and reporting process. Under the headline "relevant", numeric figures shows how many of the 33 reported values satisfied the individual data quality requirements.

\begin{tabular}{|l|l|r|r|r|}
\hline Data sources & Data quality criteria & Relevant $^{1}$ & Irrelevant & Total \\
\hline \multicolumn{2}{|l|}{ Federation and States' Conferences (decision of committee) } & 0 & 33 & 33 \\
\hline & $\begin{array}{l}\text { 1. Statistical measures of precision and } \\
\quad \begin{array}{l}\text { accuracy } \\
\text { 2. Transparency of methods }\end{array}\end{array}$ & 0 & 33 & 33 \\
\hline
\end{tabular}

A data quality criterion was assumed to be "relevant", when providing authorities decided to use information with such characteristics. Numeric figures show how many of the 33 reported values satisfied the individual data characteristics. Data quality criteria were assumed to be "irrelevant" to providing authorities when they were not found to be a characteristic of the reported data sources.

\subsubsection{Risk of political bias (Q2)}

\subsubsection{Introduction to the argument}

From a policy-research perspective this work's ambition was to contribute knowledge on the relevance of political motivations in inventory development and to make inventory specialists aware of implications that evolve from political instrumentalisation. For this propose, validation of two conditions shall test political theory (Krott, 2012; Krott et al., 2014; Pregernig, 2007; Hertin et al., 2009; Haas, 2004; Pielke, 2007): (1) political motivations (2) non-transparent characteristics (Table 26). That theory assumes that non-transparent assessment methods allow political motivations to tacitly influence, i.e. bias, assessment outcomes. I will verify that assumption by initially elaborating stakeholder motivations and political interests that could come into conflict with scientific results. I will then discuss if data characteristics really created enabling conditions to produce results that are biased towards stakeholders' motivations and political benefit. Here the objective is neither to claim that results are biased, nor to blame authorities. The evidence is simply not enough to come to such conclusions. Instead, I want to identify shortcomings where the assessments need adjustment if the objective is to avert risks of being (mis-)perceived as politically biased.

\subsubsection{Scientific motivation and benefit of transparency}

In Chapter 4.4.2 we found that two stakeholder groups were involved in reporting (Table 20):

(1) Forestry and (2) Environmental conservation. Chapter 4.4.3 showed that the respective authorities had very different quality requirements: Forestry agencies focussed on statistical 
measures of precision and accuracy. For this purpose, their inventory protocols defined transparent measurement and assessment rules, including automated algorithms, statistical inventory designs and numeric measurement (Table 26). From the mainly science-based research focus, we may infer that data requirements like transparency and statistical measurements followed a motivation to contribute science-based knowledge and to receive credibility within the scientific community. Table 26 summarises this observation and shows that there is no evidence for us to conclude that the Thünen Institute's scientific responsibilities could be in any conflict with opposing political motivations. We may conclude that there is little risk of NFI assessments to be perceived as politically biased.

Table 26. Risk of political bias in German monitoring and reporting programmes under Habitats Directive. The table describes risk of political bias as a function of political motivations and non-transparent assessment methods. Political motivations are confirmed when other of the institutions' duties could come into conflict with monitoring responsibilities. Lack of transparency is quantified by the number of reported values with unverifiable assessment methods.

\begin{tabular}{|c|c|c|c|c|c|c|c|c|c|c|c|}
\hline \multirow{2}{*}{$\frac{n}{\frac{n}{0}}$} & \multirow{2}{*}{$\begin{array}{l}\text { Stakeholder group } \\
\begin{array}{l}\text { Consulted } \\
\text { authorities }\end{array}\end{array}$} & \multicolumn{5}{|c|}{ Environmental conservation } & \multirow{2}{*}{$\begin{array}{l}\begin{array}{l}\text { Forest- } \\
\text { ry }\end{array} \\
\mathrm{TI}^{3}\end{array}$} & \multirow{2}{*}{\multicolumn{4}{|c|}{$\begin{array}{l}\text { Both Environment and Forestry } \\
\text { Conferences of Federation, States } \\
\text { and sectoral (utilitarian and } \\
\text { conservation) agencies (decision o } \\
\text { committee) }\end{array}$}} \\
\hline & & \multicolumn{2}{|c|}{ Federal States ${ }^{1}$} & \multicolumn{3}{|l|}{$\mathrm{BfN}^{2}$} & & & & & \\
\hline \multirow{2}{*}{ 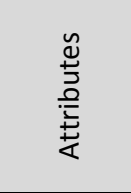 } & \multirow{2}{*}{$\begin{array}{l}\text { Variables and values } \\
\text { to be filled- out in } \\
\text { the report }\end{array}$} & \multicolumn{2}{|c|}{ Habitat area } & \multirow{2}{*}{$\begin{array}{l}\text { Range } \\
\begin{array}{l}\text { Cover } \\
\left(\mathrm{km}^{2}\right)\end{array}\end{array}$} & \multirow[b]{2}{*}{$\begin{array}{l}\text { Trends } \\
(+, 0,-)\end{array}$} & \multicolumn{3}{|c|}{$\begin{array}{l}\text { Specific structures and } \\
\text { functions }\end{array}$} & \multirow{2}{*}{$\begin{array}{l}\text { Habitat } \\
\text { area }\end{array}$} & \multirow{2}{*}{$\begin{array}{l}\text { Range } \\
\text { Status } \\
\text { (index) }\end{array}$} & \multirow{2}{*}{$\begin{array}{l}\text { Future } \\
\text { Pro- } \\
\text { spects } \\
\text { Status } \\
\text { (index) }\end{array}$} \\
\hline & & $\begin{array}{l}\text { Cover } \\
\left(\mathrm{km}^{2}\right)\end{array}$ & $\begin{array}{c}\text { Trends } \\
(+, 0,-)\end{array}$ & & & \begin{tabular}{|l|} 
Status \\
(index)
\end{tabular} & \begin{tabular}{|l} 
Status \\
(index)
\end{tabular} & \begin{tabular}{|l|} 
Status \\
(index)
\end{tabular} & & & \\
\hline \multirow{2}{*}{ 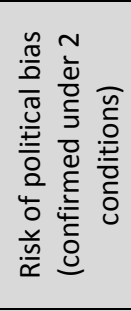 } & $\begin{array}{l}\text { 1. Political } \\
\text { motivation/ conflict } \\
\text { of interest (as a } \\
\text { result of other } \\
\text { responsibilities) } \\
\end{array}$ & $x$ & $x$ & - & - & - & - & - & - & - & \\
\hline & $\begin{array}{l}\text { 2. Lack of } \\
\text { transparency of } \\
\text { methods }\end{array}$ & 15 & 15 & 15 & 15 & 15 & 0 & 33 & 33 & 33 & 33 \\
\hline \multicolumn{2}{|c|}{ Total number of reports } & 33 & 33 & 33 & 33 & & & 33 & 33 & 33 & 33 \\
\hline
\end{tabular}

\subsubsection{Motivations and benefits of lack of transparency}

In terms of the transparency of assessment methods, Table 26 shows a specific situation for data provided by the Federal States' agencies of biodiversity conservation and environment. In 
15 reports, they had to accept non-transparent methods and used expert opinion rather than standardised inventory protocols. The implication was the impossibility to predict uncertainty or to validate data quality in ways that are generally understood to be good practice in statistically-based estimations. Theoretically, there might be two motivations explaining this observation, a scientific and a political one:

1) Firstly, the scientific motivation could be to allow assessment of variables that are difficult to measure by standardised methods. Then, expert opinion had advantages because it thrives on experience which then allows better identification of rare events. Visual assessments further generate a quick overview of the complexity of ecosystems and allow an easy judgement on potential cause-effect relationships. This is an advantage in complex ecosystems, where a statistically sound representation of effects would have been impractical or too costly.

2) From the perspective of political theory (after: Krott, 2012; Krott et al., 2014; Pregernig, 2007; Hertin et al., 2009; Haas, 2004; Pielke, 2007) explained in Chapters 1.2 and 1.3, there is a risk that political motivation might be perceived a more plausible explanation. The reason is that the major monitoring effort, i.e. habitat area mapping, was under authority of stakeholders such as forest owners, landscape planning and land-administrations whose responsibilities could possibly come into conflict with a purely technical and unbiased monitoring process: In fact, sample selection could happen within the framework of landscape-planning and construction works ${ }^{17}$. Here, state administration and economic stakeholders were usually both responsible for the identification of habitat areas and the selection of samples (Dunz, 2005). Conflict of interest existed when measurements confirmed habitat types because evidence generally comes with the legal obligations to protect those identified habitat types, either by measures of "compensation" (Ausgleich) and "substitution" (Ersatz) (Article 6 (2-4) Habitats Directive and $\S 14,15,19$ BNatSchG) or, within 6 years, by decree and designation as "Special Areas of Conservation" (SAC) (Article 4 (4) Habitats Directive) (EC, 2000). These instruments usually imply legally-binding management

\footnotetext{
${ }^{17}$ Sample selection and the identification of "habitats" (protected under Habitats Directive) can happen in the framework of different programs and under authority of different administrative bodies. One example is the procedure of urban development plans (Bauleitplanung $\S 1$ BauGB), which identifies and maps sites for construction works. The procedure also requires in the identification of valuable habitats and "compensation" (Ausgleich) or "substitution" (Ersatz) for any environmental damage (§ 1a Abs. 3 BauGB, §§ 14-15 BNatSchG, Article 6 (2-4) Habitats Directive). In such cases and due to the "polluter pays principle " ( $\$ 15$ BNatSchG) economic stakeholders, i.e. "intervening parties" are usually billed for so-called "environmental assessments" ( $\$ 2$ Abs. 4 BauGB) which includes the abovementioned inventory of habitats. Local administrative bodies are also involved, but only as a supervisor ( $\S 4 \mathrm{c}, \mathrm{BNatSchG}$ ). In practice, this means that the assessment of environmental features usually happens in cooperation of local with intervening parties (cf. Dunz, 2005).
} 
restrictions and, in case of severe limitations, compensation payments could be another consequence. In either way, evidence of habitat types typically results in monetary burden to the forestry sector or those who intent to intervene in the natural system by disturbances such as constructions works, intensive forest management practices and others. From the perspective of forest owners, the option to avoid such costs by hiding unwanted information might possibly seems to be appealing.

The previous analysis on the relevance of "transparency" in national methods of monitoring and reporting found that the theoretical (but unconfirmed) option to hide information potentially existed (summarised in Table 26). Non-transparent assessment rules and limitations in adherence to principles of statistical sampling then created conditions that might possibly allow interests, if they existed, to steer selection of sites. There was thus a potential option to sample only protected areas within the Natura 2000 network or those with little environmental value. In such cases, stakeholders could possibly hide unwanted evidence of new habitat sites that would have come with legally-binding management restrictions. By dismissing those sites, land owners and site administration could eventually enforce the political interest of saving costs that would have resulted from the legal obligation to enforce the protection status and to limit intrusive forestry activities.

In addition to responsibilities of site protection and site management which are more likely to be in conflict with area estimates, another responsibility might be at odds with monitoring obligations: On public forests, Federal States were responsible for both, monitoring and managing of habitat types. That responsibility might be perceived to come into conflict with area estimates and assessment results of conservation status: Under the EU's Common Agricultural Policy (CAP) and the Habitats Directive, occurrence and conservation status of habitat types can steer the distribution of EU-funds. Thus, some areas are more likely to qualify for conservation funds, when they actually include EU habitats (SRU, 2008, Habitats Directive Article 8(4)). Further, in accordance with the legal obligation to avoid deterioration (Article 6.1. Habitats Directive), funds for management plans under Article 8.1 Habitats Directive should specifically target sites with an unfavourable conservation status index. In such cases, as summarised in Table 26, there might be a political motivation to control eligibility for EU-funds or site designations. The previously observed lack of transparency of assessment methods then created conditions that might allow selected stakeholders to manipulate the reporting of results towards these politically favoured outcomes. Yet, the extent to which the forestry sector and stakeholders with utilitarian interest were really 
involved remains unclear. Table 26 therefore illustrates that political motivations are just one of two possible options. Scientific motivations and an honest interest to fill data gaps of difficult to measure variables by expert opinion and a scientifically informed discourse, might equally explain the scientific value of flexible assessment rules.

\subsubsection{The relevance of standardization and NFI}

Having explained possible political benefits of vague assessment rules and expert opinion, a new question emerges: if non-transparent assessment rules were a political benefit, why was the standardized and rule-based design of NFI relevant for the assessment of structures and functions? In fact, the primary advantages of using NFI was to harmonize assessment methods across Germany and to remove monitoring burden from existing habitat monitoring programmes (Sachteleben and Behrens, 2010). Given that NFI's overall contribution to the final report remained very low, technical advantages such as transparency and statistical estimates of data quality seem not to be a major criterion. The NFI provided only background information for most assessments, including species composition, habitat structure and threats. According to the principle of division of powers in a federal system where governments share powers, the final decision on the data to be reported however rested with conferences of Federation and States.

Monitoring politically relevant information, i.e. those that come with monetary implications was not the responsibility of NFI. Area assessments of habitat types for instance lead to the obligation to protect those sites and usually created a monetary burden. These assessments were still responsibility of States and often, the forestry sector. According to Mecklenburg (2005) such involvement of States and potential economic interests could result in conflict of interest. My study has shown that there was a theoretical risk for the vague assessment rules to be skewed or interpreted such as to produce a politically favoured result. This might enforce existing perceptions of political bias and put at risk the credibility of results, even if they were in fact based on all best intentions to produce sound scientific evidence. In fact bias is not the only explanation. Best intentions to produce accurate results might also be a reason for vague assessment rules. Indeed, especially in complex ecosystems that are not completely understood and that may look very different depending on local situations, individual components might be difficult to generalise by standardised inventory rules. In such cases, more general assessment rules and expert assessment provide more flexibility to adapt to the 
given situations and to discover yet unknown but important components of biodiversity that are important for making a holistic assessment.

\subsection{Case study: Sweden}

\subsubsection{Overview}

Also Sweden, same as all other member state of the European Union, has biodiversity reporting obligations under the Habitats Directive. The introductory part of this thesis has already explained that Sweden was selected as a case study because its relatively large share of forest area and its comparably strong research focus on forest inventory indicated a welldeveloped reporting programme that may provide further ideas on how to better adapt other countries' inventory programmes towards political data requirements. For the purpose of identifying inventory and reporting methods in the Swedish case-study, the following sections employ again the method of guided literature research. That method uses the national report as a key-document and references within that document then guided me towards the background methods of measurement and national data analysis. The following sections (Ch. 4.5.2 - 4.5.3) thus extend our previous findings on German data requirements to those of Sweden. As before, I will start by a description of politically required data providers (Ch.4.5.2) and qualities (Ch. 4.5.3). Eventually, in Chapter 4.5.4, a separate analysis will then evaluate the risk of political bias in Swedish monitoring and reporting processes.

\subsubsection{Providers (Q1 "Relevance")}

The following introduces the Swedish monitoring and reporting process by a description of authorities, governmental agencies and scientists involved in that process. Results are presented in Table 27 and they show that the Swedish Environmental Protection Agency was responsible for report compilation and submission. For the purpose of monitoring and measuring biodiversity in forests, the Swedish Environmental Protection Agency mandated the Swedish University of Agricultural Sciences (SLU), with a full range of obligations: The entire process of data acquisition to analysis was a joint effort of two of the university's institutions: it's so-called "Species Information Centre" and the SLU-Department of Forest Resource Management. The latter also designed and oversaw inventories. Both institutes trained the field teams and cross-checked measurements for validity. 
The cooperation showed that the two institutes shared their expertise. The SLU Species Information Centre contributed knowledge on taxonomy and biodiversity conservation, while the SLU-Department of Forest Resource Management added specific expertise on forest management, statistical modelling, remote sensing techniques and long-term experience with forest inventory development. The close cooperation of the institutes allowed integration of knowledge from two disciplines, biodiversity conservation and forestry. It also enabled harmonisation and comparability of results by a single inventory protocol and a scientificallybased data analysis process.

To my knowledge, political stakeholders were not directly involved in the data acquisition process. The university did not cooperate with governmental ministries and political interests had only few options to enter the inventory design process. Policy-makers such as ministries of forestry or environmental conservation could influence inventory development only indirectly via the mandate and research funding. They were thus able to support a specific research objective, but they were not directly involved in the methodology and the result to be reported to the European Commission. The described distribution of responsibilities eventually indicates that scientific, rather than political standards defined the inventory protocol.

Table 27. Data providers involved in Sweden's national data-acquisition process when reporting to the EC.

\begin{tabular}{|c|c|c|c|}
\hline $\begin{array}{l}\text { Providers' } \\
\text { discipline }\end{array}$ & $\begin{array}{l}\text { Biodiversity } \\
\text { conservation }\end{array}$ & Forestry & \\
\hline $\begin{array}{l}\text { Report } \\
\text { compilation }\end{array}$ & $\begin{array}{l}\text { Environment } \\
\text { Agency }\end{array}$ & & Policy \\
\hline $\begin{array}{l}\text { Inventory } \\
\text { Guidelines } \\
\text { Inventory } \\
\text { methods and } \\
\text { data analysis }\end{array}$ & $\begin{array}{l}\text { SLU } \\
\text { Species } \\
\text { Information } \\
\text { Centre }\end{array}$ & $\begin{array}{l}\text { SLU } \\
\text { Department of } \\
\text { Forest } \\
\text { Resource } \\
\text { Management }\end{array}$ & Science \\
\hline Measurement & & & \\
\hline
\end{tabular}




\subsubsection{Quality requirements (Q1 "Relevance")}

\subsubsection{Overview}

The previous section identified data providers that the Swedish ministry regarded relevant for reporting purposes. In order to characterise quality requirements of such providers, I identified the sources and methods of the national monitoring and reporting process by the method of guided literature research. According to methods described in the same Chapter (4.2.1), non-quantitative interviews with the respective reporting authorities then validated results. Table 28 presents an overview of the results. The relevance of each criterion is quantified by the number of reported values that have the criterion as a characteristic. In the following sections (Ch. 4.5.3.2 - 4.5.3.6), I describe the results in more detail and I explain how they have been derived. For this purpose, I present each attribute separately, I describe the particular methods of assessment and measurement and their respective quality characteristics. 
Table 28. Summary of information needs and data quality characteristics in Swedish biodiversity reports under the Habitats Directive. The table summarizes European requirements by attributes to be reported to the European commission. It also shows the 7 quality characteristics deemed relevant by Swedish reporting authorities. Numeric figures show how many of the 34 reported values satisfied the individual data quality requirements and link them to the providing authorities. Empty cells show cases where I could neither confirm nor reject relevance of a data quality criterion.

\begin{tabular}{|c|c|c|c|c|c|c|c|c|c|}
\hline \multirow{4}{*}{\begin{tabular}{|c}
$\frac{n}{0}$ \\
$\frac{0}{0}$ \\
$\frac{0}{2}$ \\
$\frac{0}{2}$
\end{tabular}} & Stakeholder group & \multicolumn{8}{|c|}{ Both Environment and Forestry } \\
\hline & Consulted authorities & \multicolumn{8}{|l|}{$\mathrm{SLU}^{1}$} \\
\hline & \multirow{2}{*}{$\begin{array}{l}\text { Variables and values to be filled out in the } \\
\text { report }\end{array}$} & \multicolumn{2}{|c|}{ Habitat area } & \multicolumn{2}{|l|}{ Range } & \multirow{2}{*}{$\begin{array}{l}\text { Habitat } \\
\text { area }\end{array}$} & \multirow{2}{*}{\multicolumn{2}{|c|}{\begin{tabular}{l|l} 
Range & $S \& F^{3}$ \\
tatus (index)
\end{tabular}}} & \multirow{2}{*}{\begin{tabular}{|l} 
Future \\
Pro- \\
spects \\
\end{tabular}} \\
\hline & & $\begin{array}{l}\text { Cover } \\
\left(\mathrm{km}^{2}\right)\end{array}$ & $\begin{array}{l}\text { Trends } \\
(+, 0,-)\end{array}$ & $\begin{array}{l}\text { Cover } \\
\left(\mathrm{km}^{2}\right)\end{array}$ & $\begin{array}{l}\text { Trends } \\
(+, 0,-)\end{array}$ & & & & \\
\hline \multirow{9}{*}{ 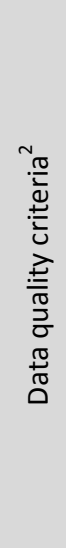 } & \multicolumn{9}{|l|}{ Measurement methods } \\
\hline & 1. Remote sensing at $0.5 \mathrm{~m}$ resolution & 34 & 0 & 34 & 0 & 34 & 34 & - & - \\
\hline & 2. Ground-based measurements & 34 & 0 & 34 & 0 & 34 & 34 & - & - \\
\hline & \multicolumn{9}{|l|}{ Statistical and analytic qualities } \\
\hline & $\begin{array}{l}\text { 3. Sampling grid } 5 \times 5 \mathrm{~km} \text { (ground-based } \\
\text { measurements) }\end{array}$ & 34 & - & 34 & - & 34 & 34 & - & - \\
\hline & $\begin{array}{l}\text { 4. Sampling grid } 2.5 \times 5 \mathrm{~km} \text { (remote } \\
\text { sensing) }\end{array}$ & 34 & . & 34 & $\cdot$ & 34 & 34 & - & - \\
\hline & 5. Sample size $(n=30)$ & 34 & - & 34 & - & - & - & - & - \\
\hline & $\begin{array}{l}\text { 6. Statistical measures of precision and } \\
\text { accuracy }\end{array}$ & 34 & 0 & 34 & 0 & 0 & 0 & 0 & 0 \\
\hline & 7. Transparency of methods & 0 & 0 & 0 & 0 & 0 & 0 & 0 & 0 \\
\hline \multicolumn{2}{|c|}{ Total number of reports } & 34 & 34 & 34 & 34 & 34 & 34 & 34 & 34 \\
\hline
\end{tabular}

\subsubsection{Sampling and plot-design}

In order to answer the question of relevant assessment methods, the following section describes the inventory designs and methods that were chosen for the individual reports. Their characteristics such as sample size, plot designs and statistical measures of uncertainty shall allow conclusions on quality requirements of national data providers.

In Sweden, habitat monitoring and reporting was harmonised, i.e. all habitats were assessed by comparable methods and all reports included assessments from three programmes:

(1) The national forest inventory (NFI) which also includes assessments for the "National Survey of Forest Soils and Vegetation" (SK), 
(2) The "National Inventory of Landscapes in Sweden" (NILS), and

(3) The project "Demonstration of an Integrated North-European system for Monitoring Terrestrial Habitats" (MOTH).

The motivations for the extension of NFI by other programmes had been described by Gardfjell et al. (2007) and Ståhl et al. (2011). Accordingly, the intention of the new protocol was to respond to political processes and data requirements, especially those of the European Habitats Directive. Thus, by the start of the next 5-year inventory phase in 2008, NFI was extended by NILS to include new variables on biodiversity and designated habitats. The assessments were further extended towards areas in- and outside forests and thus removed problems originating from incompatible forest definitions of the NFI and the Habitats Directive. Both inventories further used the same basic sampling design with a systematic sampling grid of stratified 5 x $5 \mathrm{~km}$ "landscape units" for extensive measurements (Figure 8). Their common sampling method was further randomised by an approach were both the starting point and the spatial orientation of the grid were randomly selected. NILS improved NFI estimates by additional field plots in difficult terrains of mountainous regions. The inventories used a standardised plot design where each landscape unit had a central $1-\mathrm{km}$ square for intensive aerial photo interpretations and identification of habitat types. Inside that square, a central $750 \mathrm{~m}$ square included a cluster of 12 circular sub-plots for field-based observations along edges. Every sub-plot was further composed of nested sub-plots of different size for different types of observations to optimize accuracy of estimates. (cf. Figure 8 and Gardfjell and Hagner, 2014; Ståhl et al., 2011).

Sampling intensity of these inventories was however considered insufficient for monitoring rare habitats (Gardfjell et al., 2007). In fact, for monitoring areas of European habitat types the inventory design targeted a minimum number of 30 sample plots with confirmed habitat types per "biogeographical region" (in Sweden: Alpine, Boreal, Continental, cf. Ch. 4.3) for an approximation, and 100 plots for a "reliable" estimate (SLU, 2015b). To reach the target precision levels (Figures 9 and 10), a two-phase design combining interpretation of aerial infrared imagery and stratification of potential habitat areas with field measurements started in 2009 (Figure 11) (Gardfjell and Hagner, 2014). MOTH eventually allowed identification of rare habitats because it superimposed a denser $5 \times 2.5 \mathrm{~km}$ grid on each $5 \times 5 \mathrm{~km}$ NILSsampling unit (Forsman et al., n.d.). A key for habitat identification then guided interpreters in assigning broad "aerial interpretation classes" to each point. In the second phase, a certain percentage of field-plots was randomly selected from each class (Forsman et al. n.d.). These 
were measured directly in the field and thus allowed validation of image interpretation. In addition to its ability to measure rare habitat types another advantage of MOTH was its ability to identify very small patches of habitat types. This was made possible by high resolution aerial imagery at $0.5 \mathrm{~m}$ (Landmäteriet, 2017).

In summary, the described methods of NFI, NILS and MOTH allow inferences on 6 quality criteria that were important to inventory developers.

\section{Measurement methods:}

(1) Remote sensing at a spatial resolution of $0.5 \mathrm{~m}$ and

(2) Ground-based measurements.

\section{Statistical and analytical qualities:}

(3) A 5 x $5 \mathrm{~km}$ sampling-grid for ground based measurements,

(4) An intensified $2.5 \mathrm{~km}$ x $5 \mathrm{~km}$ sampling-grid for remotely sensed images and groundtruthing of each "aerial interpretation class" with of a specific percentage of field-plots (i.e. "ground truthing" = verifying the "truth" of image classifications by field observations "on the ground")

(5) A defined minimum sample size of at least $n=30$ per habitat type and biogeographical region,

(6) The ability to generate statistical estimates of precision and accuracy. 

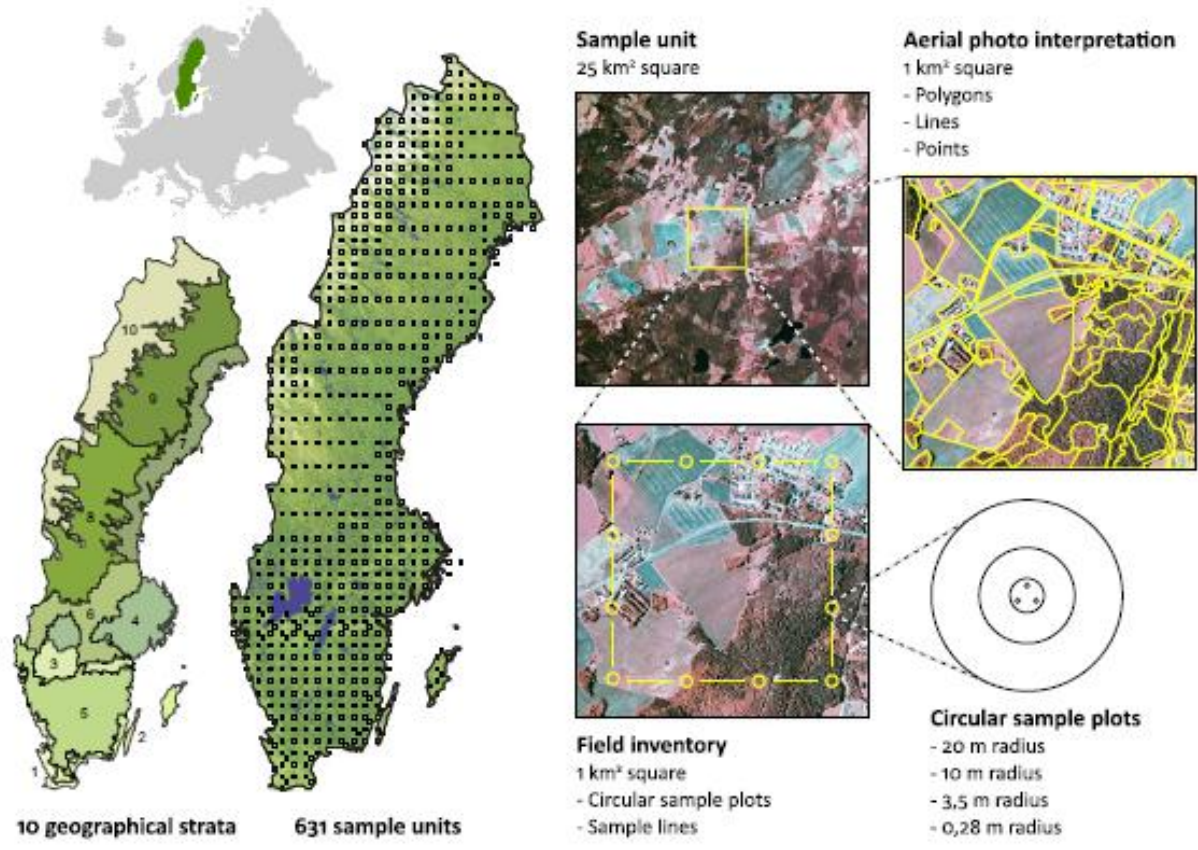

Figure 8. Overview of the NILS sampling design. The design is a systematic sampling design with pre-stratification into 10 strata. Each $5 \times 5 \mathrm{~km}$ landscape unit has a $1-\mathrm{km}^{2}$ square in the centre. Habitats are mapped by aerial photo interpretation and field-sample plots (from Ståhl et al., 2011).

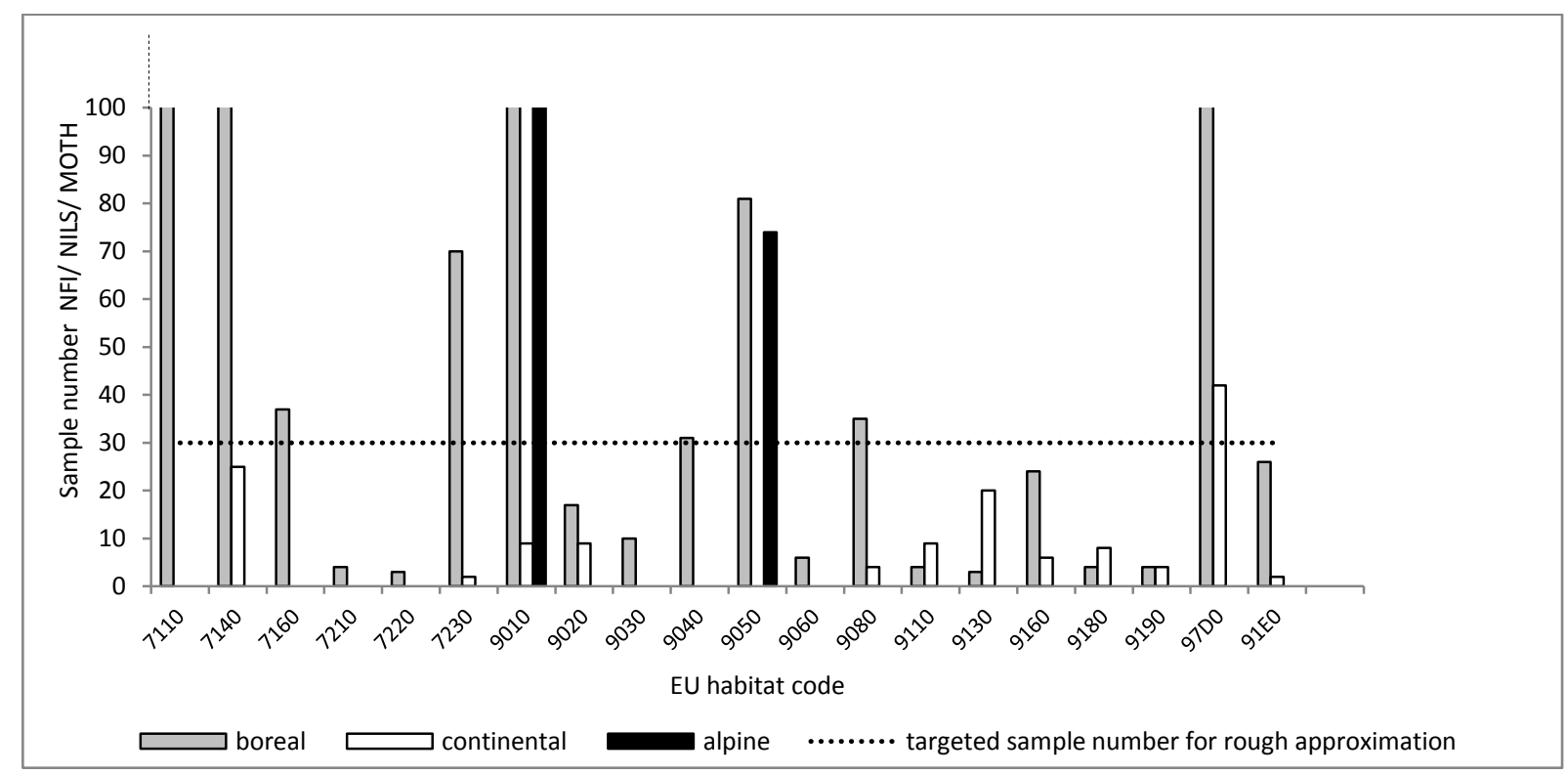

Figure 9. Requirements of sample number and achievements by the NFI/NILS/MOTH inventory design (estimates provided by SLU) 


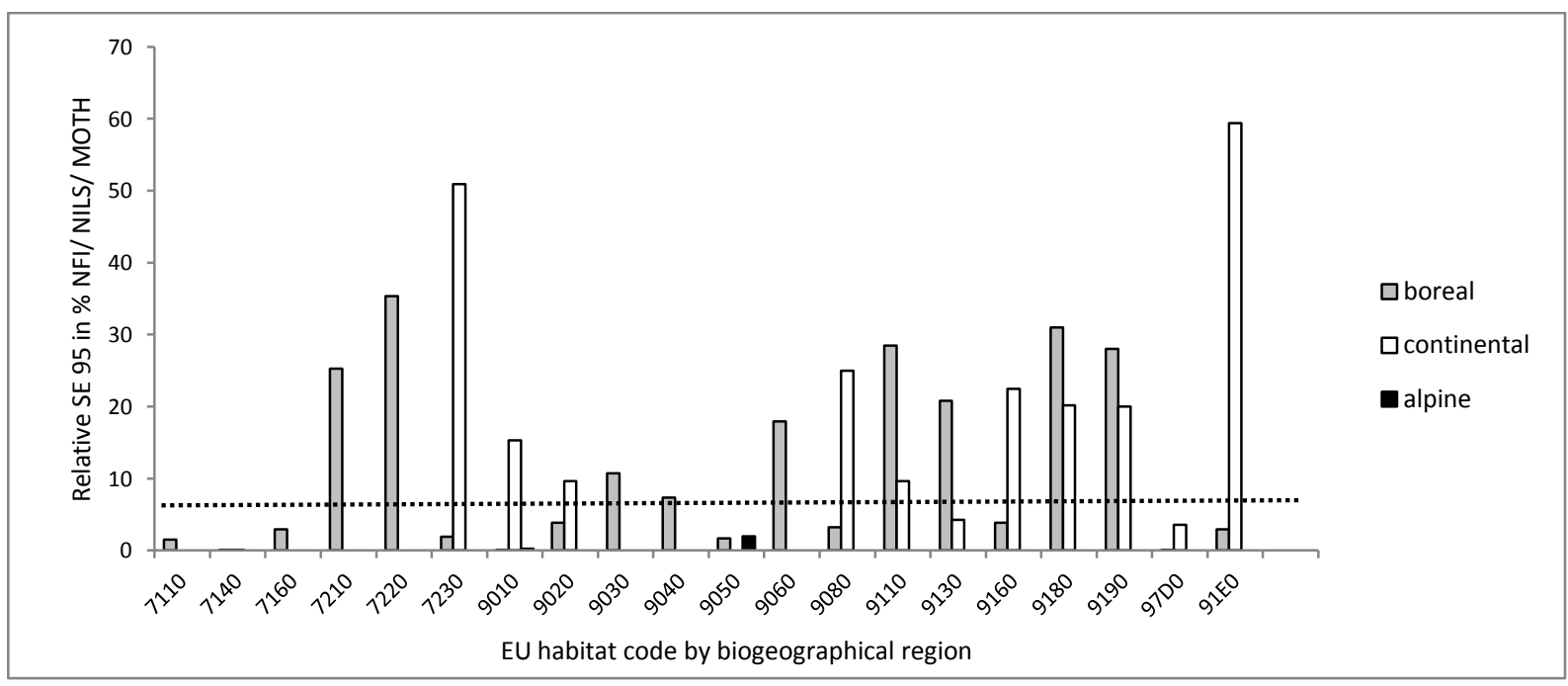

Figure 10. Requirements of statistical precision and achievements by the NFI/NILS/MOTH inventory design (dotted line shows relative standard errors as required for "rough" estimations at $n=30$ sample size) (data provided by SLU)

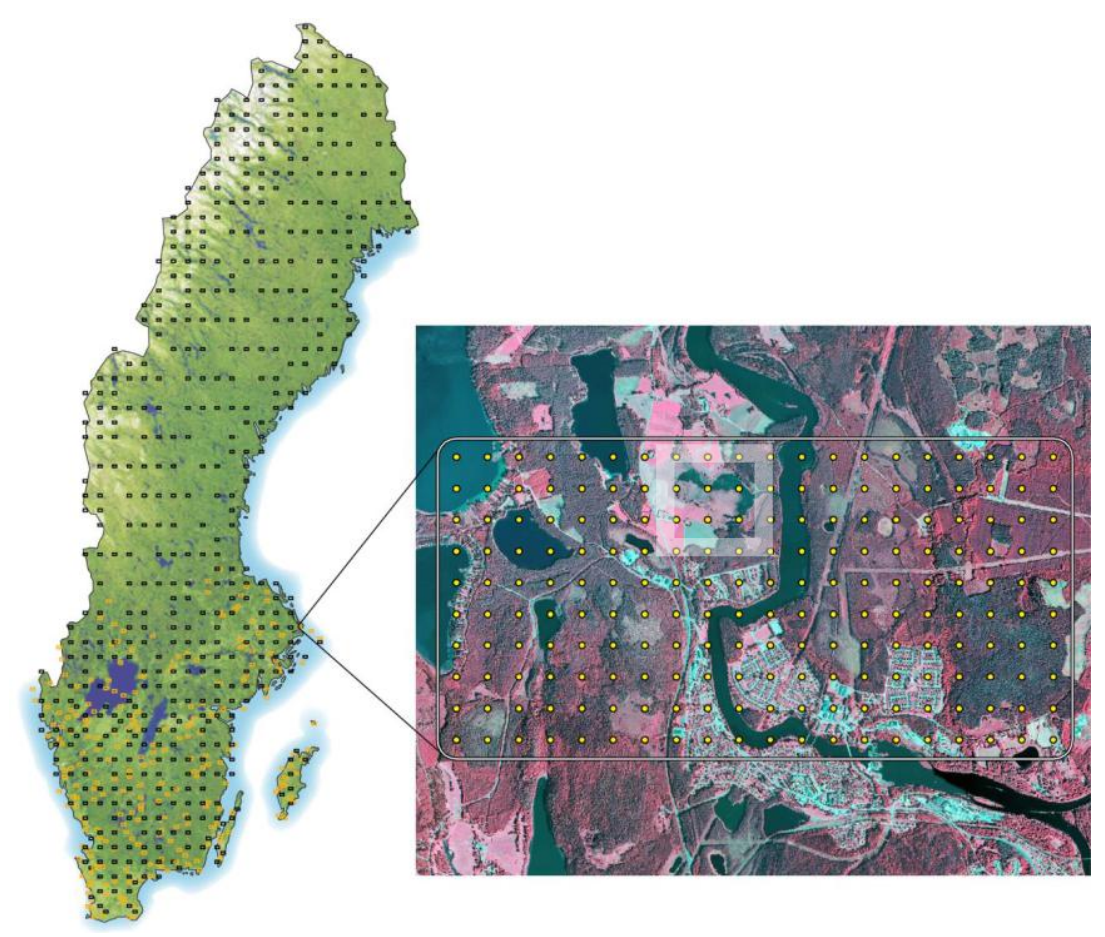

Figure 11. MOTH 2-phase sampling for stratification with aerial infrared imagery and overlap with NFI sample plots. The map shows the 565 stratified sample units. Infrared images are acquired for every unit and a $5 \mathrm{~km} \times 2.5 \mathrm{~km}$ point-grid is superimposed. The 200 points are interpreted and visually classified. 12 of the of the 2000 MOTH grid points overlap with 12 NILS field sample plots (highlighted by the white shaded frame). In the second phase, a percentage of MOTH points in every class is randomly selected for field visits. (amended after: Gardfjell, 2014; Adler, 2014) 


\subsubsection{Reporting "Habitat area" and "Range"}

Having identified the relevance of inventory designs and the minimum requirements for statistical measures of data quality in the previous chapter, the following section looks at the relevance of transparent assessment methods for the variables habitat "area" and "range". The analysis is based on the evaluation of measurement and assessment methods of the Swedish field protocol of SLU (Gardfjell and Hagner, 2014). Detailed results on the number of nontransparent variables and assessment methods that contributed to each of the 34 habitat area reports are presented in Table 29. It shows that all of the 34 habitat area assessments included at least one variable for which the protocol of field measurement is non-transparent. These results are also summarised in Table 30 which lists the quality characteristic "data transparency" under bullet-point 7. The remaining points 1-6 are adapted from previous analysis of Chapter 4.5.3.2, where I have already described and identified quality characteristics of the sampling-and plot design.

The background and reason for the observation of non-transparent area-reports is that in all habitat area-measurements, the Swedish rule said that EU-habitats classify as such only, if natural or anthropogenic disturbances such as "chemical-" or "hydrological impact", "largescale-" and "limited exploitation" led to negative effects on the physical state (Gardfjell and Hagner, 2014). These descriptions are qualitative and ambiguous because they do neither include a measurement scale, nor thresholds for classifying disturbances as "large-scale" or "limited". Though most of the other variables were measured by clearly defined and standardised methods, the vague description of disturbances still meant that field experts could make own specifications and interpretations. These expert-depended choices and methods are not documented and therefore difficult to verify, i.e. "non-transparent" along the meaning of this term as used in my analysis. 
Table 29. Relevance of data sources and transparency in "habitat area" and "range" assessment. Data on sampling effort and precision kindly provided by SLU.

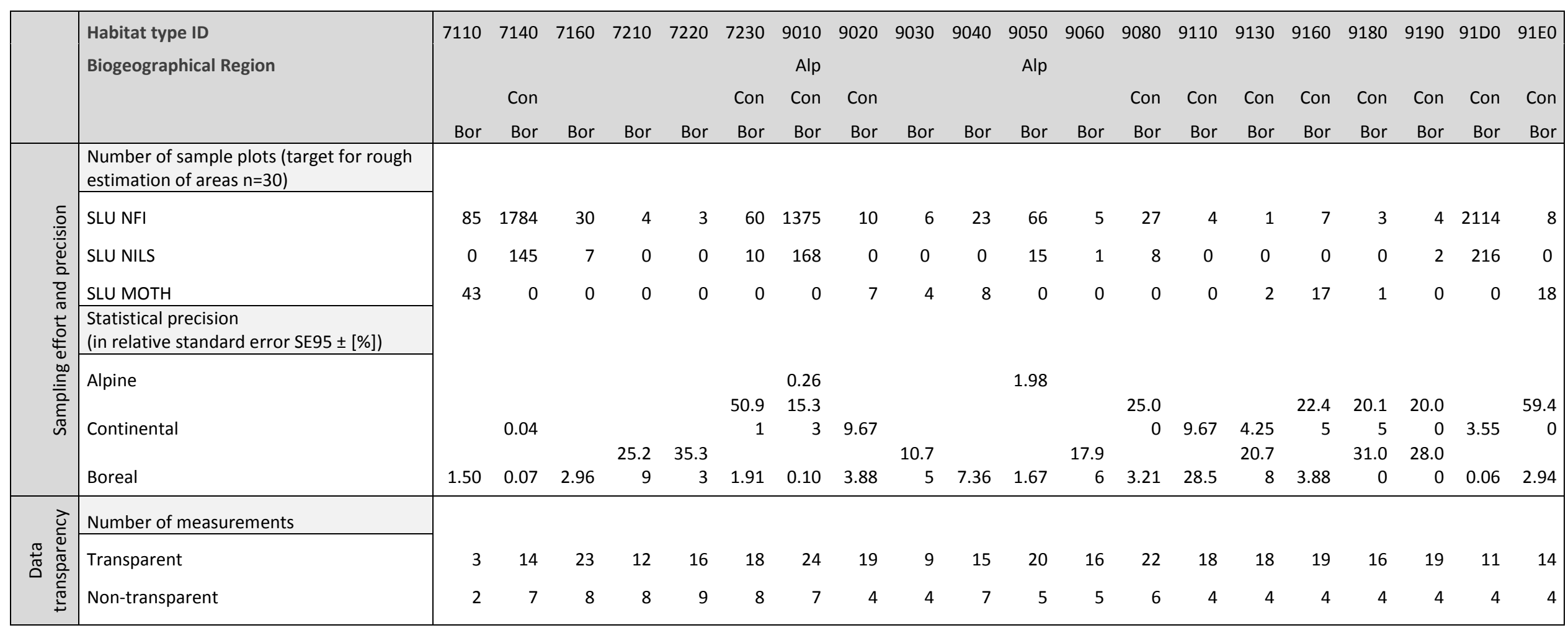


Table 30. Relevance of data quality criteria in Swedish reports on the variables "habitat area" and "range". Data quality criteria were identified by characteristics of inventory methods. Under the headline "relevant", numeric figures shows how many of the 34 reported values satisfied the individual data quality requirements.

\begin{tabular}{|c|c|c|c|}
\hline Data quality criteria & Relevant $^{1}$ & Irrelevant & Total \\
\hline \multicolumn{4}{|l|}{ Measurement methods } \\
\hline 1. Remote-sensing at $0.5 \mathrm{~m}$ resolution & 34 & 0 & 34 \\
\hline 2. Ground-based measurements & 34 & 0 & 34 \\
\hline \multicolumn{4}{|l|}{ Statistical and analytic qualities } \\
\hline 3. Sampling grid 5 x $5 \mathrm{~km}$ (ground-based measurements) & 34 & 0 & 34 \\
\hline 4. Sampling grid $2.5 \times 5 \mathrm{~km}$ (remote sensing) & 34 & 0 & 34 \\
\hline 5. Sample size $(n=30)$ & 34 & 0 & 34 \\
\hline 6. Statistical measures of precision and accuracy & 34 & 0 & 34 \\
\hline 7. Transparency of methods & 0 & 34 & 34 \\
\hline
\end{tabular}

\subsubsection{Reporting the "Conservation status"-index of "Habitat area" and}

\section{"Range"}

Having described the methods of measuring habitat areas and ranges, the following section describes how Sweden assigned indexes of "conservation status" to such measurements. For that purpose, I describe the methods of index compilation and the specific qualities and intransparencies in that assessment.

As a general rule, the purpose of the indexes was to qualify the respective measurements and values of "area" or "range" as either "favourable", "unfavourable" or "unfavourable-bad". The purpose of such qualification was to describe if areas or ranges were big enough to support and ensure the future growth or survival of forest habitat types. The index was thus compiled by three components (1) "current coverage"-, (2) "trend"- and (3) "favourable reference values". These input values were provided by three different sources and measured in three different ways. Table 31 shows that only "current coverage" was assessed by precisely defined, i.e. transparent methods of the NFI, NILS and MOTH. On the basis of these methods, inventory authorities were able to estimate and provide measures of statistical uncertainty.

The remaining sources and their methods remained obscure. The reason is that for "trends"assessment the sources did not become entirely clear from the report. It states that due to lack of re-inventory data form NFI, NILS and MOTH, trends were assessed by extrapolating 
general trends from other national statistics or research studies or from other information (report submitted by Swedish Environment Protection Agency, 2013). The precise sources and methods however remained non-transparent because the report neither mentioned extrapolation methods, nor background measurements.

Sweden assessed the third component of the conservation status index, the "favourable references area" using method of Angelstam and Andersson (2001) who established that for "long-term survival", the forest habitat area needed to be at least $20 \%$ of "all forest land". That data came from NFI. Yet, expert opinion of expected pressures was used to adjust results (Swedish Environment Protection Agency, 2013). The lack of transparency of that decision eventually translated in the compiled conservation status index (Table 31).

Table 31. Relevance of data quality criteria in Swedish reports on "conservation status indexes" of habitat "area" and "range ". Data quality criteria were identified by characteristics of inventory methods. Under the headline "relevant", numeric figures shows how many of the 34 reported values satisfied the individual data quality requirements.

\begin{tabular}{|c|c|c|c|c|}
\hline $\begin{array}{l}\text { Data } \\
\text { sources }\end{array}$ & Data quality criteria & Relevant $^{1}$ & Irrelevant & Total \\
\hline \multicolumn{5}{|c|}{$\mathrm{NFI} / \mathrm{NILS} / \mathrm{MOTH}$ (coverage and trend assessment) } \\
\hline & $\begin{array}{l}\text { 1. Remote-sensing at } 0.5 \mathrm{~m} \text { resolution } \\
\text { 2. Ground-based measurements } \\
\text { 3. Sampling grid at least } 5 \times 5 \mathrm{~km} \text { (ground-based } \\
\text { measurements) } \\
\text { 4. Sampling grid density } 2.5 \times 5 \mathrm{~km} \text { (remote sensing) } \\
\text { 5. Sample size }(n=30) \\
\text { 6. Statistical measures of precision and accuracy } \\
\text { 7. Transparency of methods }\end{array}$ & $\begin{array}{r}34 \\
34 \\
34 \\
\\
34 \\
34 \\
34 \\
0\end{array}$ & $\begin{array}{l}0 \\
0 \\
0 \\
0 \\
0 \\
0 \\
34\end{array}$ & $\begin{array}{l}34 \\
34 \\
34 \\
\\
34 \\
34 \\
34 \\
34\end{array}$ \\
\hline \multicolumn{5}{|c|}{ National statistics, research studies or other info (Trend assessment) } \\
\hline & 6. Transparency & 0 & 34 & 34 \\
\hline \multicolumn{5}{|c|}{ Expert opinion (index compilation for "conservation status) } \\
\hline & $\begin{array}{l}\text { 7. Statistical measures of precision and accuracy } \\
\text { 8. Transparency }\end{array}$ & $\begin{array}{l}0 \\
0\end{array}$ & $\begin{array}{l}34 \\
34\end{array}$ & $\begin{array}{l}34 \\
34\end{array}$ \\
\hline
\end{tabular}




\subsubsection{Reporting "Threats and pressures", "Specific structures and functions", and "Future prospects" of habitat types}

The previous section had identified the report-relevant quality criteria within the indexes of conservation status for the two variables habitat "area" and "range". Now I continue to analyse quality standards within the remaining two indexes for the variables (1) "structures and functions", (2) "future prospects" and (3) "threats and pressures".

According to the EC-definition and guideline documents (Evans et al., 2011; EC DG Env., 2013), the index for "specific structures and functions" describes, if a member state believes that physical components of a habitat type such as dead wood and species composition are good enough to allow future provision of ecosystem services and functions (e.g. nutrient cycling) (Evans et al., 2011). As to what types of variables measure the respective conditions are to be defined by the member state.

The situation for the assessment of "future prospects" is quite similar. The index generally describes if anthropogenic impacts are believed to allow future maintenance and growth of the habitat type as a whole, including the maintenance of the habitat's spatial extent, its physical composition and the provision of its ecosystem services and functions (EC DG Env, 2013). Also here, member states made their own specifications.

To allow conclusion on these national quality requirements, I identified the Swedish methods of measuring and analysing the indexes and presented them in Table 32. They show that in Sweden, the compilation of the indexes was not precisely defined, and authorities decided mainly on a subjective basis using expert opinion. The input data that informed such decisions was difficult to identify. However the national report (Swedish Environment Protection Agency, 2013) suggests that measurements on the third variable, i.e. "threats and pressures", played an important role: accordingly indexes got assigned a "favourable" value only, if threats and pressures remained absent within the next two reporting cycles, i.e. until the year 2025. One or more occurrences usually resulted in categorisations of "unfavourableinadequate" (U1) or "bad" (U2) (Swedish Environment Protection Agency, 2013). Yet the measurement techniques for occurrences and forecasts of such threats and pressures remained non-transparent from the available documents. An indication supporting that conclusion is that, according to the national reports (Swedish Environment Protection Agency, 2013), threats and pressures were identified "based on logical reasoning" (cf. Box 9), a method 
which is most likely to be subjective expert opinion where the background variables are difficult to verify.

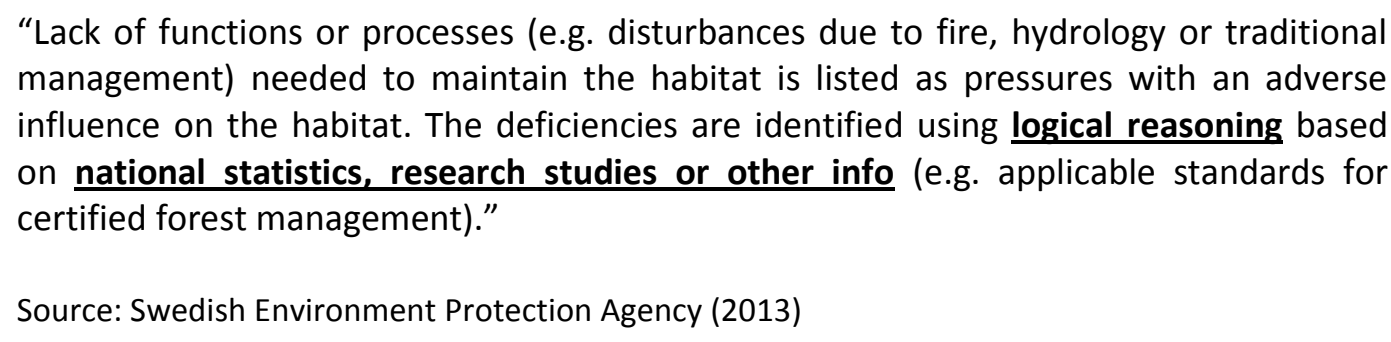

Box 9. Data source and assessment of the conservation status component "Structures and Functions" according to Swedish National Report (Swedish Environment Protecion Agency, 2013)

Table 32. Relevance of data quality criteria in Swedish reports on "conservation status indexes" of "structures and functions" and "future prospects". Data quality criteria were identified by characteristics of inventory methods. Under the headline "relevant", numeric figures shows how many of the 34 reported values satisfied the individual data quality requirements.

\begin{tabular}{|l|l|r|r|}
\hline Data sources & Data quality criteria & Relevant $^{1}$ & Irrelevant $^{\text {Total }}$ \\
\hline Expert opinion (Threats and pressures - status and forecast until 2025) & 0 & 34 & 34 \\
\hline & $\begin{array}{l}\text { 3. Statistical measures of precision and accuracy } \\
\text { 4. Transparency }\end{array}$ & 0 & 34 \\
\hline \\
Data was assumed to be relevant to the monitoring and reporting process, when an involved \\
authority decided to use such information.
\end{tabular}

\subsubsection{Risk of political bias (Q2)}

Having answered the question of data requirements before, this section's ambition is to contribute to the second research question and to make inventory specialists aware of the risks of political bias that may be associated with monitoring and reporting processes. To identify such risks and in accordance with methods employed in the German case study, I first analysed the motivations and interests of data providers. The purpose was to classify these motivations as either more science- or more policy-focused and to clarify if there might be any conflict of interest with scientifically-based assessments. In a second step, I assessed the 
extent to which non-transparent assessment methods really provided options for political interests to bias assessment results.

The question of motivations was answered by identifying responsibilities of data providers. In Chapter 4.5.2, we have found that only one authority, a university, was involved in measurement and analysis. Its main responsibility was to create scientifically credible evidence. This is at least indicated by the fact that methods developed for reporting purposes were largely published in peer reviewed journals and verifiable by the scientific community (Table 33). The background motivation for choosing specific methods is therefore more likely to be a scientific one, where assessment seeks credibility among the scientific community. There was thus no evidence for us to conclude that it would have been of any political benefit for the university to bias or skew results towards a politically favoured outcome.

At least, political stakeholders such as ministries and agencies, were involved only indirectly via funding and co-defining research questions, for instance via the EC-LIFE+ fund for inventory development. However, policy-makers and their interests could not influence the output as they were not directly involved in data acquisition- and interpretation processes. Any active manipulation would have further been easily spotted either during peer review or after publication, posing too much risk to a scientific intuition that depends upon its scientific reputation. Table 34 illustrates that there was no evidence for us to conclude that political interests could have influenced or biased research output in any way.

Table 33. Research focus of SLU indicated by the 2013-2016 publications. The publications list was acquired from the SLU webpage. It contains articles and reports that use NFI data as a source. (http://www.slu.se/en/Collaborative-Centres-and-Projects/the-swedish-national-forestinventory/publications/)

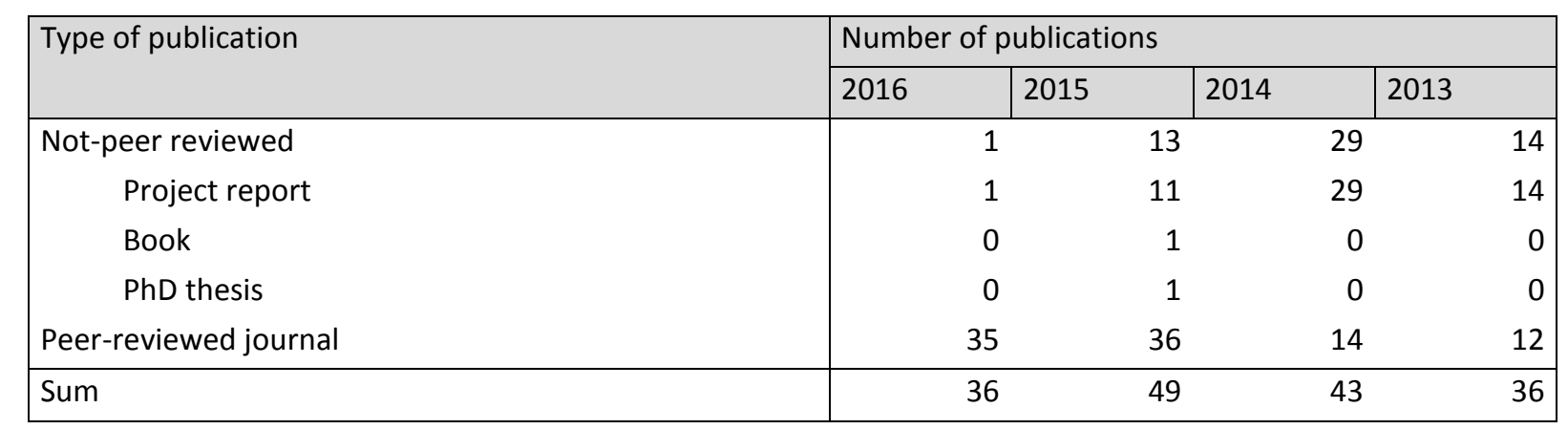


Table 34. Risk of political bias within Swedish monitoring and reporting programmes under Habitats Directive. The table describes risk of political bias as a function of political motivations and non-transparent assessment methods. Political motivations are confirmed when the institutions' responsibilities could come into conflict with monitoring responsibilities. Lack of transparency is quantified by the number of reported values with not completely verifiable assessment methods.

\begin{tabular}{|c|c|c|c|c|c|c|c|c|c|}
\hline$\frac{\grave{d}}{\frac{0}{\partial}}$ & $\begin{array}{l}\text { Consulted } \\
\text { authority }\end{array}$ & Swedish $\mathrm{C}$ & Iniversity o & f Agricultur & ral Science & (SLU) & & & \\
\hline & Report criteria & Habitat ar & & & Range & & & & \\
\hline 这 & & $\begin{array}{l}\text { Cover } \\
\left(\mathrm{km}^{2}\right)\end{array}$ & $\begin{array}{l}\text { Trends } \\
(+, 0,-)\end{array}$ & $\begin{array}{l}\text { Overall } \\
\text { status } \\
\text { (index) }\end{array}$ & $\begin{array}{l}\text { Cover } \\
\left(\mathrm{km}^{2}\right)\end{array}$ & $\begin{array}{l}\text { Trends } \\
(+, 0,-)\end{array}$ & $\begin{array}{l}\text { Overall } \\
\text { status } \\
\text { (index) }\end{array}$ & $\begin{array}{l}\text { Overall } \\
\text { status } \\
\text { (index) }\end{array}$ & $\begin{array}{l}\text { Overall } \\
\text { status } \\
\text { (index) }\end{array}$ \\
\hline 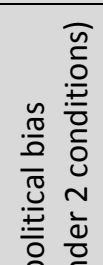 & $\begin{array}{l}\text { 1. Political } \\
\text { motivation/ } \\
\text { conflict of } \\
\text { interest (as a } \\
\text { result of other } \\
\text { responsibilities) } \\
\end{array}$ & & & & & - & & & \\
\hline 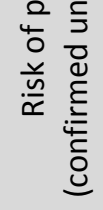 & $\begin{array}{l}\text { 2. Lack of } \\
\text { transparency of } \\
\text { methods }\end{array}$ & 34 & 34 & 34 & 34 & 34 & 34 & 34 & 34 \\
\hline Total $n$ & umber of reports & 34 & 34 & 34 & 34 & 34 & 34 & 34 & 34 \\
\hline
\end{tabular}

It is interesting to observe that though lack of transparency was unlikely to be politically motivated, its occurrence within the monitoring programme was still widespread (Table 34). Based on my evidence on the scientific background of inventory authorities, this observation might be better explained by a scientific motivation to provide best possible evidence in a situation where optimal or perfect information is difficult to acquire. In fact, a completely standardised and transparent inventory design could be difficult to implement. Even within the scientific community, there is yet little consent on how to translate political concepts such as "favourable conservation status" into optimal variables and thresholds. So far, many different interpretations and methods have been proposed (Epstein et al., 2015; Lindenmayer et al., 2000; Rondeux and Sanchez, 2010; Laikre et al., 2009; Noss, 1990). Yet the lack of consent between these different assessment methods is partly explained by the complexity of environmental settings which is not always easy to grasp or standardise by measurement. 
These problems apply specifically to the heterogeneous landscape of Sweden. It covers large areas of land, including uninhabited areas with poor infrastructure and inaccessible terrains of mountainous regions. In these landscapes, environmental processes are extremely difficult to study, which means that a-priori desk-based definitions of indicators carry the risk of excluding environmentally relevant but yet unknown effects. In these cases, assessment by visual estimation and expert opinion has advantages: It allows field biologists to look at a larger range of processes, to assess their multiple effects and identify yet undiscovered pressures. Vague definitions thus contribute to completeness of environmentally relevant information, but in expense of transparency of the data generation process.

Also other inconsistencies such as those resulting from the expert-based interpretation of trends and conservation status are explained by absence of better information. The reason was lack of re-measurements and difficulties to predict the effect of management-induced disturbances. According to the Habitats Directive, the assessment of (future) "threats" and "future prospects" required forecasts until 2025 and in-depth background evidence to allow such forecasts of long-term trends. Comparable and long-term observations however were not yet available from the first inventory phase. These are likely to be available in future because the inventory is a long-term project with constant improvement (Fridman et al., 2014). Remeasurements are therefore likely to create a better database that improves the estimation of trends and the prediction of threats in the near future. This suggests that gaps of transparency identified in my study will likely be removed over time and are not rooted in any wicked political interest to hide or skew information towards a politically preferred outcome

\subsection{Conclusion}

\subsubsection{Relevance $(Q 1)$}

The first objective of this thesis was to identify politically relevant forest information. I differentiated 3 components: required (1) attributes, (2) quality characteristics and (3) providers. I have first identified attributes defined by the reporting format of the receiver, i.e. the European Commission. Results showed that the European Commission demanded attributes informing on area, range, specific structures and functions and future prospects of specific forest habitat types. However, in terms of quality requirements, the EU documents remained vague. 
I then identified data sources and specific quality characteristics that were regarded relevant by the national providers. In this approach, I have analysed reports submitted by Germany and Sweden. These provided evidence on politically trusted data providers and their quality requirements.

The results showed that in Germany, the authorities who set the national quality requirements were mainly administrative bodies, whereas the Swedish government put in charge a university whose work was mainly targeted towards the scientific audience. Depending on these different affiliations, which were either more targeted towards scientific or to political audiences, also quality requirements were very different in Germany and Sweden. Especially statistical quality requirements were perceived in various ways. In the German reports submitted under Habitats Directive, statistical uncertainties, as they are common in sciencebased inventories, were used less frequently. Specifically assessments of areas and of threats and pressures are still without such statistical measures of precision or accuracy because they were mainly based on biotope mapping where neither reports provided such information, nor did manuals suggest that methods included spatial estimates allowing estimation of statistical precision and accuracy.

Probability based assessments in contrast, such as those generated via the NFI, were relevant only for numeric information such as the abundance of habitat trees and species composition. Instead, for purposes of assessing spatial information on areas and ranges of habitat types, probability-based sampling was regarded insufficient because sampling naturally covers only a small area and limited component of the overall landscape. Reporting authorities then preferred assessments based on visual interpretation of aerial imagery and occasional site visits. However, neither image interpretation, nor site visits followed standardised and documented rules. Especially limitations in techniques of randomisation and ambiguous, i.e. non-transparent methods of measuring and assessing variables were an issue. That ambiguity allowed expert-dependent interpretations during site visits and complicated inferences on statistical qualities such as statistical precision and accuracy.

Information based on principles of statistical sampling and assessment of uncertainty had prevalence in Sweden. The two-phase sampling design with a standardised imageclassification key and field measurements complied with statistical principles and further allowed a more targeted approach towards sampling rare habitat types. Most methods of measurement were precisely defined. Only those variables that were difficult or too time 
consuming to measure by standardised methods where assessed by the non-transparent rules of expert assessment. Examples were management-induced effects, and forecasts of (future) "threats" and "future prospects". Their measurement were similarly challenging in Germany. Thus, in the absence of better or more efficient methods, both countries largely relied on expert opinion.

\subsubsection{Risk of political bias (Q2)}

The second objective of this work was to make scientists aware of potential risks of political bias that may influence the information generation process. Following the theory presented in Chapter 1.2 and 1.3, it was checked if the following two hypothetical conditions might give rise to concerns about political bias: 1) political motivations are in conflict with scientific interests, and 2) Non-transparent assessment rules allow these political motivations to implicitly influence assessment results.

Even though I have identified non-transparent assessment rules in both countries, it was only in one case, where I could find political interests to be in conflict with scientific assessment results. German law allows that the selection of samples and identification of new habitat types could come under responsibility of forest owners or stakeholders that plan an so-called intervention with potentially adverse effects on nature and landscape ( $\S 14, \S 19$ and $\S 34)$. If these intended heavy-impact projects or intrusive management practices on their lands, then they were obliged to screen the appointed sites for occurrence of EU-habitat types and to compensate for environmental losses according to rules of $\S \S 19$ and $\S 34$ BNatSchG. According to these rules, confirmed occurrence of habitat types usually results in a monetary burden to those who planned the invention, i.e. those who did the inventory. Costs may be even higher if the habitat type is found to be at favourable conservation status. Then there is a legal obligation to maintain that highest possible status and to implement most rigorous measures of protection.

These observations showed that economic interests were at odds with scientific monitoring responsibilities, and this conflict may possibly motivate data providers to bias assessment results. At least from the forest owner's perspective, the option to hide unwanted evidence of habitat types and to avoid costs resulting from regulatory or monetary implications seems to be appealing. The distribution of monitoring responsibilities towards actors with economic interests is therefore a potential source of political bias, especially in area-assessments. 


\subsection{Outlook on options of limiting risks of political bias}

\subsubsection{Distribution of responsibilities}

The previous sections have identified potential sources of political bias within national reporting processes. These findings indicated that two factors were key to limiting such bias: 1) avoiding conflict of interest and 2) finding alternatives to non-transparent assessment methods such as expert opinion and ill-standardised inventory designs. The following section collects ideas on improving the inventory design towards more transparent and more sciencebased information.

As a first recommendation, the involvement of a politically independent institution such as a university or a research institute could limit the stake of political motivations in the monitoring process. At this point, it is important to make sure that economic interests evolving from other administrational responsibilities such as land-use planning, site management and protection obligations do not interfere with scientific interests of those responsible for monitoring. Optimally, the complete monitoring and reporting process should be in hands of independent scientific institutions. Sweden has already developed such a model where a strong research focus of monitoring institutions protects scientific credibility.

Also independent funding schemes can ensure scientific independence. Sweden already uses that option. By means of the independent EU LIFE+ research fund, it gains the scientific independence necessary for the development of new remote-sensing-based methods for habitat area assessment. In Germany however, costs are covered by a complex mix of governmental funds from Federation, States and research funds. In addition, under specialised regulations of environmental impact assessment $\S \S 14$ and $\S 19$ BNatSchG, costs for area assessments could be funded by land owners or stakeholders who plan potentially harmful management practices. Such assessments are unable to ensure scientific independence because the money comes from stakeholders that have a political interest in forests. Funds dedicated to research and provided by politically independent donors could be an alternative option to complement the financial basis.

Since the extension of the monitoring mandates towards a cooperation of centralised government research institutes, a transition of monitoring responsibilities and cooperation with scientifically more independent institutes became observable in Germany. Both, the Thünen Institute and BfN, are government research agencies without direct access to land-use 
rights. Though they are run under the departments of different ministerial resorts (utilitarian vs. conservation) and therefore answer different and sometime opposing political questions, we may assume that the need for cooperation and compromise on such different questions contributes to mutual review, complementary of questions answered and an information system that responds more comprehensively to the diverse nature of the policy-regimecomplex.

The mandates of centralised governmental research agencies, however does not yet extend towards information that is politically most sensitive, i.e. those that come with monetary implications. Especially area assessments of habitat types often continue to be a partial responsibility of forest owners or of stakeholders that plan intervening activities such as construction work. If they find evidence on habitat types, then this usually leads to the obligation to protect those sites. Such protection then usually means statutory regulation of forest management or it results in a monetary burden. Both could create a conflict of interest with monitoring responsibilities. To avoid such conflicts, options could be discussed to put habitat area monitoring and reporting under authority of centralised and independent institutes that have no stake in land-use rights and are not affected by management regulations.

This requires, however, a new national inventory mandate, something that German authorities have achieved for the assessment of "structures and functions". Habitat "area" assessments, however still fall under the federal principle of Article 30 of German Constitution and remain the prerogative of Federal States and their bureaucratic monitoring authorities. Therefore, national harmonisation efforts and agreement on new assessment methods always require discourse and compromise. This process might be frustrating from an outside perspective because it slows down the decision-making process, and new technologies and new "scientific" knowledge need time to get implemented on a national level. However, discourse also guarantees democratic principles and avoids centralisation of power.

\subsubsection{Improving the inventory}

Besides avoiding conflicts with political interests by means of independent research funds and monitoring institutes, the second option to avoid limitations to scientific credibility is to improve verifiability of the reporting process. Transparent assessment and measurement methods are key to scientifically credible information. The Federal monitoring programmes of Germany and the integrated habitat monitoring programmes in Sweden have already made great achievements towards standardizing measurement and assessment methods on the 
national level with detailed inventory manuals and protocols. However, using the method described in Chapter 4.2.2, my study found limitations due to ambiguous or non-transparent methods ${ }^{18}$ of assessing the variables threats and pressures. Instead of using a standardised and transparent inventory design, German and Swedish authorities used expert opinion to replace the option of extensive measurements by experience.

An alternative and possibly more cost-effective option would be the integration of existing inventory and experimental designs that could allow inferences on cause-effects. The plotbased European forest health- and soil monitoring programme by UNECE/ICP Forests would be an example of an well-established inventory using principles of statistical sampling on threats and pressures that, according to its manuals and reports ${ }^{19}$ (UNECE ICP Forests Programme Co-ordinating Centre, 2016, Michel and Seidling, 2016), aims to fulfil policy information requirements on both, cause-effect relationships and statistical measures of uncertainty. The fact that this inventory is currently also being used under the CLTRAP policy with the purpose to measure pollution effects, further indicates that it is politically accepted as a useful tool to come to conclusions on relationships between human activities (threats and pressures) and their effects (forest ecosystem health). The inventory has further been employed as a default data source to the UN-FAO global Forest Resource Assessment and the Forest Europe Report "State of Europe's Forests". This acceptance, even at the higher political levels of forest policy, indicates that the design might also provide an applicable framework or starting point to harmonise assessment methods of European biodiversity policy and the Habitats Directive.

Another possible improvement of data sources to the Habitats Directive relates to observed problems with insufficient coverage of rare events in the German NFI. Habitat types with less than 63 NFI sample hits and rare structural components such as dead wood were not sufficiently covered by the standardised and unambiguous plot design. They were thus assessed by alternative methods that allow interest-based selection of samples. Authorities further preferred programmes based on remote sensing and mapping. Even though I could not find any information on precision or accuracy provided with these maps, they were preferred over NFI information and probably perceived to be more credible. Their advantages were the

\footnotetext{
${ }^{18}$ Data provided in reports was regarded non-transparent when there was no clear and unambiguous definition of sampling and plot design (e.g. location, shape and size), scale (e.g. meters) and indicator thresholds (e.g. 7 $\mathrm{cm}$ ) and analysis algorithms. (cf. Ch. 4.2.2)

${ }^{19}$ The mission of ICP Forests is "to carry out multifunctional long-term monitoring of forests within the UNECE region and beyond and provide scientific knowledge on the effects of air pollution, climate change and other stressors on forest ecosystems" (Anonymous (2016) quoted by Michel and Seidling (2016))
} 
identification of rare habitat types and the ability to provide spatial information such as connectivity, patchiness and fragmentation. In order to limit the maps' shortcomings, while at the same time taking account of its advantages, the German inventory may take the Swedish design as a starting point or idea to improve mapping efforts:

The Swedish programme further provides statistical measures of uncertainty and it addressed the problems of rare events by increasing inclusion probabilities by means of an initial phase of image-based stratification and second phase that targets ground-based measurements towards areas that have a high potential of hosting habitat types. By targeting sampling effort, the inventory thus tries to reduce costs, while at the same time, it has the advantage of fulfilling the demand for spatial information from habitat mapping. By linking standardised image interpretation/classification with ground-based sampling, and the provision of known precision levels, the assessment even went beyond political requirements and also guaranteed higher scientific standards. These advantages suggest that Swedish methods might serve as a possible starting point or inspiration to improve inventories in other countries where problems associated with expert opinion still limit transparency of biodiversity monitoring programmes. In combination with administrational redistribution of monitoring responsibilities and independent funding schemes, such a monitoring programme could then be the key to scientific independence and more science-based reporting process. 


\section{Chapter 5 \\ Case Study}

Fragmentation in EC- and UN reports to the Secretariat of the United Nations Convention on Biological Diversity 


\subsection{Introduction}

The previous chapter analysed the relevance of inventory data in German and Swedish biodiversity reporting processes to the European Commission (cf. Table 35, column Q1). Table 35 shows how the present chapter will build on these national case studies and extend them by the reporting processes from the European to the Global level. Same as in the analysis of previous case studies, also this chapter aims to identify political data requirements in terms of:

1. attributes,

2. quality characteristics and

3. most trusted data providers.

The expected results shall support inventory specialists in better informing policy processes. Evidence on political requirements and information gaps may then open up new fields of research on inventory methods that provide not only scientifically sound but also politically relevant results.

Table 35. Research questions to be answered in this thesis (the part to be analysed in this chapter is highlighted by bold frame)

\begin{tabular}{|c|c|c|c|c|c|}
\hline & & Case study & Q 1 Relevance & $\begin{array}{l}\text { Q } 2 \text { Risk of political bias } \\
\text { (confirmed under } 2 \\
\text { conditions) }\end{array}$ & \\
\hline $\begin{array}{l}\text { Interpretation } \\
\text { and decision- } \\
\text { making }\end{array}$ & National & German parliament & $\begin{array}{l}\text { 1. Attributes } \\
\text { 2. Quality } \\
\text { 3. Providers }\end{array}$ & $\begin{array}{l}\text { 1. Political motivation } \\
\text { 2. Non-transparency }\end{array}$ & Chapter 3 \\
\hline \multirow[t]{3}{*}{$\begin{array}{l}\text { Monitoring and } \\
\text { reporting }\end{array}$} & National & $\begin{array}{l}\text { Article } 17 \text { Habitats } \\
\text { Directive } \\
\text { (reports by SE, DE) }\end{array}$ & $\begin{array}{l}\text { 1. Attributes } \\
\text { 2. Quality } \\
\text { 3. Providers }\end{array}$ & $\begin{array}{l}\text { 1. Political motivation } \\
\text { 2. Non-transparency }\end{array}$ & Chapter 4 \\
\hline & Europe & $\begin{array}{l}\text { UN-CBD } \\
\text { (report by EC) }\end{array}$ & $\begin{array}{l}\text { 1. Attributes } \\
\text { 2. Quality } \\
\text { 3. Providers }\end{array}$ & $\begin{array}{l}\text { 1. Political motivation } \\
\text { 2. Non-transparency }\end{array}$ & \multirow[t]{2}{*}{ Chapter 5} \\
\hline & Global & $\begin{array}{l}\text { UN-CBD } \\
\text { (report by UN) }\end{array}$ & $\begin{array}{l}\text { 1. Attributes } \\
\text { 2. Quality } \\
\text { 3. Providers }\end{array}$ & $\begin{array}{l}\text { 1. Political motivation } \\
\text { 2. Non-transparency }\end{array}$ & \\
\hline
\end{tabular}




\subsection{Political background and research objective}

In October 2010, in Aichi Prefecture (Japan), among others, the governments of Germany, Poland and Sweden have agreed to the UNCBD 2020 Strategic Plan for Biodiversity and the so-called "Aichi targets" (UNEP/CBD/COP decision X/2, 2010). Among the targets, which I have also described in Chapter 1 and listed in Annex I of this thesis, two explicitly mentioned forests or forestry:

1. "To reduce loss of natural habitats including forests" (Aichi target 5),

and

2. "To achieve sustainable forest management on areas under forestry" (Aichi target 7). (UNEP/CBD/COP decision X/2, 2010)

The political commitment was to implement these targets by an EU Biodiversity Strategy for the period of 2011-2020, and to monitor progress. For that purpose, member states and the UN have developed policy-effectiveness indicators at two levels, the Global and the European:

The global set of indicators summarised data requirements of all signatory states to the CBD. To satisfy these requirements, the member states mandated the "Ad Hoc Technical Expert Group (AHTEG) on Indicators for the Strategic Plan for Biodiversity 2011-2020" to identify policy effectiveness indicators and to establish reporting guidelines (UNEP/CBD/COP decision X/7, 2010). Based on relevance and sensitivity to changes in CBD Aichi targets, availability of data sources, scientific validity of methods (e.g. published in peer-reviewed journals) and based on how easily indicators can be understood by policy-makers, the group selected potential data sources and finalised its most recent set of indicators in a group meeting on indicators in High Wycombe, United Kingdom, on 20-24 June 2011 (AHTEG, 2011). These so-called "operational" indicators for monitoring progress towards the CBD Aichi-Targets were then endorsed by CBD COP in 2012 (decision XI/3). Subsequently, within its most recent report, the $4^{\text {th }}$ Global Biodiversity Outlook (GBO4, published by Leadley et al., 2014), the CBD secretariat made use of some of them.

As a member to the CBD, the European Union is obliged to report to the same set of global biodiversity targets as the UN secretariat. Yet, the European interpretation of the Aichi targets is different because it needs to account not only for global policy issues but also for the more 
regional questions of European countries which are formulated by the European Biodiversity Strategy. Box 10 provides an overview of the differences and shows how the European targets want to archive the Global ones. From Box 10, it is obvious that the definitions of both, Global and European policy targets are rather vague. This is not surprising if we anticipate that global and European targets are a political compromise that must be agreed to by all member states. The range of possible interpretations is thus large enough to incorporate the very diverse policy frameworks and perceptions of biodiversity among the member states. This means that the situation becomes more and more complex, from the national, to the European and the global level. Most compromise is needed at the UN level, where global Aichi targets form a political compromise of almost all nations of the world. Vague targets and definitions eventually allow them to pursue policies that match their respective national policy frameworks. If we want to know more about the precise definitions of the member states' policy targets, then it is important to look at how reporting authorities translated rougher policy targets into measurable indicators. The data sources that members used in their respective reports are key to such indicators and will be identified in this chapter by example of the EU report to the CBD.

In its regional report, the EC uses its own dataset. It is defined by the European indicator programme "Streamlining European Biodiversity Indicators" (SEBI) and the 26 so-called SEBI indicators. The most recent set was used for the $5^{\text {th }}$ report to CBD in 2014. Similar to the global dataset, the definition of the European indicators was mainly guided by the principle of data availability at the national level and by how well such available sources corresponded to the European policy framework. Existing national data sources, such as the NFIs, were therefore relevant sources to both, the European and the global indicators. In the following sections, I will identify such national inventory programmes that were used in the reporting process. I will further assess differences in terms of 1) attributes, 2) quality characteristics and 3) most trusted data providers in three case study countries: Germany (DE), Poland (PL) and Sweden (SE). The notion of Poland shows that this chapter takes-up analysis of that specific country again, something that had to be given up in the previous chapter due to language issues (cf. Ch. 4). In the chapter at hand, analysis is possible again because the EC provided all reports in English language.

Eventually findings on EC reports, including the EC's references to the three case-study countries, want to assist inventory specialists in defining research questions and designing 
monitoring programmes that contribute to better-informed policy making on biodiversity as one of the components of sustainable forest management.

\begin{tabular}{|l|l|}
\hline $\begin{array}{l}\text { Global Strategic Plan for Biodiversity CBD COP } \\
\text { decision X/2 }\end{array}$ & European Biodiversity Strategy COM 2011/244 \\
\hline $\begin{array}{ll}\text { UN Aichi target 5: By 2020, the rate of loss of all } \\
\text { natural habitats, including forests, is at least } \\
\text { halved and where feasible brought close to zero, } \\
\text { and degradation and fragmentation is } \\
\text { significantly reduced. }\end{array}$ & $\begin{array}{l}\text { EC target 3B: By 2020, Forest Management Plans } \\
\text { or equivalent instruments, in line with } \\
\text { Sustainable Forest Management (SFM), are in } \\
\text { place for all forests that are publicly owned and } \\
\text { for forest holdings above a certain size** (to be } \\
\text { defined by the Member States or regions and } \\
\text { Communicated in their Rural Development }\end{array}$ \\
$\begin{array}{ll}\text { Ug Aichi target 7: By 2020, areas under } \\
\text { managed sustainably, ensuring conservation of } \\
\text { biodiversity. }\end{array}$ & $\begin{array}{l}\text { Programmes) that receive funding under the EU } \\
\text { Rural Development Policy so as to bring about a } \\
\text { measurable improvement* in the conservation } \\
\text { status of species and habitats that depend on or } \\
\text { are affected by forestry and in the provision of } \\
\text { related ecosystem services as compared to the } \\
\text { EU 2010 Baseline. }\end{array}$ \\
\hline
\end{tabular}

\footnotetext{
${ }^{* *}$ For smaller forest holdings, Member States may provide additional incentives to encourage the adoption of Management Plans or equivalent instruments that are in line with SFM.

"For both targets, "improvement" is to be measured against the quantified enhancement targets for the conservation status of species and habitats of EU interest in Target 1 and the restoration of degraded ecosystems under target 2.
}

Box 10. Global and European biodiversity targets on forests.

\subsection{Materials and method}

I analysed data requirements at three levels: 1) attributes, 2) quality characteristics and 3) most trusted data providers. Attributes were assumed to be relevant (to the provider) when reports used them as major source of information for measuring progress towards the 2020 biodiversity targets. This excludes illustrative information from other sources which was sometimes quoted as side information to explain or illustrate the observed achievements and trends. In the report, such side information was usually contained within the appended text that was meant to support the main facts reported in figures and tables. An example for such side information is the discussion on the status of sustainable forest management (global target 7). Here the main source of information was the area of forests managed under certification schemes. The quotation in Box 11 shows how such side information was used to discuss and interpret the assumed biodiversity effects. In the given example, it is a case study by Johansson et al. (2013). That study observed positive effects from the availability of deadwood on insect and fungal diversity. The report therefore assumed that also the effects of 
certification schemes would be positive. This was, however, only an illustration of possible effects, yet the study did not provide any evidence on the current biodiversity effects on certified areas. Such information will be excluded from analysis of policy-relevant data sources because it might provide the background to why the main source had been selected, yet it does not provide evidence on the actual issue to be reported on.

"By implementing SFM practices (which are often also part of the certification schemes discussed below) the impact on biodiversity could be reduced. For example by leaving retention trees in clear cuts some of the original habitat is maintained, which could provide benefits to many species. The availability of dead wood from different tree species positively influences insect and fungal biodiversity (Johansson et al., 2013)."

Source: Global Biodiversity outlook in Leadley et al. (2014) p. 157

Box 11. Example of how side information is used to illustrate or support major sources (major information in bold letters, side information is underlined).

To come back to the primary data sources, it is important to remind that the required quality standards were an important topic in my thesis. For this purpose and to draw inferences specifically on European and global standards, identification of inventory and measurement techniques such as sampling, remote sensing and their qualities (e.g. spatial resolution or statistical accuracy) was an important aspect. The respective evidence was collected by the method of guided literature research described in Chapter 2.2.1 (Atkinson et al., 2001; Faugier et al., 1997; Snijders, 1992; Spreen, 1992): Starting with the final report as a key document that method provided evidence on inventory protocols and the process of data generation. There were two key-documents:

(1) The first document to be analysed, i.e. the $5^{\text {th }}$ European report to the CBD Secretariat is published in two formats, as a printed version (EC, 2014b) and as a digital online database within the Biodiversity Information System for Europe (BISE, 2017). Being designed as an online data platform for information exchange between the data provider, i.e. the EC-DG Environment, and the receiving policy makers, i.e. the UN-CBD, BISE comprises the most important biodiversity indicators that currently inform international policy regulations on biodiversity. Besides presenting final forest statistics, it also provided a description of background methods and guided me to data providers that did the basic field measurements. 
(2) As for the second key document, i.e. the global report published by CBD, no such online database was available. I therefore referred to the printed version published as the " $4^{\text {th }}$ Global Biodiversity Outlook" (GBO4) by Leadley et al. (2014). Following guided literature research, I identified politically required data sources via the quotations and references made within that key-report. Additional evidence on data needs came from documents that had been published in the course of the indicator development process. An important source in this respect was COP of the CBD (2012) decision XI/3, which presented and endorsed the final set of indicators that eventually fed into the GBO4. Another source of similar importance was a protocol published before by the "Ad Hoc Technical Expert Group Meeting on Indicators for the Strategic Plan for Biodiversity 2011-2020” in High Wycombe (UK), June 2011 (AHTEG, 2011). The document was drafted in the process of indicator development and summarised the policy effectiveness indicators of the Ad Hoc Technical Expert Group. It further mentioned quality standards, some input variables and the expected data providers. As such, it provided a comprehensive overview of information that I was looking for, ranging from politically required (1) attributes, to (2) data standards and (3) the most trusted providers.

However, when extracting such information from European and global reports, it was important to note that both provided information on a large thematic scope of biodiversity targets, including sectors other than forestry, such as agriculture and fishery. Also topics that are usually not assessed by NFIs, such as economic benefits and social services were part of the published figures. As my study wanted to focus only on the relevance of forest inventory data in selected countries, I chose only those data sources that provided:

1) Variables measured/observed by inventories in Germany, Poland or Sweden, and

2) Variables measurable/observable on forest areas

These selection criteria excluded, among others, indicators measured in marine areas, rivers and lakes, and indicators on desertification. Others were excluded because they were difficult to observe or quantify and very unlikely to be part of inventories that base on statistical principles. These comprise societal benefits such as public awareness and wellbeing of communities. These exclusions limited the scope of analysis to 2 Aichi targets, 8 global and 10 different EU policy indicators with potential relevance to NFIs because they might be measureable in forests (cf. all tables presented in results section, i.e. Tables 36-39). 


\subsection{Relevance (Q1)}

\subsubsection{UN-Target 5: Reducing loss of natural habitats and forest areas}

Based on the abovementioned analysis of reports, the following section describes and compares data requirements of the European and the global reporting authorities when measuring achievement of the $5^{\text {th }}$ target of the CBD: to "at least halve [...] the rate of loss of natural habitats, including forests". A comparison of Table 36 and Table 37 shows that both, the global (Table 36) and the European report (Table 37) assessed the target by similar indicators. Also quality requirements were comparable. In general, the variables described (1) the state and change of the extent of forest areas, (2) naturalness and (3) deforestation.

It is interesting to see that though NFIs generally produced much of such data at high levels of precision and accuracy, they were largely irrelevant when compared to other sources. Instead, most of the published evidence based on peer-reviewed research studies using large-area global or European data from satellite-based remote sensing and monitoring programmes of NASA, EEA and EC JRC (Table 36). This and the following observations provided an indication on quality requirements: First, the preference of global-scale over national-scale monitoring programmes showed a preference of internationally comparable, i.e. harmonized assessments. Another advantage of maps was generation of spatially explicit land covers classifications at a spatial resolution (e.g. $30 \mathrm{~m}$ in: Hansen, 2013). The NFI sampling, in contrast, is not designed to generate such maps with spatially explicit information. Finally, the usage of printed maps within the report pointed to illustrative or communicative advantages.

Table 36 shows another variable of high importance for global decision-makers and for the design of future inventory programmes. The variable was requested by the Ad Hoc Technical Expert Group on Indicators at its meeting in High Wycombe, 2011 (AHTEG, 2011) and it is listed under points 5 and 6 of Table 36: The required variable measures areas qualifying as "threatened" ecosystems under the global Red List Index and is provided by an famous environmental non-governmental organization (ENGO) for nature conservation, i.e. the "International Union for Nature Conservation (IUCN)". The index is still under development and generally seeks to assess the risks to ecosystems and their functioning (Rodriguez et al., 2015). According to a methodology proposed by Keith et al. (2013) the index will use input variables such as distribution of ecosystems and the alteration of their biotic and abiotic variables. The output then measures the risk of global collapse using a scale ranging from least concern (LC), to Near Threatened (NT), Vulnerable (VU), Endangered (EN), Critically 
Endangered (CR) and Collapsed (CO). Among others, it will base on input variables such as rareness and threats. It is worthwhile noting that the international data administrator, i.e. the IUCN, has not named the relevant data providers and it remains questionable which of the national inventories is going to provide input variables. In Germany, there might be two possible providers, the BfN and its habitat mapping programmes and the NFI. BfN is a likely provider, because it is generally the responsible authority for communication with IUCN and it has already developed a national methodology for a "Red List on Endangered Habitats" (Ssymank et al., 1993; Rieken et al., 1994; Fink et al., 2017). The question is, if for fieldbased measurements, extension of cooperation between programmes of different resorts is feasible. Previous observations (Chapter 4) on cooperative monitoring efforts for reporting purposes on EU-habitats indicated that such cooperation could be principally possible if definitions and methods are amended accordingly. At least, EU-habitats identified by the NFI under reporting obligations of the Habitats Directive might indicate or stratify areas that potentially qualify as red-listed habitats under IUCN. 
Table 36. Global requirements for CBD-Aichi Target 5 "Reducing loss of natural habitats and forest areas". Requirements are indicated by data sources used in the $4^{\text {th }}$ Global Biodiversity Outlook report

\begin{tabular}{|c|c|c|c|c|}
\hline \multicolumn{3}{|c|}{$\begin{array}{l}\text { Target 5: By } 2020, \text { the rate of loss of all natural hab } \\
\text { close to zero, and degradation and fragmentation is } \\
\text { Attribute }\end{array}$} & \multirow{2}{*}{$\begin{array}{l}\text { Quality } \\
\text { Method }\end{array}$} & \multirow{2}{*}{$\begin{array}{l}\text { Data providers } \\
\text { Providing authority covering European } \\
\text { forest data (according to GBO } 4 \text { technical } \\
\text { report) }\end{array}$} \\
\hline & $\begin{array}{l}\text { Operational } \\
\text { Indicator (CBD) } \\
\text { relevant in Europe's } \\
\text { forests }\end{array}$ & $\begin{array}{l}\text { Input variables and } \\
\text { measurement units }\end{array}$ & & \\
\hline \multirow[t]{2}{*}{01} & \multirow[t]{2}{*}{$\begin{array}{l}\text { Trends in extent of } \\
\text { selected biomes, } \\
\text { ecosystems and } \\
\text { habitats (decision } \\
\text { VII/30 and VIII/15) }\end{array}$} & $\begin{array}{l}5 \text { land cover classes } \\
\text { in ha }\end{array}$ & $\begin{array}{l}\text { Remote sensing, global } \\
\text { land cover data sets } \\
\text { and ground } \\
\text { measurements }\end{array}$ & $\begin{array}{l}\text { Hansen MC, Potapov PV, Moore R et al. } \\
\text { (2013). High-resolution global maps of } 21 \text { st- } \\
\text { century forest cover change. Science, } 342 \text {, } \\
850-853 \text {. } \\
\text { FAOSTAT database partly based on NFI } \\
\text { data, } 2014\end{array}$ \\
\hline & & $\begin{array}{l}\text { IUCN Red List of } \\
\text { Ecosystems in ha } \\
\text { (under } \\
\text { development) }\end{array}$ & - To be defined - & - To be defined - \\
\hline 02 & $\begin{array}{l}\text { Trends in } \\
\text { fragmentation of } \\
\text { natural habitats } \\
\text { (decision VII/30 and } \\
\text { VIII/15) }\end{array}$ & $\begin{array}{l}\text { Degraded (partially } \\
\text { deforested) areas in } \\
\text { ha }\end{array}$ & $\begin{array}{l}\text { Based on remote } \\
\text { sensing of forests } \\
\text { (MODIS 500, Landsat } \\
\text { TM, ETM+) }\end{array}$ & $\begin{array}{l}\text { Laestadius L, Minnemeyer S, Leach A (2012) } \\
\text { Assessment of Global Forest Degradation. } \\
\text { Washington D.C., World Resource Institute }\end{array}$ \\
\hline 03 & $\begin{array}{l}\text { Trends in primary } \\
\text { productivity of } \\
\text { natural habitats }\end{array}$ & $\begin{array}{l}\text { Land areas with } \\
\text { declining } \\
\text { Normalised } \\
\text { Difference } \\
\text { Vegetation Index } \\
\text { (NDVI) in ha } \\
\end{array}$ & $\begin{array}{l}\text { Remote sensing } \\
\text { (MODIS, GIMMS } \\
\text { dataset) }\end{array}$ & $\begin{array}{l}\text { Bai Z. G., D. L. Dent, L. Olsson, and } \\
\text { Schaepman, M.E. (2008). Proxy global } \\
\text { assessment of land degradation. Soil Use } \\
\text { Manag. 24, 223-234. }\end{array}$ \\
\hline 04 & $\begin{array}{l}\text { Trends in the } \\
\text { proportion of } \\
\text { natural habitats } \\
\text { converted }\end{array}$ & $\begin{array}{l}4 \text { forest status } \\
\text { classes in ha: } \\
\text { Deforested areas, } \\
\text { Degraded (partially } \\
\text { deforested), } \\
\text { Managed Forests, } \\
\text { Intact forest }\end{array}$ & $\begin{array}{l}\text { Remote sensing of } \\
\text { forests (MODIS 500, } \\
\text { Landsat TM, ETM+) }\end{array}$ & $\begin{array}{l}\text { Laestadius L, Minnemeyer S, Leach A (2012) } \\
\text { Assessment of Global Forest Degradation. } \\
\text { Washington D.C., World Resource Institute. }\end{array}$ \\
\hline 05 & $\begin{array}{l}\text { Trends in proportion } \\
\text { of degraded/ } \\
\text { threatened habitats }\end{array}$ & $\begin{array}{l}\text { IUCN Red List of } \\
\text { Ecosystems in ha } \\
\text { (under development }\end{array}$ & - To be defined - & - To be defined - \\
\hline 06 & $\begin{array}{l}\text { Trends in condition } \\
\text { and vulnerability of } \\
\text { ecosystems }\end{array}$ & $\begin{array}{l}\text { IUCN Red List of } \\
\text { Ecosystems in ha } \\
\text { (under development }\end{array}$ & - To be defined - & - To be defined - \\
\hline 07 & $\begin{array}{l}\text { Population trends of } \\
\text { habitat dependent } \\
\text { species in each } \\
\text { major habitat type }\end{array}$ & $\begin{array}{l}\text { Wild Bird Index } \\
\text { value }\end{array}$ & $\begin{array}{l}\text { Non-probabilistic field } \\
\text { sampling }\end{array}$ & BirdLife International /EBCC \\
\hline
\end{tabular}

\begin{tabular}{|c|c|}
\hline EBCC & European Bird Census Council (Non-Governmental Organization) \\
\hline ETM+ & Enhanced Thematic Mapper of the Landsat 7 satellite at $15-30 \mathrm{~m}$ resolution, made available through NASA \\
\hline GIMMS & $\begin{array}{l}\text { Global Inventory Modeling and Mapping Studies data in } 8 \mathrm{~km} \text { resolution derived from imagery obtained from the } \\
\text { Advanced Very High Resolution Radiometer (AVHRR) instrument onboard the National Oceanic and Atmospheric } \\
\text { Administration (NOAA) satellites } 7,9,11,14,16 \text {, and 17, made available through NASA }\end{array}$ \\
\hline IUCN & International Union for Conservation of Nature (Non-Governmental Organization) \\
\hline MODIS & $\begin{array}{l}\text { Moderate Resolution Imaging Spectroradiometer at } 250 \text { - } 500 \mathrm{~m} \text { resolution onboard Terra satellite made available } \\
\text { through NASA }\end{array}$ \\
\hline NDVI & Normalised Difference Vegetation Index \\
\hline
\end{tabular}


Table 37. European data requirements for CBD-Aichi Target 5 "Reducing loss of natural habitats and forest areas". Requirements are indicated by data sources used in the EU report.

\begin{tabular}{|c|c|c|c|c|c|c|c|c|}
\hline \multicolumn{4}{|c|}{ Attribute } & \multirow{3}{*}{$\begin{array}{l}\text { Quality } \\
\text { Method }\end{array}$} & \multicolumn{4}{|l|}{ Data providers } \\
\hline \multicolumn{3}{|c|}{ EU SEBI indicators with ID } & \multirow{2}{*}{$\begin{array}{l}\text { Input variables and measurement } \\
\text { units }\end{array}$} & & \multirow{2}{*}{$\begin{array}{l}\text { EU data } \\
\text { management }\end{array}$} & \multicolumn{3}{|c|}{ Inventory authority } \\
\hline & & & & & & $\mathrm{DE}$ & SE & PL \\
\hline 04: & \multicolumn{2}{|c|}{$\begin{array}{l}\text { Ecosystem coverage } \\
\text { (including forest } \\
\text { areas) }\end{array}$} & $\begin{array}{l}\text { Area change (ha) of } 12 \text { land cover } \\
\text { classes 2000-2006 }\end{array}$ & $\begin{array}{l}\text { Remote } \\
\text { sensing (CLC) }\end{array}$ & EEA & \multicolumn{3}{|l|}{ EC JRC } \\
\hline 05: & \multicolumn{2}{|c|}{$\begin{array}{l}\text { Conservation status } \\
\text { of habitats of } \\
\text { European interest }\end{array}$} & $\begin{array}{l}\% \text { conservation status categories } \\
\text { based on areas and structural } \\
\text { variables }\end{array}$ & $\begin{array}{l}\text { Probabilistic } \\
\text { and non- } \\
\text { probabilistic } \\
\text { sampling }\end{array}$ & DG ENV, EEA & $\begin{array}{l}\mathrm{BfN} \\
\text { and } \\
\text { states, } \\
\text { BMEL } \\
(\mathrm{NFI})\end{array}$ & $\begin{array}{l}\text { SLU } \\
(\mathrm{NFI})\end{array}$ & GIOS \\
\hline \multirow[t]{10}{*}{ 13: } & $\begin{array}{l}\text { Fragmen } \\
\text { natural s } \\
\text { areas }\end{array}$ & $\begin{array}{l}\text { tion of } \\
\text { ni-natural }\end{array}$ & $\begin{array}{l}\text { Proportion loss (ha) in the time } \\
\text { period of } 2000-2006 \text { of "core } \\
\text { natural" landscapes within } 4 \text { size } \\
\text { classes of areas }\end{array}$ & $\begin{array}{l}\text { Remote } \\
\text { sensing (CLC) }\end{array}$ & EEA & EC JRC & & \\
\hline & \multicolumn{8}{|c|}{ Acronyms and description: } \\
\hline & BMEL & \multicolumn{7}{|c|}{ German Federal Ministry for Food and Agriculture } \\
\hline & CLC & \multicolumn{7}{|c|}{$\begin{array}{l}\text { CORINE Land Cover } 2000 \text { and } 2006 \text { Database, land-use classes provided at minimum mapping unit } 25 \text { ha and minimum } \\
\text { mapping width } 100 \mathrm{~m} \text {, based on Landsat } 7 \text { ETM pixel size } 15-30 \mathrm{~m}\end{array}$} \\
\hline & DG ENV & \multicolumn{7}{|c|}{ Directorate-General for Environment (decision-making institution of the European Union) } \\
\hline & EEA & \multicolumn{7}{|c|}{ European Environment Agency (Governmental Agency) } \\
\hline & EC JRC & \multicolumn{7}{|c|}{ European Commission Joint Research Centre (Governmental research institute) } \\
\hline & GIOS & \multirow{2}{*}{\multicolumn{7}{|c|}{ Inspectorate of Environmental Protection (Governmental Agency) }} \\
\hline & SEBI & \multicolumn{3}{|c|}{ Streamlining European Biodiversity Indicators (EU indicator development programme) } & & & & \\
\hline & SLU & \multicolumn{7}{|c|}{ Swedish University of Agricultural Sciences (independent research institute) } \\
\hline
\end{tabular}

\subsubsection{UN-Target 7: Sustainable forest management}

For reporting purposes to the other target on forestry, the CBD Aichi target 7 "sustainable forest management", the global and the European reporting authorities selected different definitions, attributes and quality requirements. The global report assumed that areas certified by FSC or PEFC are managed sustainably (Table 38), and primarily uses such records to measure achievement towards global biodiversity objectives. Interestingly, even though, officially, the report also accepted the FAO/UNFF "seven thematic elements of sustainable forest management" (cf. Annex IV) as a definition for sustainable forest management, it used the FAO indicators, and partially case-studies, only as side-information to explain progress towards the 2020 target. The absence of a more rigorous use of indicators such as better availability of "growing stock" (FAO FRA ID 1.2), "deadwood" (ID 4.5) and "threatened forest species" (ID 4.8), means that the success of certification schemes was difficult to evaluate. Instead, as shown before in Box 11, the report primarily used the variable "areas certified under FSC and PEFC". Based on that information, the report then assumed that 
management practices of FSC and PEFC automatically result in "sustainable" conditions on forest areas.

This was different in the European report, which adopted a more outcome-focused approach. Rather than simply recording certified areas or management practices, it also measured possible effects and biodiversity gains. Table 39 lists the relevant indicators like deadwood stocks, conservation status, species abundance and fragmentation of natural areas. These variables measured desired effects of management practices and thus illustrated the outcomeoriented understanding of sustainable forest management (SFM) in Europe.

A comparison of Tables 38 and 39 shows that the differences of European and global definitions of indicators also resulted in a different choice of data sources and providers. While the global report referred primarily to absolute figures on areas managed sustainably, the European report assessed indicators that allow conclusions on the extent of biodiversitygain. The reason why European and global reporting authorities preferred different variables and data sources probably lies within the respective policy targets. The global policy target is to achieve SFM on all managed areas. This requires an area-specific assessment. The European policy target in contrast wants to achieve a qualitative improvement of the conservation status (target 3B). This target requires a qualitative assessment of several variables.

While NFI was used for measuring qualitative biodiversity gain of forest management practices in Europe, it was less relevant for the area-specific assessments within the global report. The disadvantage of NFIs and a possible explanation why inventories with probability sampling have not been used for that purpose is the inventory design itself: NFIs are often designed to answer national questions and results are difficult to compare on an international level. Furthermore, due to its focus on large-area estimation rather than mapping, NFI has limitations in generating classifications with spatially explicit information such as the location of forest edges. Originally, the provision of such information has not been defined as a primary goal of the German NFI because historically (cf. Chapter 1), its primary purpose was to generate information on forest resources for the forestry sector, a purpose which has been later extended to forests' contribution to climate-change mitigation under UNFCCC and Kyoto Protocol reporting obligations. For both purposes, it was generally sufficient to provide absolute estimates for a specific area (e.g. national growing stock, national above-ground carbon sinks). The provision of data for biodiversity assessments, in contrast, which need more spatially explicit information such as on the geographic location of forest edges, has not 
been defined as an original goal of the NFI. It was probably due to these limitations why reporting authorities chose data from alternative sources, such as the remote-sensing-based CORINE Land Cover Database from EEA.

Another disadvantage of the NFI that possibly led to the observed preference of alternative sources was a relatively low inclusion probability of rare events. A similarly fundamental, problem of the NFI was to observe dynamic events such as occurrence and abundance of mobile species. For reporting purposes, variables that were rare or that occurred only occasionally, were therefore observed by non-probabilistic techniques, for instance by inventorying areas with known or "potential" occurrence of selected species (Table 39). The species of the Red List (Ludwig et al, 2009) and habitats of European interest (Sachteleben and Behrens, 2010a) are examples for variables that were measured by such non-probabilistic approaches. These programs maximized inclusion probability, but, as I have already shown in Chapter 4 , they were not always based on a rigorous probability-based inventory designs, and in some of the German case studies, there is an indication that State programmes did not always comply to statistical rules of independent selection.

Table 38. Global requirements for CBD-Aichi Target 7 "Sustainable forest management" (SFM). Requirements are indicated by data sources used in the $4^{\text {th }}$ Global Biodiversity Outlook report.

\begin{tabular}{|c|c|c|c|c|}
\hline \multicolumn{3}{|c|}{ Q1: Attribute (official terminology) } & \multirow{2}{*}{$\begin{array}{l}\text { Q2: Quality } \\
\text { Method }\end{array}$} & \multirow{2}{*}{$\begin{array}{l}\text { Q3: Data providers } \\
\text { Providing authority covering } \\
\text { European forest data (according } \\
\text { to GBO } 4 \text { technical report) }\end{array}$} \\
\hline & $\begin{array}{l}\text { Operational Indicator (CBD) relevant in } \\
\text { Europe's forests }\end{array}$ & $\begin{array}{l}\text { Measurement } \\
\text { units }\end{array}$ & & \\
\hline 08 & $\begin{array}{l}\text { Trends in area of forest, agricultural and } \\
\text { aquaculture ecosystems under } \\
\text { sustainable management (B) (decision } \\
\text { VII/30 and VIII/15) }\end{array}$ & ha & $\begin{array}{l}\text { Cadastral information } \\
\text { without sampling }\end{array}$ & $\begin{array}{l}\text { Certification authorities FSC, } \\
\text { PEFC }\end{array}$ \\
\hline \multicolumn{5}{|c|}{ Acronyms and description: } \\
\hline & \multicolumn{4}{|c|}{ Forest Stewardship Council (Non-Governmental Organisation) } \\
\hline
\end{tabular}


Table 39. European data requirements for CBD-Aichi Target 7 "Sustainable forest management"(SFM). Requirements are indicated by data sources used in the EU report.

\begin{tabular}{|c|c|c|c|c|c|c|c|c|}
\hline \multicolumn{3}{|c|}{$\begin{array}{l}\text { Target 7: By } 2020 \text { areas under a } \\
\text { biodiversity. } \\
\text { Attribute (official terminology) }\end{array}$} & & Quality & \multicolumn{4}{|l|}{ Data providers } \\
\hline \multirow{2}{*}{\multicolumn{3}{|c|}{ EU SEBI indicators with ID }} & \multirow{4}{*}{$\begin{array}{l}\text { Measurement units } \\
\text { Population index (relative } \\
\text { values of abundance } \\
\text { compared to year 1990) }\end{array}$} & \multirow{4}{*}{$\begin{array}{l}\text { Method } \\
\text { Non- } \\
\text { probabilistic } \\
\text { sampling }\end{array}$} & \multirow{2}{*}{$\begin{array}{l}\text { EU data } \\
\text { management }\end{array}$} & \multicolumn{3}{|c|}{ Inventory authority } \\
\hline & & & & & & $\mathrm{DE}$ & SE & $\mathrm{PL}$ \\
\hline \multirow[t]{2}{*}{ 01: } & \multirow{2}{*}{\multicolumn{2}{|c|}{$\begin{array}{l}\text { Abundance and } \\
\text { distribution of } \\
\text { selected species }\end{array}$}} & & & \multirow[t]{2}{*}{ EBCC, BCE } & $\begin{array}{l}\text { UFZ, } \\
\text { NABU }\end{array}$ & HIG & TOM \\
\hline & & & & & & \multicolumn{3}{|l|}{ EBCC } \\
\hline 02: & \multicolumn{2}{|c|}{$\begin{array}{l}\text { Red List Index for } \\
\text { European species }\end{array}$} & $\begin{array}{l}\text { Change-index of species } \\
\text { abundance (1994-2004) }\end{array}$ & $\begin{array}{l}\text { Non- } \\
\text { probabilistic } \\
\text { sampling }\end{array}$ & $\begin{array}{l}\text { BirdLife } \\
\text { International }\end{array}$ & NABU & SOF & OTOP \\
\hline 03: & \multicolumn{2}{|c|}{$\begin{array}{l}\text { Conservation status } \\
\text { of species of } \\
\text { European interest }\end{array}$} & $\begin{array}{l}\text { \% conservation status } \\
\text { categories based on species } \\
\text { abundance }\end{array}$ & $\begin{array}{l}\text { Non- } \\
\text { probabilistic } \\
\text { sampling }\end{array}$ & DG ENV & $\begin{array}{l}\text { BfN } \\
\text { and } \\
\text { states }\end{array}$ & $\begin{array}{l}\text { SLU } \\
\text { (NFI) }\end{array}$ & GIOS \\
\hline 04: & \multicolumn{2}{|c|}{$\begin{array}{l}\text { Ecosystem coverage } \\
\text { (including forest } \\
\text { areas) }\end{array}$} & $\begin{array}{l}\text { Area change (ha) of } 12 \text { Land } \\
\text { cover classes 2000-2006 }\end{array}$ & $\begin{array}{l}\text { Remote } \\
\text { sensing } \\
(\mathrm{CLC})\end{array}$ & EEA & \multicolumn{3}{|l|}{ EC JRC } \\
\hline 05: & \multicolumn{2}{|c|}{$\begin{array}{l}\text { Conservation status } \\
\text { of habitats of } \\
\text { European interest }\end{array}$} & $\begin{array}{l}\text { \% conservation status } \\
\text { categories based on areas } \\
\text { and structural variables }\end{array}$ & $\begin{array}{l}\text { Probabilistic } \\
\text { and non- } \\
\text { probabilistic } \\
\text { sampling }\end{array}$ & DG ENV, EEA & $\begin{array}{l}\text { BfN } \\
\text { and } \\
\text { states, } \\
\text { BMEL } \\
\text { (NFI) }\end{array}$ & $\begin{array}{l}\text { SLU } \\
(\mathrm{NFI})\end{array}$ & GIOS \\
\hline 07: & \multicolumn{2}{|c|}{$\begin{array}{l}\text { Nationally } \\
\text { designated } \\
\text { protected areas }\end{array}$} & $\begin{array}{l}\text { Area }\left(\mathrm{km}^{2}\right) \\
\text { Number of sites }(\mathrm{N})\end{array}$ & $\begin{array}{l}\text { Cadastral } \\
\text { information } \\
\text { without } \\
\text { sampling }\end{array}$ & EEA & $\begin{array}{l}\text { BfN } \\
\text { and } \\
\text { states }\end{array}$ & SEPA & GIOS \\
\hline 08: & \multicolumn{2}{|c|}{$\begin{array}{l}\text { Sites designated } \\
\text { under EU Habitats } \\
\text { and Birds Directive }\end{array}$} & Area $\left(\mathrm{km}^{2}\right)$ & $\begin{array}{l}\text { Cadastral } \\
\text { information } \\
\text { without } \\
\text { sampling }\end{array}$ & DG ENV, EEA & $\begin{array}{l}\text { BfN } \\
\text { and } \\
\text { states }\end{array}$ & SEPA & GDOS \\
\hline 13: & \multicolumn{2}{|c|}{$\begin{array}{l}\text { Fragmentation of } \\
\text { natural and semi- } \\
\text { natural areas }\end{array}$} & $\begin{array}{l}\text { Proportion loss (ha) in the } \\
\text { time period of } 2000-2006 \text { of } \\
\text { "core natural" landscapes } \\
\text { within } 4 \text { size classes of areas }\end{array}$ & $\begin{array}{l}\text { Remote } \\
\text { sensing } \\
(\mathrm{CLC})\end{array}$ & EEA & \multicolumn{3}{|l|}{ EC JRC } \\
\hline 17: & \multicolumn{2}{|c|}{$\begin{array}{l}\text { Forest growing } \\
\text { stock, increment } \\
\text { and fellings }\end{array}$} & $\begin{array}{l}\text { Status: } \mathrm{m} 3 / \mathrm{ha} \\
\text { Changes: } \mathrm{m} 3 / \mathrm{ha} / \mathrm{yr}\end{array}$ & $\begin{array}{l}\text { Probabilistic } \\
\text { sampling }\end{array}$ & Forest Europe & $\begin{array}{l}\text { BMEL } \\
\text { (NFI) }\end{array}$ & $\begin{array}{l}\text { SLU } \\
\text { (NFI) }\end{array}$ & $\begin{array}{l}\text { BMFG } \\
\text { (NFI) }\end{array}$ \\
\hline 18: & \multicolumn{2}{|c|}{ Forest: deadwood } & $\begin{array}{l}\text { Status: } \mathrm{m} 3 / \mathrm{ha} \\
\text { Changes: } \mathrm{m} 3 / \mathrm{ha} / \mathrm{yr}\end{array}$ & $\begin{array}{l}\text { Probabilistic } \\
\text { sampling }\end{array}$ & Forest Europe & $\begin{array}{l}\mathrm{BMEL} \\
\text { (NFI) }\end{array}$ & $\begin{array}{l}\text { SLU } \\
\text { (NFI) }\end{array}$ & $\begin{array}{l}\mathrm{BMFG} \\
\text { (NFI) }\end{array}$ \\
\hline & \multicolumn{8}{|c|}{ Acronyms and description: } \\
\hline & EC JRC & \multirow{2}{*}{\multicolumn{7}{|c|}{$\begin{array}{l}\text { European Commission Joint Research Centre (Governmen } \\
\text { European Bird Census Council (Non-Governmental Organi }\end{array}$}} \\
\hline & European Bird Census Council (Non-Government & & & \multicolumn{2}{|c|}{ litesearch institute) } & & & \\
\hline & EEA & European $\mathrm{E}$ & vironment Agency (Governmental Ag & & & & & \\
\hline & BCE & & sservation Europe (Non-Governmenta & Organization) & & & & \\
\hline & BMEL & Federal Mir & stry for Food and Agriculture & & & & & \\
\hline & BMFG & Bureau of $F$ & rest Management and Geodesy (stat & wned commercia & company) & & & \\
\hline & $\mathrm{BfN}$ & Federal Age & cy for Nature Conservation (Governn & tal Agency) & & & & \\
\hline & CLC & $\begin{array}{l}\text { CORINE Lar } \\
\text { mapping } w\end{array}$ & $\begin{array}{l}\text { Cover } 2000 \text { and } 2006 \text { Database, lanc } \\
\text { th } 100 \mathrm{~m} \text {, based on Landsat } 7 \text { ETM pi }\end{array}$ & $\begin{array}{l}\text { se classes provide } \\
\text { size } 15-30 \mathrm{~m}\end{array}$ & at minimum mapp & g unit 2 & and $\mathrm{mi}$ & \\
\hline & DG ENV & Directorate & General for Environment (decision ma & $\mathrm{ng}$ institution of $\mathrm{tr}$ & European Union) & & & \\
\hline & EEA & European $\mathrm{E}$ & vironment Agency (Governmental Ag & & & & & \\
\hline & $\mathrm{FE}$ & Forest Euro & e (Ministerial Conference, political fo & $\mathrm{m}$ of European $\mathrm{Mi}$ & isters on forestry) & & & \\
\hline & GIOS & Inspectorat & of Environmental Protection (Govern & ental Agency) & & & & \\
\hline & GDOS & Generalna & yrekcja Ochrony Środowiska (General & rectorate of Envir & nmental Protection & & & \\
\hline & HIG & University & Gävle (independent research institut & & & & & \\
\hline & NABU & Nature And & Biodiversity Conservation Union (Non & overnmental Orga & isation) & & & \\
\hline & $\mathrm{NFI}$ & National Fo & est Inventory & & & & & \\
\hline & ОTOP & Polish Socie & $y$ for the Protection of Birds (Non-Go) & nmental Orgar & ion) & & & \\
\hline & SEBI & Streamlinin & European Biodiversity Indicators (EU & dicator developm & te programme) & & & \\
\hline & SEPA & Swedish En & ironmental Protection Agency & & & & & \\
\hline & SOF & Swedish Or & ithological Society (SOF) (Non-Govern & ental Organizatior & & & & \\
\hline & SLU & Swedish Un & versity of Agricultural Sciences (indep & dent research ins & cute) & & & \\
\hline & TOM & Polish Asso & ation for Butterfly Conservation (Non & overnmental Org & hisation) & & & \\
\hline & UFZ & Helmholtz & entre for Environmental Research (inc & sendent research & stitute) & & & \\
\hline
\end{tabular}




\subsection{Risk of political bias (Q2)}

While the previous section had answered the question of data requirements, this section aims to assess the risk of political bias. For this purpose my analysis validated two assumptions of the political theory (in Ch.1.3: Krott, 2012; Krott et al., 2014; Pregernig, 2007; Hertin et al., 2009; Haas, 2004; Pielke, 2007): 1) political motivations and 2) non-transparent assessment methods. In this context, European and global reporting authorities, their political motivations and the non-transparency of their reporting methods are the focus of this part of study.

Regarding political motivations, it must be borne in mind that the EC's Directorate General of Environment and the secretariat of CBD do not only have reporting obligations, but they are also involved in political settings where they co-define international forest policy. Their motivational backgrounds for running inventory programmes are therefore identical with the targets defined by their respective policies, which were generally:

In Europe: A "measureable improvement in the conservation status of species and habitats" (target 3B in: European Biodiversity Strategy COM 2011/244 and in: EU Habitats Directive/ Council Directive 92/43/EEC)

Globally: To at least half the loss of natural habitats and to reduce their fragmentation and degradation (Aichi target 5 in: Global Strategic Plan for Biodiversity/ CBD COP decision $\mathrm{X} / 2$ )

In the previous section (Ch. 5.4), we have already observed that these motivations influenced data choice in very different ways. But Tables 40 and 41 show that there was little evidence for us to conclude that they implicitly biased the reported values. The reason is that all data sources and assessment methods were documented and provided no evident options for the EU or UN to hide unwanted information or to bias results in different ways. The overall transparency of the European and global reporting methods guaranteed verifiability and scientific credibility. Yet, in analysis of national reporting processes in Chapter 4, we have seen that authorities involved at the lower levels of the data generation process may still implicitly influence data such as to serve their individual political needs. Then however, the source of a risk of political bias is the national provider, not the EC- or the UN- authorities. 
Table 40. Risk of political bias in European and global reports to UN-target 5. The table describes risk of political bias as a function of political motivations and non-transparent reporting methods of data providers. Political motivations are described by the targets of the provider's policies (UN policy: global Strategic Plan for Biodiversity CBD COP decision X/2; EU policy: European Biodiversity Strategy COM 2011/244)

\begin{tabular}{|c|c|c|c|c|}
\hline \multirow{3}{*}{ Providers } & \multicolumn{2}{|c|}{ Q 1 Relevance } & \multicolumn{2}{|c|}{$\begin{array}{l}\text { Q } 2 \text { Risk of political bias } \\
\text { (confirmed under } 2 \text { conditions) }\end{array}$} \\
\hline & ID & $\begin{array}{l}\text { Attribute } \\
\text { (value reported to UN, official terminology) }\end{array}$ & $\begin{array}{l}\text { Non- } \\
\text { transparency }\end{array}$ & Political motivation \\
\hline & & & $\begin{array}{l}\text { Value without } \\
\text { reference }\end{array}$ & Policy target of provider \\
\hline UN & $\begin{array}{l}01 \\
02 \\
03 \\
04 \\
05 \\
06 \\
07\end{array}$ & $\begin{array}{l}\text { Trends in extent of selected biomes, } \\
\text { ecosystems and habitats (decision VII/30 and } \\
\text { VIII/15) } \\
\text { Trends in fragmentation of natural habitats } \\
\text { (decision VII/30 and VIII/15) } \\
\text { Trends in primary productivity of natural } \\
\text { habitats } \\
\text { Trends in the proportion of natural habitats } \\
\text { converted } \\
\text { Trends in proportion of degraded/ threatened } \\
\text { habitats } \\
\text { Trends in condition and vulnerability of } \\
\text { ecosystems } \\
\text { Population trends of habitat dependent species } \\
\text { in each major habitat type }\end{array}$ & $\begin{array}{l}- \\
- \\
- \\
- \\
- \\
- \\
- \\
- \\
-\end{array}$ & $\begin{array}{l}\text { UN target } 5 \\
\text { "By } 2020 \text {, the rate of loss of all } \\
\text { natural habitats, including } \\
\text { forests, is at least halved and } \\
\text { where feasible brought close to } \\
\text { zero, and degradation and } \\
\text { fragmentation is significantly } \\
\text { reduced." }\end{array}$ \\
\hline EU & $\begin{array}{l}04 \\
05 \\
13\end{array}$ & $\begin{array}{l}\text { Ecosystem coverage (including forest areas) } \\
\text { Conservation status of habitats of European } \\
\text { interest } \\
\text { Fragmentation of natural and semi-natural } \\
\text { areas }\end{array}$ & - & $\begin{array}{l}\text { EC target 3B } \\
\text { "By 2020, Forest Management } \\
\text { Plans or equivalent instruments } \\
\text { [...] are in place [...] so as to } \\
\text { bring about a measurable } \\
\text { improvement in the } \\
\text { conservation status of species } \\
\text { and habitats [...] as compared } \\
\text { to the EU } 2010 \text { Baseline." }\end{array}$ \\
\hline
\end{tabular}


Table 41. Risk of political bias in European and global reports to UN-target 7. The table describes risk of political bias as a function of political motivations and non-transparent reporting methods of data providers. Political motivations are described by the targets of the provider's policies (UN policy: global Strategic Plan for Biodiversity CBD COP decision X/2; EU policy: European Biodiversity Strategy COM 2011/244)

\begin{tabular}{|c|c|c|c|c|}
\hline & \multicolumn{2}{|c|}{ Q 1 Relevance } & \multicolumn{2}{|c|}{$\begin{array}{l}\text { Q } 2 \text { Risk of political bias } \\
\text { (confirmed under } 2 \text { conditions) }\end{array}$} \\
\hline \multirow[t]{2}{*}{ Providers } & \multirow[t]{2}{*}{ ID } & \multirow[t]{2}{*}{$\begin{array}{l}\text { Attribute } \\
\text { (value reported to UN official terminology) }\end{array}$} & $\begin{array}{l}\text { Non-trans- } \\
\text { parency }\end{array}$ & Political motivation \\
\hline & & & $\begin{array}{l}\text { Value } \\
\text { without } \\
\text { reference }\end{array}$ & Evident from policy target \\
\hline UN & 08 & $\begin{array}{l}\text { Trends in area of forest, agricultural and aquaculture } \\
\text { ecosystems under sustainable management (B) } \\
\text { (decision VII/30 and VIII/15) }\end{array}$ & - & $\begin{array}{l}\text { UN target } 7 \\
\text { "By } 2020 \text { areas under } \\
\text { agriculture, aquaculture and } \\
\text { forestry are managed } \\
\text { sustainably, ensuring } \\
\text { conservation of biodiversity." }\end{array}$ \\
\hline EU & $\begin{array}{l}01 \\
02 \\
03 \\
04 \\
05 \\
07 \\
08 \\
13 \\
17 \\
18\end{array}$ & $\begin{array}{l}\text { Abundance and distribution of selected species } \\
\text { Red List Index for European species } \\
\text { Conservation status of species of European interest } \\
\text { Ecosystem coverage } \\
\text { Conservation status of habitats of European interest } \\
\text { Nationally designated protected areas } \\
\text { Sites designated under EU Habitats and Birds Directive } \\
\text { Fragmentation of natural and semi-natural areas } \\
\text { Forest growing stock, increment and fellings } \\
\text { Forest: deadwood }\end{array}$ & $\begin{array}{l}- \\
- \\
- \\
- \\
- \\
- \\
- \\
- \\
- \\
- \\
-\end{array}$ & $\begin{array}{l}\text { EC target 3B } \\
\text { "By 2020, Forest Management } \\
\text { Plans or equivalent instruments } \\
{[\ldots] \text { are in place [...] so as to }} \\
\text { bring about a measurable } \\
\text { improvement in the } \\
\text { conservation status of species } \\
\text { and habitats [...] as compared to } \\
\text { the EU } 2010 \text { Baseline." }\end{array}$ \\
\hline
\end{tabular}

\subsection{Conclusion}

By the above analyses, I wanted to contribute to answering 2 research questions: (Q1) the political relevance of forest data, and $(\mathrm{Q} 2)$ the risk of political bias within data provided to European and global biodiversity reports. Addressing Q2, I explained that though policy targets influenced data choice, the reporting process guaranteed verifiability and left no obvious option for political motivations to hide unwanted evidence or to bias assessment results in other ways. Instead, the providers cited all sources and comprehensively explained the methods of report compilation.

The key-reports of the EC and the UN, their referenced attributes, statistical qualities and their data providers then answered research question Q1: "data relevance". Results showed a high 
demand for attributes such as 1) forest area, 2) naturalness in terms of human disturbance and 3) sustainable forest management (SFM). Nevertheless, the global and the European interpretations were quite different and the choice of attributes often depended on the political settings and the respective data providers:

The EU adapted definitions from its biodiversity policy, the Habitats Directive. Definitions of politically required and consulted attributes such as "conservation status" were therefore in line with those of existing monitoring programmes of EC JRC and DG Environment. Whereas, the Conference of the Parties to the Convention on Biological Diversity (the UN's COP of the CBD) has defined targets based on recommendations of NGOs who had been involved in biodiversity policy at a very early stage of the set-up of CBD (Raustialia, 1997). IUCN thus drafted the first text of the CBD and established the Red List of threatened species as a guideline to evaluate policy achievement. Accordingly, UN targets were often compatible to those of ENGOs and their established monitoring programmes. It was probably for this reason, why the UN largely relied on existing inventory programmes. This observation indicates that for a data provider to become politically relevant, he needs to establish a political relationship of trust and engage in political discussions and help to co-define political questions.

Scientific validity, as well, was an important criterion for political relevance of data providers: In fact, policy-makers valued independent scientific work that had been verified and approved by peer review. Examples are studies on mapping global forest cover (Hansen et al., 2013), and natural habitats (Laestadius et al., 2012). Such findings showed that political cooperation and scientific independence are not mutually exclusive.

Next to the abovementioned ability of inventoried attributes to answer policy questions and the established trust in the respective data providers, data quality, i.e. the inventory method, was the third important criterion for policy makers to select a specific source of information. It is interesting to observe that remote sensing programmes were generally preferred over approaches that base on rigorous statistical sampling. One advantage of remote sensing programs was certainly the coverage of multiple types of land-use, beyond forest boarders. Inventories based on statistical principles, such as NFIs, in contrast focus on forests and generally do not provide information on the wider landscape (with Sweden being an exception). On top of that, forest inventories are generally administered on a national-, not on a European or global level. This implies that national forest estimates vary according to the respective national definitions (as shown by COST Action 43; cf. 
www.metla.fi/eu/cost/e43/)). Both, varying definitions in NFIs and their constrained focus on a single land-use category, may be possible explanations why European and global reporting authorities preferred or trusted data more when it was provided centrally, either through EEA/EC-JRC, or globally through the global tree cover map provided by Hansen et al. (2013), even if data quality and comparability of classifications were not readily evident from provided maps.

Another possible reason for the preference of data provided through remote sensing programmes is their ability to provide maps with spatially more explicit information. This information possibly had advantages because it allowed the reader to draw conclusion on the location and fragmentation of forest edges.

Finally, one additional explanation for the preference of maps over NFI information might be the format. We could, at least, assume that maps are more easily understood by non-technical readers and policy-makers, especially because maps are very common, also outside the scientific world. In a similar context, cognitive science speaks of the "picture superiority effect". This effect describes a learning mechanism where pictures are more easily memorised than words (Hockley, 2008; Defeyter et al., 2009; Curran and Doyle, 2011), possibly because pictures trigger emotion, something that is essential for learning (Kensinger, 2007; Phelps, 2004). Though I am not aware of any study that had studied the picture superiority effect when memorising numbers such those describing the spatial extend of forest areas, we can at least assume that a map displaying deforestation in relation to the full spatial extend of countries triggers emotion and memory more easily than a simple table filled with numbers.

One final interesting observation with respect to the quality of data sources is the frequent usage of techniques without rigorously standardised sampling approaches (statistical sampling following a transparently defined and documented protocol). Especially the assessments of species for the Red Lists did not provide any evidence on a clearly defined and unambiguous sampling approach (cf. Red List methodology in: Rodriguez et al.; 2006 and Rodriguez et al., 2015; Ludwig et al, 2009). Similarly, also Chapter 4 explained that sampling under Habitats Directive could not always guarantee compliance with statistical principles. Instead, nonprobabilistic selection criteria such as steered sampling of areas where field teams suspected the occurrence of rare habitats, flora or fauna were more common. As for reporting under CBD, this shortcoming was probably not due to any tacit political motivation to hide or bias results, but it was more likely to be a necessity due to absence of alternative sources of evidence. In fact, non-probabilistic techniques were used primarily for assessment of rare or 
dynamic events, such as the occurrence of butterflies, birds and threatened habitat types. These attributes are generally difficult to measure at sufficient precision by means of statistical sampling where sample effort is generally limited by funds allocated to the inventory. Also the NFI protocols (cf. BMEL, TI, 2014) indicate that probability-based inventories are currently unable to provide such information. For this reason, reporting authorities had to choose alternative sources without a statistical design. These generally included non-random sampling and expert opinion which is most likely to lead to limitations when it comes to statistical analysis. The following section therefore looks at how these shortcomings may be addressed by cooperation and data exchange between different but complementary inventory programmes.

\subsection{Outlook on options to improving the inventory}

\subsubsection{Relationships and building trust}

Based on evidence of successful monitoring programmes, this section collects ideas on the possible improvement of NFIs. I will look at how statistical standards could be integrated with political requirements, and I will propose general research ideas for the development of future inventories.

First of all, previous analyses had found political trust to be an important criterion. Reporting authorities preferred those providers that had already contributed in the phase of formulating the policy objectives. If the objective is to gain political recognition, monitoring programmes could therefore extend trust by cooperation with the political community. Listening and understanding political needs may also reassure policy makers that their issues are properly understood and that urgent questions will be addressed by best possible means science has to offer. Similarly, Guldin (2003) showed that constant and personal communication and collaboration was important to establish trust and to actually get scientific messages across. Such cooperation could be initiated by collaboration with authorities that are already recognized providers in the political domain. According to my study, these might be the EEA, JRC, the Directorate General Environment of the EC or NGOs. At the same time, inventory specialists may continue to protect scientific credibility and the risk of being perceived as political advocates. An option to deter such perception is constant scientific discourse via publication of monitoring methods in peer-reviewed journals. The review process does not only contribute to validity but it fuels scientific discourse and enables further research on the improvement of methodologies. 


\subsubsection{Inventory design}

Beyond the need to investigate relationships of trust and scientific credibility, the characteristics of policy relevant data sources analysed in this chapter suggested a need for inventories 1) to illustrate results in maps, 2) to enhance comparability of national programmes, and 3) to implement new approaches to better capture rare events.

The reason for these observations is the fact that reporting authorities often preferred remotesensing programmes over sample-based NFI measurements. This was the case at least for the assessment of land-use and fragmentation. Thus, if the objective is to improve political relevance of NFIs, they may combine field assessments with ancillary data from remotesensing programmes. Those of the EU CORINE Land Cover project may be instrumental because the programme is already well-established in various international reporting processes, ranging from biodiversity reporting under CBD to carbon emission reporting under UNFCCC (Penman et al., 2003). Integration methods such as the k-nearest neighbour technique are already in use in Norway (Gjertsen, 2007) and Sweden (Reese, 2005; Hagner et al., 2005), where they allow inventory specialists to generate data of important variables at a higher spatial resolution, so-called small area estimations. The presentation of results in maps may further provide an easy-to-understand and illustrative overview of spatial information that is communicated more easily.

This study further indicated a substantial political demand for attributes with rare and occasional occurrences such as birds or other fauna. To increase inclusion probability, NGOs and national conservation agencies often assessed such variables by non-random methods and expert assessment. To address clashes with the statistical assumptions of independent selection, it might be instrumental to use NFI information as ancillary information to stratify areas with potential occurrence of habitat types. Existing NFI assessments of European habitat types might provide a useful starting point for such stratification efforts. To my knowledge no country or organisation has yet used NFI information as an ancillary input for the assessment and reporting of fauna diversity. Since habitat monitoring programmes and the German NFI have joined forces for reporting processes in 2013, such cooperation might be extended also for the assessment of Red-Lists and species of fauna

Another option is to look at biodiversity programmes that have already established inventories for the assessment fauna diversity. The United Kingdom (UK Breeding Bird Survey (BBS)) and New Zealand have experience with distance sampling (Newson et al., 2005; Buckland et 
al. 2001; Greene et al., 2012). Even though the countries do not yet integrate such assessments in NFI they might still provide valuable insights on the potential advantages of such methods such as accuracies attained for different kinds of variables and costs associated with extensive measurements.

Indeed, the biggest problem with assessment of fauna by means of probabilistic sampling is certainly the associated expenditures. Such assessments would require a vast amount of ancillary information and complex estimation because sampling and plot designs generally require adaptation to behavioural characteristics of the targeted species (Sollmann et al., 2016). A possible and easier option to limit such costs is stratification that directs monitoring effort towards sites with potential occurrences. In this endeavour, NFI assessments of EU forest habitats may provide useful information. Similarly, existing measurements on forest structures such as on habitat trees and dead-wood may indicate breeding and foraging sites, thus providing a starting-point for stratification efforts.

Further, options of limiting costs may be derived from reorganisation of field-work. The UK Breeding Bird Survey (BBS) for instance, limits expenditures by employing volunteers for measurements. Similar models of citizen science, i.e. inventories relying on volunteers, are already on the rise in many other countries (Tulloch et al., 2013). Observer-bias could however be an issue, especially because, volunteers generally do not have a professional training comparable to the expertise of full-time inventory specialists. The BBS addresses that issue by providing advice and clear and unambiguous guidance. A central administrative body and regional inventory organisers provide basic training, field protocols and direct volunteers to the appointed sample plots.

100 years of experience with bird monitoring in the UK further shows that volunteers were generally highly motivated (Battersby and Greenwood, 2004). Tulloch et al. (2013) add that volunteers seek to contribute to "real science". Similarly, Rees and Pond (1995) stress politically unbiased motives and state that "volunteers have no political, economic or personal motives for influencing the data collected which is therefore completely impartial" (Rees and Pond, 1995, p. 107). We may conclude that in spite of inherent complexity and various sources of bias, volunteer-based inventories of mobile species could have a real potential in filling data gaps that are too costly to assess by paid professionals. The prerequisite is of course, that field manuals are transparent and include precisely and clearly defined measurement rules. 


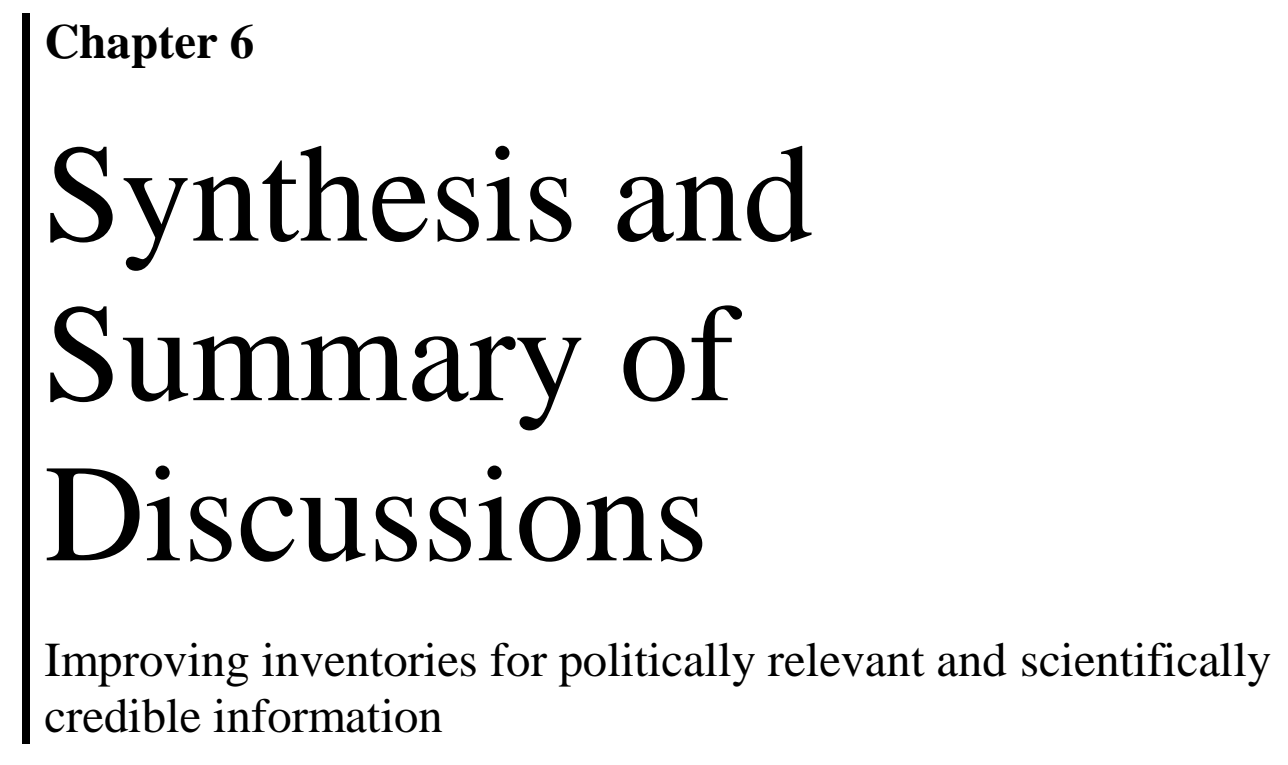




\subsection{General considerations}

In the previous chapters I have identified the various political discourses on SFM and legallybinding reporting processes that frame political data needs today. I have also elaborated the risks of hidden bias that may evolve from the political instrumentalisation of "scientific" data. This chapter will summarise and discuss the most important findings. I want to highlight that the objective is not to ascertain or prove anything by a specific degree of certainty, but to make inventory specialists aware of potential risks to scientific credibility that may evolve around the science-policy gap. To underline these constructive ambitions, the chapter at hand will conclude by a brief outlook on options of how inventory specialists and reporting authorises may better respond to political data needs while, at the same time, averting the risk of being perceived advocates of some hidden political agenda.

Essentially, the more recent discourse on binding SFM policies has started with the World Summit in Rio de Janeiro in 1992 (UNCED = United Nations Conference on Environment and Development). The conference was a milestone as it has initiated new agreements around legally binding management standards under the UNFF and extended the forest policy framework of existing legally-binding conventions such as CLRTAP (clean air) by additional sectoral agreements on biodiversity, land degradation and climate change via global and European agreements and policies under the UNCBD, UNCCD, UNFCCC and the Kyoto Protocol. These agreements come with a full range of reporting commitments that shall enable the generation of internationally comparable datasets and an equitable assessment of policyperformance at the global level. The European and national discussions and policies aim at the implementation of such global policies. Hence, the European Commission has issued regional reporting obligations, one of which comprises national biodiversity reports under the Habitats Directive, a topic that is fairly new to NFIs which have traditionally been more targeted towards the assessment of economically tradeable resources ${ }^{20}$.

My study has explained that in order to enforce related goals on the regulation of forest management and the implementation of legally binding standards under the UNFF, national parliaments have further demanded NFIs to extend their database in order to provide more comprehensive information on the diverse and changing questions of policy-making. The new information shall eventually measure and assess the national progress towards sustainable forest management, thus informing the national and international discourses and providing

\footnotetext{
${ }^{20}$ Examples: Growing stocks tradeable on the timber market, carbon sinks tradeable as carbon credits on the carbon market as set out in Article 17 of the Kyoto Protocol, and Article 6 of the Paris Agreement
} 
evidence on the necessity of management standards. Using case studies on political decision making (parliamentary discourse on the definition of good practice in forest management) and reporting processes (CBD, Habitats Directive), my thesis has identified such political data requirements and evaluated where NFI was used to satisfy those political needs, or were the preference of alternative sources of information indicated gaps or limitations in the NFI design from a policy-maker's perspective.

My thesis has explained that in response to this multitude of data requirements, NFIs have gradually evolved towards multi-purpose programmes, assessing not only singular aspects of economic interest in forest policy but they have as well been extended to address the multiple aspects of climate change and biodiversity. In spite of having noticed these extensions, my study has also observed the partial inability of NFIs to satisfy all data requirements in an exhaustive manner. In such cases alternative programmes were politically preferred over NFI information. As a result, many reporting processes still rely on a fragmented set of data sources provided via different inventories with sector-specific foci. Examples of such different inventories are the NFIs, European Forest Health- and Forest Soil Inventories (under UNECE-ICP Forests), diverse national biodiversity monitoring programmes, individual monitoring efforts by ENGOs and scientific case-studies. The fact that many of the different sampling methods, inventory protocols and analysis algorithms produce incomparable estimates, leads to the question whether information requirements may be addressed more efficiently and / or more comprehensively by a harmonised inventory-, monitoring- and reporting framework. In such a programme a single inventory- and measurement design that could also be planned and administered by one organisational infrastructure of cooperating authorities, might possibly allow more cost-efficient measurements that, at the same time, generates comparable information. Such harmonisation of methods could then not only facilitate scientific analysis and estimation, but it might also contribute to the comparability of policy-performance measurements at the different sub-national and international levels.

\subsection{Data requirements and options to improve inventory designs}

\subsubsection{General overview on the policy background}

If the objective is to improve the relevance of inventory programmes, then it is crucial to understand political questions and to respond to data requirements. Providing insight on such requirements at national levels, my study found that German parliamentarians required 
information on the question whether forests were managed sustainably and whether further legal regulations were needed. For the purpose of measuring the political achievements towards "good practice in forest management" and to inform the political discourse on that topic, the parliament was found to consult evidence on variables concerning attributes of "good practice" as defined by the criteria of Winkel and Volz (2003). That information comprised evidence on deforestation of areas with different types of ownership structures, as well as the extent of tree-cover and tree-cover loss on areas managed by agroforestry systems and on short-rotation plantations. Also the status of forest health, biodiversity (dead-wood, tree species and woodland bird indicator) and the adaptation of forests towards climate change were important variables.

The parliament specifically highlighted the importance of transparent and large-area estimates (rather than case-studies) to inform discussions on legally binding agreements and to provide information under reporting obligations such as the EC-Habitats Directive, UN-CBD, UNECE-CLRTAP, UN-FCCC/KP and UNCCD. We may conclude that if scientists want to contribute such politically relevant information in future, then they should devise techniques and monitoring programmes that provide a more holistic overview on the three sectoral policies that currently set legally binding targets for some of the components of sustainable forest management: carbon sequestration (UNFCCC/KP), forest health (UNECE-CLRTAP), biodiversity (UN-CBD) and forest landscape degradation (UNCCD). To inform ongoing national discussions on the future implementation of additional legally binding management standards, German inventory specialists may use the criteria of "good practice in forest management" (defined by Winkel and Volz, 2003), whereas on the global level, discussions on management standards under UNFF may be informed by evidence on the status of the forest principles which are currently specified by the FAO C\&I reporting process under the global FRA.

There is, however, a problem with the mandate of NFIs to provide such information, both on national discussions on good practice in forest management and the FAO's C\&I. The reason is that neither national parliaments in Germany, nor the global UNFF process have yet defined an all-inclusive legally-binding definition of "sustainable forest management" that may serve to justify inventory mandates. Further, in absence of a comprehensive, all-inclusive legallybinding definition, there was yet no political pressure, will or need that could motivate national policy-makers to allocate additional funds for additional statistically-based assessments and to define the required monitoring mandates. Instead, sectoral policies gained 
momentum. Thus, the German parliament found legally-binding policies on biodiversity, climate change and forest health to be a more solid basis for the NFI mandate. In line with these observations my thesis proposes inventory specialists to focus on data requirements inline with those already developed by legally binding reporting obligations. These comprise four types of issue-specific policies that frame the concept of sustainable forest management today: (1) the UN-CBD and the EC Habitats Directive (issue area: biodiversity), (2) UNCCD (issue area forest landscape degradation), (3) UNECE-CLRTAP (issue-area forest health and resilience to climate change) and (4) UNFCCC (issue area: productivity and carbon sequestration). Due to the fact that most of the respective secretariats of the conventions (other than UNECE-CLRTAP secretariat) are also members of the Collaborative Partnership on Forests (CPF), a platform that helps co-define a legally binding definition of sustainable forest management, we may conclude that meeting such sector-specific requirements in a harmonised and all-inclusive way may also help to keep the topic of SFM on the political agenda and better inform discourses on legally binding management standards in future.

The political recognition and valuation of multi-purpose NFI information, the legal extension of the German NFI mandate, and especially the inclusion of the relatively new topic of biodiversity, eventually pose a fresh challenge for the NFI design. The advantages and limitations of the German NFI became evident by analysis of biodiversity reporting obligations under the agreements of the European Commission's Habitats Directive and the UN-CBD. Results on the utilisation of forest information for reporting commitments under EC-Habitats Directive have shown the new political dimension of NFI variables: they are now supposed to initially identify specific forest habitat types (Annex I Habitats Directive), and then to compile an index for the biological value of such habitats. That index requires fieldbased measurements of forests structural components such as "dead wood", "number of canopy classes", "percentage cover of forest development stages" and the "number of habitat trees", all of which are currently defined and provided by NFI (cf. NFI manual in: BMELV, 2014). Other important aspects in biodiversity monitoring and reporting programmes comprised variables describing "threats and pressures" that might limit the spatial extent of habitat areas now or in the future, and the description of "threats" that compromise the status of forest structural components on such areas. Such variables are less well defined and more difficult to measure, which meant that they were not provided by NFI but via expert assessment. At this point there is still untapped potential were inventory programmes may improve their techniques in order to satisfy such data requirements by verifiable measurements. 


\subsubsection{Assessing causal agents and threats to forest status}

Within NFI assessments, the challenge with meeting such biodiversity reporting requirements was, however, the difficulty to measure and assess "threats and pressures" affecting the ecological status of European habitat types now or in the future (status and forecasts), and the elicitation of variables and critical levels that best describe causative stressors. Identification of such stressors is far from trivial. The reason is that not any human intervention may imply negative consequences on the ecosystem. Kändler (2006), for example, showed that human activities that are usually associated with adverse effects, such as the extraction of trees, did sometimes correlate positively with biodiversity gains such as the occurrence of dead-wood, an indicator that is usually associated with benefits for structural diversity and species richness. Though some of the agents, that could possibly pose a threat to biodiversity, may be identified using NFI data, the inventory has been criticised for neglecting those agents that are most relevant for biodiversity (Kändler, 2006; Reif et al., 2005). Obviously, a clear and unambiguous identification needs to differentiate potential threats from those with confirmed effects. The problem in such assessments is however the thematic scope of measurements, which usually require a wide array of different variables describing the potential threats, optimally eliciting confirmed threats in an experimental design and on permanent sample plots. My analysis has shown that NFI was yet unable to meet such biodiversity requirements and provide extensive measurements of all potential threats, causal agents and effects. This is not surprising to see, given that the major objective of NFI was to produce spatial estimates at highest possible statistical accuracy by observing a largest possible number of samples. Conducting extensive and costly measurements of all potential threats (e.g. air pollution) and their possible response variables (e.g. biodiversity effects) on every individual sample plot was probably beyond the overall scope, funding and set-up of the NFI programme.

Hence, instead of using NFI information or comparable sample-based inventory programmes, reporting authorities often replaced the option of extensive measurements of threats and pressures by subjective methods. Such methods were employed by alternative biodiversity monitoring programmes under supervision of the State's environment agencies and included expert opinion in combination with visual assessment of variables such as species abundance, forest health and soil properties. I have already explained that the problem with such subjective methods was the statistical estimation of areas. This meant that estimates of statistical uncertainty, as traditionally produced by NFIs, were impossible to generate by alternative expert assessments. It is therefore not surprising to see that the biodiversity 
monitoring programmes of States did not provide estimates of statistical uncertainty with their final reports.

This observation leads to question if inventory designs strictly based on statistical principles might provide an alternative to subjective methods. It was revealing to see that the ambiguous assessments of environmental threats and pressures are already available via more standardised inventory programmes of the national forest health- and forest soil inventories (ICP Forests Programme) (e.g. air pollution, soil acidification, drainage, climate change on biotic and abiotic components of forest structure). Until now, only the UN's FRA 2015 (in: FAO, 2016) used such information as a default data source to draw conclusions on environmental threats and pressures. Maes (2013) has proposed that the same type of data (e.g. nitrogen deposition) might also be useful for the assessment conservation status at EUlevel. Due to this political acceptance and the scientific value of ICP forests information, we may infer that cooperation between NFI and harmonisation with the ICP Forests infrastructure of Level I and Level II plots (ICP Forests Programme) may provide an option to replace qualitative expert opinion by verifiable measurements. Given that both programmes, the NFI and ICP Forests, are overseen by the Thünen Institute, exchange of scientific expertise and coordination of efforts to generate comparable inventory methods should be feasible from at least an organisational point of view. In fact, a comparison of the respective inventory protocols indicates that such coordination and streamlining of methods is already happening. By now, both inventory programmes, those under the German NFI and the ICP Forests, use comparable methods such as to allow the usage of ICP-Forests' measurements for purposes similar to those of NFI (cf. manuals in: UNECE ICP Forests (2016) and in: BMELV (2014)). Examples are comparable thresholds for volume based measurements (min. diameter at breast height $=5 \mathrm{~cm}$ in ICP forests vs. $7 \mathrm{~cm}$ in NFI) and observations of tree seedlings/regeneration ( $\leq 0.5 \mathrm{~cm}$ in ICP Forests vs. $0.2-0.5 \mathrm{~cm}$ in NFI). Also the location of the basic sampling grid is comparable even though it is only co-located but not identical with ICP plots (NFI 4 x $4 \mathrm{~km}$ grid shifted by $200 \mathrm{~m}$ from 16 x $16 \mathrm{~km}$ Level I grid, both orientation Gauss-Krüger geographic system). It is to note that this shift may create some problems for site-based assessments but national-level estimates may still be possible. In fact, a perfect overlap was impossible to make. The reason is that for NFI to be representative, sample points must be invisible, whereas ICP Forests sampling plots are heavily equipped with permanently installed (and very visible) measurement devices (cf. manuals in: BMEL, TI, 2014; UNECE ICP Forests Programme Co-ordinating Centre, 2016) . 
Finally, besides the advantage of producing verifiable estimates in support of reporting obligations under Habitats Directive, joint monitoring efforts of NFI and the ICP inventory infrastructure may also contribute to utility in the framework of Forest Europe and FAO reports where data form ICP Forests is already well-established as a default data source. In the past, the ICP Forest Programme earned its credit for such international reports from its inventory design. Its major assets were certainly its sample grid, the unambiguous inventory manual and standardised assessment methods which are harmonised across assessments in all European states and therefore allow comparability of European assessments published in Forest Europe and FAO reports.

\subsubsection{Assessing rare species and ecosystems}

Besides the assessment of threats and pressures, additional challenges relate to the NFIs inability to sufficiently cover "rare" events, i.e. events that are not sufficiently included by the NFI sampling design. These include large-diameter deadwood, indicator species of the ground vegetation and fauna such as birds, butterflies and mammals. Many of such variables are not only important for conservation status indexes under Habitats Directive but, potentially, they could also be input for the German indexes assigning a status of "threat", i.e. vulnerability to extinction, to species and ecosystems (Red Lists in: Ssymank et al., 1993; Rieken et al., 1994; Fink et al., 2017). Such indexes have become a powerful source of information and especially the so-called "Red Lists" benefit from political links to influential ENGOs. The methodology of such species assessments is based on the methods of one of the most influential ENGOs, the IUCN, which also played a pivotal role in the drafting of the CBD treaty and thus helped to co-define the first legally binding convention on biodiversity conservation (Raustiala, 1997).

Due to its strong affiliation with IUCN and the ENGOs political power, it was not surprising to see that the Red List indexes remained to be a prominent source of information for global biodiversity reports under the parent policy of UN-CBD. With respect to its political significance, similar observations have also been made by Rodrigues et al. (2006) who found that the index had become increasingly influential, especially for conservation planning, management and decision-making. However, there are limitations within the underlying assessments and the methodology of index compilation. The trustworthiness of the IUCN Red List had been questioned, also as a result of its political affiliation, its ties to the political 
agenda of CBD and weaknesses within its methodology that may be skewed to meet political targets (Mrosovsky, 1997; Possingham et al., 2002; Webb, 2008).

Indeed, the Red Lists are not part of a standardised probability-based inventory protocol, but since their establishment and the publication of the first IUCN "Red Data Books" which allocated species to categories of threats in the 1960s (Scott et al., 1987) they rely, at least to some extent, on expert opinion. Input data is further fragmented and comes from a variety of sources such as scientists, organisations and volunteers (Rodrigues et al., 2006; Webb, 2008). As a solution, joining efforts or expertise in statistical sampling with harmonised probabilistic inventory designs such as NFIs, the Red-Lists could possibly avert criticism (Mrosovsky, 1997; Possingham et al., 2002; Webb, 2008) and perceptions of being biased, subjectively or politically.

There are many other reasons to suggest that standardised and probabilistic inventory designs may be a viable option to replace qualitative assessments and expert judgements. In fact, previous experience, especially from Sweden, has shown that sample based inventories have successfully tackled the concern of inclusion probability or rare features or of occasional events (e.g. mobile species) which currently seems to prevent German biodiversity reporting authorities from using standardised plot designs. Also, Fewster et al. (2009) and Buckland et al. (2009) suggest that line-distance or adaptive cluster sampling may be viable options to increase inclusion probability of rare occurrences of fauna. Also in other countries such as the in the United Kingdom (UK Breeding Bird Survey (BBS)) (Stuart et al., 2005) and New Zealand (Greene et al., 2010) applications of line-distance sampling have shown that such methods also worked out well in practice and may be integrated in nation-wide monitoring programmes. Kändler (2006) even recommended such methodologies for the German NFI to increase inclusion probability of rare tree species such as the European chestnut (Castanea sativa). The political reaction to these ideas on using new methods for the assessment of rare occurrences of flora and fauna is revealing. Even though since 2012, the new NFI (BWI 3) included new variables for the assessment of biodiversity, it has dropped the assessment of rare species altogether. This indicates that the extension of the plot- or sampling design to line-distance sampling was either impossible due to technical reasons (e.g. comparability against previous assessments) or due to financial constraints (additional time and costs associated with laying out new sub-plots or training and teaching taxonomy to field teams).

Indeed, costs and the availability of well-trained taxonomists seemed to be a major obstacle when assessing rare events. Yet, this does not appear to be a problem that cannot be solved. 
At the BBS, the costs associated with time-intensive assessments of species abundance were kept at a minimum by the help of citizen science, a concept that is increasingly tested and gaining acceptance for labour-intensive or large-range field work (Tulloch et al., 2013; Rees and Pond, 1995, p. 107). The BBS further addressed the issue of subjectivity and observer bias by throughout standardised field protocols in combination with professional guidance and advice. A well-organised administrative body with regional inventory organises and supervision further ensured professionalism within assessments and sound coordination of field assessments. Similar experience has been made in Germany with the butterfly inventory supervised by the Helmholtz Centre for Environmental Research (inventory guidelines: Kühn et al., 2014 and online at: www.ufz.de/tagfalter-monitoring). Eventually, besides avoiding costs that would have resulted from full-employment, one of the major advantages was seen within the enthusiasm of volunteers and their honest dedication to contribute to "real science" (Tulloch et al., 2013). Also Rees and Pond (1995) approved unbiased motives and state that "volunteers have no political, economic or personal motives for influencing the data collected which is therefore completely impartial" (p. 107). A representative of the EC European Topic Centre on Biological Diversity even mentioned political advantages of citizen science during a 2018 workshop (organised by the project: "Distributed, Integrated and Harmonised Forest Information for Bioeconomy Outlooks", www.diabolo-project.eu). The argument was that the involvement of the public and their enthusiastic support may create political pressure to keep problems of nature conservation on the political agenda and to tackle the political issues (Evans, 2018, personal communication).

The question is, if such a monitoring system could translate into the German context. German ENGOs and the Helmholtz Centre for Environmental Research already have a wellestablished network of volunteers and national and regional offices that coordinate species assessments. The reporting processes described by Chapter 5 further described that such activities are well-linked with professional habitat monitoring programmes of conservation agencies at Federal- and State level. Hence, missing links between reporting authorities and enthusiastic volunteers are certainly not the primary issue.

A problem is however the accurate and precise identification of flora and fauna. Volunteers and even some field biologists are generally more interested, and better trained, in the identification of those species that are generally perceived as beautiful and worthwhile to protect. Examples are flowering or eatable plants, colourful birds and butterflies, large charismatic mammals such as the field hamster, the wild cat, the wolf or the lynx. Less 
famous and also less known are other, but often similarly threatened, species such as those of bats, moths, amphibians, mosses and lichen. This issue is well known and in fact, the limited availability of taxonomic experts is a general concern in most biodiversity monitoring programmes. The problem has thus led to new initiatives such as the projects International Barcode of Life (iBOL, www.dnabarcoding.org) and its German counterpart, the German Barcode of Life (GBOL, https://www.bolgermany.de). The German project brings together various universities, public and private research institutes, natural history museums, zoos and herbaria and is currently funded by the German Ministry for Education and Research (BMBF). The organisers aim to compile a comprehensive reference system for the DNA of species. That database should eventually allow species identification via the so-called method of "DNA-barcoding", a technique that was first developed for the automated identification of mammals and published by Paul Herbert and his team in 2003 (Herbert et al., 2003). These ideas were quickly picked up by the scientific community and had been extended to other species of flora and fauna. Now, the technique allows the accurate and precise identification of species via a sequence of DNA extracted from tissues, pollen (Bell et al., 2016) or even excretion or secretion (Dejean et al., 2011). The possibility to sample such traces means that rare or mobile species, that usually go unnoticed in standardised inventory programmes, could be inventoried without trapping or any direct contact, just by using their genetic footprint.

However, the efforts linked to DNA purification, analysis and the not yet complete reference database raise further questions on financial feasibility. In an interview (NeFo, 2017), Horst Wägele, the director of the German organizing research team for the GBOL project at the Zoological Research Museum Alexander Koenig (ZFMK), responded to such questions regarding the practical feasibility of a genetic monitoring programme. He estimated the overall costs associate with the setup of the reference database and the extension of laboratory- and computing capacities at 40 up to 50 million Euros, expenditures that he saw as comparable to those of climate research. He further believed that these cost could be covered via existing monitoring budgets provided by Federation and States. In addition, "many [other] institutions had shown interest in contributing financial resources for the clarification of the [famous] insect dieback, and especially in a monitoring programme" (translated by the author). Finally, he saw untapped potential in other sectors and proposed the idea to place financial obligations on those who cause environmental damage, especially agriculture and industry. In fact, by the "cross compliance" mechanism and its "polluter pays principle", the European Common Agricultural Policy (CAP) already includes a rule that obliges farmers to pay for certain environmental damages. It is however yet more than unclear to what extent 
farmers actually contributed to the insect dieback and if the CAP mechanisms could really be translated into a funding scheme for monitoring programmes. Also the political will of those ministries representing sectors of agriculture and industries and their motivation to establish funding schemes for genetic monitoring programmes might be questionable.

Eventually, as it is generally common to most new project ideas, the exact costs and how they will be covered are still unclear, yet the primary advantage of DNA barcoding, when compared to visual field based observations, is certainly a lower dependency on specialist taxonomic skills, while at the same time, producing high accuracies (Herbert et al., 2003; Janzen et al., 2005). These benefits might eventually provide opportunities for monitoring programmes to involve volunteers more efficiently (e.g. to support the collection of DNA material), and to identify a wide array of different species at a high level of accuracy.

If these technological potentials are possible to integrate in a concept of citizen science and if such a programme may be coordinated and harmonised with activities of forest-inventory authorities remains a question to be solved. While the idea of DNA barcoding has not yet been discussed in the political community, the Federal Ministry for the Environment, Nature Conservation and Nuclear Safety (BMU) has already voiced general ambitions to enforce sample-based monitoring programmes by citizen science and to train the public by making taxonomy an established part of school and university curricula (Integriertes Umweltprogramm 2030 in: BMUB, 2016). This shows that citizen science is already a part of the political agenda and it might have prospects to be implemented in the near future. If the objective is to remain politically relevant and to secure scientific credibility of future biodiversity monitoring programmes, then NFIs shall join the discourse and provide technical advice how to harmonise concepts of citizen science with standards of statistically based biodiversity inventories.

\subsubsection{Meeting data quality standards}

\subsubsection{Mapping}

My thesis has also addressed political requirements regarding data quality. Findings provided additional insights on how a more policy relevant inventory design could look like and how the data could be presented to better communicate scientific evidence to policy-makers. Results on the measurement and assessment methods of data sources that were preferably 
chosen by the German parliament, or by the secretariats of EC and UN showed that there were basically two types of successful measurement methods:

1) Sample-based information, and

2) Remote sensing-based mapping programmes;

and three types of data formats:

1) Field measurements (numeric);

2) Results of analysis algorithms (numeric); and

3) Interpretations (qualitative).

Remote sensing was typically more relevant for quantification of spatial metrics such as landuse, land-use change and fragmentation. In such cases providers at the UN and the EC secretariats generally preferred data from data that was assumed (but, according to Chapter 4, not always confirmed) to be "full-coverage", i.e. from landscape plans and from aerial image interpretation, both of which did not always use completely standardised assessment rules. Yet, for numeric evidence, such as species abundance, the secretariats accepted samples from ground measurements. As for the preference of remotely sensed data in European and Global reports to the CBD secretariat, the major advantage was probably seen within the properties of forest cover maps which provided georeferenced and spatially explicit information at a very high spatial resolution, something that sample-based forest inventory (at least 4 x $4 \mathrm{~km}$ in Germany, at least 5 x $5 \mathrm{~km}$ in Sweden) is not designed for.

Maps generated from remote sensing programmes further allowed the spatially explicit delineation of forest areas. These provided information on both, the spatial extend of forest areas, as well as the explicit delineation of forest boarders. Such information is important because the CBD requires the establishment of "a system of protected areas or areas where special measures need to be taken to conserve biological diversity" (Article 8a). The European Union Habitats Directive implements this requirement through the legally binding obligation to establish the Natura 2000 network of protected habitats, which includes, among others, specific forest areas such as those listed in Habitats Directive's Annex I. It is obvious that planning and protection of such areas requires spatially explicit information on the geographic location. In Germany and Sweden that kind of information is primarily generated through remote sensing programs, partly in combination with semi-automated image classification and 
standardized methods of ground-truthing (NFIs in Sweden) or by manual delineation of forest habitat polygons, site-visits and expert assessment (Biotope and habitat mapping programs of Federal Sates in Germany). Standardized sampling programs such as NFIs, in contrast, are not designed to produce such maps, but instead they are more targeted towards estimating averages and the overall extend of areas for an entire nation or for a national sub-region (e.g. Federal States in Germany). If not combined with remote sensing programs, such information did not satisfy information demands and was therefore not requested or chosen for reporting spatial metrics such as land-use, land-use change and fragmentation.

Another advantage of remote-sensing programs was certainly their ability to cover multiple political jurisdictions on the national and international level which allows a comparison of countries and a relative comparison of performance. This observation is not new, the need for internationally comparable data was also recognized by scientists involved in the programme COST Action E43. That programme has led to extensive harmonisation efforts of NFIs on an international level. Yet, such NFI data did not become politically relevant for reporting purposes of EC and $\mathrm{CBD}$, but instead, reporting authorities preferred land-use maps from the CLC project. This observation indicates that it is not enough for NFIs to provide comparable data across borders of political jurisdictions. Rather, data shall provide answers on the topic of biodiversity on multiple land use types, beyond the scope of forest areas. Finally, to conclude, if the objective is to be politically relevant, then NFIs shall integrate remote sensing programmes to provide spatially explicit information on multiple land-use types and across political jurisdictions. A first step to a landscape-scale inventory is already being done by the NFI of Germany which includes a variable on "land use, land-use change and forestry" (LULUCF). Yet such information is still restricted to land-use changes at forest edges and does not yet include a larger landscape scale approach, which would include trees outside forests, orchards, agroforestry and other agricultural areas. Chapter 4 has explained that such a landscape scale approach is already implemented in Sweden, which joined the different monitoring programmes that had already been established in- and outside forests. The effort could be seen as a cost effective approach, because the programme focussed on joining existing inventories and funds. In the end, costs did not seem to be a major issue. They were covered by the national government and the EU LIFE+ research grant, thus allowing to project to go ahead.

We have seen that the use of remote sensing data was common in reporting processes, both nationally and internationally. However, in Germany, the analysis was not always 
standardised: Here, the biotope mapping programmes of Federal States generally employed visual interpretation without a completely standardised set of measurable indicator variables or automated algorithms for pixel-based classification. A possible reason for marginal application of such technologies might have been the historical development of the States' monitoring programmes, many of which started long time ago (e.g. Lower Saxony in the 1970s; Kröber, 2001) at a time when commercial user-friendly software such as the eCognition ${ }^{\circledR}$ software (launched after 2000, cf. www.ecognition.com/category/relatedtags/product-history) was not available. A reason for not using alternative means of computeror algorithm assisted image classification might be limited experience and the costs associated with the employment of specialised statisticians and programmers. Reason is that the correct selection of sensors and the processing of such data require knowledge of properties such as spectral and spatial resolution. Replies to a 2012 survey which investigated data needs of conservation agencies suggested that such specialised knowledge was often limited (Hagenlocher, 2012). Thus, when asked what kind of spatial resolution they required, the majority of the respondents replied arbitrarily (Hagenlocher, 2012). Also I have observed that within their own inventory guidelines some defined their needs for spatial resolution subjectively as "site-specific, as precisely as possible" (flächenscharf) or by the scale of maps (e.g. 1: 10000) rather than by the resolution of measurements (Sachteleben and Behrens, 2010a). From similar statements, the surveyors of the previously mentioned study (Hagenlocher, 2012) concluded that most of the interviewees (included data providers to the Habitats Directive) were not able to respond properly because they were neither remotesensing nor GIS experts. Another report of the same study concluded that the utility of remote-sensing data was often overlooked by administrative biodiversity conservation because such technologies are not traditionally included in biological surveys (Lang, 2012b).

\subsubsection{Sampling}

While the advantages of remote sensing and mapping programmes are obvious when it comes to the national implementation of the CBD and Habitats Directive through planning and managing protected areas, a different explanation must be made for the partial acceptance of sampling. Chapter 4 showed that reporting authorities accepted sampling for reporting the variable "conservation status" (categorical: from favourable to unfavourable bad) of forest "structures and functions". This observation is better explained by reporting obligations 
formulated by CBD and Habitats Directive. In Article 7 of the CBD states that: "Each party shall [...] Monitor, through sampling and other techniques, the components of biological diversity (Article 7b, CBD, 1992), [and] processes and categories of activities which have or are likely to have significant adverse impacts on the conservation and sustainable use of biological diversity" (Article 7c, CBD, 1992). The Habitats Directive further specified the topic of such sampling programmes, when it obliged its member states to monitor conservation status of habitat types (listed in its Annex I) per biogeographical region on a national level (Article 11 and 17, CBD, 1992). To conclude, if the objective was to assess a nation's overall compliance with that obligation, then sampling and estimation of national averages of conservation status was sufficient, whereas the geographic location was not crucial (as it would have been provided by full cover mapping programmes).

From an inventory perspective, the acceptance of samples for the assessment of the conservation status raised the question as to what kind of methods of measurement, plot- and sampling design, and which levels of statistical precision and accuracy were regarded sufficient by reporting authorities and thus led them to utilise such data for compiling national reports. It would have been beyond the scope of this summary to repeat all the respective methods here in this chapter, for details I would therefore like to refer the reader to Chapter 4. Suffice to say that in both case-study countries, Germany and Sweden, pre-stratification was regarded an important method to delineate sites with a potential occurrence of EU habitat types (Annex I Habitats Directive) and to increase the precision of estimates. In Sweden, the target of such sampling efforts was to achieve sample sizes of at least 30. Area estimates generated as a result of such sampling then achieved relative standard errors of $59.4 \%$ to $0.04 \%$, depending on habitat type. Data at such levels of uncertainty were then used for the national report. The availability of such measures of uncertainty was important because they provided an indication of national quality standards.

The situation was less obvious in the case-study of Germany, especially for assessing and reporting habitat areas. Here, the statistical accuracies required by providing authorities were less evident from the inventory design: Even though there was a random sample of a defined size $(n=63)$, for the assessment of structures and functions on habitat areas, there was a problem with randomisation because the random sample was taken from areas stratified and inventoried within an earlier stage, i.e. during the State programmes. Chapter 4 has explained that these programmes had some limitations with respect to probability sampling, because in all Federal States, other than in North-Rhine Westphalia's "Ecological Area Sampling" 
(Ökologische Flächenstichprobe in: Dröschmeister, 2001), the general method was qualitative expert assessment. The manuals and rules for measuring indicator variables on the plot and for classifying remotely sensed images were then often ambiguous enough to allow field teams to interpret and make own definitions (e.g. variables such as "moist" or visual image classification without rules guiding the interpretation or spectral reflectances).

This problem of ambiguous rules is most likely to lead to very different results, depending on interpretation, or possibly, if there is conflict of interest, on political motivation (cf. Chapter 6.3). An example is the identification of habitat areas, where indicators often had no clear definition of scale (e.g. number of indicator species) or no precise threshold values to indicate presence of a habitat. In such cases, there could have been an option of skewing the ambiguous inventory rules towards a politically preferred result. Sometimes, there was also a possible motivation to do so, especially when the assessors had a conflict of interest. This was occasionally the case when land-owners were in charge of mapping and when they actually found evidence of habitat types. This would lead to protection obligations and monetary burdens under the rules of compensation measures (Article 6 (2-4) Habitats Directive and $\S \S$ 14, 15, 19, 34 BNatSchG). Hiding evidence of habitat types would then be a potential political motivation for skewing inventory rules (cf. Chapter 4). Responses from an EC representative interviewed in the course of this study confirmed such observations. Without citing any particular Member State, he remarked that he is "aware of a few cases where Member States reported lower than actual area figures for specific habitat types, presumably in order to produce a politically favourable outcome, thereby faking a lower-than actual need for Natura 2000 site designation." On the other hand, he mentioned that he is "also aware of cases where higher-than-actual area figures have been reported for certain habitat types in certain member States (including one example of all forest habitat areas in one member country being systematically overstated by the national forest administration), which upon verification turned out to be due to methodological errors. Although such erroneous habitat area values only concern a small minority amongst all area values reported by the Member States, and although the majority of the Member State seem to make substantial effort to produce reliable area figures for each and every habitat type, the above incorrect area data obviously hamper the production of reliable EU level habitat area figures" (Vassen, 2018, personal communication).

Although interviewees highlighted that such disadvantages were more common in other Member States, whereas Germany was praised for its achievements in its monitoring and 
reporting procedures, we may conclude that generally, biased habitat reports were made possible by vague and ambiguous assessment rules that allow political interests to skew assessment result towards a favoured outcome. This study observed that some problems of ambiguity still persisted, even after extensive harmonisation and standardisation efforts.

This disadvantage leads to question why, for area assessments, inventory- and reporting authorities still preferred general over precise definitions. One reason is evident from BfN publications on the value of the German NFI II (Reif et al., 2005) and NFI III (Reise et al., 2017) for biodiversity assessments. Generally both papers commented that NFI would have needed much more variables on the specific topics of species composition, their interactions, their threats and the biotic and abiotic processes in forest ecosystems in general. Such assessments, however, require extensive and costly measurements of all variables that could be suspected to have a potential effect on the many components of biodiversity. It is obvious that for NFI, an inventory that was originally designed and funded to estimate the overall abundance of a nation's resources, it would have been too time-intensive and costly to assess the many variables typical to observational studies which usually focus on very few plots within a confined case study area. Conversely, for observational case studies, an extensive inventory grid, with a high number of sample plots representative for the entire landscape of a country, is usually beyond purpose and funding.

Another possible explanation for the small uptake of large-area probabilistic inventory designs in biodiversity monitoring programmes could be limited experience within the field of large-area statistical estimation. A pilot project on the optimisation of remote sensing data in Germany's Federal States came to a similar conclusion (Rühl, 2016). They suspected that within the field of biology and biodiversity conservation, statistical estimation of areas is not traditionally used. Indeed, governmental agencies, who are the general data providers in Germany, have the primary responsibility to administer, plan, implement and monitor conservation efforts and their effects on the operational level. This mainly includes the supervision and general organisation of research projects that often have been outsourced to third parties such as consultancies, research institutes and universities.

Academic institutions such as universities and "scientific" research, in a narrower sense, therefore influence policy only indirectly via governmental administrations. For the purpose of funding such research, the Environment Ministry specifies required research projects within its annual "departmental research plan" (BMUB, 2018). For the administration and 
scientific supervision of such projects, the programme also nominates respective departmental agencies. The focus of such agencies is thus administration and funding of original research for the purpose of translating results into policy advice. The agencies thus represent the bridge between the science policy-gap, where they reach out to the science community and handover the more technical part of research to professional institutions. The more traditional part of research such as the development of new algorithms and technologies, including their verification via traditional scientific discourse and verification as guaranteed by publication in independent peer-reviewed journals is thus the responsibility of third parties with more experience in traditional "science". Similarly, a relatively small number of scientific staff and resources, when compared to more science based institutions such as universities, indicates that it is beyond the organisation conservation agencies to develop scientific expertise comparable to university standards. Lower nature conservation agencies at the state and local level usually have the smallest research budget, and an even stronger focus on administrative tasks, which means than there are fewer options to invest in traditional scientific research projects and expertise. These arguments could possibly explain why data quality standards defined at the state level were often ambiguous or unclear from the literature. Perhaps, a monitoring programme that rigorously employs the latest scientific knowledge was beyond the set-up of departmental research agencies. Such projects usually require additional funds, that allow for research intensive projects, including the employment of scientific staff (e.g. mathematicians, statisticians, biologists and engineers), maintenance of technical equipment (IT-infrastructure, laboratories, measurement devices), and investment into background data (e.g. remote sensing imagery, reference databases).

\subsubsection{Streamlining inventories to meet quality requirements}

These observations yield the question if there was an option to limit the described shortcomings and if it was actually possible to share the existing funds and the subjectspecific expertise of reporting authorities currently engaged in biodiversity assessments and NFIs, and to replace arbitrary methods by an alternative and randomized design that allows spatial estimation at known levels of uncertainty. We have seen that the Swedish habitat monitoring programme is based on solid experience in remote sensing and area-based estimation. It has been linked to the NFI since 2008 and therefore benefits from long-term expertise in area-based estimation. Conservation agencies of the German Federation and its States, in contrast benefit from specialist knowledge in the field of biodiversity and the most important variables describing ecosystem functioning. 
Swedish experience has also shown that such an all-inclusive approach and cooperation between an NFI and biodiversity assessment is actually possible. A combined inventory may even address challenges of sampling rare habitat types, something that has been raised as an argument not to use NFI in German habitat-area assessments (cf. Sachteleben and Behrens, 2010a). Indeed, the Swedish inventory has shown that a sample-based inventory design may sufficiently account for rare events, if it stratifies sites to reduce sampling costs. Taking the Swedish inventory as a role model, the German policy makers might also consider options of increasing funding and extending the inventory mandates such as to enforce inventory designs, foster cooperation between existing schemes and to further link or streamline habitat monitoring programmes with the statistically based inventory infrastructures of NFI (for assessment of habitat areas and forest structures), as well as with forest health and soil inventories (for assessment of threats and pressures). Previous harmonisation efforts between NFI and BfN (Sachteleben and Behrens, 2010a) indicate that such a joint effort avoids duplications and may even lead to cost reductions, provided that each of the programmes contributes its own funds.

Current developments show that the issue of funding and streamlining German inventory designs to produce rule-based, rather than ambiguous inventory protocols are already being discussed: First ambitions to interpret remote sensing images by automated or semiautomated image classification (rather than visual assessment) started with a 2014 workshop on the utility of remote sensing data for habitat monitoring (Buck et al., 2014) and the launch of a pilot project (Rühl, 2016) on the implementation of data from the EU remote sensing programme "Copernicus" (optical sensor Sentinel 2) into the Federal States' ground-based monitoring programmes. Participants with representatives from universities, Federal - and the Federal States' conservation authorities also acknowledged the importance of streamlining State-specific remote sensing programmes and to identify common indicators that are useful for image interpretation (Buck et al., 2014). Such discussions do not only exist in Germany, also EC projects show that ideas on the integration of NFIs and remote sensing for harmonised landscape-scale inventories are already being tested on the European scale: A follow-up programme of the COST Action E43, the project "Distributed, Integrated and Harmonised Forest Information for Bioeconomy Outlooks" (DIABOLO) has started in 2015 under European Union's Horizon 2020 fund. It wants to provide better and internationally comparable information for various reporting obligations, including the Habitats Directive. For this purpose, it currently identifies the political information demand from various political reporting processes (FAO, UNFCCC, CBD, Habitats Directive, EU Member States) and 
develops techniques for the integration of NFIs and remote sensing programmes. These initiatives show that the reporting obligations discussed in this thesis and their implications for inventory protocols are already being discussed, especially by data providers such as the $\mathrm{EC}$ and the FAO who are eager to make their information more policy-relevant, especially for political decisions of the European Parliament and the UNFF. For this purpose, they want to join forces and streamline inventory programmes such as to produce better information and push policy processes to acknowledge the value of information.

Yet, if internationally harmonised monitoring and reporting programmes are politically wanted and if scientific compromise on value-laden issues such as biodiversity conservation is actually possible remains a difficult question. The different and sometimes incompatible objectives and data needs of member states and stakeholders, all of which also challenged harmonization efforts in the past, could mean that there is still a long way to a rigorously standardised inventory. The possible prospects of a political and scientific compromise were named by one responded of the EC Topic Centre of Biological Diversity: He remarked that a completely harmonised reporting would probably "never be possible" because each member state wants to keep their own inventory methods (Evans, 2018, personal communication). This is actually understandable given that any change in methods requires a new political and scientific compromise, dissects timelines and involves additional costs.

Such costs are a very fundamental issue when it comes to the practical implementation of scientific ideas, especially in large scale and long-term programmes such as NFIs. Yet, there are some options: One example is the European "Life" fund established by EC Regulation No 1293/2013. The fund is tailored towards the implementation of EU environmental legislation which includes, among others, the development of new monitoring programmes (EC Regulation No 1293/2013) ${ }^{21}$. The fund has also been used to support harmonisation efforts in Sweden when the MOTH programme was set up to measure components of biodiversity in

\footnotetext{
21 "Forests play a significant role for environment and climate as regards, for instance, biodiversity, water, soil, and climate change mitigation and adaptation. Forests and soils help to regulate the climate by taking up carbon dioxide (CO2) from the atmosphere and storing immense amounts of carbon. To optimise that role, the provision of relevant, compatible data and information is necessary. This Regulation should therefore also represent a framework for supporting synergies between environmental and climate actions associated with forests and soils, including their monitoring. Other areas for increased synergies are water scarcity and droughts, as well as management of flood risks" (preface, Paragraph 16, EC Regulation No 1293/2013)

"The financial allocation for the LIFE Programme may also cover technical and administrative assistance expenses, including any obligatory monitoring, communication and evaluation required pursuant to Regulation (EC) No 614/2007 following its expiry, to ensure the transition between the measures adopted pursuant to Regulation (EC) No 614/2007 and the LIFE Programme." (Article 32, Paragraph 2, EC Regulation No 1293/2013)
} 
conjunction with the NFI protocol. However, the problem with LIFE is its dedication towards specific projects. This means that funds are available only for a limited period of time and recurring costs, such as running monitoring schemes, are not covered. Funds under the European Agricultural Fund for Rural Development (EAFRD) of the Common European Agricultural Policy (CAP) may provide other options. Yet, the problem is similar as for EU LIFE programmes: rural development funds are provided only under a specific contract, where the contracting parties may decide to end the contract at any time. This means that for both, EAFRD funds and for LIFE, long-term financing cannot be guaranteed. The expert meeting at the DIABOLO project discussed similar funding options and concluded that money remains to be a general problem. As a solution, one responded proposed that monitoring experts and specifically departmental research agencies should speak more about the funding issue, also in the European Parliament and "maybe one day they [the policymakers] would do something about it" (Evans, 2018, personal communication). It might actually be that scientists, especially those engaged with conservation, are not yet wellconnected with policy makers and a stronger lobby might provide an option to convince decision makers of investing into better quality information.

Yet, it is not only the European Union that provides options for funding of integrated monitoring programmes. Specifically NFIs are generally under responsibility of national member states. Hence the quality of information also depends upon the amount of money that national governments are willing to spend. Experience from the historical development (Chapter 1) and the amendment of the German NFI (Chapter 3) indicated, that national politicians were prepared to extend the mandate and the relevant funds only when they were under political pressure from a higher level, for instance when legally binding reporting obligation from the European Commission or the United Nations dictated quality standards. Such standards existed only for climate change reporting under UNFCCC which makes IPCC's standards of good practice legally binding to its member states. Such statistical standards do not yet exist for biodiversity and also FAO good practice criteria are not yet linked to any legally binding obligation.

Indeed climate change remains to be high on the political agenda, probably because carbon sinks have become a commodity under the global carbon market, a policy instrument of the Kyoto Protocol, Articles 6 and 17. In conjunction with such markets, the NFIs have created standardised systems for the precise estimation of tradeable forest resources, especially on growing stock, increment and feelings. The measurability of non-tradeable benefits of 
sustainable forest management, especially of ecosystem services and of biodiversity (cf. criteria in Winkel and Volz, 2003) might become more policy relevant if such aspects were commodified. Similarly as for the carbon market, a market for ecosystem services would create a need for sellers (e.g. forest managers) and customers (e.g. industries with a high environmental footprint) to verify the value of the product and to precisely measure aspects of biodiversity.

The modern-day scientific community has discussed the market value of biodiversity since Ehrlich and Ehrlich (1981) first coined the term "ecosystem services". The discussion received wider attention in the 90s when Costanza et al. (1997) have first produced a global map of the economic value provided by ecosystems. The discussion has eventually reached policy-makers with the Millennium Ecosystem Assessment (MA, 2005) and The Economics of Ecosystems and Biodiversity (TEEB, 2010) study.

Yet, such global initiatives were often fragmented and based on different sets of indicators and reporting formats. At the European level, more recent projects now try to pinpoint the economic value of forests. The initiative "Mapping and Assessment of Ecosystems and their Services" (MAES) (https://biodiversity.europa.eu/maes) was initiated after 2011, when the European Council acknowledged the value of harmonised information on ecosystem services, also in forests (European Council, 2011). The initiative has thus established a common governance structure, the so-called "Common Implementation Framework" (CIS) as a platform of reporting authorities to harmonise land-use classifications and the assessment of services provided by such land-uses across Europe. NFI information is an important input, especially for the assessments of values generated from forest biomass through carbon storage and commercial wood sales (European Commission, 2014). Yet the initiative focuses more on harmonising reporting processes, less so on field measurements and protocols.

An example for an initiative that focuses more on the harmonisation of specific measurements of habitat threes and microhabitats in forests (Schuck et al., 2015) is the initiative "INTEGRATE plus" (http://www.integrateplus.org) which was launched in 2013 by the German BMEL. The design of the initiative indicates that it may also be useful to streamline NFI protocols and to use such information for the evaluation of the economic value of microhabitats in forests: In that project, the Central European Regional Office of the European Forest Institute (EFICIENT) has installed demonstrational forest management plots, so-called "marteloscopes" (Schuck et al., 2015). The purpose of variables measured on these plots is to assess and project economic losses that result from forest management decisions 
(Pommerening et al., 2015) such as the retention of trees with specific features of microhabitats (Kraus et al., 2016; Larrieu et al., 2018). Potentially, the project could thus provide a method for foresters to estimate expenditures made for biodiversity benefits. If foresters got more options to be compensated for such losses, for instance via the CAP or some sort of ecosystem services market, then there would be a political motivation for checks and balances. Similarly as for climate reports, such a market might then lead to improved monitoring mandates, additional research funds and more precise measurements of biodiversity in national monitoring and reporting programmes.

Yet such policy instruments require political consent on the need to protect biodiversity assets. Until now, ministries (Winkel et al., 2011), political parties (Chapter 3) and UN organisations (Hofmann 2003, Dimitrov 2005, Humphreys 2006, Pülzl 2010) have repeatedly failed to come to such a compromise, that defines legally binding standards for sustainable forest management and that moves the protection of biodiversity into focus. According to findings of this thesis, a fundamental contribution to this failure comes from national parliaments, where policy makers work at the grass-roots of political decision-making. Here conservative parties and a strong forestry lobby have repeatedly blocked attempts to regulate management activities (cf. Chapter 3). Also for the future, the newly defined German coalition contract of social democrats and the conservative parties has made no ambitions to come to a legally binding definition (CDU, CSU und SPD, 2018).

\subsubsection{Data presentation and communication}

This study did not only want to explain the links between political agendas and data needs, it also wanted to analyse how the data should be presented and communicated. We may assume that such presentation and communication is important for inventory specialists to better attract the policymakers' attention and to translate scientific evidence into storylines that explain how scientific solutions work in practice and how they help to solve political questions. My observations of scientific information that became relevant in political decision-making processes, illustrated that besides the presentation of figures and facts, the interpretation of scientific evidence into qualitative policy advice was an important tool for the reporting processes to effectively communicate scientific evidence to the political community.

Evidence had been obtained from the parliamentary discourse. It showed that information was quoted most frequently and best fed into political action when it was presented in form of 
qualitative policy advice and supported by numeric results. This meant that opposed to scientists and inventory specialists who usually relied on raw measurements and spatial estimates as a source of information, parliamentarians were less interested in such information. Instead, scientific evidence was communicated most effectively when it compiled different variables to inform more complex political issues or when the scientific message interpreted evidence qualitatively in form of direct policy advice. This is not surprising to see, if we anticipate that generally, policy-makers do not have the time and knowledge to review and analyse all available background data (Gregerich, 2003). Often, they are simply not aware of scientific evidence and knowledge remains concealed until an advisor, a report or even the media presents information in a format and language that is understandable to the political reader (Gregerich, 2003). One EC interviewee even remarked that in a policy report, "the message gets lost if you talk too much about data quality" (Evans, 2018, personal communication). Too much detail is then simply distracting and "dilutes" the message because policy-makers do not understand the technical details and the meaning of data quality. In past biodiversity reports, the decision of how much detail to include was therefore always a very difficult balancing act (Evans, 2018, personal communication): On the one hand, it is important to provide information on data quality, but on the other, it is also important to simplify scientific information in a language and format that is understandable to politicians who usually do not have specialised set of skills to techniques of sampling, remote sensing, biomass functions and statistical analysis. Also a publication by ten Brink (2006) concludes that policy makers and politicians were mostly interested in a qualitative assessment of policy performance that compiles quantitative information, compares them against a political baseline scenario or target and eventually makes a qualitative judgement.

Similarly also my observations indicated that in order to remain politically relevant, scientists need to interpret and translate information by some sort of qualitative judgement. For this purpose they must become engaged with the political arena, understand political concerns, interpret information into storylines and provide answers to decision making problems. The DPSIR (Driver-Pressure-State-Impact-Response) framework is designed to construct such storylines and is already a well-established tool for famous environmental C\&I processes of EEA (Smeets and Weterings, 1999; EEA, 2015), especially for the selection, interpretation and communication of scientific evidence. Though FAO does not yet fully apply the framework for data analysis and presentation, the European Forest Institute (EFI, 2013) and UNEP (Newton and Kapos, 2002) have recommended it for indicator selection and presentation. Wolfslehner and Vacik, (2011) have even applied it to the FAO C\&I process 
where it proved its value in communicating complex scientific evidence more effectively by the identification of so-called "key-indicators". To better explain the communicative advantages of that DPSIR framework, the next paragraphs illustrate its purpose and construction by some examples.

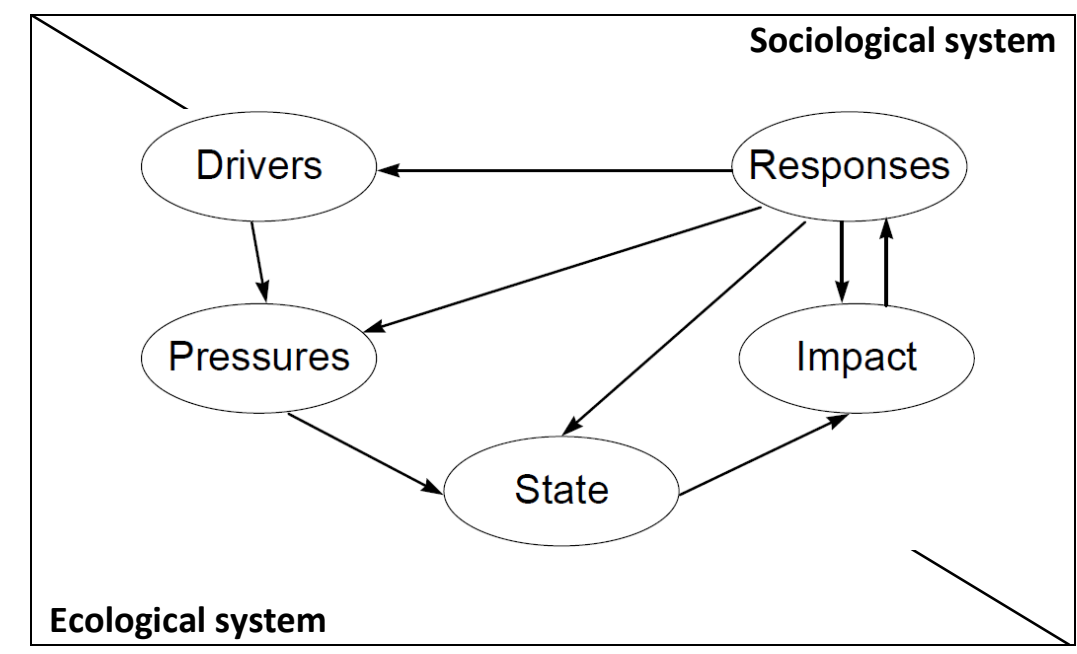

Figure 12. The DPSIR framework for reporting on socio-ecological issues (original from Smeets and Weterings, 1999) adapted and slightly changed by the author. The precise distinction between social and ecological system depends on the context of a decisionmaking problem and is to be defined by policy makers.

To introduce the DPSIR-framework, it is important to note that the basic concept originates from rationalist ideas of cognitive mapping (Axelrod, 1976). That is, it assumes that stakeholders are more interested in rational decisions rather than in biasing outcomes towards political or personal benefit. For the purpose of supporting such rational choices, the framework seeks to structure diffuse decision-making problems into a strategic course of action or storyline. This means that the framework tries to help decision-makers to specify their political targets and to structure the course of action along a strategic or causal sequence of decision-making steps. These decision-making steps are then informed by specific variables arranged along that sequence. By these variables, the DPSIR framework may then provide answers on optimal choices when they are used as an input for mathematical modelling of decision-making scenarios (Wolfslehner et al., 2011; Mendoza et al., 2006; Marcot et al., 2012; Ascough II et al., 2008). 
The following examples explain the construction of such storylines in more detail and illustrate how forest variables might be arranged along such a logical sequence of steps: Generally speaking, the basic arrangement of indicators follows the assumption that rational policy makers are not only interested in the current state of ecological systems (as they are typically measured by NFIs) but also in its social and economic implications. For this purpose, as shown by Figure 12, the framework constructs a bridge between social and ecological systems, i.e. it constructs storylines of cause-effect relationships between human behaviour, the environmental status and the provision of ecosystem services. The characteristics of social and ecological systems are, of course, very complex and might be measured by many different variables. For this reason, the framework categorises variables into so-called "drivers", "pressures", "states", "impacts" and "responses" (DPSIR) and organises them in the sequence of a causal chain. In such chain, social or economic components such as the demand for wood products are considered to be "drivers" (D). These have an effect on "pressures" (P) such as human-induced activities (e.g. forest management with clear cut). These pressures could be seen as most important for decision makers because they describe activities and management practices that may be regulated actively via new forest policies. The following variables within the chain then describe the effects of such management strategies. Such variables comprise effects on the environmental "state" (S) such as the forest area. These states in turn lead to measureable "impacts" on the provision of forest-related goods and services. These impacts could then be seen as the targeted effect of a political decision because they describe effects that feed back into the social system and provide a benefit to livelihoods and wellbeing. Finally, a change in the state of wellbeing and livelihoods leads to a response of the social system. This is the stage where policy makers may actively influence the socio-ecological system by policy making. Thus policy makers might "respond" by taxation of the timber market which will eventually regulate "drivers", i.e. the demand for timber. In combination, if used in mathematical modelling (cf. Wolfslehner et al., 2011; Mendoza et al., 2006; Marcot et al., 2012; Ascough II et al., 2008), such frameworks may eventually predict the ecological, economic and social consequences of a decision option. This potential to combine and predict also renders the advantage of the framework, which is its ability to provide a holistic overview on decision-making effects on all thematic levels. Based on the predicted effects, it eventually provides policy advice on how to address social and environmental issues holistically and strategically.

Until now, many monitoring and reporting processes have successfully used such frameworks for the selection of indicators and variables: The OECD (1993) has introduced the idea of the 
basic PSR-framework as a guideline to help the strategic selection of measureable attributes alongside socio-environmental cause-effect relationships. Other indicator processes have later extended the basic framework to the DPSIR framework (CBD, 1997; Smeets and Weterings, 1999) which is now a well-established tool for environmental reporting purposes.

Also in the course of my study I could observe that reporting processes of EEA and CBD, have structured their reporting formats around the DPSIR framework. Processes of reporting sustainable forest management under FAO allow such structuring but do not yet apply them operationally for analytic and communicative purposes (Wolfslehner and Vacik, 2011; EFI, 2013). I would recommend to take the idea to the next level and to apply the framework for analytic purposes. By example of methods already applied in decision making research (e.g. Wolfslehner and Vacik, 2011; Mendoza et al., 2006; Marcot et al., 2012; Ascough II et al., 2008) and using data from the various monitoring processes, such analysis could predict decision-making scenarios and thus provide policy-makers with valuable storylines how the change in a given variable (e.g. regulation of "pressures" through taxation) might affect other components of the system (e.g. the "state" of forest biodiversity and its "impact" on the provision of ecosystem services).

Finally, besides communication via the DPSIR framework, the observation of reporting processes to CBD (Chapter 5), leads to conclude that it is important to communicate the scientific message by suitable providers. I have observed that the best mediator for such information and policy advice were institutions with a long-established relationship of trust. Examples were ENGOs for the Convention of Biological Diversity, and the sectoral governmental research agencies (forestry vs. conservation) for their parent ministries. Such researchers benefited from their political involvement in political questions, their mandates and their regular communication via reports to the government. University research in contrast was generally not consulted directly. We may conclude that such traditional research may influence decision making-process best via departmental research institutions. Subcontracts and governmental research funds that are targeted towards specific policy needs and decision-making issues provide the financial instruments and options for university research to streamline research efforts, respond to policy questions and to inform decision-making processes more effectively. 


\subsection{The risk of political bias and options to protect scientific credibility}

Above, I have suggested ideas of how to improve inventory designs and how to communicate scientific evidence for well-informed decision making. Yet if the objective is to be both, scientifically credible and politically relevant, then it is not enough for inventory specialists to understand and account for policy-making issues and data requirements only. When entering into the domain of political issues and interest, scientists also need to be aware of the risks to scientific credibility (Guldin, 2003, Mills and Clark, 2001).

Previous research suggests that such risks exist especially in the context of international reporting commitments (Stevanov et al., 2013; Böcher and Krott, 2010; Krott, 2012). The reason is that the relevant departmental research agencies are mandated and funded by governmental authorities. Departmental inventory research is therefore often assumed to be located in a conflict zone of the policy-science interface where political interests are likely to oppose scientific neutrality. This might be the case when scientific results are at odds with a politically favored outcome and when scientific results reveal that policy makers did not succeed in meeting political commitments such as the protection of forests. Also Böcher and Krott (2010) illustrate the dichotomy by their "Research, Implementation and Utilisation" (RIU) model which defines policy advice by constant interaction between "Science" and "Political Practice". There is an assumed risk in that interaction because powerful political actors are believed to actively and intentionally influence research output or to select information for specific pre-defined political interests and purposes (Krott, 2012, Haas, 2004). Due to that interaction and mutual dependency many authors have referred to the "politicization of science" (Weingart, 1982, Pielke, 2002, Pielke, 2004, Pielke, 2007, Sarewitz, 2010) or, more specifically, the "politicization of forestry" (Krott, 2012). The general assumption is that scientific research is politically influenced or "tainted" (Haas, 2004) such as to produce information that is biased towards a politically favoured outcome (Risse, 2004; Hertin et al., 2009; Krott, 2012; Pregernig, 2007). Due to these perceptions my second research objective was to identify instances where the monitoring and reporting process may be perceived susceptive to political bias and to make scientist aware of the associated risks.

For this purpose, I identified stakeholders involved in the data generation process and I validated two hypotheses that were generally considered important by authors supporting the theory of political bias: (1) political interest (rather than scientific ones) and (2) nontransparent assessment rules (as a means to disguise political influence). In combination the 
two criteria revealed if non-transparent rules (of measurement, assessment and interpretation) allowed stakeholders to bias information towards a politically favored outcome. I located such risks within two domains of the data generation process: (I) within scientific responsibilities (measurement, assessment and reporting) and (II) within political responsibilities (data interpretation and decision making). The analysis spanned biodiversity reporting processes at three spatial scales: National reports under EC Habitats Directive (national), as well as by the secretariats of the EC (European) and the UN (global).

In the domain of political responsibilities, the study identified potential sources of political bias. In this context, it was interesting to see that such biased statements were generally contested. In fact, the study has indicated that parliamentarians generally found transparent information to be more convincing. Indeed, empty assumptions without verifiable evidence were less convincing to parliamentarians and frequently failed to reach consent. Politicians even actively addressed the issue of non-transparency and data gaps on topics such as "sustainable forest management" and "near-natural forest areas" by extending the inventory mandate. This observation showed the political acknowledgement of scientific information and a will to improve the knowledge base for fully informed decision-making. On the principle of more comprehensive and sample-based information, they wanted to support implementation of existing policies such as the management standards as discussed under UNFF and the wilderness targets of the National Forest Strategy and the National Biodiversity Strategy.

Even though I could not find compelling evidence of a biased decision making process within the domain of political responsibilities, I made different observations in the domain of scientific responsibilities at the lowest level of monitoring and reporting process, i.e. at the measurement stage. Yet the observations were heterogeneous, meaning that most (but not all) technical steps of data acquisition are without risks to perceptions of political bias. At the upper levels of the UN and the EC, my analysis did not identify non-transparent reporting processes that could have allowed political interests to influence assessment results. Instead both, the EC and the UN quoted all of the consulted sources adequately when they compiled reports under obligations of CBD. The background data was therefore found to be transparent and verifiable, meaning that there were few options (as mentioned below) to hide unwanted evidence and to tacitly bias or influence results.

This conclusion however does not try to indicate that there was absolutely no way for political interests to tacitly influence information on the lower levels of the data generation process. In 
fact, within national reports of one case study country (cf. Ch. 4), the law allows that some data be compiled by measurements from sub-national programmes and potentially from forest owners (State-specific habitat monitoring programmes). Here, I did observe potential risks of tacit influence or bias. The source was at the basic stage of sample selection and measurement. Here, the problem was that, according to the legal framework, data produced by forest owners could have potentially contributed to the national databases of EU habitat areas. This is according to the country's Federal Conservation Act (BNatSchG), which makes forest owners responsible for monitoring obligations under intervention provisions of $\S \S 13$, a regulation that also obliges land owners to pay for measures of compensation and mitigation in case of management-induced disturbances in natural systems. The motivation to avoid such costs could possibly motivate stakeholders to produce biased assessments that hide unwanted evidence of EU-habitat types. In addition, the fact that the identification and official registration of habitat types further leads to entitlement of specific EU funds under compensation schemes the Common Agricultural Policy (CAP) may further motivate landowners to specific measurements. These may either over- or underestimate the area of habitat types, depending on the owners' expectations or business strategy towards EU-funds.

It is interesting to see that, in spite of the described problems of political bias being associated with ambiguity and sample selection, States insisted that their databases be used for reporting purposes under Habitats Directive. According to one interview, in the course of drafting reports under Article 17 Habitats Directive, pilot studies revealed that State programmes even tended to produce smaller area estimates than the respective assessments of NFI. States still insisted on the use of their data and their way of defining habitat types (Schmitz, 2015, personal communication).

There might be political or scientific reasons for that preference. One was discussed in Chapter 6.2.4 and relates to the need to have spatially explicit information and the generally held assumption that States'-programmes provided more accurate information. Yet, given that data provided by the Federal States, their sources, assessment- and measurement methods were not always transparent (cf. Chapter 4), political motivations to hide unwanted evidence of habitat areas could also be plausible. At least, according to my evidence, most Federal States did not provide a comprehensive report transparently detailing the methods of habitat area assessments, ranging from inventory design, variables to be measured and analytic methods. Following these manuals, also sample selection for area assessments is not defined. Instead, there is a theoretical option to steer sample selection towards known habitat areas. 
Then, such selection could lead to smaller area estimates because it disguised evidence of habitats outside such known areas. Another reason of smaller area estimates in State programmes (as opposed to NFI) could be the assessment of such areas in the framework of

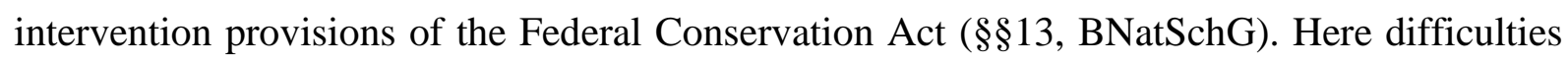
with ambiguous habitat keys allow interpretations favouring tighter habitat identification rules, thus leading to lesser areas being identified, and consequently, lesser areas needing protection under such regulations.

The dispute on the so-called "shadow-lists" has shown that such ambiguity of definitions is also a problem for legal certainty, especially when ambiguous keys lead to different interpretations and allow political interests to bias or influence results, depending on stakeholders' motivation and expectations towards forests. Shadow-lists were based on assessments made by ENGOs and compile areas that classify as EU forest habitat types under a biodiversity conservation point-of-view (cf. for instance the shadow-list for Poland: in Pawlaczyk et al. (2004)). Such lists enclosed habitat types that remained hidden from governmental assessments and raised criticism about the validity of the government's proposed sites for designation under the Natura 2000 network, the so-called "proposed sites of community interest" (pSCI). Thus, in the course of the European evaluation, the ENGO's national shadow lists and their habitat inventories eventually played a pivotal role in exerting political pressure and political pressure pushed governments towards the more extensive recognition of EU forest habitat types entitled for protection under the Natura 2000 network of special areas of conservation (SAC) (cf. Weber et al., 2002; Evans, 2012). This example shows that different estimates and unresolved issues about definitions may imply legal uncertainties about accurate and precise estimates. Powerful or actors may then succeed with putting preferred data sources at the forefront of the political agenda (Krott et al., 2014).

If the objective is to remove such discrepancies between different assessments and to avert the risk of political bias, then it is important to address its source. In the German habitat mapping programme, the technical key to allow political interests to influence measurements and monitoring results was lack of transparency within the administrative process of identifying and mapping EU-habitat types at the State-level. According to my observations, Federal States did not provide a rigorously standardized and precise definition of variables, threshold values and algorithms that may unambiguously identify such areas. Instead, assessors might skew inventory rules and define their own habitat area indicators. Ambiguity therefore 
provided opportunities for politically biased interpretations and measurements that hid unwanted evidence.

These observations lead to the question if transparent methods of area assessments, as they are already employed by German NFI assessments, could be used more comprehensively in reporting processes such as to produce more verifiable and transparent biodiversity reports. My study has indicated that NFI might improve its utility in reporting processes if it was adapted to better meet data requirements of strategic policy targets (the UN's CBD, the ECHabitats Directive, national discourses on good practice in forest management). Possible improvements have been mentioned in Chapters 6.2.2 - 6.2.5. These include the extension of field protocols towards variables of biodiversity interest (flora and fauna) and an adapted sampling and plot design to increase inclusion probability of rare events. In such an approach more intensive sampling may be assisted by remote sensing and stratification that guides monitoring effort towards sites with potential occurrence of uncommon habitat types. Harmonisation with the European infrastructure of Level I plots (ICP forests programme) may further replace qualitative expert opinion by scientific and standardised measurements that improve the estimation of human-induced and natural threats to ecosystems.

Besides the removal of problems with transparency and the option of political influence, another option to limit the risk of political bias is certainly the avoidance of conflict between the political interests and scientific responsibilities. A possible option would be better coordination between existing programmes of ministerial resorts and the centralization of monitoring responsibilities to research institutes or administrative bodies without stakes in land-use rights or forest funds. Other options to protect scientific credibility are additional and long-term research funds and active support of scientific scrutiny. A focus on scientific publishing and peer-review could be a means to maintain the scientific discourse and quality standards. Sweden has already implemented such a system where an independent research institution is in charge of monitoring responsibilities: Though the university was mandated by a ministry and partly depended on state funding, the financial support of new research and pilot projects on inventory techniques was mainly independent. The university has further published its research in peer-reviewed journals which enables the scientific community to scrutinize and improve inventory techniques.

Since the centralization of some biodiversity assessments from the States to the Federation and the extension of the NFI mandate towards assessments that are relevant for cooperative reporting of ministerial resorts to the Habitats Directive, we can see similar trends in 
Germany. Especially, stronger ties to the scientific community now guarantee scientific credibility by constant and active peer review. The implementation of the new mandate is however incomplete. Habitat area assessments are still overseen by Federal States because neither BfN, nor TI has a mandate to dictate precise habitat area indicators to the States. As a result, most relevant information, i.e. habitat area assessments, that come with monetary implications are often still carried out by States, which may also use data provided by landowners (during procedures of drafting Natura 2000 management plans or compensation measures). The interests of land-owners, however, might be in conflict with monitoring results because area assessments of habitat types still lead to the obligation to protect those sites and usually produce a monetary burden. For this reason, potentially, there could be an interest to hide unwanted evidence of habitat types outside the area of the Natura 2000 network of protected sites.

The implications of such conflicts become evident by the example of a ruling by the European Court of Justice in 2001. As detailed in Box 12, the court ruled that Germany failed to protect its complete set of European habitat areas. Germany was also prosecuted for its failure to implement nationally standardised and transparent monitoring and reporting systems. This ruling later led to extensive improvements of the $M \& R$ process, including harmonisation of the Federal assessment methods regarding "structures and functions" of habitat types. Yet, my thesis has found that for "area" assessments at the State level, there were still inconsistencies and ambiguous assessment rules that could allow conflicts of interest to tacitly bias results. Ideally, from a scientific perspective, also these assessments shall be harmonised by a national mandate and conducted under authority of independent institutes that have no stake in land-use rights and are not affected by management regulations. 
"The Commission states that it instituted the present proceedings with a view to securing a declaration that the German national list was manifestly inadequate, and that such inadequacy far exceeded the margin of discretion conferred on Member States. Such inadequacy is evident with regard to the situation existing when the period set in the reasoned opinion expired, and even though the German authorities have, since then, forwarded several other lists of sites, the infringements of which they stand accused still persist. The Commission submits in this connection that a comparison between the proposals of the German authorities and the scientific data provided by those authorities, in particular the manual entitled 'Das europäische Schutzgebietssystem Natura 2000' edited by the Bundesamt für Naturschutz (Federal Office for Nature Protection) amply demonstrates the true nature of those infringements. The German national list does not therefore, in the Commission's opinion, satisfy the criteria referred to in Article 4(1) of the directive, read in conjunction with Annex III thereto."

(European Court of Justice judgment of 11. 9. 2001 - CASE C-71/99,paragraph 21)

Box 12. Excursus on the ruling of the European Court of Justice on 11. 9. 2001 - CASE C$71 / 99$

Recommendations from the German Advisory Council on the Environment (SRU, 2000, p.m. 14/3363) to the government indicate that a similar discussion on the shift of responsibilities has already started some years ago. The SRU report (SRU, 2000, p.m. 14/3363) took note of potential conflicts that may arise when monitoring and utilitarian responsibilities are held by one single institution (p.72, Section 213$)^{2}$. Therefore, SRU recommended that responsibilities shall be separated. In such a scenario, forest management and other utilitarian responsibilities would be gradually transferred to the private sector, which meant that public forests would be progressively converted to private forests ${ }^{22}$. On the other hand, the report also appreciated the value of monitoring activities, both within the BMEL's NFI (p. 27, Section 212) and the

\footnotetext{
22 "Regarding sovereign tasks, there are conflicts of interest and overlaps between forestry and nature conservation, which are not yet adequately organised from an technical and objective perspective. As a solution, the German Advisory Council on the Environment recommends to separate sovereign tasks and utilitarian interests fundamentally. In a long term, this would lead to establishing a forest administration that solely takes charge of sovereign tasks. Since it would be largely relieved from conflicts of interest, it could also represent nature conservation interests by equal emphasis; conflicts of competence between bureaucracies of forestry and nature conservation would be widely defused. In this concept the entire public forest would be successively privatised or at least managed privately." (translated by the author from original in: SRU, 2000, p.m. 14/3363, p. 72, Section 213)
} 
BMU's biodiversity monitoring programme (p.110, section 72). It therefore advised the government, that such sovereign tasks of monitoring and supervision of private forestry activities should be the task of a coalition of independent bureaucracies. In that context, SRU also took note of institutional struggles that might hinder the establishment of such a coalition. Thus SRU recommended that the sectoral bureaucracies of forest- and conservation agencies under the resorts of BMEL and BMU would be unchained from utilitarian interests. Being independent from such economic interests, SRU assumed that institutional struggles for competence could be resolved. Then it would be possible for the resorts to reconcile controversies (p.72, Section 211,213), to cooperate in a coalition and to jointly monitor and oversee forest management actives.

It is to note however, that in spite of the SRUs proposal for ministries to cooperate for monitoring proposes and its influence on past decision-making processes (cf. parliamentary process in Chapter 3) the institutional cooperation that followed, resulted in controversial discussions about definitions when BMEL and BMU jointly streamlined NFI 3 and the assessments of European habitat types for reporting to Article 17, Habitats Directive (Schmitz, 2015 personal communication).

Indeed, the redistribution and coordination of responsibilities between the ministries also means a need for compromise on the definitions of variables where perceptions are either more steered towards utilitarian (BMEL) or biodiversity conservation interests (BMU). Eventually, a shift of monitoring responsibilities also means a shift of powers between disciplines of biodiversity conservation and forestry. Some authors claim that such a shift is not politically wanted and that ministries rather want to protect and possibly extend their governmental influence (Giessen et al., 2014). In Germany, the BMU has raised ambitions to soften the departmental principle of the constitutional law (Article 65, sentence 2) and planned to push for a right of initiative that would allow BMU to make decisions within the department of BMEL (BMUB, 2016). Environmental interests would then play a larger role in forest-policy decisions and diversify the questions addressed by forest policy. It is eventually the decision of both resorts to decide on the extent to which cooperation is actually wanted.

Not only political disputes are involved in the distribution of monitoring responsibilities. Also professional and occupational disputes play an important role. A biologist for instance criticised the competence of forest inventory specialists to accurately identify forest species (Froehlich-Schmidt, 2011). The redistribution of monitoring responsibilities is eventually a 
double-edged decision typical to national monitoring programmes, where science may contribute technical knowledge and advice, but the mandate, the distribution of funds and administrative responsibilities is eventually a political decision. Political disputes over the prioritisation of topics, the distribution of budgets, personal and influence, as they are typical for such political decisions (Giessen et al., 2014), could mean that there is still some way to go before a compromise is being achieved. 
Annex I: The 20 Aichi targets as defined by the global strategic plan for Biodiversity 2011-2020 (UNEP/CBD/COP decision X/2 (2010))

\begin{tabular}{|c|c|}
\hline Strategic goal A: & $\begin{array}{l}\text { Address the underlying causes of biodiversity loss by mainstreaming biodiversity } \\
\text { across government and society }\end{array}$ \\
\hline Target 1: & $\begin{array}{l}\text { By } 2020 \text {, at the latest, people are aware of the values of biodiversity and the steps } \\
\text { they can take to conserve and use it sustainably. }\end{array}$ \\
\hline Target 2: & $\begin{array}{l}\text { By } 2020 \text {, at the latest, biodiversity values have been integrated into national and local } \\
\text { development and poverty reduction strategies and planning processes and are being } \\
\text { incorporated into national accounting, as appropriate, and reporting systems. }\end{array}$ \\
\hline Target 3: & $\begin{array}{l}\text { By 2020, at the latest, incentives, including subsidies, harmful to biodiversity are } \\
\text { eliminated, phased out or reformed in order to minimize or avoid negative impacts, } \\
\text { and positive incentives for the conservation and sustainable use of biodiversity are } \\
\text { developed and applied, consistent and in harmony with the Convention and other } \\
\text { relevant international obligations, taking into account national socio-economic } \\
\text { conditions. }\end{array}$ \\
\hline Target 4: & $\begin{array}{l}\text { By 2020, at the latest, Governments, business and stakeholders at all levels have taken } \\
\text { steps to achieve or have implemented plans for sustainable production and } \\
\text { consumption and have kept the impacts of use of natural resources well within safe } \\
\text { ecological limits. }\end{array}$ \\
\hline Strategic goal B: & Reduce the direct pressures on biodiversity and promote sustainable use \\
\hline Target 5: & $\begin{array}{l}\text { By } 2020 \text {, the rate of loss of all natural habitats, including forests, is at least halved and } \\
\text { where feasible brought close to zero, and degradation and fragmentation is } \\
\text { significantly reduced. }\end{array}$ \\
\hline Target 6: & $\begin{array}{l}\text { By } 2020 \text { all fish and invertebrate stocks and aquatic plants are managed and harvested } \\
\text { sustainably, legally and applying ecosystem based approaches, so that overfishing is } \\
\text { avoided, recovery plans and measures are in place for all depleted species, fisheries } \\
\text { have no significant adverse impacts on threatened species and vulnerable ecosystems } \\
\text { and the impacts of fisheries on stocks, species and ecosystems are within safe } \\
\text { ecological limits. }\end{array}$ \\
\hline Target 7: & $\begin{array}{l}\text { By } 2020 \text { areas under agriculture, aquaculture and forestry are managed sustainably, } \\
\text { ensuring conservation of biodiversity. }\end{array}$ \\
\hline Target 8: & $\begin{array}{l}\text { By } 2020 \text {, pollution, including from excess nutrients, has been brought to levels that } \\
\text { are not detrimental to ecosystem function and biodiversity. }\end{array}$ \\
\hline Target 9: & $\begin{array}{l}\text { By } 2020 \text {, invasive alien species and pathways are identified and prioritized, priority } \\
\text { species are controlled or eradicated, and measures are in place to manage pathways } \\
\text { to prevent their introduction and establishment. }\end{array}$ \\
\hline Target 10: & $\begin{array}{l}\text { By } 2015 \text {, the multiple anthropogenic pressures on coral reefs, and other vulnerable } \\
\text { ecosystems impacted by climate change or ocean acidification are minimized, so as to } \\
\text { maintain their integrity and functioning. }\end{array}$ \\
\hline Strategic goal C: & $\begin{array}{l}\text { Improve the status of biodiversity by safeguarding ecosystems, species and genetic } \\
\text { diversity }\end{array}$ \\
\hline Target 11: & $\begin{array}{l}\text { By 2020, at least } 17 \text { per cent of terrestrial and inland water areas, and } 10 \text { per cent of } \\
\text { coastal and marine areas, especially areas of particular importance for biodiversity } \\
\text { and ecosystem services, are conserved through effectively and equitably managed, } \\
\text { ecologically representative and well connected systems of protected areas and other } \\
\text { effective area-based conservation measures, and integrated into the wider landscapes } \\
\text { and seascapes. }\end{array}$ \\
\hline
\end{tabular}




\begin{tabular}{|c|c|}
\hline Target 12: & $\begin{array}{l}\text { By } 2020 \text { the extinction of known threatened species has been prevented and their } \\
\text { conservation status, particularly of those most in decline, has been improved and } \\
\text { sustained. }\end{array}$ \\
\hline Target 13: & $\begin{array}{l}\text { By } 2020 \text {, the genetic diversity of cultivated plants and farmed and domesticated } \\
\text { animals and of wild relatives, including other socio-economically as well as culturally } \\
\text { valuable species, is maintained, and strategies have been developed and implemented } \\
\text { for minimizing genetic erosion and safeguarding their genetic diversity. }\end{array}$ \\
\hline Strategic goal D: & Enhance the benefits to all from biodiversity and ecosystem services \\
\hline Target 14: & $\begin{array}{l}\text { By 2020, ecosystems that provide essential services, including services related to } \\
\text { water, and contribute to health, livelihoods and well-being, are restored and } \\
\text { safeguarded, taking into account the needs of women, indigenous and local } \\
\text { communities, and the poor and vulnerable. }\end{array}$ \\
\hline Target 15: & $\begin{array}{l}\text { By 2020, ecosystem resilience and the contribution of biodiversity to carbon stocks } \\
\text { has been enhanced, through conservation and restoration, including restoration of at } \\
\text { least } 15 \text { per cent of degraded ecosystems, thereby contributing to climate change } \\
\text { mitigation and adaptation and to combating desertification. }\end{array}$ \\
\hline Target 16: & $\begin{array}{l}\text { By } 2015 \text {, the Nagoya Protocol on Access to Genetic Resources and the Fair and } \\
\text { Equitable Sharing of Benefits Arising from their Utilization is in force and operational, } \\
\text { consistent with national legislation. }\end{array}$ \\
\hline Strategic goal E: & $\begin{array}{l}\text { Enhance implementation through participatory planning, knowledge management } \\
\text { and capacity building }\end{array}$ \\
\hline Target 17: & $\begin{array}{l}\text { By } 2015 \text { each Party has developed, adopted as a policy instrument, and has } \\
\text { commenced implementing an effective, participatory and updated national } \\
\text { biodiversity strategy and action plan. }\end{array}$ \\
\hline Target 18: & $\begin{array}{l}\text { By } 2020 \text {, the traditional knowledge, innovations and practices of indigenous and local } \\
\text { communities relevant for the conservation and sustainable use of biodiversity, and } \\
\text { their customary use of biological resources, are respected, subject to national } \\
\text { legislation and relevant international obligations, and fully integrated and reflected in } \\
\text { the implementation of the Convention with the full and effective participation of } \\
\text { indigenous and local communities, at all relevant levels. }\end{array}$ \\
\hline Target 19: & $\begin{array}{l}\text { By } 2020 \text {, knowledge, the science base and technologies relating to biodiversity, its } \\
\text { values, functioning, status and trends, and the consequences of its loss, are improved, } \\
\text { widely shared and transferred, and applied. }\end{array}$ \\
\hline Target 20: & $\begin{array}{l}\text { By } 2020 \text {, at the latest, the mobilization of financial resources for effectively } \\
\text { implementing the Strategic Plan for Biodiversity } 2011-2020 \text { from all sources, and in } \\
\text { accordance with the consolidated and agreed process in the Strategy for Resource } \\
\text { Mobilization should increase substantially from the current levels. This target will be } \\
\text { subject to changes contingent to resource needs assessments to be developed and } \\
\text { reported by Parties. }\end{array}$ \\
\hline
\end{tabular}




\section{Annex II: Indicators of the Initiative "Streamlining European Biodiversity}

\section{Indicators" (SEBI)}

Source: EC (2014): Fifth report of the European Union to the Convention on Biological Diversity.

\begin{tabular}{|c|c|c|}
\hline $\begin{array}{l}\text { EU- } \\
\text { ID }\end{array}$ & Title of EU SEBI indicators & $\begin{array}{l}\text { Directly relevant for forests } \\
\text { (indicators referring to forest } \\
\text { areas) }\end{array}$ \\
\hline 01 & Abundance and distribution of selected species & $\mathrm{X}$ \\
\hline 02 & Red List Index for European species & $\mathrm{X}$ \\
\hline 03 & Conservation status of species of European interest & $\mathrm{X}$ \\
\hline 04 & Ecosystem coverage (including forest areas) & $\mathrm{X}$ \\
\hline 05 & Conservation status of habitats of European interest & $\mathrm{x}$ \\
\hline 06 & Livestock genetic diversity & \\
\hline 07 & Nationally designated protected areas & $\mathrm{X}$ \\
\hline 08 & Sites designated under EU Habitats and Birds Directive & $\mathrm{x}$ \\
\hline 09 & Critical load exceedance for nitrogen & \\
\hline 10 & Invasive alien species in Europe & \\
\hline 11 & Impact of climatic change on bird populations & \\
\hline 12 & Marine Trophic Index of European seas & \\
\hline 13 & Fragmentation of natural and semi-natural areas & $\mathrm{X}$ \\
\hline 14 & Fragmentation of river systems (in preparation) & \\
\hline 15 & Nutrients in transitional, coastal and marine waters & \\
\hline 16 & Freshwater quality & \\
\hline 17 & Forest growing stock, increment and fellings & $\mathrm{X}$ \\
\hline 18 & Forest: deadwood & $\mathrm{X}$ \\
\hline 19 & Agriculture: nitrogen balance & \\
\hline 20 & Agriculture: area under management practices potentially supporting biodiversity & \\
\hline 21 & Fisheries: European commercial fish stocks & \\
\hline 22 & Aquaculture: effluent water quality from finfish farms & \\
\hline 23 & Ecological Footprint of European countries & \\
\hline 24 & Patent applications based on genetic resources & \\
\hline 25 & Financing biodiversity management & \\
\hline 26 & Public awareness & \\
\hline
\end{tabular}




\section{Annex III: Pan-European Criteria and Indicators from 7th Ministerial}

\section{Conference of Forest Europe in Madrid, 2015}

\begin{tabular}{|c|c|c|}
\hline $\begin{array}{l}\text { Criterion } \\
\text { (general target) }\end{array}$ & $\begin{array}{l}\text { Indicator } \\
\text { (to be reported) }\end{array}$ & $\begin{array}{l}\text { Description } \\
\text { (refers to potential variables to be measured) }\end{array}$ \\
\hline \multicolumn{3}{|c|}{$\begin{array}{l}\text { C.1 Policies, institutions and instruments to maintain and appropriately enhance forest resources and their } \\
\text { contribution to global carbon cycles }\end{array}$} \\
\hline & 1.1 Forest area & $\begin{array}{l}\text { Area of forest and other wooded land, classified by forest type } \\
\text { and by availability for wood supply, and share of forest and } \\
\text { other wooded land in total land area. }\end{array}$ \\
\hline & 1.2 Growing Stock & $\begin{array}{l}\text { Growing stock on forest and other wooded land, classified by } \\
\text { forest type and by availability for wood supply. }\end{array}$ \\
\hline & $\begin{array}{l}\text { 1.3 Age structure and/or } \\
\text { diameter distribution }\end{array}$ & $\begin{array}{l}\text { Age structure and/or diameter distribution of forest and other } \\
\text { wooded land, classified by availability for wood supply. }\end{array}$ \\
\hline & 1.4 Forest carbon & $\begin{array}{l}\text { Carbon stock and carbon stock changes in forest biomass, } \\
\text { forest soils and in harvested wood products }\end{array}$ \\
\hline \multicolumn{3}{|c|}{ C.2 Policies, institutions and instruments to maintain forest ecosystem health and vitality } \\
\hline & $\begin{array}{l}2.1 \text { Deposition and } \\
\text { concentration of air } \\
\text { pollutants }\end{array}$ & $\begin{array}{l}\text { Deposition and concentration of air pollutants on forest and } \\
\text { other wooded land }\end{array}$ \\
\hline & 2.2 Soil condition & $\begin{array}{l}\text { Chemical soil properties }(\mathrm{pH}, \mathrm{CEC}, \mathrm{C} / \mathrm{N} \text {, organic } \mathrm{C} \text {, base } \\
\text { saturation) on forest and other wooded land related to soil } \\
\text { acidity and eutrophication, classified by main soil types }\end{array}$ \\
\hline & 2.3 Defoliation & $\begin{array}{l}\text { Defoliation of one or more main tree species on forest and } \\
\text { other wooded land in each of the defoliation classes }\end{array}$ \\
\hline & 2.4 Forest damage & $\begin{array}{l}\text { Forest and other wooded land with damage, classified by } \\
\text { primary damaging agent (abiotic, biotic and human induced) } \\
\text { and by forest type }\end{array}$ \\
\hline & $\begin{array}{l}2.5 \text { Forest land } \\
\text { degradation }\end{array}$ & Trends in forest land degradation \\
\hline \multicolumn{3}{|c|}{ C.3 Policies, institutions and instruments to maintain and encourage the productive functions of forests } \\
\hline & 3.1 Increment and fellings & $\begin{array}{l}\text { Balance between net annual increment and annual fellings of } \\
\text { wood on forest available for wood supply }\end{array}$ \\
\hline & 3.2 Roundwood & Quantity and market value of roundwood \\
\hline & 3.3 Non-wood goods & $\begin{array}{l}\text { Quantity and market value of non-wood goods from forest and } \\
\text { other wooded land }\end{array}$ \\
\hline & 3.4 Services & Value of marketed services on forest and other wooded land \\
\hline \multicolumn{3}{|c|}{$\begin{array}{l}\text { C.4 Policies, institutions and instruments to maintain, conserve and appropriately enhance the biological } \\
\text { diversity in forest ecosystems }\end{array}$} \\
\hline & $\begin{array}{l}\text { 4.1 Diversity of tree } \\
\text { species }\end{array}$ & $\begin{array}{l}\text { Area of forest and other wooded land, classified by number of } \\
\text { tree species occurring }\end{array}$ \\
\hline & 4.2 Regeneration & $\begin{array}{l}\text { Total forest area by stand origin and area of annual forest } \\
\text { regeneration and expansion }\end{array}$ \\
\hline & 4.3 Naturalness & Area of forest and other wooded land by class of naturalness \\
\hline & $\begin{array}{l}4.4 \text { Introduced tree } \\
\text { species }\end{array}$ & $\begin{array}{l}\text { Area of forest and other wooded land dominated by } \\
\text { introduced tree species }\end{array}$ \\
\hline & 4.5 Deadwood & $\begin{array}{l}\text { Volume of standing deadwood and of lying deadwood on } \\
\text { forest and other wooded land }\end{array}$ \\
\hline & 4.6 Genetic resources & $\begin{array}{l}\text { Area managed for conservation and utilisation of forest tree } \\
\text { genetic resources (in situ and ex situ genetic conservation) and } \\
\text { area managed for seed production }\end{array}$ \\
\hline & 4.7 Forest fragmentation & $\begin{array}{l}\text { Area of continuous forest and of patches of forest separated } \\
\text { by non-forest lands }\end{array}$ \\
\hline & $\begin{array}{l}\text { 4.8 Threatened forest } \\
\text { species }\end{array}$ & $\begin{array}{l}\text { Number of threatened forest species, classified according to } \\
\text { IUCN Red List categories in relation to total number of forest }\end{array}$ \\
\hline
\end{tabular}




\begin{tabular}{|l|l|}
\hline & species \\
\hline 4.9 Protected forests & $\begin{array}{l}\text { Area of forest and other wooded land protected to conserve } \\
\text { biodiversity, landscapes and specific natural elements, } \\
\text { according to MCPFE categories }\end{array}$ \\
\hline $\begin{array}{l}\text { 4.10 Common forest bird } \\
\text { species }\end{array}$ & $\begin{array}{l}\text { Occurrence of common breeding bird species related to forest } \\
\text { ecosystems }\end{array}$ \\
\hline
\end{tabular}

C.5 Policies, institutions and instruments to maintain and appropriately enhance of the protective functions in forest management

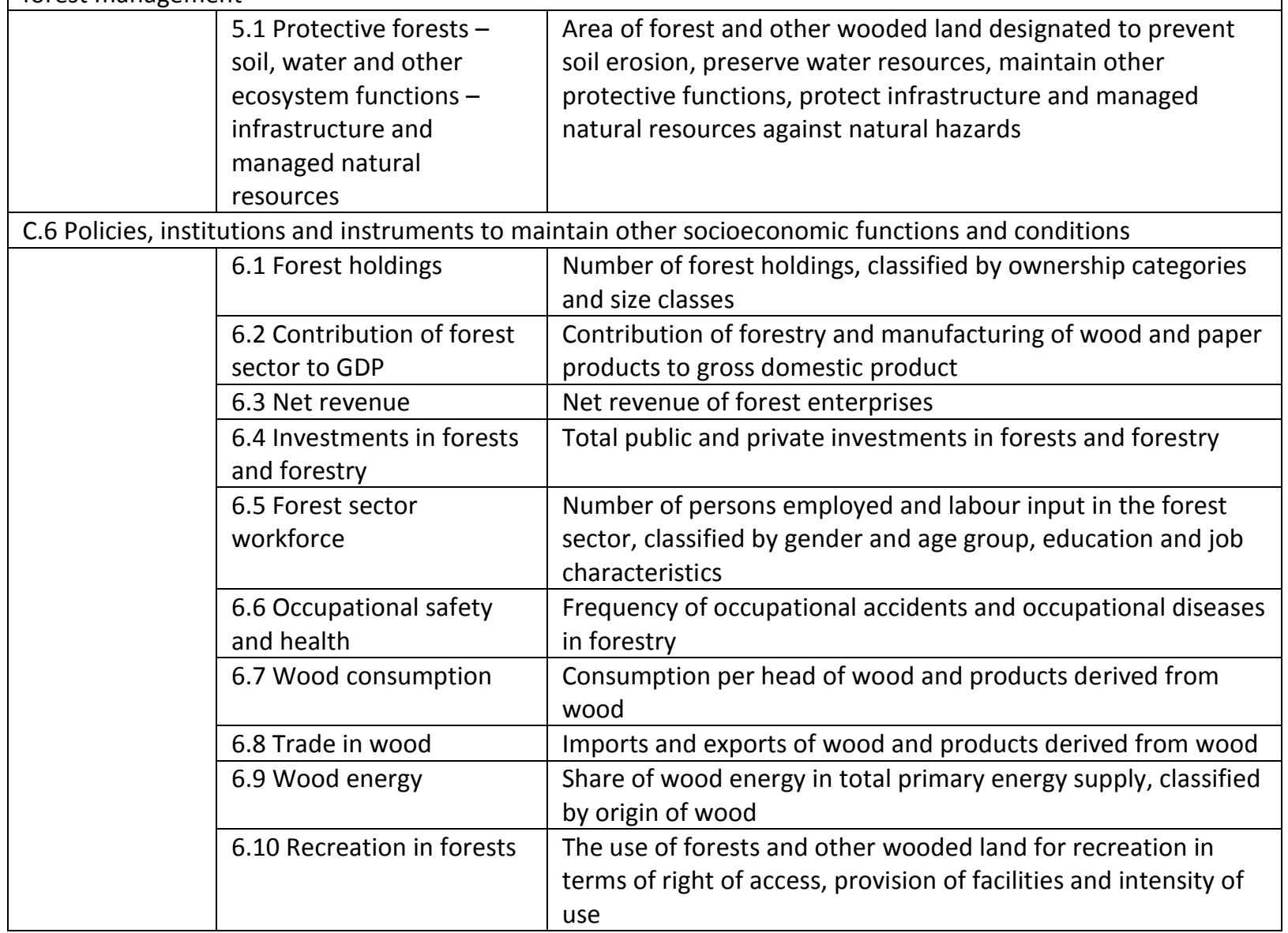




\section{Annex IV: Policy-targets on "Sustainable Forest Management" by UNFF}

The "Non-Legally Binding Instrument on All Types of Forests" was adopted by the 7th meeting of UNFF and the Member states of the United Nations (UN) (ECOSOC resolution 2007/40) and endorsed the concept of SFM as defined by the UNFF's „Four Global Objectives on Forests" in Section IV and the "Seven Thematic Elements on Sustainable Forest Management" in Section V (ECOSOC resolution 2007/40). These had been structured around the pan-European indicators defined by MCPFE and eight other regional/international processes on criteria and indicators for sustainable forest management. The seven thematic elements had also been acknowledged by $\mathrm{FAO}(\mathrm{CICl}, 2003)$ and are used within its global Forest Resource Assessment as a reporting framework (FRA Long-Term Strategy 2012-2030 in: FAO, 2012).

\section{Seven Thematic Elements (UNFF) \\ The seven thematic elements, as adopted in the UN NLBI, Section V (ECOSOC resolution 2007/40), are the:}

1. Extent of forest resources
Four Global Objectives on Forests (UNFF) The four Global Objectives, as adopted in the UN NLBI, Section IV (ECOSOC resolution 2007/40) are to:

1. Reverse the loss of forest cover worldwide through sustainable forest management, including protection, restoration, afforestation and reforestation, and increase efforts to prevent forest degradation.

2. Forest biological diversity

3. Forest health and vitality

4. Productive functions of forest resources

5. Protective functions of forest resources

6. Socio-economic functions of forest resources

7. Legal, policy and institutional framework
3. Increase significantly the area of protected forests worldwide and other areas of sustainably managed forests, as well as the proportion of forest products derived from sustainably managed forests.

4. Reverse the decline in official development assistance for sustainable forest management and mobilize significantly increased, new and additional financial resources from all sources for the implementation of sustainable forest management. 
Annex V: Criteria of Good Practice in forest management after Winkel and Volz (2003)

\begin{tabular}{|c|c|c|c|}
\hline ID & Original & Author's translation & Original description \\
\hline 1 & Naturverjüngung & $\begin{array}{l}\text { Areas under natural } \\
\text { regeneration }\end{array}$ & $\begin{array}{l}\text { Bei der Verjüngung des Waldes ist Naturverjüngung in Abhängigkeit von betrieblichen Zielsetzungen und vorhandenen } \\
\text { Ausgangsbedingungen anderen verjüngungsverfahren vorzuziehen. Dies gilt vor allem, wenn es sich beim Altbestand um } \\
\text { einen Gentechnisch besonders erhaltenswerten Bestand handelt. }\end{array}$ \\
\hline 2 & $\begin{array}{l}\text { Sukzessionale } \\
\text { Elemente }\end{array}$ & $\begin{array}{l}\text { Elements of forest } \\
\text { successional stages }\end{array}$ & $\begin{array}{l}\text { Die Integration sukzessionaler Elemente (Vorwaldstadien, begleitende Weichlaubhölzer) in die Waldentwicklung ist ein } \\
\text { Kennzeichen Guter Fachlicher Praxis in der Forstwirtschaft. Der Aushieb von Pionierbaumarten sollte vermieden werden, } \\
\text { es sei denn, die walbaulichen Zielsetzungen des Waldeigentümers würden beeinträchtigt. }\end{array}$ \\
\hline 3 & $\begin{array}{l}\text { Natürliche } \\
\text { Sukzessions- } \\
\text { prozesse }\end{array}$ & $\begin{array}{l}\text { Non-forest areas } \\
\text { under succession to } \\
\text { forest areas }\end{array}$ & $\begin{array}{l}\text { Die Wiederbegründung von Wald kann durch natürliche Sukzessionsprozesse erfolgen, sofern diese innerhalb einer } \\
\text { absehbaren Zeitspanne zu einer Widerbewaldung der Fläche führen. }\end{array}$ \\
\hline 4 & $\begin{array}{l}\text { Befahren des } \\
\text { Waldbodens }\end{array}$ & $\begin{array}{l}\text { Driving on forest } \\
\text { soil }\end{array}$ & $\begin{array}{l}\text { Flächiges Befahren der Waldböden, darunter fällt auch eine über die Zeit changierende Befahrung, ist kein Kriterium } \\
\text { Guter Fachlicher Praxis in der Forstwirtschaft. Die Befahrung der Waldböden sollte sich auf wiederauffindbar (bzw. } \\
\text { dokumentierte) Erschließungslinien beschränken. }\end{array}$ \\
\hline 5 & $\begin{array}{l}\text { Bodenbearbei- } \\
\text { tung }\end{array}$ & Soil tilling & $\begin{array}{l}\text { Die Bearbeitung der Böden sollte sich auf ein absolut notwendiges Maß beschränken. Insbesondere sollte die natürliche } \\
\text { Struktur des Waldbodens bei der Bodenbearbeitung so wenig wie möglich beeinträchtigt werden. }\end{array}$ \\
\hline 6 & Walderschießung & $\begin{array}{l}\text { Accessibility of } \\
\text { forest areas }\end{array}$ & $\begin{array}{l}\text { Bei der Erschießung des Waldes sind im Rahmen der Guten Fachlichen Praxis das Landschaftsbild, der Waldboden und } \\
\text { der Bewuchs zu schonen sowie weitere Belange des Naturschutzes und der Landschaftspflege zu beachten. Grundsätzlich } \\
\text { sollte auf die Befestigung von Waldwegen mit Schwarzdecken verzichtet und der Bau von Wegen in sehr steilem Gelände } \\
\text { vermieden werden. }\end{array}$ \\
\hline 7 & $\begin{array}{l}\text { Mindestalter von } \\
\text { Endnutzungs- } \\
\text { beständen }\end{array}$ & $\begin{array}{l}\text { Minimum rotation } \\
\text { age }\end{array}$ & $\begin{array}{l}\text { Endnutzungen von Nadelbaumbeständen unter } 50 \text { Jahren und Laubbaumbeständen unter } 70 \text { Jahren, mit Ausnahmen von } \\
\text { Niederwaldbeständen, sonstigen Stockausschlagsbeständen, Weichholzlaubbeständen und erheblich geschädigten } \\
\text { Beständen sind nicht Kennzeichen Guter Fachlicher Praxis in der Forstwirtschaft. Dieses Kriterium gilt nicht Für } \\
\text { Endnutzungen von standortfremden Reinbeständen, die dem Umbau dieser Bestände in standortgemäße Waldbestände } \\
\text { dienen. }\end{array}$ \\
\hline 8 & $\begin{array}{l}\text { Schutz von } \\
\text { Biotopbäumen }\end{array}$ & $\begin{array}{l}\text { Protection of } \\
\text { biotope trees }\end{array}$ & $\begin{array}{l}\text { Nist- und Höhlenbäume sind in der forstwirtlichen Nutzung in Abwägung ihres naturschutzfachlichen Wertes mit } \\
\text { sonstigen forstbetrieblichen Zielsetzungen zu schonen. Insbesondere ist auf eine forstliche Nutzung von Höhlenbäumen } \\
\text { im Zeitraum zwischen den 1.3. und dem } 31.8 \text { gänzlich zu verzichten. Auf die Nutzung von Horstbäumen sowie auf die } \\
\text { Nutzung höhlenreicher Altbäume ist im Rahmen der Guten Fachlichen Praxis zu verzichten. }\end{array}$ \\
\hline 9 & Integrativer & Integrated nature & Wälder sollten auch außerhalb von ausgewiesenen Naturwaldzellen und außerhalb ausgewiesener Vorrangflächen einen \\
\hline
\end{tabular}




\begin{tabular}{|c|c|c|c|}
\hline & $\begin{array}{l}\text { Naturschutz im } \\
\text { Wirtschaftswald }\end{array}$ & $\begin{array}{l}\text { conservation in } \\
\text { commercial forest }\end{array}$ & $\begin{array}{l}\text { in Menge und Qualität ausreichenden Bestand an Alt- und Totholzanteilen aufweisen. Drüber hinaus sind Vorkommen } \\
\text { seltener Baumarten, Lichtungen, Waldwiesen und Saumbiotope zur Sicherung der Lebensräume wildlebender Tiere, } \\
\text { Pflanzen und sonstiger Organismen in ausreichendem Umfang zu erhalten. Insbesondere sind im Rahmen der Guten } \\
\text { Fachlichen Praxis Maßnahmen zu unterlassen, die zu einer erheblichen Verschlechterung des naturschutzfachlichen } \\
\text { Wertes derartiger Strukturen führen. }\end{array}$ \\
\hline 10 & Waldränder & Forest edge & $\begin{array}{l}\text { Die besondere Beachtung der ökologischen Funktionen der Waldränder ist ein Kriterium Guter fachlicher Praxis in der } \\
\text { Forstwirtschaft. Maßnahmen, die zu einer Verschlechterung dieser ökologischen Funktionen führen, sind nicht } \\
\text { Bestandteil Guter fachlicher Praxis in der Forstwirtschaft. }\end{array}$ \\
\hline 11 & $\begin{array}{l}\text { Einsatz von } \\
\text { Pestiziden, } \\
\text { Herbiziden, und } \\
\text { Holzschutzmitteln } \\
\text { im Wald }\end{array}$ & $\begin{array}{l}\text { Use of pesticides, } \\
\text { herbicides and } \\
\text { wood preservatives } \\
\text { inside forest }\end{array}$ & $\begin{array}{l}\text { Im Rahmen Guter fachlicher Praxis ist der Einsatz von chemisch-synthetischen Pestiziden, Herbiziden, und } \\
\text { Holzschutzmitteln im Wald auf ein Minimum zu beschränken. Der Einsatz von Pflanzenschutzmitteln im Bestand sollte } \\
\text { nur als letztes Mittel bei drohenden schwerwiegenden Waldschäden auf der Basis fachkundiger Begutachtung erfolgen. } \\
\text { Auf den Einsatz von Herbiziden ist grundsätzlich zu verzichten, Ausnahmen bedürfen der Genehmigung. Der Einsatz von } \\
\text { Holzschutzmitteln (Polterspritzungen) soll durch eine entsprechende Steuerung des Holzeinschlags, durch Ausnutzung } \\
\text { aller logistischen und organisatorischen Möglichkeiten weitgehend vermieden werden. }\end{array}$ \\
\hline 12 & $\begin{array}{l}\text { Schalenwild- } \\
\text { bewirtschaftung }\end{array}$ & $\begin{array}{l}\text { Hoofed game } \\
\text { management }\end{array}$ & $\begin{array}{l}\text { Angepasste Wilddichten sind eine wesentliche Voraussetzung naturnaher Forstwirtschaft. Der Forstbetrieb sollte im } \\
\text { Rahmen seiner Möglichkeiten darauf hinwirken, dass die Verjüngung der Hauptbaumarten (ökonomisch und ökologisch } \\
\text { klassifiziert) ohne Maßnahmen der Wildschadensverhütung möglich ist. Die Bejagung des Schalenwildes sollte sich an } \\
\text { diese Zielsetzung orientieren. }\end{array}$ \\
\hline 13 & $\begin{array}{l}\text { Gentechnik und } \\
\text { Forstwirtschaft }\end{array}$ & $\begin{array}{l}\text { Genetic engineering } \\
\text { in forestry }\end{array}$ & $\begin{array}{l}\text { Die Einbringung gentechnisch veränderter Organismen in den Wald ist nicht Bestandteil der Guten fachlichen Praxis in } \\
\text { der Forstwirtschaft. }\end{array}$ \\
\hline 14 & Reinbestände & Monocultures & $\begin{array}{l}\text { Das aktive Begründen von Reinbeständen mit standortwidrigen oder fremdländischen Baumarten > } 3 \text { ha Fläche ist nicht } \\
\text { Bestandteil der Guten fachlichen Praxis in der Forstwirtschaft. }\end{array}$ \\
\hline 15 & $\begin{array}{l}\text { Fremdländische } \\
\text { Baumarten }\end{array}$ & $\begin{array}{l}\text { Introduced tree } \\
\text { species }\end{array}$ & $\begin{array}{l}\text { Im Rahmen Guter fachlicher Praxis sollten auf Betriebsebene Bestände, die von fremdländischen Baumarten dominiert } \\
\text { werden einen Flächenanteil von einem Drittel nicht überschreiten. In Betrieben die aktuell mit einem höheren Anteil von } \\
\text { durch fremdländische Baumarten dominierten Beständen wirtschaften, ist der Anteil solcher Bestände im Rahmen Guter } \\
\text { Fachlicher Praxis langfristig auf einen Flächenanteil von maximal einem Drittel zurückzuführen. Ausgenommen sind } \\
\text { Betriebe mit einer Flächengröße unter } 100 \text { ha. }\end{array}$ \\
\hline 16 & $\begin{array}{l}\text { Düngung des } \\
\text { Waldes }\end{array}$ & Fertilisation & $\begin{array}{l}\text { Forstliche Düngung orientiert sich am Prinzip der Standörtlichkeit. Sie kommt daher nur zum Einsatz, um anthropogen } \\
\text { verursachenden Nährstoffmangel zu beheben und dient nicht einer Melioration der charakteristischen, standörtlich } \\
\text { natürlichen Ertragskraft. Vor dem Hintergrund der Eutrophierungsproblematik ist die Verwendung von stickstoffhaltigen } \\
\text { Düngern kein Bestandteil Guter fachlicher Praxis in der Forstwirtschaft. Ausnahmen (beispielsweise in } \\
\text { Waldschadensgebieten) bedürfen einer Genehmigung }\end{array}$ \\
\hline 17 & Kahlhiebsverbot & Clear-cutting & Kahlhiebe sind einzelstammweise oder flächige Nutzungen $>2$ ha, die den Vorrat eines Bestandes auf weniger als 40 von \\
\hline
\end{tabular}




\begin{tabular}{|l|l|l|}
\hline & & $\begin{array}{l}100 \text { des standörtlich üblichen Holzvorrates absenken. Kahlhiebe sind auch einzelstammweise oder flächige Nutzungen } \\
\text { größer als 0,5 ha wenn infolge dieser Nutzung eine erhebliche Beeinträchtigung 1. des Bodens- und der } \\
\text { Bodenfruchtbarkeit, 2. des Wasserhaushalts oder 3. sonstiger Waldfunktionen zu erwarten ist. Kahlhiebe im Sinne der } \\
\text { dieser Definition sind grundsätzlich kein Bestandteil der Guten fachlichen Praxis in der Forstwirtschaft. }\end{array}$ \\
\hline
\end{tabular}


Annex VI: Materials for Analysis of National Reporting Processes under

\section{Habitats Directive Article 17}

\section{EU Guidelines:}

EC (2000): Managing Natura 2000 sites. The provisions of Article 6 of the "Habitats" Directive 92/43/EEC. Office for Official Publications of the European Communities: Luxembourg

EC DG Env. (2004): Assessment, monitoring and reporting of conservation status -Preparing the 20012007 report under Article 17 of the Habitats Directive. DocHab-04-03/03 rev.3. Brussels.

EEA ROD (2015): Reporting Obligations Database. European Environment Information and Observation Network. http://rod.eionet.europa.eu/ (last accessed: 13.08.2015)

ETC/BD (2006): The indicative Map of European Biogeographical Regions: Methodology and development. Muséum National d'Histoire Naturelle: Paris

ETC/BD (European Topic Centre on Biological Diversity) (2011): Assessment and reporting under Article 17 of the Habitats Directive Explanatory Notes \& Guidelines for the period 2007-2012

European Commission (2011): Article 17 Reporting Reference Portal. http://bd.eionet.europa.eu/activities/Reporting/Article_17/reference_portal (accessed 27.09.2016)

EC DG Env. (2013): Interpretation Manual of European Union Habitats - EUR28. Nature ENV B.3, April 2013.

http://ec.europa.eu/environment/nature/legislation/habitatsdirective/docs/Int_Manual_EU28.pdf

Evans D and Arvela M (2011) Assessment and reporting under Article 17 of the Habitats Directive. Explanatory Notes \& Guidelines for the period 2007-2012. European Topic Centre on Biological Diversity.

Habitats Directive (1992): Council Directive 92/43/EEC of 21 May 1992 on the conservation of natural habitats and of wild fauna and flora. Official Journal L 206 , 22/07/1992 P. 0007 - 0050 http://eurlex.europa.eu/legal-content/EN/TXT/HTML/?uri=CELEX:31992L0043\&from=EN (last accessed: 06.05.2017)

Mac Sharry B (2012): User Manual for Range Tool for Article 12 (Birds Directive) \& Article 17 (Habitats Directive). EEA-European Topic Centre on Biological Diversity (ETC/BD).

http://bd.eionet.europa.eu/activities/Reporting_Tool/Documents/Range_Tool_User_Manual_1809 2012.pdf. (last accessed: 19.08.2015)

Urda D, Maxim I (2012a): Specie and Habitat types Range Tool. Gap-filling algorithm. EEA - European Topic Centre on Biological Diversity. http://bd.eionet.europa.eu/activities/Reporting/Article_17/Reporting_Tool/Reporting_Tool_Softwa re (last accessed: 19.08.2015)

Urda D, Maxim I (2012b): Specie and Habitat types Range Tool. Parameters. EEA - European Topic Centre on Biological Diversity. http://bd.eionet.europa.eu/activities/Reporting/Article_17/Reporting_Tool/Reporting_Tool_Softwa re(last accessed: 19.08.2015)

National Reports under Habitats Directive Article 17 (key documents)

BfN (2007) Report on the main results of the surveillance under article 11 for Annex I habitat types (Annex D). http://cdr.eionet.europa.eu/de/eu/art17/envrOqzdw/index_html?\&page=4

BfN (2013a): Report on the main results of the surveillance under article 11 for Annex I habitat types (Annex D). http://cdr.eionet.europa.eu/de/eu/art17/envunipoa/index_html?\&page=4

BfN (2013b): Range and Distribution maps. Report 2013. maps http://www.bfn.de/0316_natbericht_2013-komplett.html

Swedish Environment Protection Agency (naturvardsverket), 2013. Report on the main results of the surveillance under article 11 for Annex I habitat types (Annex D) http://cdr.eionet.europa.eu/Converters/run_conversion?file=se/eu/art17/envucgywg/SE_habitats reports-131223-141035.xml\&conv=350\&source=remote\#9010 
Adler S (2014) Combing survey data. Oral presentation. Final conference LIFE+ MOTH. 11-12 November 2014. Carion Hotel Gillet, Uppsala

Angelstam P and Andersson L (2001): Estimates of the Needs for forest reserves in Sweden. Scandinavian Journal of Forest Research, 16:S3, http://dx.doi.org/10.1080/028275801300090582 Anonymous (2015): Interview with reporting authority. mail contact.

Ahlkrona E, Engdal A, Ledwith M, Olsson B, Sehlsted Å (2010): Utbredningskartor för Natura 2000 naturtyper. Rapport för Naturvårdsverket. Metria: Stockholm (translated)

Bayrische Staatsregierung (2016): Bayern Atlas. Information on data from biotope mapping programes. http://geoportal.bayern.de/bayernatlas/?X=5421649.25\&Y=4459462.00\&zoom=5\&lang=de\&topic= umwe\&bgLayer=atkis\&catalogNodes=1102 (last acessed, 29.10.2016)

BfN (2013): Nationaler Biotopverbund: Datengrundlage und Methoden. https://www.bfn.de/0311_nat_biotopverbund.html (last accessed 07.12.2016)

BMEL, TI (2014): Survey instructions for the 3rd National Forest Inventory (2011-2012) 2nd revised version, Mai 2011 with 4. Corrigendum (21.03.2014). BMEL: Bonn

Burkhardt R, Robisch F and Eckhard S unter Mitarbeit der Mitglieder der LANA-FCK-Kontaktgruppe und des Bund-Länder Arbeitskreises „FFH-Berichtspflichten: Wald“ (2004): Umsetzung der FFH-Richtlinie im Wald. Gemeinsame bundesweite Empfehlungen der Länderarbeitsgemeinschaft Naturschutz (LANA) und der Forstchefkonferenz (FCK). Natur und Landschaft 2004/7: 316-323

Eide W et al. (2014): Arter och naturtyper i habitatdirektivet - bevarandestatus i Sverige 2013. ArtDatabanken SLU, Uppsala. (translated)

Forsman H, Hagner Å, Gardfjell H, Adler S (n.d.): Habitat Inventory by Aerial Photo Interpretation in MOTH - Terrestrial and Seashore Inventory. Department of Forest Resource Management, SLU: Umeå, Sweden.

Fridman J, Holm S, Nilsson M, Nilsson P, Ringvall AH, Ståhl G (2014). Adapting National Forest Inventories to changing requirements - the case of the Swedish National Forest Inventory at the turn of the 20th century. Silva Fennica 48 (3): 1 - 29. http://www.silvafennica.fi/pdf/article1095.pdf (last accessed: 06.05.2017)

Gardfjell H, Hellbery E, Abenius J (2007): Using existing landscape monitoring programmes for monitoring and reporting on the Habitats Directive. Manuscript presented at PEER Nature2000 workshop: Concepts, Methods and Tools for Conservation Status Assessment, Reporting and Monitoring. in Roskilde (DK): 25-27 April 2007.

Gardfjell, Hans and Hagner, Åsa (2014): Instruction for Inventory of Habitats in NILS and MOTH, 2014. SLU Department of Forest Resource Management, Umeå.

Gardfjell (2014): MOTH more and better knowledge of less common habitats - a LIFE+ project. Layman report (LIFE3VNAT/S/333+X7). SLU: Umeå, Sweden.

Kroiher (2013): Methode zur Erfassung und Bewertung der FFH-Waldlebensraumtypen im Rahmen der dritten Bundeswaldinventur (BWI-2012). unpublished report.

LANA (2001): Beschlüsse der Arbeitsgemeinschaft "Naturschutz" der Landesumweltministerien (LANA). 81th session. Pinneberg: September 2001. https://www.bfn.de/fileadmin/MDB/documents/030306_lana.pdf

Landmäteriet (2017): Digital Aerial Imagery. https://www.lantmateriet.se/en/Maps-and-geographicinformation/Aerial-and-satellite-images-/Aerial-Photography/Digitala-flygbilder/ (last accessed: 05.05.2017)

Lang S (2012): MS.Monina. Multi-Scale Service for Monitoring Natura 2000 habitats of European Community Interest. Deliverable 2.1.

LWF (2007): Anweisung für die FFH-Inventur. Anleitung zum praktischen Vorgehen (in Ergänzung zur Arbeitsanweisung). Version 1.2.

Müller-Kroehling S (2016): FFH-Managementpläne im Wald. Schlüssigkeit der Landesverfahren wichtiger als bundesweite Einheitlichkeit . Naturschutz und Landschaftsplanung 43(6): 190-191.

Ranneby B, Crusee T, Hägglund B, Jonasson H, Sward J (1987): Designing a new national forest survey for Sweden. Studia Forstalia Suecica No. 177: Uppsala.

Rosenkranz L, Wippel B, Seintsch B (2012): FFH-Impact: Teil 1: Umsetung der FFH-Richtlinie im Wald in 
den Bundesländern. Work Report. vTI: Bonn

Sachteleben J, Behrens M (2010a): Konzept zum Monitoring des Erhaltungszustandes von Lebensraumtypen und Arten der FFH-Richtlinie in Deutschland. BfN-Skripten 278. BMU-Druckerei: Bonn, Bad Godesberg

Sachteleben J, Fartmnann T, Neukirchen M, Weddeling K (2010b): Bewertung des Erhaltungszustandes der Lebensraumtypen nach Anhang I der Fauna-Flora-Habitat-Richtlinie in Deutschland Überarbeitete Bewertungsbögen der Bund-Länder-Arbeitkreise als Grundlage für ein bundesweites FFH-Monitoring. Im Auftrag des Bundesamtes für Naturschutz - FKZ 80582 013. PAN/ILÖK: München

Schmidt et al. (2006): Erfassung von Wald-Lebensraumtypen in FFH-Gebieten. Fernerkundung am Taubenberg und im Angelberger Forst. LWF Wissen 51: pp.39

SLU (2015a): Markinventeringen - Swedish Forest Soil Inventory. http://www.slu.se/en/collaborativecentres-and-projects/swedish-forest-soil-inventory/(last accessed: 19.08.2015)

SLU (2015b):MOTH, more and better knowledge of less common habitats - a LIFE+ project. Layman's report. https://www.slu.se/en/Collaborative-Centres-and-Projects/moth/publications/(last accessed: 19.08.2015)

Ståhl G, Allard A, Esseen PA, Glimskär A, Ringvall A, Svensson J, Sundquist S, Christensen P, Gallegos Torell $\AA$, Högström M, Lagerqvist K, Marklund L, Nilsson B and Inghe $O$ (2011): National Inventory of Landscapes in Sweden (NILS) - Scope, design, and experiences from establishing a multiscale biodiversity monitoring system. Environ. Monit. Assess 173: 379-595.

TI (2014): Dritte Bundeswaldinventur 2012. Ergebnisdatenbank. https://bwi.info/start.aspx (last acessed: 2014) 
Annex VII: German data requirements when reporting under Habitats Directive.

The table summarises European requirements by attributes to be reported to the European commission. It also shows the 8 quality characteristics deemed relevant by German reporting authorities. Numeric figures show how many of the 33 reports satisfied the individual data quality requirements and links them to the providing authorities. The overrepresentation of the Bavarian programme is corrected by figures in brackets, these exclude the 18 Bavarian assessments and include only assessments of other federal states. Empty cells show cases where I could neither confirm nor reject relevance of a data quality criterion.

\begin{tabular}{|c|c|c|c|c|c|c|c|c|c|c|c|}
\hline \multirow{2}{*}{$\frac{n}{\frac{\pi}{2}}$} & Stakeholder group & \multicolumn{5}{|l|}{ Environment } & \multirow{2}{*}{$\begin{array}{l}\text { Forestry } \\
\mathrm{TI}^{3} \text { and } \mathrm{LWF}^{4}\end{array}$} & \multirow{2}{*}{\multicolumn{4}{|c|}{$\begin{array}{l}\text { Both Environment and Forestry } \\
\text { Bund-Länder Conferences (decision of committee) }\end{array}$}} \\
\hline & Consulted authorities & \multicolumn{2}{|l|}{ Länder ${ }^{1}$} & \multicolumn{3}{|l|}{$\mathrm{BfN}^{2}$} & & & & & \\
\hline \multirow{2}{*}{ 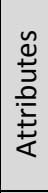 } & \multirow[t]{2}{*}{$\begin{array}{l}\text { Report criteria and values to be filled out in the } \\
\text { report }\end{array}$} & \multicolumn{2}{|l|}{ Habitat area } & \multicolumn{2}{|l|}{ Range } & \multicolumn{3}{|c|}{ Specific structures and functions } & \multirow{2}{*}{\begin{tabular}{|l|} 
Habitat area \\
Overall \\
status \\
(index) \\
\end{tabular}} & \multirow{2}{*}{\begin{tabular}{|l|} 
Range \\
Overall \\
status \\
(index) \\
\end{tabular}} & \multirow{2}{*}{\begin{tabular}{|l|} 
Future \\
Prospects \\
Overall \\
status \\
(index) \\
\end{tabular}} \\
\hline & & $\begin{array}{l}\text { Cover } \\
\left(\mathrm{km}^{2}\right)\end{array}$ & $\begin{array}{l}\text { Trends } \\
(+, 0,-)\end{array}$ & $\begin{array}{l}\text { Cover } \\
\left(\mathrm{km}^{2}\right)\end{array}$ & $\begin{array}{l}\text { Trends } \\
(+, 0,-)\end{array}$ & $\begin{array}{l}\text { Overall } \\
\text { status } \\
\text { (index) }\end{array}$ & $\begin{array}{l}\text { Overall } \\
\text { status } \\
\text { (index) }\end{array}$ & $\begin{array}{l}\text { Overall } \\
\text { status } \\
\text { (index) }\end{array}$ & & & \\
\hline \multirow{8}{*}{ 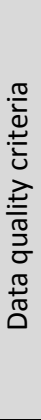 } & 1. National harmonisation of methods & 0 & 0 & 33 & 33 & 13 & 18 & - & - & - & - \\
\hline & 2. Compromise on methods & - & - & - & - & 13 & 18 & - & - & - & 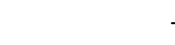 \\
\hline & 3. Sample size & - & - & - & - & 13 & 18 & - & - & - & . \\
\hline & 4. Statistical measures of precision and accuracy & $18(0)$ & $18(0)$ & $18(0)$ & $18(0)$ & 0 & 18 & 0 & 0 & 0 & 0 \\
\hline & 5. Transparency of methods & $18(0)$ & $18(0)$ & $18(0)$ & $18(0)$ & 0 & 18 & 0 & 0 & 0 & 0 \\
\hline & 6. Cause-effects & - & - & - & - & 15 & 0 & - & - & - & - \\
\hline & 7. Assessment of rare events & 33 & 33 & 33 & 33 & 0 & 0 & - & - & - & 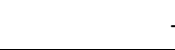 \\
\hline & 8. No public involvement & - & - & - & - & - & - & 33 & 33 & 33 & 33 \\
\hline \multicolumn{2}{|c|}{ Total number of values } & $33(15)$ & $33(15)$ & 33 (15) & $33(15)$ & 15 & 18 & 33 & 33 & 33 & 33 \\
\hline
\end{tabular}

Conserion agencies of the federal states of Germany

for Nature Conservation

$3=$ Thunen Institute/ Federal Research Institute for Rural Areas, Forestry and Fisheries

${ }^{4}=$ State Agency of Bavaria for Forestry and Silviculture 


\section{Annex VIII: Swedish data requirements when reporting under Habitats}

\section{Directive.}

The table summarizes European requirements by attributes to be reported to the European commission. It also shows the 7 quality characteristics deemed relevant by Swedish reporting authorities. Numeric figures show how many of the 35 reported values satisfied the individual data quality requirements and links them to the providing authorities. Empty cells show cases where I could neither confirm nor reject relevance of a data quality criterion.

\begin{tabular}{|c|c|c|c|c|c|c|c|c|c|}
\hline \multirow{2}{*}{$\begin{array}{l}\frac{n}{2} \\
\frac{0}{2} \\
\frac{0}{2}\end{array}$} & Stakeholder group & \multicolumn{8}{|c|}{ Both Environment and Forestry } \\
\hline & Consulted authorities & \multicolumn{8}{|l|}{$S_{L} U^{1}$} \\
\hline \multirow{2}{*}{ 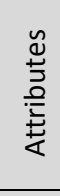 } & \multirow[t]{2}{*}{$\begin{array}{l}\text { Variables and values to be filled out in the } \\
\text { report }\end{array}$} & \multicolumn{2}{|c|}{ Habitat area } & \multirow{2}{*}{\begin{tabular}{|l|} 
Range \\
$\begin{array}{l}\text { Cover } \\
\left(\mathrm{km}^{2}\right)\end{array}$ \\
\end{tabular}} & \multirow[b]{2}{*}{$\begin{array}{l}\text { Trends } \\
(+, 0,-)\end{array}$} & Habita & Range & $S \& F^{3}$ & $\begin{array}{l}\text { Future } \\
\text { Pro- }\end{array}$ \\
\hline & & $\begin{array}{l}\text { Cover } \\
\left(\mathrm{km}^{2}\right)\end{array}$ & $\begin{array}{c}\text { Trends } \\
(+, 0,-)\end{array}$ & & & \multicolumn{4}{|c|}{ Overall status (index) } \\
\hline \multirow{9}{*}{ 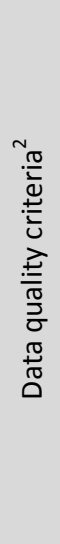 } & \multicolumn{9}{|l|}{ Measurement methods } \\
\hline & 1. Remote sensing at $0.5 \mathrm{~m}$ resolution & 35 & 0 & 35 & 0 & 35 & 35 & - & . \\
\hline & 2. Ground-based measurements & 35 & 0 & 35 & 0 & 35 & 35 & - & \\
\hline & \multicolumn{9}{|l|}{ Statistical and analytic qualities } \\
\hline & $\begin{array}{l}\text { 3. Sampling grid at least } 5 \times 5 \mathrm{~km} \text { (ground- } \\
\text { based measurements) }\end{array}$ & 35 & - & 35 & - & 35 & 35 & - & 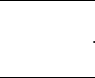 \\
\hline & $\begin{array}{l}\text { 4. Sampling grid at least } 2.5 \times 5 \mathrm{~km} \\
\text { (remote sensing) }\end{array}$ & 35 & . & 35 & & 35 & 35 & - & . \\
\hline & 5. Sample size (at least 30 ) & 35 & - & 35 & - & - & - & - & \\
\hline & $\begin{array}{l}\text { 6. Statistical measures of precision and } \\
\text { accuracy }{ }^{4}\end{array}$ & 35 & 0 & 35 & 0 & 0 & 0 & 0 & 0 \\
\hline & 7. Transparency of methods & 0 & 0 & 0 & 0 & 0 & 0 & 0 & 0 \\
\hline \multicolumn{2}{|c|}{ Total number of reports } & 35 & 35 & 35 & 35 & 35 & 35 & 35 & 35 \\
\hline
\end{tabular}




\section{Literature}

Adler S (2014): Combing survey data. Oral presentation. Final conference LIFE+ MOTH. 1112 November 2014. Carion Hotel Gillet, Uppsala.

Ahlkrona E, Engdal A, Ledwith M, Olsson B, Sehlsted Å (2010): Utbredningskartor för Natura 2000 naturtyper. Rapport för Naturvårdsverket. Metria: Stockholm.

AHTEG - Ad Hoc Technical Expert Group (2011): Streamlining European Biodiversity

Indicators - Lessons Learned from a regional process. UNEP/CBD/AHTEG-SP-

Ind/1/INF/7. Ad Hoc Technical Expert Group Meeting on Indicators for the Strategic Plan for Biodiversity 2011-2020. High Wycombe, United Kingdom, 20-24 June 2011.

Aldinger E and Müller-Kroehling S (2012): Diskussionsbeitrag- Naturschutz und

Landschaftsplanung 44(2), 59-60.

Angelstam P and Andersson L (2001): Estimates of the Needs for forest reserves in Sweden.

Scandinavian Journal of Forest Research 16 (3)

http://dx.doi.org/10.1080/028275801300090582.

Angelstam P, Mikusiński G, Fridman J (2004): Natural forest remnants and transport

infrastructure - does history matter for biodiversity conservation planning? Ecological

Bulletins 51, 149-162.

Anonymous (2016): Strategy of ICP Forests 2016-2023,p. 4. http://www.icp-

forests.org/Manual.htm.

Araujo MB, Guisan A (2006): Five (or so) challenges for species distribution modelling.

Journal of Biogeography 33, 1677-1688.

Armstrong JS, Overton TS (1977): Estimating nonresponse bias in mail surveys. Journal of

Marketing Research 14 (3), Special Issue: Recent Developments in Survey Research, $396-402$.

Arnold FE, Rametsteiner E, Kleinn C (2014a): User-Oriented National Forest Monitoring

Planning: A Contribution to More Policy Relevant Forest Information Provision.

International Forestry Review 16(4),389-404.

Arnold FE, van der Werf N, Rametsteiner E (2014b): Strengthening evidence-based forest policy-making. Linking forest monitoring with national forest programmes. Forest Policy and Institutions Working Paper 33, FAO: Rome, pp. 24.

Ascough II JC, Maier HR, Ravalico JK, Strudley MW (2008): Future research challenges for incorporation of uncertainty in environmental and ecological decision-making. Ecological Modelling 219, pp. 383-399. 
Axelrod R (1976): Structure of Decision. The Cognitive Maps of Political Elites. University of Princeton Press, Princeton.

Bai ZG, Dent DL, Olsson L, Schaepman ME (2008): Proxy global assessment of land degradation. Soil Use and Management 24, 223-234.

Balmford et al. (2002): Economic Reasons for Conserving Wild Nature. Science 297, 950953.

Barry D, Oelschlaeger M (1996): A science for Survival: Values and Conservation Biology. Conservation Biology 10 (3), 905-911.

Battersby JE, Greenwood JJD (2004): Monitoring terrestrial mammals in the UK: past, present and future, using lessons from the bird world, Mammal Review 34, pp. 3-29.

Bayrische Staatsregierung (2016): Bayern Atlas. Information on data from biotope mapping programmes.

http://geoportal.bayern.de/bayernatlas/?X=5421649.25\&Y=4459462.00\&zoom=5\&lang= de\&topic=umwe \&bgLayer=atkis\&catalogNodes=1102 (last accessed: 29.10.2016).

Bell KL, de Vere N, Keller A, Richardson RT, Gous A, Burgess KS, Brosi BJ (2016): Pollen DNA barcoding: current applications and future prospects. Genome 59 (9), 629-640.

BfN (2007) Report on the main results of the surveillance under article 11 for Annex I habitat types (Annex D).

http://cdr.eionet.europa.eu/de/eu/art17/envr0qzdw/index_html? \&page=4 (last accessed: 29.10.2016).

BfN (2013): Nationaler Biotopverbund: Datengrundlage und Methoden. https://www.bfn.de/0311_nat_biotopverbund.html (last accessed: 07.12.2016).

BfN (2013a): Report on the main results of the surveillance under article 11 for Annex I habitat types (Annex D).

http://cdr.eionet.europa.eu/de/eu/art17/envunipoa/index_html? \&page=4 (last accessed: 29.10.2016).

BfN (2013b): Range and Distribution maps. Report 2013. maps http://www.bfn.de/0316_natbericht_2013-komplett.html (last accessed: 29.10.2016).

Bielefeldt J, Bolte A, Busch G, Dohrenbusch A, Kroiher F, Lamersdorf N, Schulz U, Stoll B (2008): Energieholzproduktion in der Landwirtschaft: Chancen und Risiken aus Sicht des Natur- und Umweltschutzes. NABU: Berlin.

BISE (2016): Biodiversity Information System for Europe. online-database on biodiversity supporting the implementation of the EU strategy and the Aichi targets in Europe. http://biodiversity.europa.eu (last accessed: 07.02.2017). 
BMEL (1986): Bundeswaldinventur Instruktion für die Tracktaufnahme. BMEL: Bonn, pp. 341

BMEL (2008): Waldstrategie 2020. Nachhaltige Waldbewirtschaftung - eine gesellschaftliche Chance und Herausforderung. Bonn.

BMEL, TI (2014): Survey instructions for the 3rd National Forest Inventory (2011-2012) 2nd revised version, Mai 2011 with 4. Corrigendum (21.03.2014). BMEL: Bonn.

BMELV (2000): Aufnahmeanweisung für die Bundeswaldinventur II [Data Collection Guideline for the 2nd German Inventory]. BMELV: Bonn, $114 \mathrm{pp}$. http://www.bundeswaldinventur.de/media/archive/214.pdf. (last accessed: 21.02. 2014)

BMELV (2009): Waldbericht der Bundesregierung 2009. Publikationsversand der Bundesregierung: Rostock.

BMELV (2014): Survey instructions for the 3rd National Forest Inventory (2011-2012), 2nd revised version, May 2011 with 4. Corrigendum (21.03.2014). BMELV: Bonn.

BMU (2007): National Strategy on Biological Diversity. Adopted by the Federal Cabinet on 7 November 2007. http://biologischevielfalt.bfn.de/ (last accessed: 12.06.2017).

BMUB (2016): Integriertes Umweltprogramm 2030. Den ökologischen Wandel gestalten.BMUB: Berlin.

BMUB (2018): Ressortforschung des Bundesministeriums für Umwelt, Naturschutz, Bau und Reaktorsicherheit. Forschungsrahmen und Ressortforschungsplan 2018. available online: http://www.bmub.bund.de/themen/forschung-foerderung/forschung/ressortforschungforschungsrahmen (last accessed: 24.02.2018).

Böcher M, Krott M (2010): Umsetzung des Konzepts einer modernen Ressortforschung im Geschäftsbereich des BMU. Umweltbundesamt: Dessau-Roßlau. http://www.uba.de/ubainfo-medien/3995.html (last accessed: 29.12.2017).

Buck O (2012): DeCOVER 2. Aufbau von Fernerkundungsdiensten zur Aktualisierung der Landbedeckung. Deutschen Gesellschaft für Photogrammetrie, Fernerkundung und Geoinformation (21), pp. 487.

Buck O, Hinterlang D, Müterthies A, Rühl J (Hrsg.) (2014): Einsatz von FernerkundungsDaten im Rahmen von FFH -Monitoring-Diensten in Deutschland: get ready for SENTINEL @ All. Tagungsdokumentation des Workshops vom 31.03. bis 01.04.2014 im Bundesamt für Naturschutz, Bonn. BfN-Skripten 388. BMU-Druckerei: Bonn, Bad Godesberg. https://www.bfn.de/0502_skripten.html (last accessed: 26.22.2015) 
Buckland ST, Anderson DR, Burnham KP, Laake JL, Borchers DL., Thomas L (2001): Introduction to distance sampling: estimating abundance of biological populations. Oxford University Press, Oxford. 432 p.

Buckland ST, Russell RE, Dickson BG, Saab VA, Gorman DG, Block WM (2009): Analysing designed experiments in distance sampling. Journal of Agricultural, Biological and Environmental Statistics 14 (4), 432-442. https://doi.org/10.1198/jabes.2009.08030 (last accessed: 15.04.2018)

Buckland ST, Russell RE, Dickson BG, Saab VA, Gorman DG, Block WM (2009): Analysing designed experiments in distance sampling. Journal of Agricultural, Biological and Environmental Statistics 14 (4), 432-442.

Burkhardt R, Robisch F, Eckhard S with contributions of members of LANA-FCKKontaktgruppe and of Bund-Länder Arbeitskreises „FFH-Berichtspflichten: Wald“ (2004): Umsetzung der FFH-Richtlinie im Wald. Gemeinsame bundesweite Empfehlungen der Länderarbeitsgemeinschaft Naturschutz (LANA) und der Forstchefkonferenz (FCK). Natur und Landschaft 7, 316-323.

Cantarello E, Newton AC (2008): Identifying cost-effective indicators to assess the conservation status of forested habitats in Natura 2000 sites. Forest Ecology and Management 256, 815-826.

CDU, CSU und SPD (2018): Ein neuer Aufbruch für Europa Eine neue Dynamik für Deutschland Ein neuer Zusammenhalt für unser Land. Koalitionsvertrag zwischen CDU, CSU und SPD. Berlin: 7. Februar 2018

Chaytor B (2001): The development of global forest policy - overview of legal and institutional frameworks. International Institute for Environment and Development/ World Business Council for Sustainable Development: Geneva.

Convention on Biological Diversity (CBD) (1992): Convention on biological diversity. Text of treaty. Ch_XXVII_8. Rio de Janeiro, 05.06.1992

Convention on Biological Diversity (CBD) (1997): Recommendations for a core set of indicators of biological diversity. UNEP/CBD/SBSTTA/3/Inf.13. Montreal, Canada, CBD Secretariat.

COP of the CBD (2012): Decision XI/3. Monitoring progress in implementation of the Strategic Plan for Biodiversity 2011-2020 and the Aichi Biodiversity Targets. CBD-COP: Hyderabad, India. https://www.cbd.int/decision/cop/default.shtml?id=13164 (last accessed: 15.04.2018). 
COP of the Kyoto Protocol (2005): FCCC/KP/CMP/2005/8/Add.2.

http://unfccc.int/documentation/decisions/items/3597.php?id=3597\#beg (last accessed: 09.06.2017).

Costanza R, d'Arge R, de Groot RS, Farber S, Grasso M, Hannon B, Limburg K, Naeem S, O’Neill RV, Paruelo J, Raskin RG, Sutton P, van den Belt M, (1997): The value of the world's ecosystem services and natural capital. Nature 387 (15), 253-260.

Curran T, Doyle, J (2011): Picture Superiority Doubly Dissociates the ERP Correlates of Recollection and Familiarity. Journal of Cognitive Neuroscience 23 (5), 1247-1268.

Defeyter MA, Russo R, McPartlin PL (2009): The picture superiority effect in recognition memory: A developmental study using the response signal procedure. Cognitive Development 24 (3), 223-338.

de Groot R, Wilson MA, Boumans RMJ (2002): A typology for the classification, description and valuation of ecosystem functions, goods and services. Ecological Economics 41, 392408.

de Sy N (2012): Forest monitoring should integrate biodiversity and socioeconomic data, say experts. http://blog.cifor.org/13018/forest-monitoring-should-integrate-biodiversity-andsocioeconomic-data-say-experts?fnl=en (last accessed 29.03.2017).

Dejean T, Valentini A, Duparc A, Pellier-Cuit S, Pompanon F, Taberlet P, et al. (2011): Persistence of Environmental DNA in Freshwater Ecosystems. PLoS ONE 6 (8): e23398. https://doi.org/10.1371/journal.pone.0023398 (last accessed: 15.04.2018).

Der Bundeswahlleiter (2015): Ergebnisse früherer Bundestagswahlen. Wiesbaden.

CICI (2003): REPORT International Conference on the Contribution of Criteria and Indicators for Sustainable Forest Management: The Way Forward (CICI-2003).Volume 2. 3 - 7 February 2003, Guatemala City, Guatemala http://www.fao.org/docrep/005/J0077E/J0077E00.HTM (last accessed 04.06.2017)

Dietz T (2003): What is a Good Decision? Criteria for Environmental Decision Making. Human Ecology Review 10 (1), 33-39.

Dimitrov RS (2005): Hostage to norms: states, institutions and global forest politics. Global Environmental Politics 5 (4), 1-24.

Dimitrov RS, Sprinz DF, Diguisto GM, Kelle A (2007): International Nonregimes: A Research Agenda. International Studies Review 9, 230-258.

Dröschmeister R (2001): Bundesweites Naturschutzmonitoring in der " Normallandschaft", mit der Ökologischen Flächenstichprobe. Nat. Landschaft 76 (2), 58-69. 
Dunz T (2005): Übergang der Monitoringpflicht von Mitgliedstaat zum Vorhabenträger - Die Sicht der Vorhabenträger. In: Haak A, Kurz H, Brandt I (2005): Die Monitoringpflicht für europäische Schutzgebiete des Netzes NATURA 2000. VSÖ-Publikationen 6. ad fontes verlag: Hamburg.

DVL (Deutscher Verband für Landschaftspflege e.V.) (2008): Wege zur Finanzierung von Natura 2000. Gute Beispiele, wie Europa die biologische Vielfalt voranbringt. Landschaft als Lebensraum 15.

EC (2000): Managing Natura 2000 sites. The provisions of Article 6 of the "Habitats" Directive 92/43/EEC. Office for Official Publications of the European Communities: Luxembourg.

EC (2007): Managing the Agriculture Budget Wisely. Luxembourg: Office for Official Publications of the European Communities http://ec.europa.eu/agriculture/publi/fact/clear/2007_en.pdf (last accessed: 15.04.2018). EC (2014a): On-the-spot checks according to art, 24, 25, 26, 27, 30, 31, 34, 35, 36, 37,38,39,40, 41 of Regulation (EU) 809/2014. Guidance for on-the-spot checks (OTSC) and area measurement. DSCG/2014/32-Final. European Commission Directorate General for Agriculture and Rural Development.

EC (2014b): Fifth report of the European Union to the Convention on Biological Diversity. pp. 54.

EC DG Env. (2004): Assessment, monitoring and reporting of conservation status -Preparing the 2001-2007 report under Article 17 of the Habitats Directive. DocHab-04-03/03 rev.3.

EC DG Env. (2013): Interpretation Manual of European Union Habitats - EUR28. Nature ENV B.3, April 2013.

http://ec.europa.eu/environment/nature/legislation/habitatsdirective/docs/Int_Manual_EU 28.pdf (last accessed 27.09.2016).

EEA (2007): Halting the loss of biodiversity by 2010: proposal for a first set of indicators to monitor progress in Europe. EEA Technical report 11. Office for Official Publications of the European Communities: Luxembourg, pp. 182.

EEA (2014): Digest of EEA indicators 2014. Technical Report 8. https://www.eea.europa.eu/publications/digest-of-eea-indicators-2014/file (last accessed: 15.04.2018).

EEA (2015): European ecosystem assessment: Concept, data, and implementation. EEA Technical Report No 6/2015 http://www.eea.europa.eu/publications/europeanecosystemassessment (last accessed: 03.02.2018). 
EEA ROD (2015): Reporting Obligations Database. European Environment Information and Observation Network: Brussels. http://rod.eionet.europa.eu/ (last accessed: 13.08.2015) Ehrlich P, Ehrlich A (1981): Extinction: The causes and consequences of the disappearance of species. New York: Random House.

Eide W. (Ed.) (2014): Arter och naturtyper i habitatdirektivet - bevarandestatus i Sverige 2013. ArtDatabanken SLU: Uppsala.

Epstein Y, López-Bao JV, Chapron G (2015): A Legal-Ecological Understanding of Favorable Conservation Status for Species in Europe. Conservation Letters, 1-8. ETC/BD (2006): The indicative Map of European Biogeographical Regions: Methodology and development. Muséum National d'Histoire Naturelle: Paris.

ETC/BD (2011): Assessment and reporting under Article 17 of the Habitats Directive Explanatory Notes \& Guidelines for the period 2007-2012.

European Commission (2011): Article 17 Reporting Reference Portal.

http://bd.eionet.europa.eu/activities/Reporting/Article_17/reference_portal (last accessed 27.09.2016).

European Commission (2014): Mapping and Assessment of Ecosystem Services. Indicators for ecosystem assessments under Action 5 of the EU Biodiversity Strategy 2020. 2nd MAES Working Paper. Technical Report 2014-080.pp. 80.

http://ec.europa.eu/environment/nature/knowledge/ecosystem_assessment/pdf/2ndMAES WorkingPaper.pdf (last accessed 22.04.2018).

European Council (2011): EU Biodiversity Strategy to 2020: towards implementation -

Council conclusions. European Council Conclusion 18862/11 EE/cm 1DG I 1A. http://register.consilium.europa.eu/doc/srv?l=EN\&f=ST\%2018862\%202011\%20INIT (last accessed 22.04.2018).

European Forest Institute (2013): Implementing Criteria and Indicators for Sustainable Forest Management in Europe. http://www.efi.int/files/attachments/publications/efi_ci_report_implementing_criteria_net_final.pdf (last accessed: 15.04.2018).

Evans D (2012): Building the European Union's Natura 2000 network. Nature Conservation 1: 11-26.

Evans D, Arvela M (2011) Assessment and reporting under Article 17 of the Habitats Directive. Explanatory Notes \& Guidelines for the period 2007-2012. European Topic Centre on Biological Diversity.

Evans D (2018): Personal communication. by email 13.03.2018-04.04.2018. 
Failing L, Gregory R (2003): Ten common mistakes in designing biodiversity indicators for forest policy. Journal of Environmental Management 68, 121-132.

FAO (2012):Supporting Sustainable Forest Management Through The Global Forest Resources Assessment: Long-Term Strategy (2012-2030). http://www.fao.org/forestresources-assessment/en/ (last accessed on 04.06.2017)

FAO (2013): Resilient livelihoods - disaster risk reduction for food and nutrition security. FAO: Rome.

FAO (2014a): State of the World's Forests. Enhancing the socioeconomic benefits from forests. FAO: Rome.

FAO (2014b): Contribution of the forestry sector to national economies, 1990-2011, by A.

Lebedys and Y. Li. Forest Finance Working Paper FSFM/ACC/09. FAO: Rome.

FAO (2014c): The State of the World's Forest Genetic Resources. FAO: Rome. pp.276

FAO (2016): Global Forest Resources Assessment 2015. How are the world's forests changing? 2nd ed. FAO: Rome.

FAO (2017): Living in and from the forests of Central Africa. FAO: Rome.

Faugier J, Sargeant M (1997) Sampling hard to reach populations, Journal of Advanced Nursing 26, 790-797.

Fink P, Heinze S, Raths U, Rieken U, Ssymank A (2017): Rote Liste der gefährdeten Biotoptypen Deutschlands. dritte fortgeschriebene Fassung 2017. Naturschutz und Biologische Vielfalt 156. 637 p.

Forest Europe (2015): State of Europe's Forests 2015. Ministerial Conference on the Protection of Forests in Europe Liaison Unit: Madrid.

Forsman H, Hagner ^̊, Gardfjell H, Adler S (n.d.): Habitat Inventory by Aerial Photo Interpretation in MOTH - Terrestrial and Seashore Inventory. Department of Forest Resource Management, SLU: Umeå, Sweden.

Freeman SN, Noble DG, Newson SE, Baillie SR(2007): Modelling population changes using data from different surveys: the Common Birds Census and the Breeding Bird Survey. Bird Study 54 (1), 61-72.

Fridman J, Holm S, Nilsson M, Nilsson P, Ringvall AH, Ståhl G (2014): Adapting National Forest Inventories to changing requirements - the case of the Swedish National Forest Inventory at the turn of the 20th century. Silva Fennica 48 (3), 1 - 29. http://www.silvafennica.fi/pdf/article1095.pdf (last accessed: 06.05.2017)

Froehlich-Schmitt B (2011): Schlappe für Naturschutz im Wald? FFH-Monitoring der WaldLebensraumtypen unter Forst-Kuratel. Naturschutz und Landschaftsplanung 43, 379-384. 
Gardfjell H (2014): MOTH more and better knowledge of less common habitats - a LIFE+ project. Layman report (LIFE3VNAT/S/333+X7), SLU: Umeå, Sweden.

Gardfjell H, Hagner Å (2014): Instruction for Inventory of Habitats in NILS and MOTH, 2014. SLU Department of Forest Resource Management: Umeå.

Gardfjell H, Hellbery E, Abenius J (2007): Using existing landscape monitoring programmes for monitoring and reporting on the Habitats Directive. Manuscript presented at PEER Nature2000 workshop: Concepts, Methods and Tools for Conservation Status Assessment, Reporting and Monitoring. in Roskilde (DK), 25-27 April 2007.

Giessen L (2013): Reviewing the main characteristics of the international forest regime complex and partial explanations for its fragmentation. International Forestry Review 15 (1), 60-70.

Giessen L, Krott M, Möllmann T (2014): Increasing representation of states by utilitarian as compared to environmental bureaucracies in international forest and forest-environmental policy negotiations. Forest Policy and Economics 38, 97-104.

Gilbert AJ, Janssen R (1997): The use of environmental functions to evaluate management strategies for the Pagbilao Mangrove Forest. CREED Working Paper No. 15.

Gill P, Stewart K, Treasure E, Chadwick B (2008): Methods of data collection in qualitative research: interviews and focus groups. British Dental Journal 204(6), 291-295.

Gjertsen AK (2007): Accurarcy of forest mapping based on Landsat TM data and a kNNbased method. Remote Sensing of Environment 110, 420-430.

Greene T, Jones A, Dennis G, Sachtleben T (2010): Distance sampling to determine kaka (Nestor meridionalis septentrionalis) density within Waipapa Ecological Area, Pureora. New Zealand Journal of Ecology 34(3), 297-305.

Greene TC, Efford E (2012): Birds: estimates of absolute density and abundance - distance sampling. Supporting material for the Inventory and Monitoring Toolbox. Version 1.0. Department of Conservation: New Zealand . (last accessed. 24.03.2017).

Gregerich RJ (2003): A note to researchers: Communicating science to policy makers and practitioners. Journal of Substance Abuse Treatment 25, 233-237.

Guldin G (2003): Forest science and forest policy in the Americas: building bridges to a sustainable future. Forest Policy and Economics 5, 329-337.

Haas PM (1992): Introduction: epistemic communities and international policy coordination. In: International Organization, 46 (1), 1 -35.

Haas PM (2004): When does power listen to truth? A constructivist approach to the policy process. Journal of European Public Policy 11(4), 569-592. 
Habermas J (1992): Faktizität und Geltung. Beiträge zur Diskurstheorie des Rechts und des demokratischen Rechtsstaats. Surrkamp Verlag: Frankfurt am Main.

Habitats Directive (1992): Council Directive 92/43/EEC of 21 May 1992 on the conservation of natural habitats and of wild fauna and flora. Official Journal L 206, 22/07/1992 P. 0007 - 0050 http://eur-lex.europa.eu/legalcontent/EN/TXT/HTML/?uri=CELEX:31992L0043\&from=EN (last accessed: 06.05.2017).

Hagenlocher (2012): Multi-scale Service for Monitoring NATURA 2000 Habitats of European Community Interest. Deliverable 2.1. User Requirements Dossier.

Hagner O, Nilsson M, Reese H, Egberth M, Olsson H (2005): Procedure for classification of forests for CORINE land cover in Sweden. In: Oluic (Ed.) (2005): New Strategies for European Remote Sensing. Millpress: Rotterdam, 523-529.

Hammond J., Keeney RL, Raiffa H, (1999): Smart Choices: A Practical Guide to Making Better Life Decisions. Broadway Books: New York.

Hansen MC, de Fries RS, Townshend JRG, Sohlberg R (2000): Global land cover classification at $1 \mathrm{~km}$ spatial resolution using a classification tree approach. international Journal of Remote Sensing 21 (6-7), 1331-1364.

Hansen MC, Potapov PV, Moore R, Hancher M, Turubanova SA, Tyukavina A, Thau D, Stehman SV, Goetz SJ, Loveland TR, Kommareddy A, Egorov A, Chini L, Justice CO, Townshend JRG (2013): High-Resolution Global Maps of 21st-Century Forest Cover Change. Science 342, 850-853. Data available on-line from: http://earthenginepartners.appspot.com/science-2013-global-forest. (last accessed: 15.04.2018).

Heinrich C (2004): Eckpunkte Novelle des Bundeswaldgesetzes. Bonn: NABUBundesfachausschuss Wald und Wild.

Hellström T (2000): Technoscientific expertise and the significance of policy cultures. Technology in Society 22, 499-512.

Hebert PD, Cywinska A, Ball SL, deWaard JR(2003): Biological identifications through DNA barcodes. Proceedings of the Royal Society of London Series B. 270, 313-321.

Hertin J, Jacob K, Pesch U, Pacchi C (2009): The production and use of knowledge in regulatory impact assessment - An empirical analysis. Forest Policy and Economics 11, 413-421. 
Hickey GM, Innes JL, Kozak RA (2007): Monitoring and information reporting for sustainable forest management: A regional comparison of forestry stakeholder perceptions. Journal of Environmental Management 84, 572-585.

Hickey GM, Innes JL, Kozak RA, Bull GQ, Vertinsky I (2005): Monitoring and Information reporting for sustainable forest management: An international multiple case study analysis. Forest Ecology and Management 209, 237-259.

Hockley WE (2008): The picture superiority effect in associate recognition. Memory \& Cognition 36 (7), 1351-1359.

Hofmann F (2003): Globale Waldpolitik in Deutschland. Eine Untersuchung über die Wirkung internationaler Regime in föderalen Strukturen. Remagen-Oberwinter (Dr. Kessel) Freiburger Schriften zur Forst- und Umweltpolitik 4.

Holbrook AL, Green MC, Krosnick JA (2003): Telephone versus face-to-face interviewing of national probability samples with long questionnaires. Comparisons of respondent satisficing and social desirability response bias. Public Opinion Quarterly 97, 79-125.

Humphreys D (2006): Logjam - Deforestation and the crisis of global governance. Earthscan: London, 190-195.

Humphreys D (2009): Discourse as ideology: Neoliberalism and the limits of international forest policy. Forest Policy and Economics 11, 319-325.

Jamshed S (2014): Qualitative research method-interviewing and observation. Journal of Basic and Clinical Pharmacy 5(4), 87-88.

Janse G (2006): Information search behaviour of European forest policy decision-makers. Forest Policy and Economics 8, 579-592.

Janse G (2008): Communication between forest scientists and forest policy-makers in Europe - A survey on both sides of the science/policy interface. Forest Policy and Economics 10, 183- 194.

Janßen A, Liesbach M, Rogge M, Haverkamp M (2014): Tätigkeitsbericht der Bund-LänderArbeitsgruppe „Forstliche Genressourcen und Forstsaatgutrecht“ Berichtszeitraum 20092013. Bundesanstalt für Landwirtschaft und Ernährung Referat 421: Bonn, pp. 237.

Janzen DH, Hajibabaei M, Burns JM, Hallwachs W, Remigio E, Hebert PDN (2005): Wedding biodiversity inventory of a large and complex Lepidoptera fauna with DNA barcoding. Philosophical Transactions of the Royal Society Series B 360 (1462).

Kändler G (2006): Abschlussbericht zum Vorhaben "Vertiefende Analyse der BWI2-Daten unter den Aspekten Naturnähe und Biodiversität" (BWI2-Biodiversitätsauswertung) Forschungsauftrag 04HS062. 
Kangas A, Maltamo M. (Eds.)(2006):Forest Inventory Methodology and Applications. Springer: Dordrecht, The Netherlands.

Keeney RL, Gregory RS (2005): Selecting Attributes to Measure the Achievement of Objectives. Operations Research 53 (1), 1-11.

Keil M, Bock M, Esch T, Metz A, Nieland S, Pfitzner A (2010): CORINE Land Cover Aktualisierung 2006 für Deutschland. Abschlussbericht. DLR-DFD: Wessling, pp. 55. Keith DA, Rodríguez JP, Rodríguez-Clark KM, Nicholson E, Aapala K, Alonso A, et al. (2013): Scientific foundations for an IUCN Red List of Ecosystems. PLoS ONE 8 (5), e62111. https://doi:org/10.1371/journal.pone.0062111 (last accessed: 15.04.2018). Kensinger EA (2007): Negative Emotion Enhances Memory Accuracy. Behavioral and Neuroimaging Evidence 16(4), 213-218.

Khatri N and Ng HA (2000): The Role of Intuition in Strategic Decision Making. Human Relations 53 (1), 57-86.

Kleinschmit B, Walentowski H, Förster M, Fischer M, Seitz R, Kraft P, Schlutow A, Bock M (2006): Erfassung von Wald-Lebensraumtypen in FFH-Gebieten. Fernerkundung am Taubenberg und im Angelberger Forst. LWF Wissen 51, pp.39.

Kovač M, Bauer A, Ståhl G (2014): Merging National Forest and National Forest Health Inventories to Obtain an Integrated Forest Resource Inventory - Experiences from Bavaria, Slovenia and Sweden. PLoS ONE 9(6): e100157. doi:10.1371/journal.pone.0100157 http://journals.plos.org/plosone/article?id=10.1371/journal.pone.0100157 (last accessed: 19.08.2015)

Kraus D, Bütler R, Krumm F, Lachat T, Larrieu L, Mergner U, Paillet Y, Rydkvist T, Schuck A, Winter S (2016): Catalogue of tree microhabitats - Reference field list. Integrate+ Technical Paper. 16 p.

Kröber H (2001): Natur und Landschaft in Niedersachsen: die Naturdenkmal-Typen.

Niedersächsische Heimatbund (Ed.). Schlütersche: Hannover.

Kroiher F, Müller-Kroehling S, Schmitz F, Sukopp U (2017): Methode zur Erfassung und Bewertung der FFH-Waldlebensraumtypen im Rahmen der dritten Bundeswaldinventur (BWI-2012). Thünen Working Paper 69, pp. 67.

Krott M (1990): Öffentliche Verwaltung im Umweltschutz. Ergebnisse einer behördenorientierten Policy-Analyse am Beispiel Waldschutz. W. Braumüller Verlag: Wien.

Krott M (2005): Forest Policy Analysis. Springer: Dordrecht. 
Krott M (2012): Value and risks of the use of analytical theory in science for forest policy. Forest Policy and Economics 16, 35-42.

Krott M, Bader A, Schusser C, Devkota R, Maryundi A, Giessen L, Aurenhammer H (2014): Actor-centered power: The driving force in decentralized community based forest governance. Forest Policy and Economics 49, 34-42.

Krott M, Bader, A, Schusser, C, Devkota, R, Maryudi, A, Giessen, L, Aurenhammer, H (2013): Actor-centred power: the driving force in decentralised community-based forest governance. Forest Policy and Economics 49, 34-42.

Kühn E, Musche M, Harpke A, Feldmann R, Metzler B, Wiemers M, Hirneisen N, Settele J (2014): Tagfalter-Monitoring Deutschland. Oedippus 27. https://www.ufz.de/tagfaltermonitoring/index.php?de=41769 (last accessed: 02.08.2017).

Laestadius L, Minnemeyer S and Leach A (2012): Assessment of Global Forest Degradation. Washington D.C., World Resource Institute.

Laikre L, Nilsson T, Primmer CR, Ryman N, Allendorf FW (2009): Importance of Genetics in the Interpretation of Favourable Conservation Status. Conservation and Policy 23 (6), 1378-1381.

LANA (2001): Beschlüsse der Arbeitsgemeinschaft "Naturschutz" der Landesumweltministerien (LANA). 81th session. September 2001. Pinneberg. https://www.bfn.de/fileadmin/MDB/documents/030306_lana.pdf (last accessed: 03.04.2018)

Landmäteriet (2017): Digital Aerial Imagery. https://www.lantmateriet.se/en/Maps-andgeographic-information/Aerial-and-satellite-images-/Aerial-Photography/Digitalaflygbilder/ (last accessed: 05.05.2017).

Landratsamtes Rhein - Neckar - Kreis (2010): Merkblatt Kontrollen der Landwirtschaftsverwaltung. https://www.landwirtschaftbw.info/pb/site/lel/get/documents/MLR.LEL/PB5Documents/Irahd/InVeKos\%20Kontrolle.pdf (last accessed 03.04.2018).

Lang S (2012a): MS.Monina. Multi-Scale Service for Monitoring Natura 2000 Habitats of European Community Interest. Deliverable 2.1.

Lang S (2012b): Multi-scale Service for Monitoring NATURA 2000 Habitats of European Community Interest. Deliverable 5.6. Framework for identifying threats and pressures on sensitive sites, from remote sensing derived (change) indicators in the site surroundings. https://data.inbo.be/purews/files/1549034/MS_MONINA_Del5_6_v10.pdf (last accessed: 26.11.2015) 
Larrieu L, Paillet Y, Winter S, Bütler R, Kraus D, Krumm F, Lachat T, Michel A K, Regnery B, Vandekerkhove K (2018): Tree related microhabitats in temperate and Mediterranean European forests: A hierarchical typology for inventory standardization. Ecological Indicators 84. 194-207.

Leadley PW, Krug CB, Alkemade R, Pereira HM, Sumaila UR, Walpole M, Marques A, Newbold T, Teh LSL, van Kolck J, Bellard C, Januchowski-Hartley SR, Mumby PJ (2014): Progress towards the Aichi Biodiversity Targets: An Assessment of Biodiversity Trends, Policy Scenarios and Key Actions. Technical Series 78. Secretariat of the Convention on Biological Diversity: Montreal, Canada, 500 p.

Lindenmayer DB, Margules CR, Botkin DB (2000): Indicators of Biodiversity for

Ecologically Sustainable Forest Management. Conservation Biology 14(4), 941-950.

Lorenz M (1995): International Co-operative Programme on Assessment and Monitoring of Air Pollution Effects on Forests, ICP Forests. Water, Air and Soil Pollution 85 (3). Springer: Dordrecht, pp. 1221.

Lorenz M (1995): International co-operative programme on assessment and monitoring of air pollution effects on forests - ICP Forests. Water Air and Soil Pollution 85(3), 1221-1226. Lorenz M, Brizay A, Deda P, Grennfelt P, Michalak R (2014) Forest Monitoring in Europe and its importance to clean air policies and sustainable forest management. IUFRO World Series 32, 411-421.

Loveland TR, Reed BC, Brown JF, Ohlen DO, Zhu Z, Yang L and Merchant JW (2000): Development of a global land cover characteristics database and IGBP DISCover from 1 km AVHRR data, International Journal of Remote Sensing, 21 (6-7), 1303-1330.

Ludwig G, Haupt H, Gruttke H, Binot-Hafke M (2009): Methodik der Gefährdungsanalyse für Rote Listen. In: Rote Liste gefährdeter Tiere, Pflanzen und Pilze Deutschlands. Band 1: Wirbeltiere. Münster (Landwirtschaftsverlag). Naturschutz und Biologische Vielfalt 70 (1), 19-71.

LWF (2007): Anweisung für die FFH-Inventur. Anleitung zum praktischen Vorgehen (in Ergänzung zur Arbeitsanweisung). Version 1.2.

MA (2005). Millennium ecosystem assessment. Ecosystems and human wellbeing: Synthesis. Washington, DC: Island Press.

Maes J (2013): A model for the assessment of habitat conservation status in the EU. JRC Scientific and Policy Reports. Publications Office of the European Union: Luxembourg. Mac Sharry B (2012): User Manual for Range Tool for Article 12 (Birds Directive) \& Article 17 (Habitats Directive). EEA- European Topic Centre on Biological Diversity (ETC/BD). 
http://bd.eionet.europa.eu/activities/Reporting_Tool/Documents/Range_Tool_User_Manu al_18092012.pdf. (last accessed: 19.08.2015).

Marcot BG, Thompson MP, Runge MC, Thompson FR, McNulty S, Cleaves D, Tomosy M, Fisher LA, Bliss A (2012): Recent advances in applying decision science to managing national forests. Forest Ecology and Mangement 285, 123-132.

Matthews E (1982): Global Vegetation and Land Use: New High-Resolution Data Bases for Climate Studies. Journal of Climate and Applied Meteorology 22, 474 - 487.

Mattli W and Slaughter AM (1995): Law and politics in the European Union: a reply to Garrett. International Organisation, Vol. 49, Issue 1, pp. 183-190 http://journals.cambridge.org/abstract_S0020818300001624(last accessed 27 March, 2014).

McCoy ED (1992): Advocacy as part of conservation biology. Conservation Biology 10 (3), 919-920.

McKinley DC, Briggs RD, Bartuska AM (2013): Reprint of: When peer reviewed publications are not enough! Delivering science for natural resource management. Forest Policy and Economics 37, 9-19.

MCPFE (1990): Resolution S1, European Network of Permanent Sample Plots for Monitoring of Forest Ecosystem. Signed at the Ministerial Conference for the Protection of Forests in Europe, 18 December 1990, Strasbourg/France.

MCPFE (2001): Criteria and indicators for Sustainable Forest Management of the MCPFE. International Expert Meeting on Monitoring Assessment and Reporting on the Progress towards Sustainable Forest Management. 5-8 November 2001, Yokohama, Japan.

Mecklenburg W (2005): Die Berichtspflicht aus der Sicht der Naturschutzverbände. Rechtlicher Teil. In: Haak A, Kurz H, Brandt I (2005): Die Monitoringpflicht für europäische Schutzgebiete des Netzes NATURA 2000. VSÖ-Publikationen 6. ad fontes verlag: Hamburg.

Mendoza GA, Martins H (2006): Multi-criteria decision analysis in natural resource management: A critical review of methods and new modelling paradigms. Forest Ecology and Management 230 (1-4), 1-22.

Michel A and Seidling W (Eds.) (2016) Forest Condition in Europe: 2016 Technical Report of ICP Forests. Report under the UNECE Convention on Long-Range Transboundary Air Pollution (CLRTAP). BFW-Dokumentation 23/2016. Vienna: BFW Austrian Research Centre for Forests, pp. 206. 
Michel A, Seidling W, Lorenz M, Becher G, (Eds.) (2014): Forest Condition in Europe 2013 Technical Report of ICP Forests. Report under UNECE Convention on Long-Range Transboundary Air Pollution (CLRTAP). Thünen Working Paper 19, pp. 134.

Millennium Ecosystem Assessment (2005): Ecosystems and HumanWell-being: Synthesis. Island Press: Washington, DC, USA.

Mills TJ, Clark RN (2001): Roles of research scientists in natural resource decision-making. Forest Ecology and Mangement 153, 189-198.

Moore JL, Runge MC (2012): Combining Structured Decision Making and Value-ofInformation Analyses to identify Robust Management Strategies. Conservation Biology $26(5), 810-820$.

Mora B, Herold M, de Sy V, Wijaya A, Verchot L, Penman J (2012): Capacity development in national forest monitoring: Experiences and progress for REDD+. Joint report by CIFOR and GOFC-GOLD. Bogor, Indonesia.

Mrosek T, Kies U, Schulte A (2005): Clusterstudie Forst und Holz Deutschland 2005. Forstund Holzwirtschaft hat sehr große volkswirtschaftliche und arbeitsmarktpolitische Bedeutung. Holz-Zentralblatt (84).

Mrosovsky N (1997): IUCN's credibility critically endangered. Nature 389, 436 pp. Müller-Kroehling S (2016): FFH-Managementpläne im Wald. Schlüssigkeit der Landesverfahren wichtiger als bundesweite Einheitlichkeit. Naturschutz und Landschaftsplanung 43(6), 190-191.

NeFo (2017): Ohne Nachweis des Ausmaßes der Verluste wird man keine politische Aufmerksamkeit erreichen. Interview with Horst Wägele on 18.12.2017. NetzwerkForum zur Biodiversitätsforschung Deutschland.

http://www.biodiversity.de/produkte/interviews/nationales-biodiversitatsmonitoring (last accessed: 15.04.2018).

Newson SE, Woodburn RJW , Noble DG, Baillie SR, Gregory RD (2005) Evaluating the Breeding Bird Survey for producing national population size and density estimates, Bird Study, 52 (1), 42-54, DOI: 10.1080/00063650509461373.

Newton AC, Kapos V (2003): Biodiversity indicators in national forest inventories. Background paper 6.4. presented at: Expert Consultation on Global Forest Resources Assessments - Linking National and International efforts: Kotka, Finland 1-5 July 2002. Niemeijer D, de Groot R (2008): A conceptual framework for selecting environmental indicator sets. Ecological Indicators 8, 14-25. 
Niskanen W (1971): Bureaucracy and Representative Government. Aldine-Atherton:

Chicago.

Noss R (1990): Indicators for Monitoring biodiversity: A Hierarchical Approach.

Conservation Biology 4(4), 355-364.

O'Brien MH (1993): The professional biologist: being a scientist means taking sides.

BioScience 43 (10), 706-708.

OECD / Organisation for Economic Co-operation and Development (1993): OECD Core Set of Indicators for Environmental Performance Reviews. A Synthesis Report by the Group on the State of the Environment. OCDE/GD(93)179. OECD environment monographs 83: Paris, $35 \mathrm{pp}$.

Opdenakker R (2006): Advantages and Disadvantages of Four Interview Techniques in Qualitative Research. Forum Qualitative Sozialforschung / Forum Qualitative Social Research 7(4) http://nbn-resolving.de/urn:nbn:de:0114-fqs0604118 (last accessed: 20.12.2017).

Pawlaczyk P, Kepel A, Jaros R, Dzięciołowski R, Wylegała P, Szubert A, Sidło P O (2004): Natura 2000 Shadow List in Poland. Detailed Analysis of Habitat Directive Implementation Synthetic Approach to Bird Directive Implementation. WWF: Warsaw. Penman J, Gytarsky M, Hiraishi T, Krug T, Kruger D, Pipatti R, Buendia L, Miwa K, Ngara T, Tanabe K, Wagner F (2003): Good practice guidance for land use, land-use change and forestry. Institute for Global Environmental Strategies (IGES) for the IPCC: Japan. ISBN 4-88788-003-0. http://www.ipcc-

nggip.iges.or.jp/public/gpglulucf/gpglulucf_files/GPG_LULUCF_FULL.pdf (last accessed: 19.08.2015).

Peters BG (2010): The Politics of Bureaucracy - An Introduction to Comparative Public Administration. 6th ed, Routledge: Oxon.

Phelps EA (2004): Human emotion and memory: interactions of the amygdala and hippocampal complex. Current Opinion in Neurobiology 14 (2), 198-202.

Pielke Jr. RA (2002): Science policy: Policy, politics and perspective. Nature 416: 367-368 https://www.nature.com/nature/journal/v416/n6879/full/416367a.html (last accessed: 15.04.2018)

Pielke Jr RA (2005): Misdefining "climate change": consequences for science and action. Environmental Science \& Policy 8 (i), 548-561.

Pielke Jr RA (2004): When scientists politicize science: making sense of controversy over The Skeptical Environmentalist. Environmental Science \& Policy 7, 405-417. 
Pielke Jr RA (2007): The Honest Broker. Making Sense of Science in Policy and Politics. Cambridge University Press.

Pommerening A, Vítková L, Zhao X, Pallarés Ramos C. (2015): Towards Understanding Human Tree Selection Behaviour. Fakta. Skog 9. Faculty of Forest Sciences, Swedish University of Agricultural Sciences: Umeå.

Possingham HP, Andelman SJ, Burgman MA, Medellín RA, Master LL, Keith DA (2002): Limits to the use of threatened species lists. Trends in Ecology and Evolution 17 (11), 503-507.

Pregernig M (2007): Zwischen Alibi und Aushandlung: Ein empirischer Blick auf die Interaktion zwischen Wissenschaft und Politik am Beispiel der österreichischen Umweltund Ressourcenpolitik. In: Krott, M, Suda, M. (Eds.): Macht Wissenschaft Politik? VS Verlag für Sozialwissenschaften: Wiesbaden, 43-79.

Pülzl H (2010): Die Politik des Waldes. Böhlau Verlag: Vienna.

Ranneby B, Crusee H, Hägglund B, Jonasson H, Sward J (1987): Designing a new national forest survey for Sweden. Studia Forstalia Suecica 177: Uppsala.

Raustialia K (1997): Domestic Institutions and international Regulatory Cooperation.

Comparative Responses to the Convention on Biological Diversity. World Politics 49 (4), 482-509.

Rayner J, Buck A, Katila P (2010) Eds: Embracing Complexity: Meeting the challenges of international forest governance. IUFRO World Series 28: Vienna, 172.

Rees G, Pond K (1995): Marine Litter Monitoring Programmes: A Review of Methods with Special Reference to national Survey. Marine Pollution Bulletin 30, 103-108.

Reese H, Granqvist-Pahlén T, Egberth M, Nilsson M, Olsson H (2005): Automated estimation of forest parameters for Sweden using Landsat data and the kNN algorithm. Proceedings of the 31st International Symposium on Remote Sensing. June 20-24, 2005. St.

Petersburg, Russia. http://www.isprs.org/proceedings/2005/ISRSE/html/papers/652.pdf. (Last accessed: October 2017).

Reif A, Wagner U, Bieling C (2005): Analyse und Diskussion der Erhebungsmethoden und Ergebnisse der zweiten Bundeswaldinventur vor dem Hintergrund ihrer ökologischen und naturschutzfachlichen Interpretierbarkeit. BfN-Skripten 158: Bonn, pp. 45.

Reif A, Walentowski H (2008): The assessment of naturalness and its role for nature conservation and forestry in Europe. Waldökologie, Landschaftsforschung und Naturschutz 6, 63-76. 
Reise J, Henneberg K, Winter S, Winter C, Höltermann A. (2017): Analyse und Diskussion naturschutzfachlich bedeutsamer Ergebnisse der dritten Bundeswaldinventur. BfN Skripten 427. BMU-Druckerei: Bonn, Bad Godesberg.

Requardt A (2007): Pan-European Criteria and Indicators for Sustainable Forest Management: Networking Structures and Data Potentials of International Data Sources. Dissertation thesis. University of Hamburg.

Ribot JC (1999): Decentralisation, participation and accountability in sahelian forestry: Legal instruments of political-administrative control. Africa 69 (1), 23-65 http://www.jstor.org/stable/1161076 (accessed 27 March, 2014).

Rieken U, Ries U, Ssymank A (1994): Rote Liste der gefährdeten Biotoptypen der Bundesrepublik Deutschland. Schriftreihe für Landschaftspflege und Naturschutz 41. pp. 184.

Riecken U, Finck P, Raths U, Schröder E, Ssymank A (2006): Rote Liste der gefährdeten Biotoptypen Deutschlands. Zweite fortgeschriebene Fassung 2006. Naturschutz und Biologische Vielfalt 34, pp. 318.

Risse T (2004): Global governance and communicative action. Government and Opposition 39 (2), 288-313.

Rodrigues ASL, Pilgrim JD, Lamoreux JF, Hoffmann M, Brooks TM (2006): The value of the IUCN Red List for conservation. TRENDS in Ecology and Evolution 21 (2), 71-76. Rodriguez JP, Keith DA., Rodriguez-Clark KM, Murray NL, Nicholson E, Regan TJ, Miller RM, Barrow EG, Bland LM, Boe K, Brooks TM, Oliveira-Miranda MA, Spalding M, Wit P (2015): A practical guide to the application of the IUCN Red List of Ecosystems criteria. Phil. Trans. R. Soc. B 370: 20140003. http://dx.doi.org/10.1098/rstb.2014.0003 (last accessed: 15.04.2018).

Rondeux J, Sanchez C (2010): Review of indicators and field methods for monitoring biodiversity within national forest inventories. Core variable: Deadwood. Environmental Monitoring and Assessment 164, 617-630.

Rosenkranz L, Wippel B, Seintsch B (2012): FFH-Impact: Teil 1: Umsetung der FFHRichtlinie im Wald in den Bundesländern. Work Report. vTI: Bonn. Ruehl J (2016): Aufbau eines Pilotdienstes Natura 2000-Monitoring NRW zur Einbindung Copernicus-basierter Natura 2000-Monitoringdienste in die Naturschutz-verwaltungen der Bundesländer. LANUV. http://www.dcopernicus.de/fileadmin/Content/pdf/Beispiele-aus-Deutschland/umweltnaturschutz/NATURA2000_3.03.16_DE.pdf (last accessed: 15.04.2018). 
Runge MC, Converse S J, Lyons JE (2011): Which uncertainty? Using expert elicitation and expected value of information to design an adaptive program. Biological Conservation 144, 1214-1223.

Sabatier PA (1988): An advocacy coalition framework of policy change and the role of policy-oriented learning therein. Policy Sciences 21, pp. 129.

Sachteleben J, Behrens M (2010a): Konzept zum Monitoring des Erhaltungszustandes von Lebensraumtypen und Arten der FFH-Richtlinie in Deutschland. BfN-Skripten 278. BMU-Druckerei: Bonn, Bad Godesberg.

Sachteleben J, Fartmann T, Neukirchen M, Weddeling K (2010b): Bewertung des Erhaltungszustandes der Lebensraumtypen nach Anhang I der Fauna-Flora-HabitatRichtlinie in Deutschland Überarbeitete Bewertungsbögen der Bund-Länder-Arbeitkreise als Grundlage für ein bundesweites FFH-Monitoring. Im Auftrag des Bundesamtes für Naturschutz - FKZ 80582 013. PAN/ILÖK: München.

Sanders TGM, Michel AK, Ferretti M (2016): 30 years of monitoring the effects of longrange transboundary air pollution on forests in Europe and beyond. UNECE/ICP Forests: Eberswalde, pp. 67.

Sarewitz D (2010): Politicize me: Barack Obama is finding that sometimes politics needs to put science in its place. Nature 467, 26. https://www.nature.com/news/2010/100902/full/467026a.html (last accessed: 15.04.2018)

Sarewitz D, Pielke Jr RA (2017): The neglected heart of science policy: reconciling supply of and demand for science. Environmental Science \& Policy.

Sayegh L, Anthony WP, Perrewé L (2004): Managerial decision-making under crisis: The role of emotion in an intuitive decision process. Human Resource Management Review $14,179-99$.

Schmitz F (2013): Bund-Länder-Sitzung Bundeswaldinventur 2012 Testrechnungen zum Zustand. Ergebnisprotokoll. 9.-12.9.2013, Freising https://bundeswaldinventur.de/fileadmin/SITE_MASTER/content/BWI_intern/Prot_B-LBWI_2013_09_mitAnl.pdf (accessed: 15.04.2018).

Schmitz F (2015): Personal communication on 24.02.2015 at BMEL, Bonn.

Schuck A, Krumm F, Kraus D (2015): Integrate+ Marteloscopes - Description of parameters and assessment procedures. Integrate+ Technical Paper 18, 16.

Scott P, Burton JA, Fitter R (1987): Red data books: the historical background. In: Fitter R, Fitter M (Eds) The road to extinction. IUCN: Gland, 1-5. 
Seiler U (2012): Informationspotentiale historischer Forsteinrichtungskarten - eine umfangreiche Datenqueslle zum Nutzungswamdel in den Wäldern? In: Anders U, Szücs L (2012): Landnutzungswandel in Mitteleuropa, Forschungsgegenstand und methodische Annäherung an die historische Landschaftsanalyse. Universitätsverlag Göttingen: Göttingen, 117-130.

Shannon MA, Meidinger EE, Clark RN (1996): Proceedings of the Society of American Foresters (1996): SUNY Buffalo Legal Studies Research Paper No. 1996-1100. https://ssrn.com/abstract=2477062 (last accessed: 15.06 .2017 )

Siry JP, Cubbage FW, Ahmed MR (2005): Sustainable forest management: global trends and opportunities. Forest policy and Economics 7, 551-561.

Slaughter AM (1995): International Law in a World of Liberal States. 6 EJIL, 503-538.

SLU (2015a): Markinventeringen - Swedish Forest Soil Inventory. http://www.slu.se/en/collaborative-centres-and-projects/swedish-forest-soilinventory/(last accessed: 19.08.2015)

SLU (2015b):MOTH, more and better knowledge of less common habitats - a LIFE+ project. Layman's report. https://www.slu.se/en/Collaborative-Centres-andProjects/moth/publications/(last accessed: 19.08.2015)

SLU (2017): Publications. http://www.slu.se/en/departments/forest-biomaterialstechnology/research/publications/ (last accessed, 17.05.2017).

Smeets E, Weterings R (1999): Environmental indicators: Typology and overview. Technical report 25. EEA: Copenhangen. https://www.eea.europa.eu/publications/TEC25 (last accessed: 15.04.2018)

Spreen M (1992): Rare populations, hidden populations and link-tracing designs: what and why?. Bulletin Methodologie Sociologique 36, 34-58.

SRU (2000): Umweltgutachten 2000. Schritte ins nächste Jahrtausend. Unterrichtung durch die Bundesregierung. Drucksache 14/3363 (14.03.2000) Metzler-Poeschel: Stuttgart, pp. 688.

SRU (2008): Umweltgutachten 2008. Umweltschutz im Zeichen des Klimawandels. Erich Schmidt Verlag: Berlin

Ssymank A, Rieken U, Ries U (1993): Das Problem eines Bezugssystems für eine Rote Liste Biotope - Standard-Biotoptypenverzeichnis, betrachtungsebenen, Differenzierungsgrad und Berücksichtigung regionaler Gegebenheiten. Schriftreihe für Landschaftspflege und Naturschutz 38, 47-58. 
Ssymank A, Hauke U, Rückriem C, Schröder E, Messer D (1998): Das europäische Schutzgebietssystem Natura 2000. BfN-Handbuch zur Umsetzung der Fauna-FloraHabitat-Richtlinie und der Vogelschutz-Richtlinie. Schriftreihe für Landschaftspflege und Naturschutz 53, pp. 560.

Sollmann R, Gardner B, Williams KA, Gilbert AT, Veit RR (2016): A hierarchical distance sampling model to estimate abundance and covariate associations of species and communities. Methods in Ecology and Evolution 7 (5), 529-537.

Ståhl G, Allard A, Esseen PA, Glimskär A., Ringvall A, Svensson J, Sundquist S, Christensen P, Gallegos Torell Å, Högström M, Lagerqvist K, Marklund L, Nilsson B, Inghe O (2011): National Inventory of Landscapes in Sweden (NILS) - Scope, design, and experiences from establishing a multiscale biodiversity monitoring system. Environmental Monitoring and Assessment 173, 379-595.

Stevanov M, Böcher M, Krott M, Krajter S, Vuletic D, Orlovic S (2013): The Research, Integration and Utilization (RIU) model as an analytical framework for the professionalization of departmental research organizations: Case studies of publicly funded forest research institutes in Serbia and Croatia. Forest Policy and Economics 37, 20-28.

Strogies M and Gniffke P (Eds.) (2014): Nationaler Inventarbericht Deutschland - 2014. Umweltbundesamt: Dessau, pp.964.

Suda M and Goodwin B (2008): Science-Policy interface: what do scientists think of others and how others relate to scientists; communication between scientists and policy makers; social science and forest policy interface. In: Pülzl (2008): Forest governance and the role of forestry research. Proceedings. EC/FTP Workshop Kranjska Gora, Slovenia 19-21 May 2008, 16-19.

Swedish Environment Protection Agency (naturvardsverket) (2013): Report on the main results of the surveillance under article 11 for Annex I habitat types (Annex D). http://cdr.eionet.europa.eu/Converters/run_conversion?file=se/eu/art17/envucgywg/SE_h abitats_reports-131223-141035.xml\&conv=350\&source=remote\#9010 (last accessed: 19.08.2015)

TEEB (2010): TEEB - the economics of ecosystems and biodiversity: Ecological and economic foundations. Kumar P (Ed.). London: Earthscan.

Ten Brink B (2003): Indicators as communication tools: an evolution towards composite indicators. Project no. GOCE-CT-2003-505298. ALTER-Net (A Long-term Biodiversity, Ecosystem and Awareness Research Network). 
Ten Brink B, Condé S, Schuryser F (2010): Interlinkages between the European biodiversity indicators, improving their informative power. Report of the working group on Interlinkages of the Streamlining European Biodiversity Indicators project (SEBI), European Environment Agency: Copenhangen, pp. 59.

Thomas DE (1996): Report on the European Union's forestry strategy. Committee on Agriculture and Rural Development. European Parliament. http://www.europarl.europa.eu/sides/getDoc.do;jsessionid=D724DD1A7AA33D482F98F 3B1F95A97BC.node2?pubRef=-//EP//TEXT+REPORT+A4-19960414+0+DOC+XML+V0//EN\&language $=\mathrm{EN}$ (last accessed on 29.03.2017)

Thoroe C, Dieter M, Elsasser P, Englert H, Küppers JG, Roering HW (2003): Untersuchungen zu den ökonomischen Implikationen einer Präzisierung der Vorschriften zur nachhaltigen, ordnungsgemäßen Forstwirtschaft bzw. von Vorschlägen zur Konkretisierung der Guten fachlichen Praxis in der Forstwirtschaft. Arbeitsbericht Institut für Ökonomie. Bundesforschungsanstalt für Forst- und Holzwirtschaft: Hamburg.

Thurich E (2011): pocket politik. Demokratie in Deutschland, 4th ed. Bundeszentrale für politische Bildung: Bonn.

TI (2014): Dritte Bundeswaldinventur 2012. Ergebnisdatenbank. https://bwi.info/start.aspx (last acessed: 2014).

Tulloch AIT, Possingham HP, Joseph LN, Szabo J, Martin TG (2013): Realising the full potential of citizen science monitoring programs. Biological Conservation 165, 128-138.

UBA (2008): Berichterstattung unter der Klimarahmenkonvention der Vereinten Nationen 2008. Nationaler Inventarbericht zum deutschen Treibhausgasinventar 1990 - 2006. http://cdr.eionet.europa.eu/de/eu/ghgmm/envr7hb8w/DE_NIR_2008_Final_German.pdf (last accessed 27 March, 2014).

UBA (2012): Submission under the United Nations Framework Convention on Climate Change and the Kyoto Protocol 2012. National Inventory Report for the German Greenhouse Gas Inventory 1990 - 2010.

http://www.umweltbundesamt.de/publikationen/submission-under-united-nationsframework-1 (last accessed 27 March, 2014).

UN (2016): United Nations Strategic Plan on Forests. Advance version. http://www.un.org/esa/forests/wp-content/uploads/2016/12/UNSPF_AdvUnedited.pdf (last accessed: 08.08.2017)

UNCSD (2012): The Future We Want - Outcome document. A/RES/66/288. Resolution adopted by the General Assembly on 27 July 2012. 
UNECE (2017):Development of the Convention. http://www.unece.org/index.php?id=43545 (last accessed: 17.01.2017).

UNECE ICP Forests Programme Co-ordinating Centre (Ed.) (2016): Manual on methods and criteria for harmonized sampling, assessment, monitoring and analysis of the effects of air pollution on forests. Thünen Institute of Forest Ecosystems: Eberswalde. http://www.icpforests.org/Manual.htm (last accessed: 06.06.2017).

UNESCO (1973): International Classification and Mapping of Vegetation. Ecology and Conservation 6. Paris. http://unesdoc.unesco.org/images/0000/000050/005032MB.pdf (last accessed: 14.07.2018)

United Nations (1992a): Report of the UN Conference on Environment and Development, Rio de Janeiro, 3-14 June 1992, Annex III: Non-Legally Binding Authoritative Statement of Principles for a Global Consensus on the Management, Conservation and Sustainable Development of All Types of Forests. UN Doc. A/CONF.151/26 (Vol. III), 14 August 1992. http://www.un.org/documents/ga/conf151/aconf15126-3annex3.htm (last accessed: 29.06.2017).

United Nations (1992b): Report of the UN Conference on Environment and Development, Rio de Janeiro, 3-14 June 1992, Annex II: Agenda 21, UN Doc. A/CONF.151/26 (Vol. II), 13 August 1992. http://www.un.org/documents/ga/conf151/aconf15126-2.htm (last accessed: 29.06.2017)

United Nations (2018): United Nations Treaty Collection. Glossary. https://treaties.un.org/pages/Overview.aspx?path=overview/glossary/page1_en.xml (last accessed: 27.01.2018).

Urda D, Maxim I (2012a): Specie and Habitat types Range Tool. Gap-filling algorithm. EEA - European Topic Centre on Biological Diversity.

http://bd.eionet.europa.eu/activities/Reporting/Article_17/Reporting_Tool/Reporting_Too 1_Software (last accessed: 19.08.2015).

Urda D, Maxim I (2012b): Specie and Habitat types Range Tool. Parameters. EEA European Topic Centre on Biological Diversity. http://bd.eionet.europa.eu/activities/Reporting/Article_17/Reporting_Tool/Reporting_Too 1_Software(last accessed: 19.08.2015).

Vassen F (2018): Personal communication. by email, 16.04.2018-17.04.2018. van Swaay C, Cuttelod A, Collins S, Maes D, López Munguira M, Šašić M, Settele J,

Verovnik R, Verstrael T, Warren M, Wiemers M, Wynhof I (2010): European Red List of Butterflies. Publications Office of the European Union: Luxembourg. 
von Carlowitz HC (1713): Sylvicultura oeconomica oder haußwirtschaftliche Nachricht und naturgemäße Anweisung zur wilden Baumzucht. Braun: Leipzig (Reprint TU Bergakademie Freiberg 2000).

Wagner S, Jönsson A (2001): Einschränkungen der Waldbewirtschaftung durch Naturschutzauflagen am Beispiel des europäischen Schutzgebietssystems Natura 2000 Rechtsfragen und monetäre Bewertung. AGDW: Augsburg and Göttingen.

Weber N, Christophersen T (2002): The influence of non-governmental organisations on the creation of Natura 2000 during the European Policy process. Forest Policy and Economics 4, 1-12.

Webb GJW (2008): The dilemma of accuracy in IUCN Red List categories, as exemplified by hawksbill turtles Eretmochelys imbricata. Endangered Species Research 6, 161-172.

Weible C (2007): An Advocacy Coalition Framework Approach to Stakeholder Analysis: Understanding the Political Context of California Marine Protected Area Policy.” Journal of Public Administration Research and Theory 17(1), 95-117.

Weingart P (1982): The Scientific Power Elite - A Chimera: The Deinstitutionalization and Politicization of Science. In: Elias N, Martins H, Whitley R (Eds.): Scientific Establishments and Hierarchies. Sociology of the Sciences a Yearbook 6. Reidel: Dordrecht, 71-87.

Wellbrock N, Aydin CT, Block J, Bussian B, Deckert M, Diekmann O, Evers J, Fetzer KD, Gauer J, Gehrmann J, Kölling C, König N, Liesebach M, Martin J, Meiwes KJ, Milbert G, Raben G, Riek W, Schäffer W, Wolff B, et al. (2006): Bodenzustandserhebung im Wald (BZE II), Arbeitsanleitung für die Außenaufnahmen. Bundesministerium für Ernährung, Landwirtschaft und Verbraucherschutz: Bonn, pp. 431.

Winkel G, Gleißner J, Pistorius T, Sotirov M, Storch S (2011): The sustainably managed forest heats up: discursive struggles over forest management and climate change in Germany. Critical Policy Studies 5 (4), 361-390.

Winkel G, Volz KR (2003): Naturschutz und Forstwirtschaft, Kriterienkatalog zur Bewertung der Guten fachlichen Praxis. Angewandte Landschaftsökologie 52.

Landwirtschaftsverlag: Münster-Hiltrup, pp. 187 and Annex 9.

Wolfslehner B, Vacik H. (2011): Mapping indicator models: From intuitive problem structuring to qualified decision-making in sustainable forest management. Ecological Indicators 11 (2), 274-283.

WTO (1998): Environmental Services. Background Note by the Secretariat. S/C/W/46. 